Prepared in cooperation with the University of California at Davis and CALFED Drinking Water Quality Program

\title{
Groundwater Contributions of Flow, Nitrate, and Dissolved Organic Carbon to the Lower San Joaquin River, California, 2006-08
}

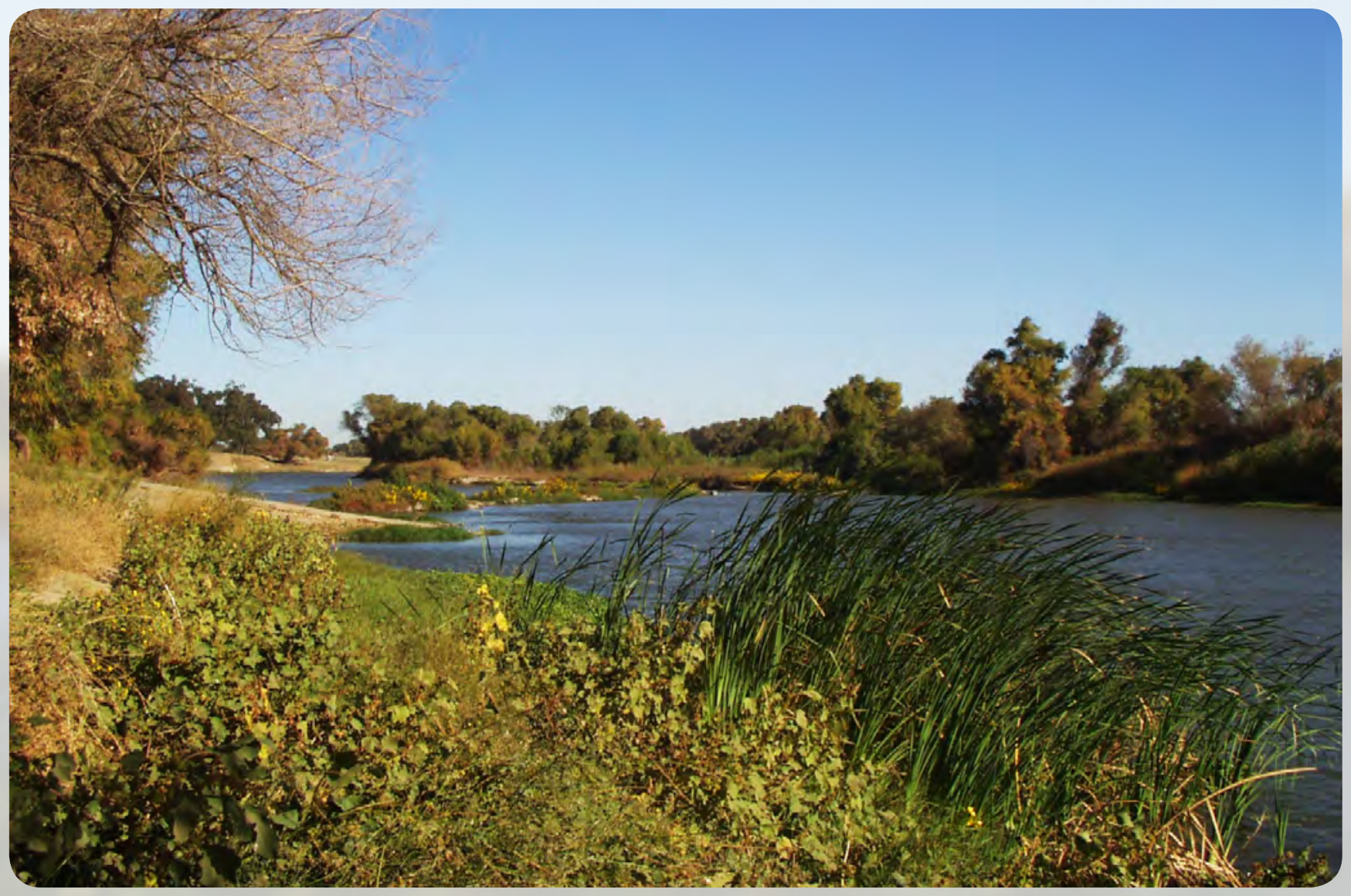

Scientific Investigations Report 2013-5151 
Cover: Photograph of the San Joaquin River taken by Aquafornia, Water Education Foundation. 


\section{Groundwater Contributions of Flow, Nitrate, and Dissolved Organic Carbon to the Lower San Joaquin River, California, 2006-08}

By Celia Zamora, Randy A. Dahlgren, Charles R. Kratzer, Bryan D. Downing, Ann D. Russell, Peter D. Dileanis, Brian A. Bergamaschi, and Steven P. Phillips

Prepared in Cooperation with the University of California at Davis and CALFED Drinking Water Quality Program

Scientific Investigations Report 2013-5151 


\title{
U.S. Department of the Interior SALLY JEWELL, Secretary
}

\section{U.S. Geological Survey Suzette M. Kimball, Acting Director}

\author{
U.S. Geological Survey, Reston, Virginia: 2013
}

For more information on the USGS - the Federal source for science about the Earth, its natural and living resources, natural hazards, and the environment, visit http://www.usgs.gov or call 1-888-ASK-USGS.

For an overview of USGS information products, including maps, imagery, and publications, visit http://www.usgs.gov/pubprod

To order this and other USGS information products, visit http://store.usgs.gov

Any use of trade, firm, or product names is for descriptive purposes only and does not imply endorsement by the U.S. Government.

Although this information product, for the most part, is in the public domain, it also may contain copyrighted materials as noted in the text. Permission to reproduce copyrighted items must be secured from the copyright owner.

Suggested citation:

Zamora, Celia, Dahlgren, R.A., Kratzer, C.R., Downing, B.D., Russell, A.D., Dileanis, P.D., Bergamaschi, B.A., and Phillips, S.P., 2013, Groundwater contributions of flow, nitrate, and dissolved organic carbon to the lower San Joaquin River, California, 2006-08, U.S. Geological Survey Scientific Investigations Report 2013-5151, 105 p. 


\section{Contents}

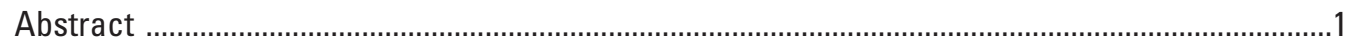

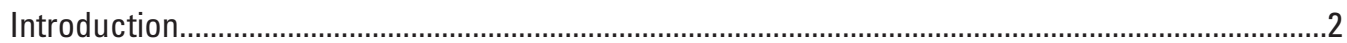

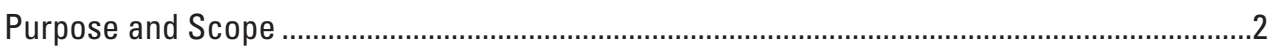

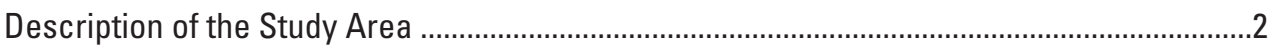

Physiography and Geology .....................................................................................

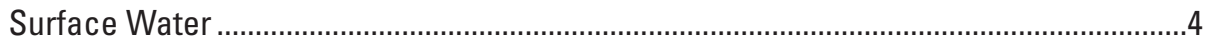

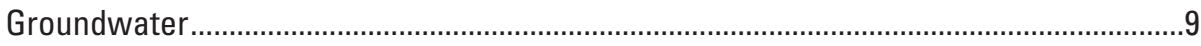

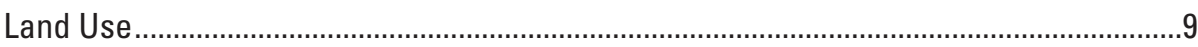

Hydrologic Conditions during the Study Period....................................................................11

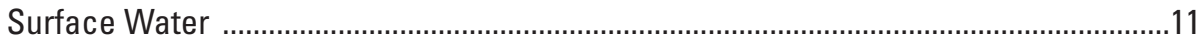

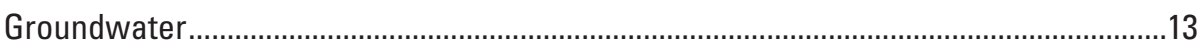

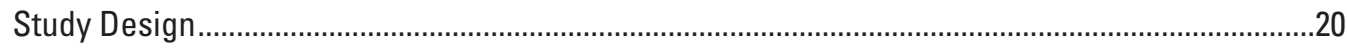

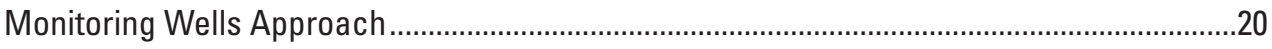

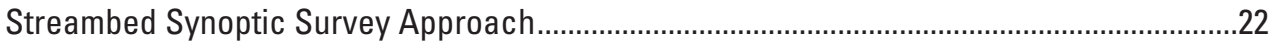

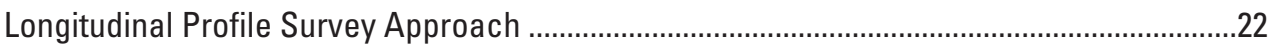

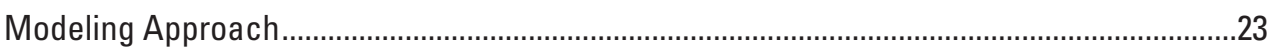

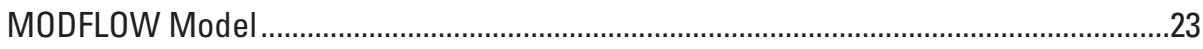

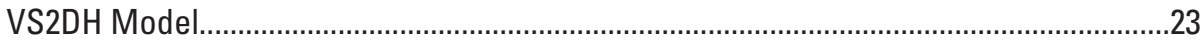

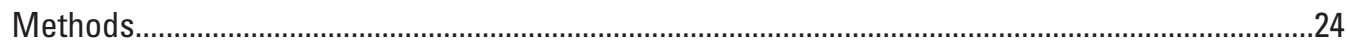

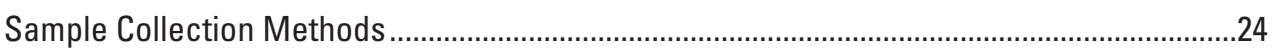

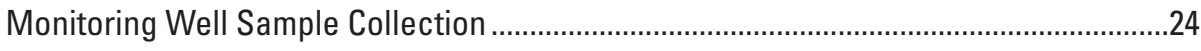

Streambed Synoptic Survey Sample Collection ................................................................25

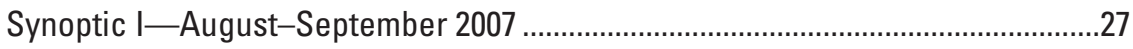

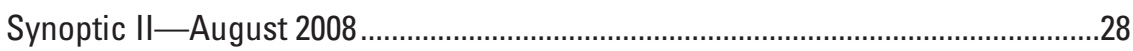

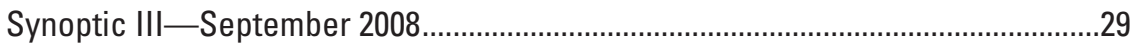

Synoptic IV—June 2009 ......................................................................................

Longitudinal Profile Survey Sample Collection.................................................................

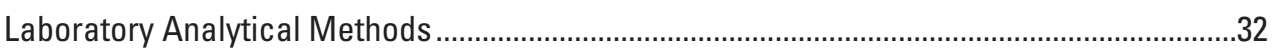

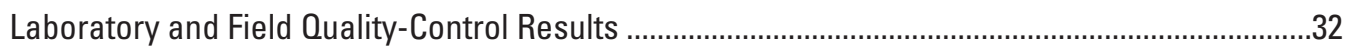

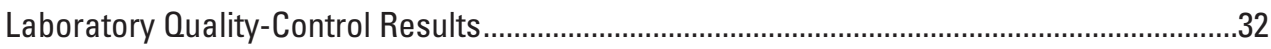

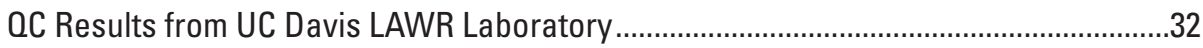

QC Results from USGS Sacramento Organic Carbon Laboratory ......................................33

Field Quality-Control Results...............................................................................................33

Groundwater Interactions with the San Joaquin River.............................................................33

Groundwater Flux by Differences in Surface-Water Flows and Diversions............................33

August 2006-December 2007 ...................................................................................

August 15-September 7, 2007 .............................................................................

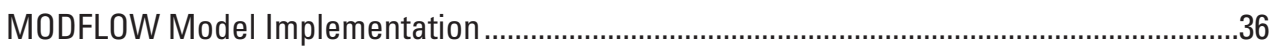

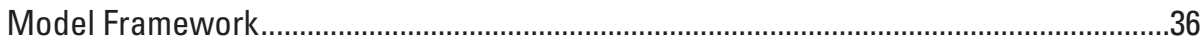

Calibration and Sensitivity Analysis ...............................................................................37

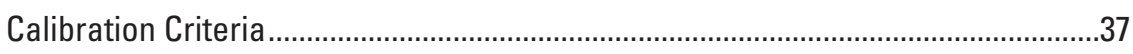

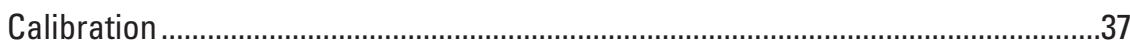




\section{Contents-Continued}

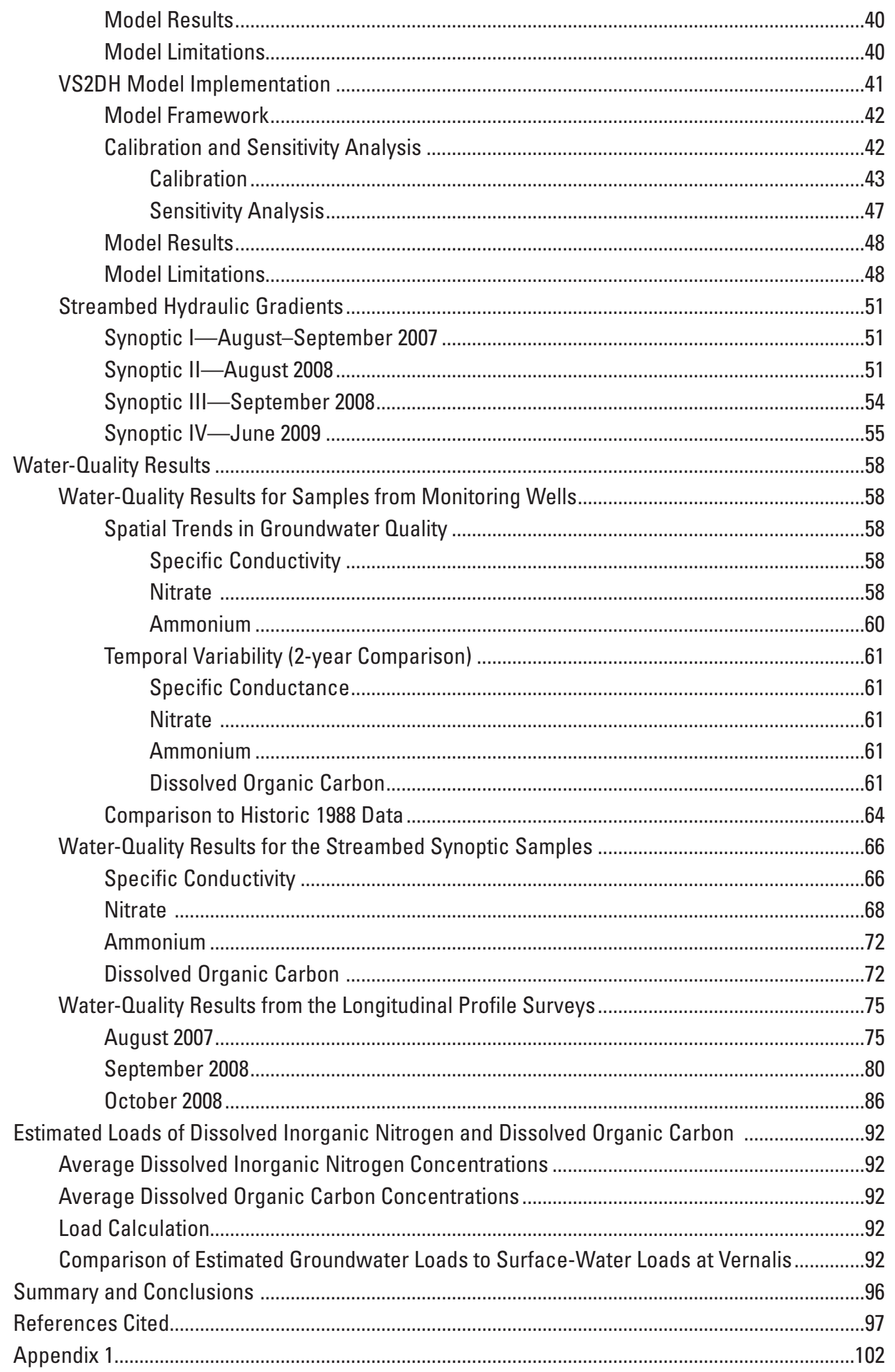




\section{Contents-Continued}

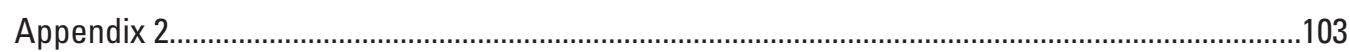

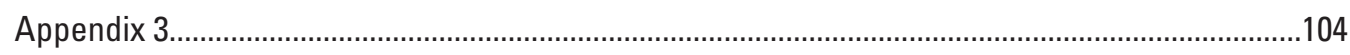

Appendix 4 105

Appendix 5

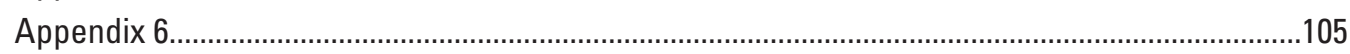

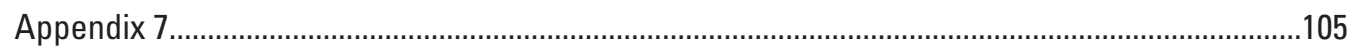

Appendix 8

\section{Figures}

1. Map showing perennial San Joaquin Basin and major waterways ....................................3

2. Map showing physiographic provinces of California within the lower San Joaquin

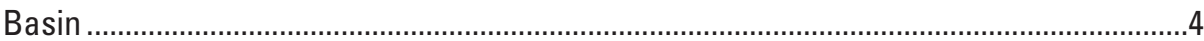

3. Maps showing distribution of mean annual precipitation (1980-97) for the lower

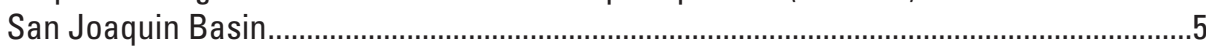

4. Graph showing water-year index and hydrologic classification for 1901-2009 for

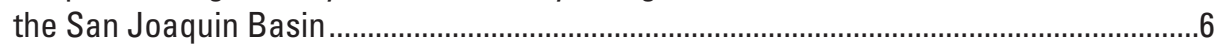

5. Map showing diversion points for agricultural use in the San Joaquin Valley..................7

6. Maps showing discharge points of agricultural return flow in the San Joaquin

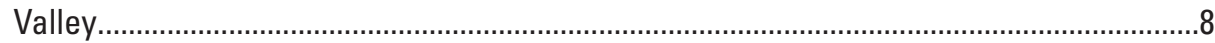

7. Map showing land use in San Joaquin Basin.............................................................10

8. Graphs showing mean daily flow in the San Joaquin River for the 2006-09 water years compared to long-term average of the mean daily flow for the 1975-2009 water years at the most upstream site: San Joaquin River at Newman and the most downstream site: San Joaquin Valley at Vernalis

9. Map showing water table altitude to the east and west of the monitoring well locations, spring 2006.

10. Graphs showing water levels of bank wells at each cluster site at Newman, Crows Landing, and Patterson

11. Graphs showing horizontal hydraulic gradients between shallow bank wells and the San Joaquin River at the Newman, Crows Landing, and Patterson sites

12. Graphs showing vertical hydraulic gradients between deep and shallow bank wells at the Newman, Crows Landing, and Patterson sites.

13. Graph showing horizontal hydraulic gradients between deep bank wells on opposite sides of the San Joaquin River

14. Graphs showing median water levels in the bank wells for the 1988-89 and 2006-08 study periods: Newman site, Crows Landing site, and Patterson site

15. Map and images showing well cluster sites at six locations along the San Joaquin River.

16. Images showing conceptual mode of scenarios of gaining stream, losing stream, and neutral stream that occur during surface-water and groundwater exchanges

17. Photographs showing in-stream well at the San Joaquin River at Orchard Road site before installation, after installation, and the data logging equipment and water-quality sampling tubing housed in the instrumentation shelter

18. Photographs showing water-quality sampling of a bank well and an in-stream well. 


\section{Figures-Continued}

19. Photographs showing measurement of hydraulic gradient made by using a manometer board and the various equipment used to collect samples during the streambed synoptic surveys.

20. Map showing sites sampled during Synoptic I, August-September 2007......................27

21. Map showing sites sampled during Synoptic II, August 2008 .........................................28

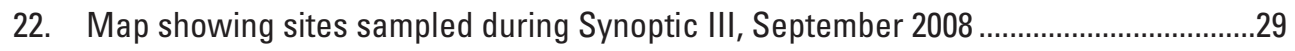

23. Map showing sites sampled during Synoptic IV, June 2009 ..........................................30

24. Photograph showing watercraft used to tow and house instrumentation used for the collection of continuous longitudinal water-quality data

25. Graph showing mean daily flow of surface-water inputs and diversions for the San Joaquin River upstream of Vernalis (August 1, 2006-December 31, 2007) in Vernalis time.

26. Graph showing mean daily flow of surface-water inputs and diversions for the San Joaquin River upstream of Vernalis (August 15-September 7, 2007) in Vernalis time

27. Graph showing dimensions and discretization of the MODFLOW model grid and specifications of boundary conditions

28. Schematics showing median water levels in bank wells relative to median stream stage for the 2007-09 and historic (1988-89) modeled periods: Newman site, Crows Landing site, and Patterson site

29. Schematics showing summary of calibration results from MODFLOW for the Newman site, and Crows Landing site

30. Schematics showing streambed temperature profiles for a neutral stream, a gaining stream, and a losing stream reach.

31. Schematic showing framework for one-dimensional vertical modeling of water and heat flow through a streambed used in the VS2DH model.....

32. Graphs showing VS2DH modeling results for the Newman site, including simulated temperatures, measures of bias, and associated root mean-square error for observed temperatures at 0.5 foot below the streambed, 1.0 foot below the streambed, 1.5 feet below the streambed, and 3.0 feet below the streambed

33. Graphs showing VS2DH modeling results for the Crows Landing site, including simulated temperatures, measures of bias, and associated root mean-square error for observed temperatures at 0.5 foot below the streambed, 1.0 feet below the streambed, 1.5 feet below the streambed, and 3.0 feet below the streambed

34. Graphs showing VS2DH modeling results for the Vernalis site, including simulated temperatures, measures of bias, and associated root mean-square error for observed temperatures at 0.5 foot below the streambed, 1.0 feet below the streambed, 1.5 feet below the streambed, and 3.0 feet below the streambed..........46

35. Photograph showing in-stream wells at the San Joaquin River at the Vernalis site during low-flow conditions

36. Graphs showing distribution of river gain and river loss in cubic feet per second per mile during the irrigation and non-irrigation seasons for the Newman, Crows Landing, and Vernalis sites.

37. Graphs showing stream stage and modeled vertical streambed flux using heat as a tracer at Newman, Crows Landing, and Vernalis sites.

38. Graphs showing measured values Synoptic I, August-September 2007, of hydraulic gradients and specific conductivity at 1 foot below the streambed, and hydraulic gradients and specific conductivity at 3 feet below the streambed 


\section{Figures-Continued}

39. Graphs showing measured values from Synoptic II, August 2008, of hydraulic gradients and specific conductivity at 1 foot below the streambed, and hydraulic gradients and specific conductivity at 6 feet below the streambed.

40. Graphs showing hydraulic gradients and specific conductivity measured during Synoptic III, September 2008, at the Newman, Crows Landing, Patterson, West Stanislaus Road, Orchard Road, and Vernalis sites.

41. Graphs showing specific conductivity values measured in area 1 during Synoptic IV, June 2009, at 1-foot depth and 3-feet depth

42. Graphs showing specific conductivity values measured in area 2 during Synoptic IV, June 2009, at 1-foot depth and 3-feet depth

43. Graphs showing specific conductivity values measured in area 3 during Synoptic IV, June 2009, at 1-foot depth and 3-feet depth

44. Graphs showing spatial trends in water-quality samples collected from bank wells and in-stream wells during 2006-08 for specific conductivity, nitrate, and ammonium

45. Graphs showing temporal variability in specific conductivity measured over the study period for the bank well sites Newman, Crows Landing, Patterson and instream wells sites Orchard Road, West Stanislaus Road, and Vernalis

46. Graphs showing temporal variability in nitrate concentrations over the monitoring period for the bank well sites at Newman, Crows Landing, Patterson and in-stream wells sites, Orchard Road, West Stanislaus Road, and Vernalis.

47. Graphs showing temporal variability in ammonium concentrations over the monitoring period for the bank well sites at Newman, Crows Landing, Patterson and in-stream wells, Orchard Road, West Stanislaus Road, and Vernalis.

48. Graphs showing temporal variability in dissolved organic carbon concentrations over the monitoring period for the bank well sites at Newman, Crows Landing, Patterson and in-stream wells sites, Orchard Road, West Stanislaus Road, and Vernalis

49. Graphs showing comparison of the 2006-08 and 1988 data for bank wells sampled during both study periods for nitrate concentrations and specific conductivity

50. Graphs showing measured specific conductivity in groundwater below the streambed of the San Joaquin River, at each transect for Synoptics I-IV, in shallow depths and deep depths

51. Graphs showing comparison of specific conductivity measured at shallow depth versus deep depths in groundwater below the streambed of the San Joaquin River during Synoptic I, Synoptic II, Synoptic III, and Synoptic IV

52. Graphs showing measured detections of nitrate concentrations in groundwater below the streambed of the San Joaquin River at each transect for Synoptics I-IV for shallow depth and deep depth

53. Graphs showing comparison of dissolved oxygen, nitrate, and ammonium concentrations measured during Synoptic I in the San Joaquin River, 1 foot below the streambed, and 3 feet below the streambed

54. Graphs showing comparison of dissolved oxygen, nitrate, and ammonium concentrations measured during Synoptic II in the San Joaquin River, 1 foot below the streambed, and 6 feet below the streambed..

55. Graphs showing measured detections of ammonium concentrations for each transect for Synoptics I-IV in shallow depth and deep depth 


\section{Figures-Continued}

56. Graphs showing measured detections of dissolved organic carbon concentrations

for each transect for Synoptics I-IV in shallow depths and deep depths.

57. Map showing colored dissolved organic matter fluorescence measurements recorded during the longitudinal profile survey over the 59-mile reach of the San Joaquin River during Synoptic I, August 2007.

58. Map showing specific conductivity measurements recorded during the longitudinal profile survey over the 59-mile reach of the San Joaquin River during Synoptic I, August 2007.

59. Map showing estimated chlorophyll- $\alpha$ concentration measurements recorded during the longitudinal profile survey over the 59-mile reach of the San Joaquin River during Synoptic I, August 2007.

60. Map showing temperature measurements recorded during the longitudinal profile survey over the 59-mile reach of the San Joaquin River during Synoptic I, August 2007

61. Map showing dissolved oxygen measurements recorded during the longitudinal profile survey over the 59-mile reach of the San Joaquin River during Synoptic I, August 2007

62. Map showing nitrate concentration measurements recorded during the longitudinal profile survey over the 59-mile reach of the San Joaquin River during Synoptic II, September 2008

63. Map showing colored dissolved organic matter fluorescence measurements recorded during the longitudinal profile survey over the 59-mile reach of the San Joaquin River during Synoptic II, September 2008.

64. Map showing estimated chlorophyll- $\alpha$ concentration measurements recorded during the longitudinal profile survey over the 59-mile reach of the San Joaquin River during Synoptic II, September 2008.

65. Map showing temperature measurements recorded during the longitudinal profile survey over the 59-mile reach of the San Joaquin River during Synoptic II, September 2008.

66. Map showing dissolved oxygen measurements recorded during the longitudinal profile survey over the 59-mile reach of the San Joaquin River during Synoptic II, September 2008.

67. Map showing specific conductivity measurements recorded during the longitudinal profile survey over the 59-mile reach of the San Joaquin River during Synoptic II, September 2008.

68. Map showing colored dissolved organic matter fluorescence measurements recorded during the longitudinal profile survey over a 45-mile reach of the San Joaquin River during October 2008.

69. Map showing specific conductivity measurements recorded during the longitudinal profile survey over a 45-mile reach of the San Joaquin River during October 2008.

70. Map showing temperature measurements recorded during the longitudinal profile survey over a 45-mile reach of the San Joaquin River during October 2008.

71. Map showing estimated chlorophyll- $\alpha$ concentration measurements recorded during the longitudinal profile survey over a 45 -mile reach of the San Joaquin River during October 2008 


\section{Figures-Continued}

72. Map showing dissolved oxygen measurements recorded during the longitudinal profile survey over a 45-mile reach of the San Joaquin River during October 2008 .......91

73. Graphs showing distribution of nitrate and nitrite concentrations measured during Synoptics I-IV at the shallow and deep depths..................................................93

74. Graphs showing distribution of ammonium and dissolved organic carbon concentrations measured during Synoptics I-IV at the shallow and deep depths ........94

75. Graph showing instantaneous loads of nitrate, nitrite, ammonium, and dissolved organic carbon in the San Joaquin River at Vernalis that coincide with the streambed synoptic surveys (August 2007-June 2009)

\section{Tables}

1. San Joaquin Valley water-year hydrologic classification values and corresponding index type

2. San Joaquin Valley water-year hydrologic classification index for the previous study and (2006-08) study periods.

3. Comparison of the ranges of mean daily flows as a percentage of the long-term average of mean daily flow (1975-2009) at the most downstream site, San Joaquin River (SJR) at Vernalis, and the most upstream site, SJR at Newman, for each of the sampling approaches and sampling period.....

4. List of well-cluster site names, well type, screened depth, well identifiers, and State well numbers

5. Summary of the total number of environmental samples, laboratory replicates, and laboratory spikes analyzed for nitrate, ammonium, and dissolved organic carbon.

6. Simulated groundwater discharge rates to the San Joaquin River for the past and 2007-08 modeled periods.

7. Summary of sensitivity analysis performed on the in-stream wells modeled with heat as a tracer

8. Summary of streambed sediment textures, streambed hydraulic conductivity, and average vertical streambed flux values for the non-irrigation and irrigation seasons

9. Comparison of hydraulic gradient and specific conductivity values measured during Synoptic I and Synoptic II.

10. Comparison of hydraulic gradient and specific conductivity values measured during Synoptic I and during Synoptic II in transects near the wastewatertreatment plant ponds. 


\section{Conversion Factors}

Inch/Pound to SI

\begin{tabular}{|c|c|c|}
\hline Multiply & By & To obtain \\
\hline \multicolumn{3}{|c|}{ Length } \\
\hline inch (in.) & 2.54 & centimeter $(\mathrm{cm})$ \\
\hline inch (in.) & 25.4 & millimeter (mm) \\
\hline foot (ft) & 0.3048 & meter (m) \\
\hline mile (mi) & 1.609 & kilometer (km) \\
\hline \multicolumn{3}{|c|}{ Area } \\
\hline square mile $\left(\mathrm{mi}^{2}\right)$ & 259.0 & hectare (ha) \\
\hline square mile $\left(\mathrm{mi}^{2}\right)$ & 2.590 & square kilometer $\left(\mathrm{km}^{2}\right)$ \\
\hline \multicolumn{3}{|c|}{ Volume } \\
\hline cubic foot $\left(\mathrm{ft}^{3}\right)$ & 28.32 & liter (L) \\
\hline cubic foot $\left(\mathrm{ft}^{3}\right)$ & 0.02832 & cubic meter $\left(\mathrm{m}^{3}\right)$ \\
\hline acre-foot (acre-ft) & 1,233 & cubic meter $\left(\mathrm{m}^{3}\right)$ \\
\hline acre-foot (acre-ft) & 0.001233 & cubic hectometer $\left(\mathrm{hm}^{3}\right)$ \\
\hline \multicolumn{3}{|c|}{ Flow rate } \\
\hline cubic foot per second $\left(\mathrm{ft}^{3} / \mathrm{s}\right)$ & 0.02832 & cubic meter per second $\left(\mathrm{m}^{3} / \mathrm{s}\right)$ \\
\hline inch per year (in/yr) & 25.4 & millimeter per year (mm/yr) \\
\hline \multicolumn{3}{|c|}{ Hydraulic conductivity } \\
\hline foot per day (ft/d) & 0.3048 & meter per day $(\mathrm{m} / \mathrm{d})$ \\
\hline \multicolumn{3}{|c|}{ Hydraulic gradient } \\
\hline foot per mile ( $\mathrm{ft} / \mathrm{mi})$ & 0.1894 & meter per kilometer $(\mathrm{m} / \mathrm{km})$ \\
\hline
\end{tabular}

Temperature in degrees Celsius $\left({ }^{\circ} \mathrm{C}\right)$ may be converted to degrees Fahrenheit $\left({ }^{\circ} \mathrm{F}\right)$ as follows: ${ }^{\circ} \mathrm{F}=\left(1.8 \times^{\circ} \mathrm{C}\right)+32$

Temperature in degrees Fahrenheit $\left({ }^{\circ} \mathrm{F}\right)$ may be converted to degrees Celsius $\left({ }^{\circ} \mathrm{C}\right)$ as follows: ${ }^{\circ} \mathrm{C}=\left({ }^{\circ} \mathrm{F}-32\right) / 1.8$

*Transmissivity: The standard unit for transmissivity is cubic foot per day per square foot times foot of aquifer thickness [(ft $\left.\left.\mathrm{ft}^{3} \mathrm{~d}\right) / \mathrm{ft}^{2}\right] \mathrm{ft}$. In this report, the mathematically reduced form, foot squared per day $\left(\mathrm{ft}^{2} / \mathrm{d}\right)$, is used for convenience.

Specific conductivity is given in millisiemens per centimeter at 25 degrees Celsius $(\mathrm{mS} / \mathrm{cm}$ at $\left.25^{\circ} \mathrm{C}\right)$.

Concentrations of chemical constituents in water are given either in milligrams per liter (mg/L) or micrograms per liter $(\mu \mathrm{g} / \mathrm{L})$.

Vertical coordinate information is referenced to North American Vertical Datum of 1988 (NAVD88).

Horizontal coordinate information is referenced to North American Datum of 1983 (NAD83).

Elevation, as used in this report, refers to distance above the vertical datum.

Sea level in this report refers to mean sea level based on NAVD88. 


\section{Abbreviations}

\begin{tabular}{|c|c|}
\hline ASTM & American Standard Testing and Materials \\
\hline CALFED & California Bay Delta Authority \\
\hline CDOM & colored dissolved organic matter \\
\hline CE & Crows Landing East (bank well) \\
\hline CRD & Crows Landing river deep (in-stream well) \\
\hline CRS & Crows Landing river shallow (in-stream well) \\
\hline CV & coefficient of variance \\
\hline CW & Crows Landing West (bank well) \\
\hline DIN & dissolved inorganic nitrogen \\
\hline $\mathrm{DOC}$ & dissolved organic carbon \\
\hline DOM & dissolved organic matter \\
\hline DWR & Department of Water Resources \\
\hline EEMS & excitation-emission-matrix Spectroscopy \\
\hline EWI & equal width increment \\
\hline FDOM & fluorescent dissolved organic matter \\
\hline HDPE & high-density polyethylene \\
\hline K & hydraulic conductivity \\
\hline LAWR & Land, Air, and Water Resources (University of California at Davis) \\
\hline MCL & maximum contaminant level (U.S. Environmental Protection Agency) \\
\hline MDL & method detection limit \\
\hline MODFLOW & Modular-finite Difference Groundwater Flow Model \\
\hline NAWQA & National Water Quality Assessment (USGS) \\
\hline NE & Newman East (bank well) \\
\hline NRD & Newman river deep (in-stream well) \\
\hline NRS & Newman river shallow (in-stream well) \\
\hline NW & Newman West (bank well) \\
\hline NWIS & National Water Information System (USGS) \\
\hline ORD & Orchard Road river deep (in-stream well) \\
\hline ORS & Orchard Road river shallow (in-stream well) \\
\hline PE & Patterson East (bank well) \\
\hline PID & Patterson Irrigation District \\
\hline PRD & Patterson river deep (in-stream well) \\
\hline PRS & Patterson river shallow (in-stream well) \\
\hline PW & Patterson West (bank well) \\
\hline
\end{tabular}




\section{Abbreviations-Continued}

$\begin{array}{ll}\text { QC } & \text { quality control } \\ \text { RMSE } & \text { root mean square error } \\ \text { RPD } & \text { relative percentage difference } \\ \text { SC } & \text { specific conductivity } \\ \text { SJR } & \text { San Joaquin River } \\ \text { TAF } & \text { thousand acre-feet } \\ \text { TOC } & \text { total organic carbon } \\ \text { UC Davis } & \text { University of California at Davis } \\ \text { USEPA } & \text { United States Environmental Protection Agency } \\ \text { USGS } & \text { United States Geological Survey } \\ \text { UOP } & \text { University of the Pacific, Stockton, California } \\ \text { UVA } & \text { ultra-violet absorbance } \\ \text { VRD } & \text { Vernalis river deep (in-stream well } \\ \text { VRS } & \text { Vernalis river shallow (in-stream well) } \\ \text { VS2DH } & \text { variably saturated two-dimensional heat model } \\ \text { WRD } & \text { West Stanislaus Road river deep (in-stream well) } \\ \text { WRS } & \text { West Stanislaus Road river shallow (in-stream well) } \\ \text { WWTP } & \text { wastewater-treatment plant } \\ \text { YSI } & \text { Yellow Springs Instruments }\end{array}$

\section{Acknowledgments}

This study was done in cooperation with University of California at Davis. Funding for this project was provided by a Proposition 50 grant from the CALFED Drinking Water-Quality Program and from the University of California at Davis.

We thank Xien Wang for analysis of nutrients and dissolved organic carbon. We thank students Travis von Dessonneck, Liz Beaulieu, Brandy Truong, Rhianna Eads, Micaela Soto, Jay Hefferman, Shane Edmunds, Lisa Jacobs, and Rubi Medrano, Spencer Estridge, Ben and Bernadette, Emily Volkmar, and Calla Schmidt from California State University Sacramento and University of California at Davis for their assistance with field work during the streambed synoptic surveys. We would also like to thank Eric Hopson from the U.S. Fish and Wildlife Service for gate access to several sites.

A special recognition goes to Greg Brewster and Peter Dileanis of the US Geological Survey for countless hours spent in the field installing the in-stream wells and data-logging instrumentation. This project would have not succeeded without their incredible hard work and ingenuity. 


\title{
Groundwater Contributions of Flow, Nitrate, and Dissolved Organic Carbon to the Lower San Joaquin River, California, 2006-08
}

\author{
By Celia Zamora, Randy A. Dahlgren, Charles R. Kratzer, Bryan D. Downing, Ann D. Russell, Peter D. Dileanis, \\ Brian A. Bergamaschi, and Steven P. Phillips
}

\section{Abstract}

The influence of groundwater on surface-water quality in the San Joaquin River, California, was examined for a 59-mile reach from the confluence with Salt Slough to Vernalis. The primary objective of this study was to quantify the rate of groundwater discharged to the lower San Joaquin River and the contribution of nitrate and dissolved organic carbon concentrations to the river. Multiple lines of evidence from four independent approaches were used to characterize groundwater contributions of nitrogen and dissolved organic carbon. Monitoring wells (in-stream and bank wells), streambed synoptic surveys (stream water and shallow groundwater), longitudinal profile surveys by boat (continuous water-quality parameters in the stream), and modeling (MODFLOW and VS2DH) provided a combination of temporal, spatial, quantitative, and qualitative evidence of groundwater contributions to the river and the associated quality.

Monitoring wells in nested clusters in the streambed (in-stream wells) and on both banks (bank wells) along the river were monitored monthly from September 2006 to January 2009. Nitrate concentrations in the bank wells ranged from less than detection - that is, less than 0.01 milligrams per liter (mg/L) as nitrogen $(\mathrm{N})$ — to approximately $13 \mathrm{mg} / \mathrm{L}$ as N. Nitrate was not detected at 17 of 26 monitoring wells during the study period. Dissolved organic carbon concentrations among monitoring wells were highly variable, but they generally ranged from 1 to $4 \mathrm{mg} / \mathrm{L}$. In a previous study, 14 bank wells were sampled once in 1988 following their original installation. With few exceptions, specific conductivity and nitrate concentrations measured in this study were virtually identical to those measured 20 years ago. Streambed synoptic measurements were made by using a temporarily installed drive-point piezometer at 113 distinct transects across the stream during 4 sampling events. Nitrate concentrations exceeded the detection limit of $0.01 \mathrm{mg} / \mathrm{L}$ as $\mathrm{N}$ in 5 percent of groundwater samples collected from the in-stream wells as part of the synoptic surveys. Only 7 of the 113 cross-sectional transects had nitrate concentrations greater than $1 \mathrm{mg} / \mathrm{L}$ as $\mathrm{N}$. In contrast, surface waters in the San Joaquin River tended to have nitrate concentrations in the 1-3 $\mathrm{mg} / \mathrm{L}$ as $\mathrm{N}$ range. A zone of lower oxygen (less than $2 \mathrm{mg} / \mathrm{L}$ ) in the streambed could limit nitrate contributions from regional groundwater flow because nitrate can be converted to nitrogen gas within this zone. Appreciable concentrations of ammonium (average concentration was $1.92 \mathrm{mg} / \mathrm{L}$ as N, and 95th percentile was $10.34 \mathrm{mg} / \mathrm{L}$ as $\mathrm{N}$ ) in the shallow groundwater, believed to originate from anoxic mineralization of streambed sediments, could contribute nitrogen to the overlying stream as nitrate following in-stream nitrification, however. Dissolved organic carbon concentrations were highly variable in the shallow groundwater below the river ( 1 to $6 \mathrm{ft}$ below streambed) and generally ranged between 1 and $5 \mathrm{mg} / \mathrm{L}$, but had maximum concentrations in the 15-25 mg/L range.

The longitudinal profile surveys were not particularly useful in identifying groundwater discharge areas. However, the longitudinal approach described in this report was useful as a baseline survey of measured water-quality parameters and for identifying tributary inflows that affect surfacewater concentrations of nitrate. Results of the calibrated MODFLOW model indicated that the simulated groundwater discharge rate was approximately 1.0 cubic foot per second per mile (cfs/mi), and the predominant horizontal groundwater flow direction between the deep bank wells was westward beneath the river. The modeled (VS2DH) flux values (river gain versus river loss) were calculated for the irrigation and non-irrigation season, and these fluxes were an order of magnitude less than those from MODFLOW. During the irrigation season, the average river gain was $0.11 \mathrm{cfs} / \mathrm{mi}$, and the average river loss was $-0.05 \mathrm{cfs} / \mathrm{mi}$. During the nonirrigation season, the average river gain was $0.10 \mathrm{cfs} / \mathrm{mi}$, and the average river loss was $-0.08 \mathrm{cfs} / \mathrm{mi}$. 
Information on groundwater interactions and water quality collected for this study was used to estimate loads of nitrate and dissolved organic carbon from the groundwater to the San Joaquin River. Estimated loads of dissolved inorganic nitrogen and dissolved organic carbon were calculated by using concentrations measured during four streambed synoptic surveys and the estimated groundwater discharge rate to the San Joaquin River from MODFLOW of $1 \mathrm{cfs} / \mathrm{mi}$. The estimated groundwater loads to the San Joaquin River for dissolved inorganic nitrogen and dissolved organic carbon were 300 and 350 kilograms per day, respectively. These loads represent 9 and 7 percent, respectively, of the estimated instantaneous surface-water loads for dissolved inorganic nitrogen and dissolved organic carbon at the most downstream site, Vernalis, measured during the four streambed synoptic surveys.

\section{Introduction}

The primary objective of this study was to quantify the rate of groundwater discharge to the lower San Joaquin River (SJR) and the contribution of nitrate $\left(\mathrm{NO}^{3-}\right)$ and dissolved organic carbon (DOC) concentrations to the river. Excess nitrogen $(\mathrm{N})$ in the lower SJR can stimulate algal growth and can affect use of the river as a drinking-water source and as aquatic habitat. Excess algal growth can increase the cost of water treatment for municipalities downstream and can contribute to low dissolved oxygen (DO) concentrations in the SJR near Stockton, which can be deleterious to Chinook salmon migration and could stress and kill other resident aquatic organisms (Hallock and others, 1970; California Regional Water Quality Control Board, Central Valley Region, 2005). DOC can be a drinking-water issue because of the potential for forming disinfection byproducts during the treatment process (for example, chlorination) because components of the DOC pool can react to form toxic halogenated compounds (Krasner and others, 2006; Richardson and others, 2007).

Results of previous work (Kratzer and others, 2004; Burow and others, 1998) indicated that some of the long-term increase (over 50 years) in nitrate concentrations in the SJR could be due to groundwater sources. The range of ${ }^{15} \mathrm{~N}$ and ${ }^{18} \mathrm{O}$ values of nitrate in river samples collected in 2000 and 2001 indicated that animal waste or sewage was a significant source of nitrogen in the river at that time (Kratzer and others, 2004). Nitrate can be introduced into an aquifer system from a variety of agricultural and urban sources, including fertilizer use for agriculture and landscape maintenance, animal manure, and septic systems (Landon and others, 2010). This study builds on a previous U.S. Geological Survey (USGS) study of groundwater contribution to the lower SJR done in 1986-89 (Phillips and others, 1991). The previous study included bank and in-stream nested monitoring wells at three
sites-Newman, Crows Landing, and Patterson, California. By using a layered model, the simulated groundwater discharge rates at these sites were 1.8, 1.1, and 3.2 cubic feet per second per mile (cfs/mi), respectively (Phillips and others, 1991). A calibrated input-output model of the lower 60 miles (mi) of the SJR by Kratzer and others (1987) estimated groundwater discharge rates at these sites at 1.7, 1.4, and 1.4 $\mathrm{cfs} / \mathrm{mi}$, respectively. In addition, several large-scale regional operations models have developed estimates of groundwater contributions to the lower SJR (Water Resources and Information Management Engineering, Inc., 2003; Draper and others, 2004).

\section{Purpose and Scope}

The purpose of this report is to address the contribution of nitrate and DOC from the groundwater system to the lower SJR during below-normal flow conditions (fig. 1). Information on groundwater discharge and quality was used to estimate loads of nitrate and DOC from the groundwater to the SJR. The objective of this study was to quantify the amount of groundwater contribution (in cubic feet per second per mile) to the lower SJR and its nitrate and DOC concentrations by using four approaches. Four approaches-monitoring wells, streambed synoptic surveys, longitudinal profile surveys by boat, and modeling — provide a combination of temporal, spatial, quantitative, and qualitative evidence of groundwater contributions and the associated water quality. Groundwater interactions with the SJR were characterized by evaluating surface flows, groundwater levels, temperature data, and the modeling results. Water-quality results for nutrients, DOC, and specific conductivity (SC) are presented and interpreted to meet the study objectives. In addition to these data, phosphate, boron, bromide, major cations and anions, optical parameters of dissolved organic matter, $\mathrm{pH}$, dissolved oxygen, and temperature data were collected, but not interpreted, in this report. These additional data are presented in appendixes 4-7.

\section{Description of the Study Area}

From its headwaters in the Sierra Nevada to the Sacramento-San Joaquin Delta, the SJR is the second longest river in California and has a drainage area of 13,536 square miles $\left(\mathrm{mi}^{2}\right)$. The diversion of water from the upper SJR for irrigation through the Madera and Friant-Kern Canals, however, has caused sections of the SJR to go dry in most years since the completion of Friant Dam and the canals in 1951 (http://www.usbr.gov/projects/Project.jsp?proj_ Name=Friant\%20Division\%20Project, accessed May 1, 2013; http://cdec.water.ca.gov/cgi-progs/stamap?MIL, accessed May 1, 2013) . The drainage area for this perennial, lower San Joaquin Basin (originating with Bear Creek) is 7,395 mi² (fig. 1). 


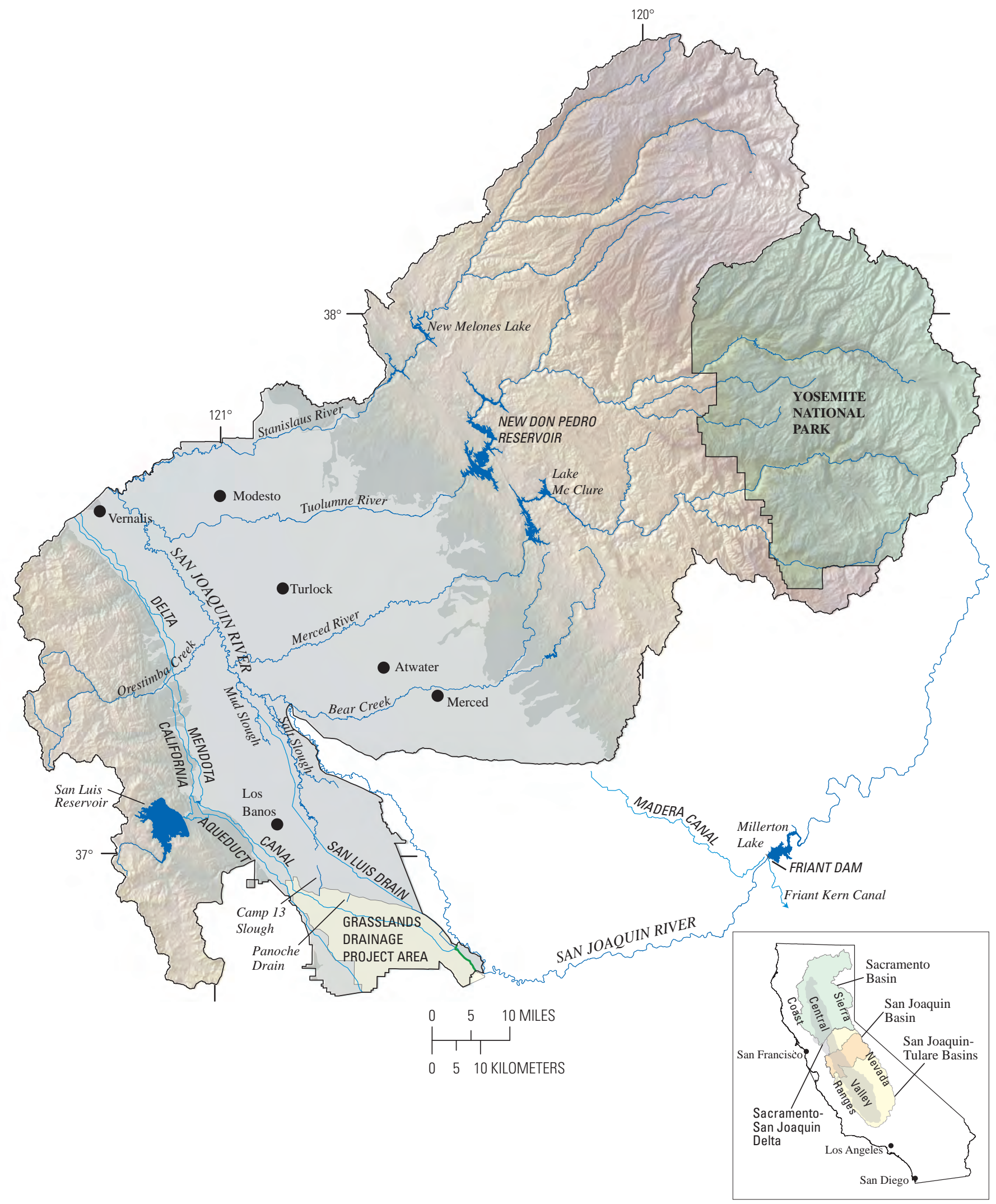

Figure 1. Perennial San Joaquin Basin and major waterways. 


\section{Physiography and Geology}

The lower San Joaquin Basin includes parts of three physiographic provinces - the Coast Ranges, California Trough, and Sierra Nevada (fig. 2). The boundary of the lower San Joaquin basin is defined by the drainage divides of the Coast Ranges on the west, the Sierra Nevada on the east, and the Sacramento-San Joaquin Delta to the north. The crests of the Coast Ranges in this perennial lower San Joaquin basin are about 4,000 feet (ft) above the vertical datum (North American Vertical Datum of 1988), and the Sierra Nevada are about $13,000 \mathrm{ft}$. The elevation of the San Joaquin Valley ranges from about $200 \mathrm{ft}$ in the south to near sea level in the north at the Sacramento-San Joaquin Delta.

The compositions of the sediments in the San Joaquin Valley reflect their source areas and manner of deposition. Alluvial deposits on the eastern side of the valley were derived primarily from the weathering of granitic intrusive rocks of the Sierra Nevada, with lesser contributions from the sedimentary rocks of the foothills. These Sierran alluvial deposits are highly permeable, medium- to coarse-grained sands that form broad alluvial fans where the streams enter the valley. The Coast Range alluvium on the western side of the valley tends to be of finer texture relative to those of the eastern side because they are derived from the Coast Range sedimentary rocks. In the valley trough, stream-channel deposits are flanked by basin deposits of varying extent. These basin deposits are interbedded lacustrine, marsh, overbank, and stream-channel sediments deposited by the numerous sloughs and meanders of the major rivers. These deposits generally have high clay content and low permeability (Davis and Hall, 1959).

\section{Surface Water}

The lower San Joaquin Basin has an overall longterm average annual precipitation (1980-97) of 28 inches (13 inches in the valley portion only, fig. 3), falling mostly from November through March (National Center for Atmospheric Research, 2003). The eastern slopes of the Coast Ranges and the San Joaquin Valley are in the rain shadow of the Coast Ranges. East of the San Joaquin Valley, warm, moist air masses from the Pacific Ocean are forced aloft by the Sierra Nevada. The air masses cool, and the moisture condenses, resulting in heavy precipitation on the western slopes of the Sierra Nevada. This precipitation, falling both as rainfall and snow, is the major source of water entering the lower SJR Basin. Precipitation in the valley ranges from 7 inches per year (in/yr) in the south to $15 \mathrm{in} / \mathrm{yr}$ in the north. Precipitation in the Coast Ranges ranges from less than $10 \mathrm{in} / \mathrm{yr}$ to more than $16 \mathrm{in} / \mathrm{yr}$. Precipitation in the Sierra Nevada ranges from about $20 \mathrm{in} / \mathrm{yr}$ in the lower foothills to more than $60 \mathrm{in} / \mathrm{yr}$ at some higher elevation sites.

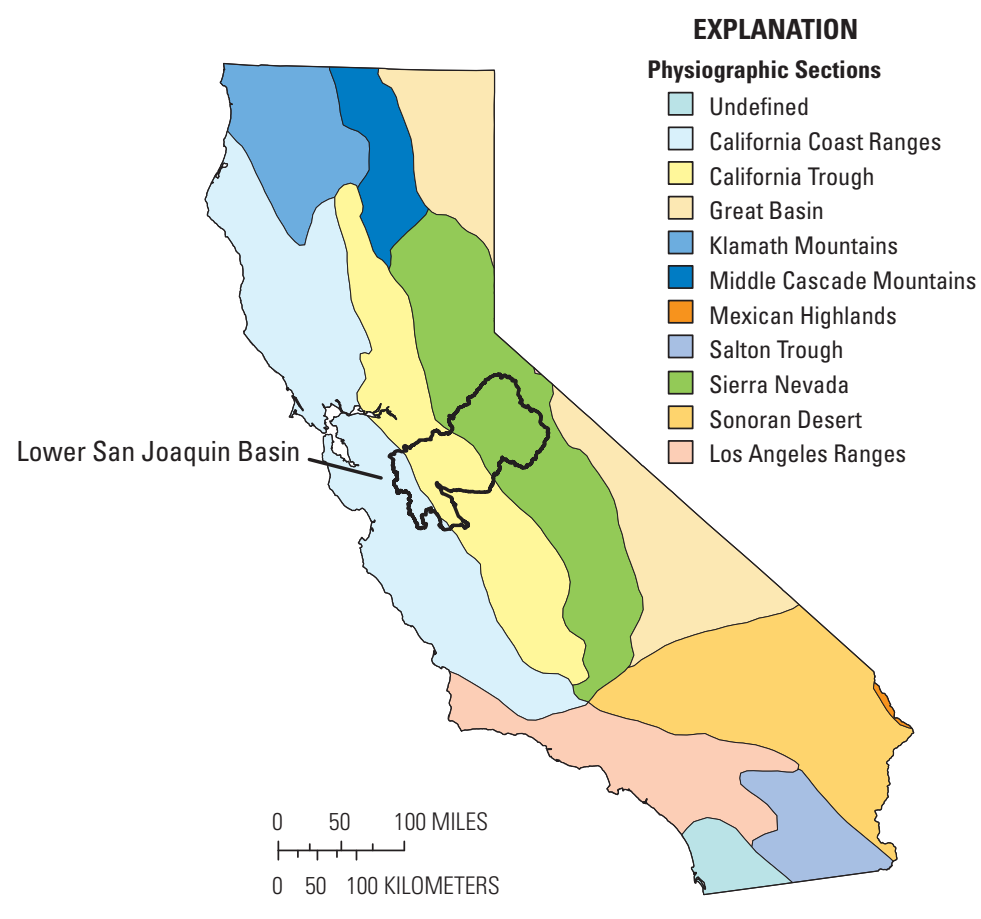

(Source: http://water.usgs.gov/GIS/metadata/usgswrd/XML/physio.xml)

Figure 2. Physiographic provinces of California within the lower San Joaquin Basin. 
All the major rivers of the lower San Joaquin BasinMerced, Tuolumne, and Stanislaus_-have impoundments just above the margin of the San Joaquin Valley (fig. 1). Lake McClure, on the Merced River, has a capacity of 1,026 thousand acre-ft (TAF). New Don Pedro Reservoir, on the Tuolumne River, has a capacity of 2,030 TAF. New Melones Reservoir, on the Stanislaus River, has a capacity of
2,400 TAF. These reservoirs are managed for irrigation water supply, hydroelectric power production, recreation, and some municipal water supply. For the entire San Joaquin Basin in 2000, agriculture accounted for about 57 percent of applied water use, environmental uses accounted for 38 percent, and urban use for 5 percent (California Department of Water Resources, 2005).

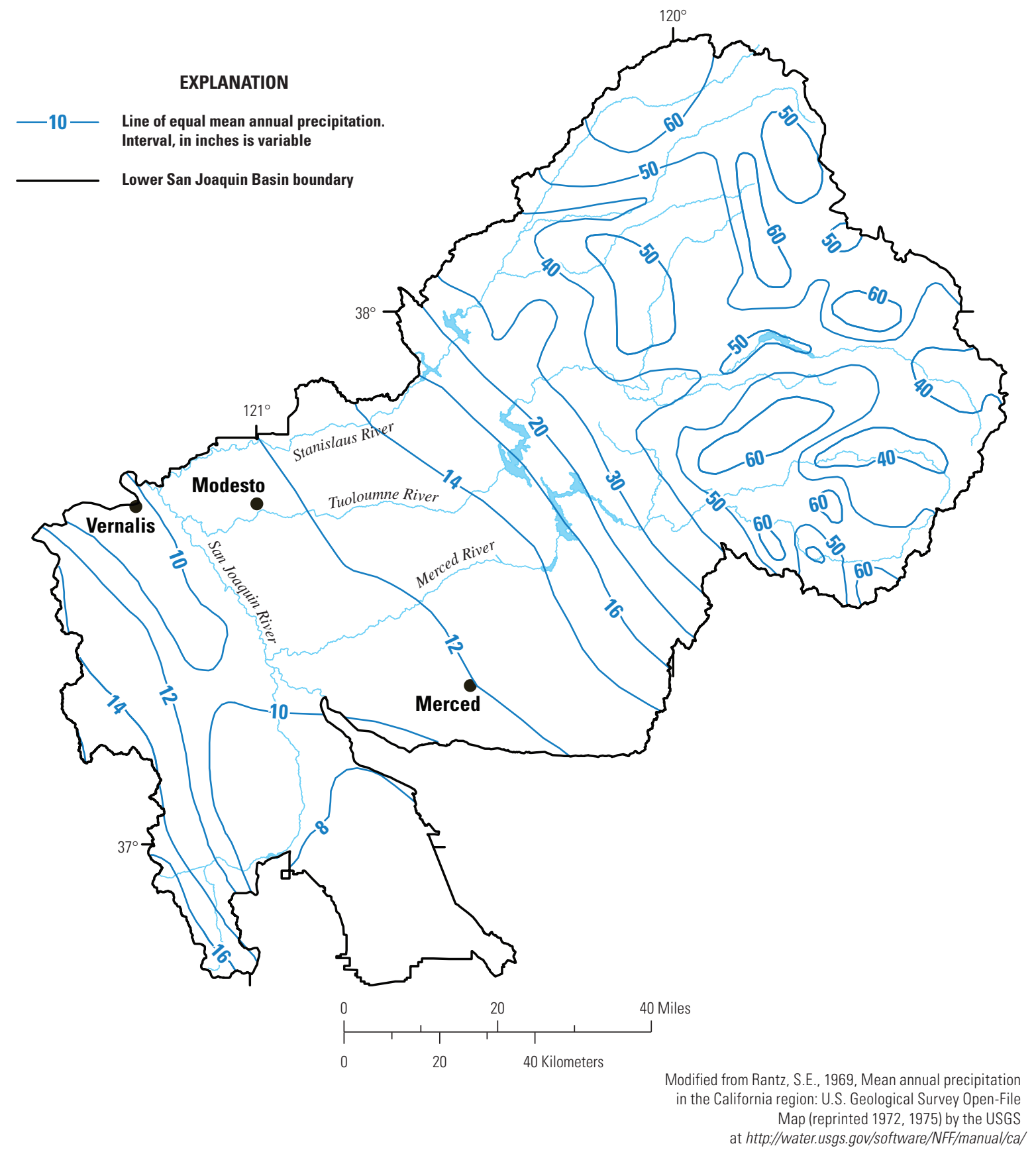

Figure 3. Distribution of mean annual precipitation (1980-97) for the lower San Joaquin Basin. 
Water availability in the San Joaquin Basin can be characterized by a water-year index (table 1 ) as wet, above normal, below normal, dry, and critical for each water year (October 1-September 30; http://cdec.water.ca.gov/cgi-progs/ iodir/WSIHIST, accessed December 2, 2010). The 60-20-20 water-year index is used for the basin (California Department of Water Resources, 2004a). This index represents available water as percentages for three variables: the forecasted unimpaired runoff from April through July (60 percent), the forecasted, unimpaired runoff from October through March (20 percent), and the reservoir carryover storage from the previous water year constrained by a maximum allowable value (20 percent). Unimpaired runoff represents the natural water production of a river basin, unaltered by upstream

Table 1. San Joaquin Valley water-year hydrologic classification values and corresponding index type.

$[>$, greater than; $<$, less than; $\geq$, greater than or equal to; $\leq$, less than or equal to]

\begin{tabular}{ll}
\hline \multicolumn{1}{c}{ Water-year $^{\mathbf{1}}$ index } & Water-year type $^{2}$ \\
$\geq 3.8$ & Wet \\
$>3.1$ and $<3.8$ & Above normal \\
$>2.5$ and $\leq 3.1$ & Below normal \\
$\geq 2.1$ and $\leq 2.5$ & Dry \\
$\leq 2.1$ & Critical \\
\hline
\end{tabular}

${ }^{1}$ Water year begins on October 1st and ends on September 30th.

${ }^{2}$ Refers to the water availability in the San Joaquin Basin characterized by the water-year index. See figure 4. diversions, storage, and export of water to or import of water from other basins. For the San Joaquin Basin, the unimpaired runoff is the sum of the runoff in the Stanislaus River inflow to New Melones Reservoir, Tuolumne River inflow to New Don Pedro Reservoir, Merced River inflow to Lake McClure, and SJR inflow to Millerton Lake. The classifications for 1901-2009 water years are shown in figure 4 (California Department of Water Resources, 2004b; http://cdec.water. ca.gov/cgi-progs/iodir/WSIHIST, accessed June 9, 2010). This record shows high variability with periods of wetter conditions alternating with periods of drier conditions. The long-term average unimpaired streamflow entering the San Joaquin Basin is about 8,232 cubic feet per second $\left(\mathrm{ft}^{3} / \mathrm{s}\right.$; http://cdec.water.ca.gov/cgi-progs/iodir/WSIHIST, accessed June 9, 2010) compared to about 4,500 ft $\mathrm{ft}^{3} / \mathrm{s}$ (National Water Information System; Kratzer and others, 2010) leaving the San Joaquin Basin to the Sacramento-San Joaquin Delta, with the difference being primarily consumptive use by agriculture in the San Joaquin Valley.

In the San Joaquin Valley, surface water is reused many times because there are almost 100 diversion points for agricultural use and over 100 discharge points of agricultural return flow, which are spatially interspersed with one another (Kratzer and Shelton, 1998; figs. 5, 6). Thus, much of the water that is discharged from a site upstream never makes it to the Sacramento-San Joaquin Delta by way of the SJR. The two largest agricultural diversions-Patterson Irrigation District (PID) and West Stanislaus Irrigation District—can each divert more than half the river flow during low-flow summer periods (fig. 5; Quinn and Tulloch, 2002; Kratzer and others, 2010).

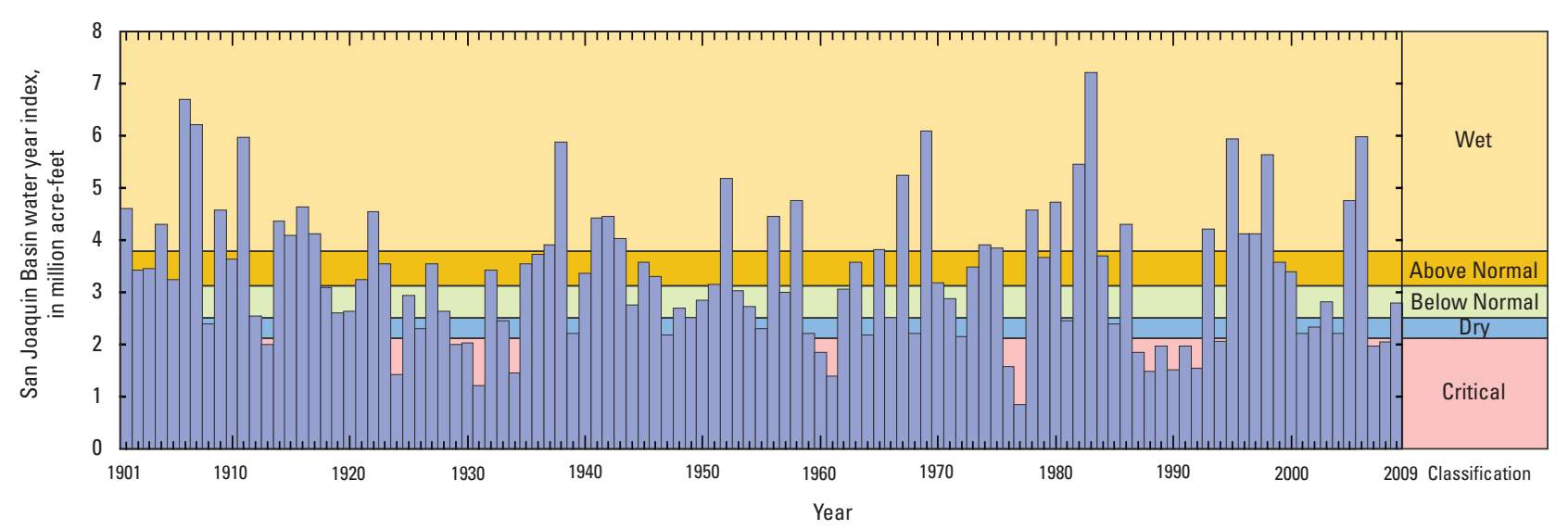

Source: California Department of Water Resources, 2004b, WSIHIST Chronological reconstructed Sacramento and San Joaquin Valley water year hydrologic classification indices., 6 p., accessed May 3, 2013, at URL http://cdec.water.ca.gov/cgi-progs/iodir/WSIHIST

Figure 4. Water-year index and hydrologic classification for 1901-2009 for the San Joaquin Basin. 


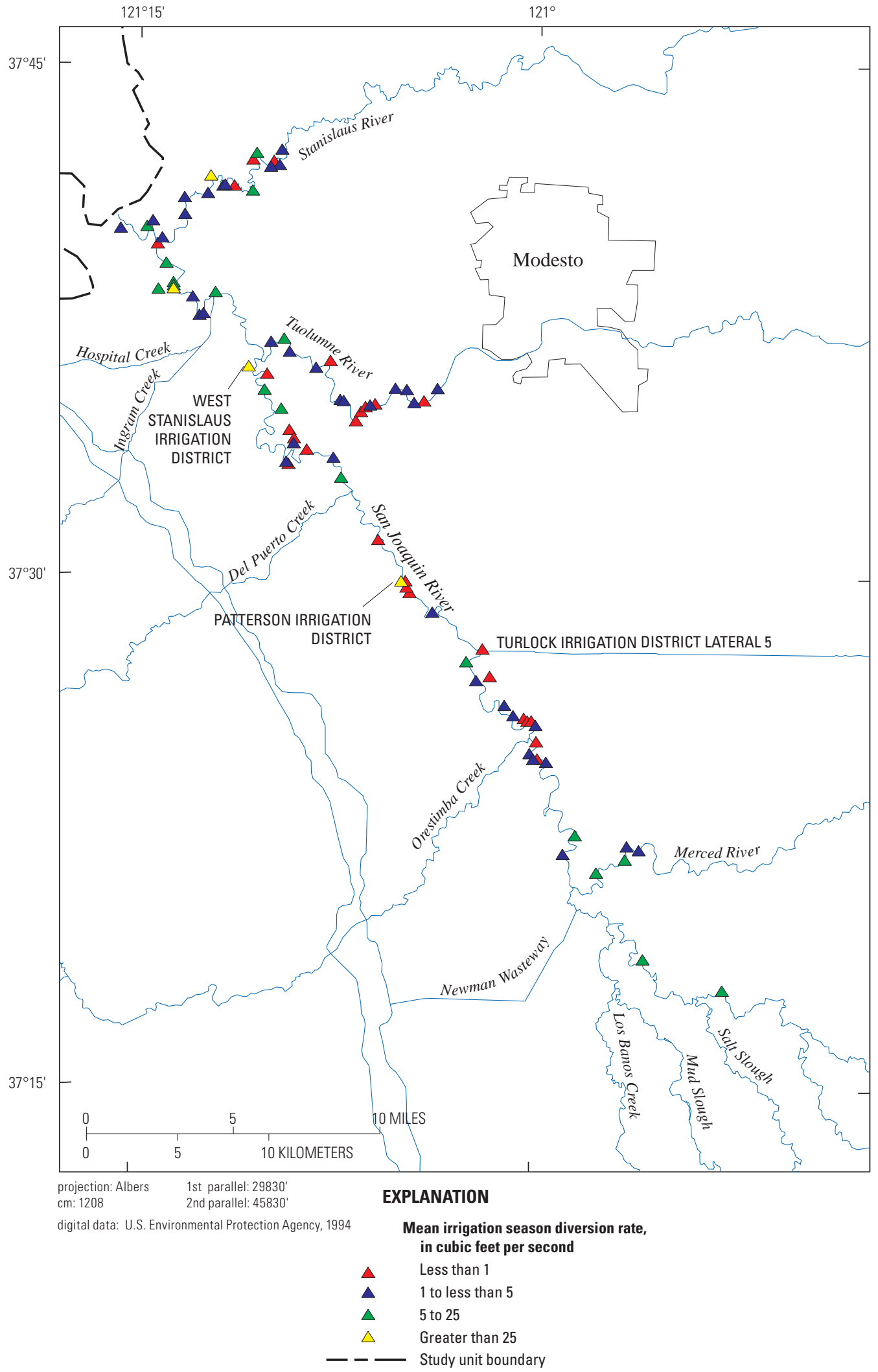

Figure 5. Diversion points for agricultural use in the San Joaquin Valley. 


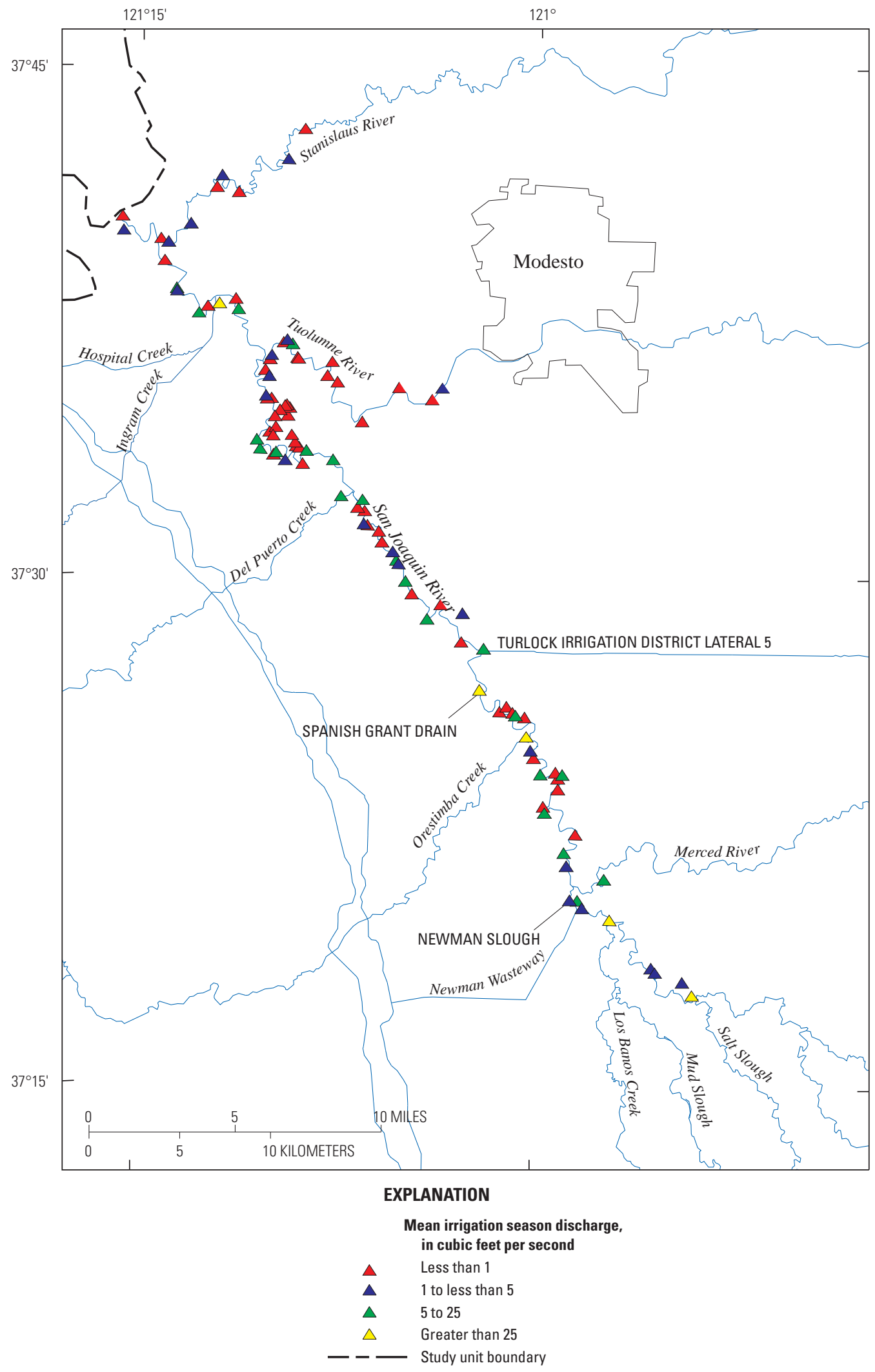

Figure 6. Discharge points of agricultural return flow in the San Joaquin Valley. 


\section{Groundwater}

The sediments of the San Joaquin Valley compose an aquifer system consisting of confining units and unconfined, semi-confined, and confined aquifers. This aquifer system generally consists of alluvial deposits shed from the surrounding Sierra Nevada and Coast Ranges (Faunt, 2009). The chief water-bearing unit in the San Joaquin Valley is located within the upper $1,000 \mathrm{ft}$ of deposits (Page, 1986). Fresh groundwater (dissolved solids less than 2,000 milligrams per liter) is at depths of more than $3,000 \mathrm{ft}$ in the alluvial deposits that fill structural troughs along the western side of the Sacramento Valley and in the southern part of the San Joaquin Valley (Faunt, 2009). Below the freshwater zone is saline water, which is primarily connate water contained in the thick, marine sedimentary rocks (Planert and Williams, 1995).

During the Pleistocene epoch, an area of as much as $6,600 \mathrm{mi}^{2}$ of the San Joaquin Valley was inundated by lakes that accumulated up to $150 \mathrm{ft}$ of diatomaceous clay, often referred to as the E-clay or the Corcoran Clay (Corcoran Clay Member of Turlock Lake Formation; Page and Bertoldi, 1983; Farrar and Bertoldi, 1988). This clay has low permeability, is areally extensive, and consists of a lacustrine deposit as much as $200 \mathrm{ft}$ thick (Davis and others, 1959, Page, 1986). This clay (the Corcoran Clay) divides the groundwater-flow system of the western San Joaquin Valley into an upper semi-confined zone and a lower confined zone of groundwater flow (Belitz and Heimes, 1990; Burrow and others, 2004). The depth of the clay varies throughout the San Joaquin Valley and ranges from $850 \mathrm{ft}$ below land surface in the southern San Joaquin Valley in the Tulare Lake Bed of Kings County to $100 \mathrm{ft}$ below land surface near the city of Turlock, California, in northern San Joaquin Valley (Page, 1986). In the study area (along the SJR), the clay lies approximately 200-230 ft below land surface. Flow between the unconfined and confined zones is believed to be negligible in the study area (Phillips and Belitz, 1990). Contour maps of water-table elevation and potentiometric surface below the Corcoran Clay indicate little or no vertical hydraulic gradient across the clay; the results of previous studies indicate that the hydraulic conductivity of this clay is at least 10,000 times lower than that of the Sierran alluvial deposits (Johnson and others, 1968; Phillips and Belitz, 1990).

Agricultural practices greatly influence the groundwater flow system in the study area. Irrigation is the primary source of recharge within the study area, supplementing much smaller amounts of recharge from precipitation and infiltration from streams. Pumping of groundwater from agricultural wells is the primary discharge mechanism, supplementing the natural mechanisms of evapotranspiration and discharge to the SJR (Phillips and others, 1991). The long-term effects of irrigation and withdrawal of water from the wells can be seen in the regional water table and in the water levels recorded in observation wells throughout the San Joaquin Valley.

\section{Land Use}

In the San Joaquin Basin, the Sierra Nevada are predominately forested land, the Coast Ranges and the foothills of the Sierra Nevada are primarily rangeland, and the San Joaquin Valley floor is dominated by agriculture (fig. 7). In 2000, an area of about $1,000 \mathrm{mi}^{2}$ of the lower SJR Basin was irrigated (California Department of Water Resources, 2001). The distribution of crops in the valley generally reflects the distribution of soil texture and chemistry. Orchards and vineyards are primarily on the well-drained alluvial fan soils of the eastern side of the valley. Cotton, a salt-tolerant crop, is the principal crop grown on the basin deposits at the southern end of the basin. Row crops, such as beans, are grown primarily on the alluvial fans of the western side. Land along the eastern side of the SJR is used primarily for corn, alfalfa, pasture, and dairies. In 2000, the total value of agricultural production in the entire San Joaquin Valley was about 8 billion dollars. This represented about 10 percent of the U.S. agricultural production and about 50 percent of California's total agricultural production. The major products (in total value) in the San Joaquin Valley were livestock and livestock products (35 percent), fruits and nuts (33 percent), cotton (13 percent), vegetables ( 6.5 percent), hay and grains (6 percent), and other crops (6.5 percent; Gronberg and others, 1998).

The major population centers of the lower San Joaquin Basin are located in the San Joaquin Valley (fig. 1). The total 2000 population of the lower SJR Basin was about 729,000 (U.S. Census Bureau, 2001b-2001e). Cities with over 50,000 population in the basin include Modesto $(189,000)$, Merced (64,000), and Turlock (56,000; U.S. Census Bureau, 2001a). Population growth in the basin for 1980-2000 was about 64 percent, compared to 43 percent in California and 31 percent in the United States (U.S. Census Bureau, 2001a). 


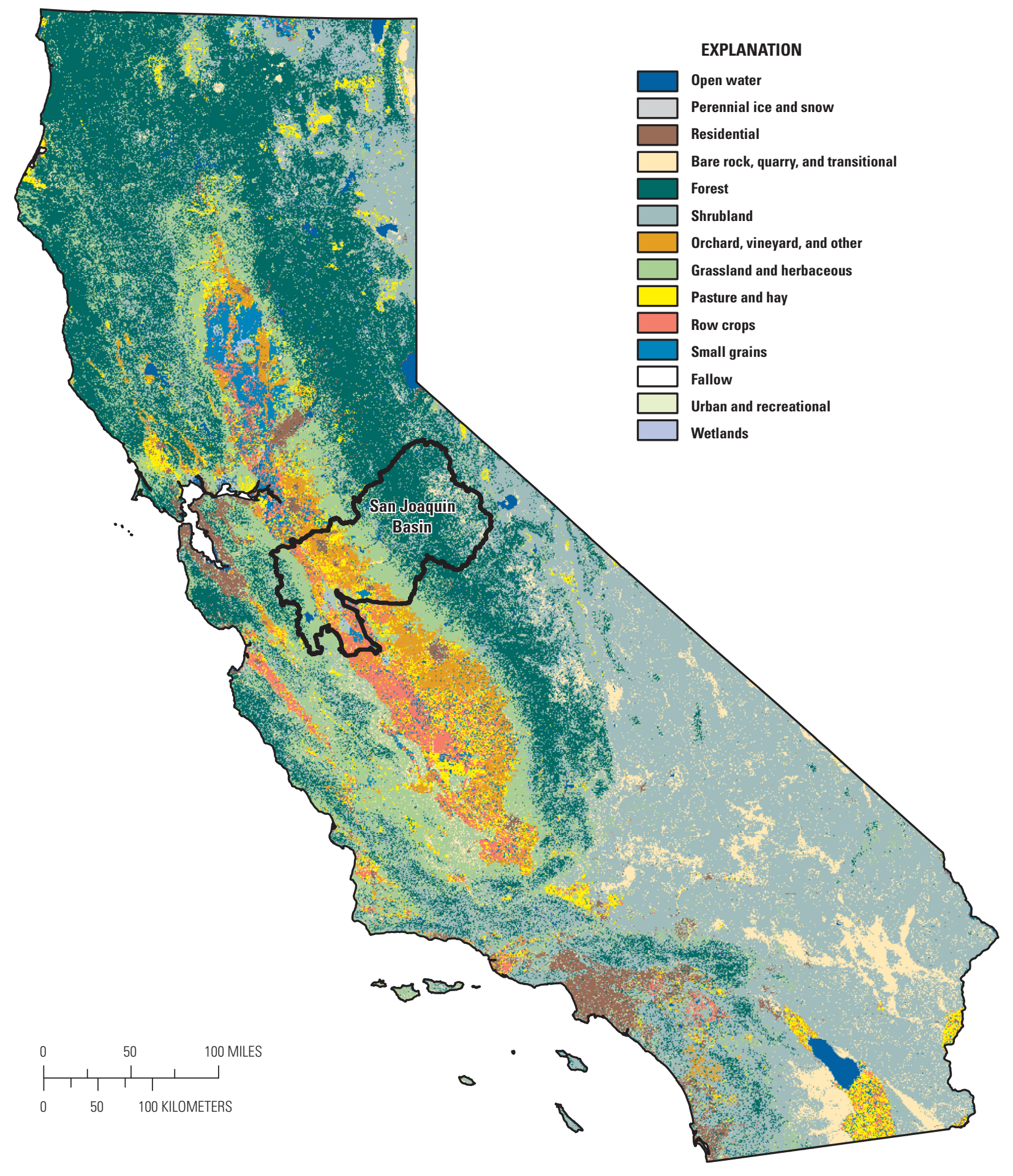

Source: http://water.usgs.gov/nawqa-only/gis/data/n/cdep1km.htm/

Figure 7. Land use in San Joaquin Basin. 


\section{Hydrologic Conditions during the Study Period}

Surface-water and groundwater conditions from 2006 to 2009 were compared to long-term conditions (1975-2009). The water availability in the San Joaquin Basin, based on the water-year index values for water years 2006, 2007, 2008, and 2009 (water year is October 1 to September 30), were wet, critical, critical, and below-normal water-year types, respectively (fig. 4, table 2). The previous study by Phillips and others (1991) took place during an extended dry period (water years 1987-89) corresponding to critically dry water years (fig. 4, table 2); however, the water year (1986) before that study began was wet, with an index value of 4.31 (California Department of Water Resources, http://cdec.water. ca.gov/cgi-progs/iodir/WSIHIST, accessed December 2, 2010).

\section{Surface Water}

The daily mean flows at the most upstream site, SJR at Newman stream gage (11274000), and the most downstream site, SJR near Vernalis stream gage (11303500), for the 2006-09 water years are shown in figure 8, with the long-term average of the mean daily flows collected by the USGS for the 1975-2009 water years. Overall, the flows correspond with the water-year types, with 2006 being well above average and 2007-09 being below average. Table 3 presents the mean daily flow range as a percentage of the long-term mean daily flow average (1975-2009) for SJR at Newman and SJR at Vernalis for each of the sampling approaches used during the study period (National Water Information System, 2009; Kratzer and others, 2010). The monitoring-well sampling (bank and in-stream wells), the streambed synoptic surveys, and longitudinal profile surveys were done during a period of below-normal flows in the SJR.

Table 2. San Joaquin Valley water-year hydrologic classification index for the previous study and (2006-08) study periods.

[See figure 4 and corresponding text for the complete San Joaquin River 1901-2009 water-year index and definition]

\begin{tabular}{llcl}
\hline \multicolumn{1}{c}{ Study } & Study period & Water year $^{\mathbf{1}}$ & Water year index \\
\hline Krazter and others, 1987; Grober and others, 1992 & 1985 & 1985 & Dry \\
Phillips and others, 1991 & $1988-1989$ & 1986 & Wet \\
Phillips and others, 1991 & $1988-1989$ & 1987 & Critical \\
Phillips and others, 1991 & $1988-1989$ & 1988 & Critical \\
Phillips and others, 1991 & $1988-1989$ & 1989 & Critical \\
This study & $2006-2008$ & 2006 & Wet \\
This study & $2006-2008$ & 2007 & Critical \\
This study & $2006-2008$ & 2008 & Critical \\
This study & $2006-2008$ & 2009 & Below normal \\
\hline
\end{tabular}

${ }^{1}$ Water year begins on October 1st and ends on September 30th.

${ }^{2}$ Refers to the water availability in the San Joaquin Basin characterized by the water-year index. See figure 4 .

Source:

California Department of Water Resources, 2004b, WSIHIST Chronological reconstructed Sacramento and San Joaquin Valley water year hydrologic classification indices, 6 p., accessed May 3, 2013, at http:/www.waterboards.ca.gov/waterrights/water_issues/programs/ bay_delta/deltaflow/docs/exhibits/ccwd/spprt_docs/ccwd_dwr_2009.pdf. 


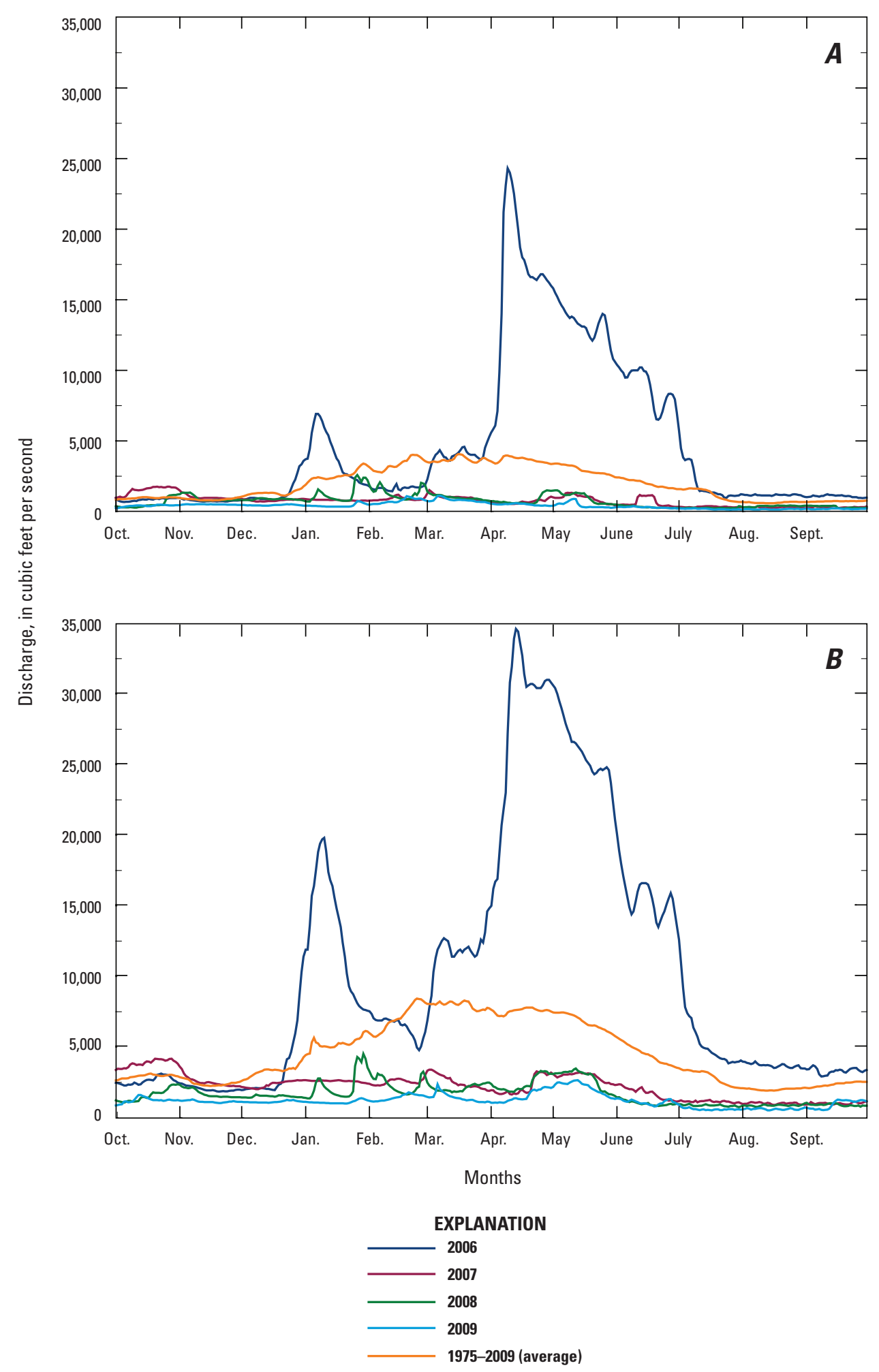

Figure 8. Mean daily flow in the San Joaquin River for the 2006-09 water years compared to long-term average of the mean daily flow for the 1975-2009 water years at the most upstream site: $A$, San Joaquin River at Newman and the most downstream site; $B$, San Joaquin Valley at Vernalis. 
Table 3. Comparison of the ranges of mean daily flows as a percentage of the long-term average of mean daily flow (1975-2009) at the most downstream site, San Joaquin River (SJR) at Vernalis, and the most upstream site, SJR at Newman, for each of the sampling approaches and sampling period.

[Daily mean flow values from given sites were obtained from U.S. Geological Survey (USGS) National Water Information System (NWIS) and Kratzer and others, 2010. Abbreviations ID, identification]

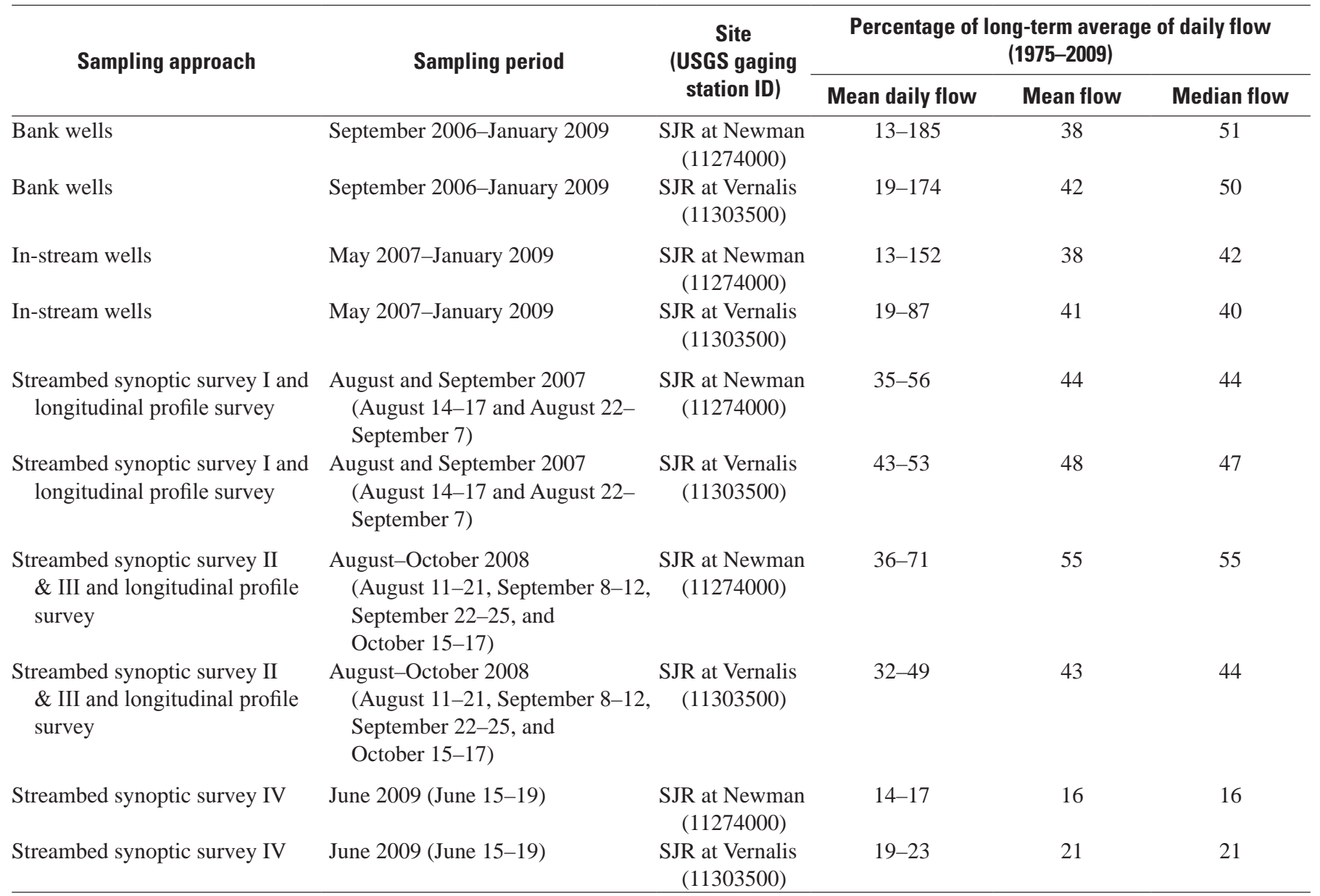

\section{Groundwater}

The elevation of the water table within and around the study area in spring 2006 is shown in figure 9. Horizontal gradients west of the SJR were 4-5 feet per mile ( $\mathrm{ft} / \mathrm{mi}$ ) and generally were greater than gradients east of the river, which were 1-4 ft/mi. The elevation of the water table west of the SJR is a subdued replica of the topography, sloping gently toward the river from the Coast Ranges. East of the river, agricultural pumpage has resulted in the formation of a groundwater divide about $12 \mathrm{mi}$ northeast of the NewmanPatterson reach. East of the divide, which is parallel to the river, the water table slopes eastward toward the cone of depression. West of the divide, the water table slopes gently toward the river.

Figure 10 depicts the weekly median levels of groundwater in the bank wells and stream stage from April 2007 through March 2009. All wells show a seasonal variation in water level to some degree, with declining water levels in the late summer and early fall and rising water levels in the late winter and spring. With the exception of the wells at the Patterson site (fig. 10C), groundwater levels were higher than the stream stage, indicating groundwater flow is toward the river. Significant pumping near the river on the west side of the Patterson site resulted in a higher median stream stage than water levels in the bank wells for the period of study. The median water-level differences between stream stage and the deep water-table well (PW-89) and shallow water-table well (PW-22.5) from April 2007 to October 2008 were 0.92 and $2.0 \mathrm{ft}$, respectively. The Patterson Irrigation District (PID) pumps groundwater from two wells approximately $0.25 \mathrm{mi}$ (PID Old Palmas Well) and 0.5 mi (PID Poplar Well) west of the bank wells. The combined estimated average pumping rates for both wells in 2007 and 2008 were approximately 4,020 and 3,830 gallons per minute (gal/min), respectively (John Sweigard, Patterson Irrigation District general manager, written commun., January 8, 2009). Peak pumping generally takes place in March during pre-irrigation, but can extend from mid-June to mid-September to meet demand. The effects of these pumping rates on water levels are shown in the hydrograph of the west-side deep well and shallow well, PW-89 and PW-22.5, respectively (fig. 10C). 


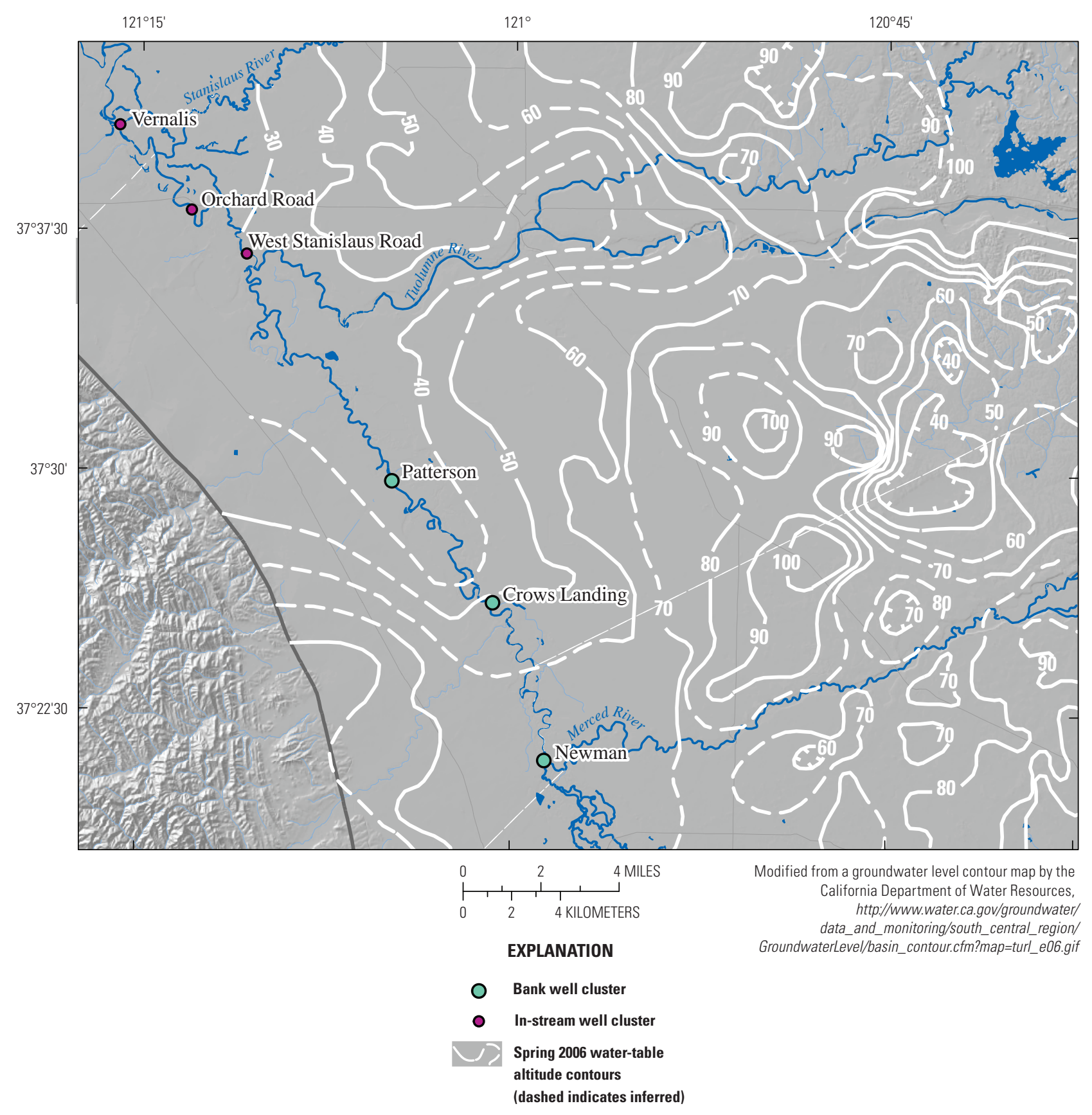

Figure 9. Water table altitude to the east and west of the monitoring well locations, spring 2006. 

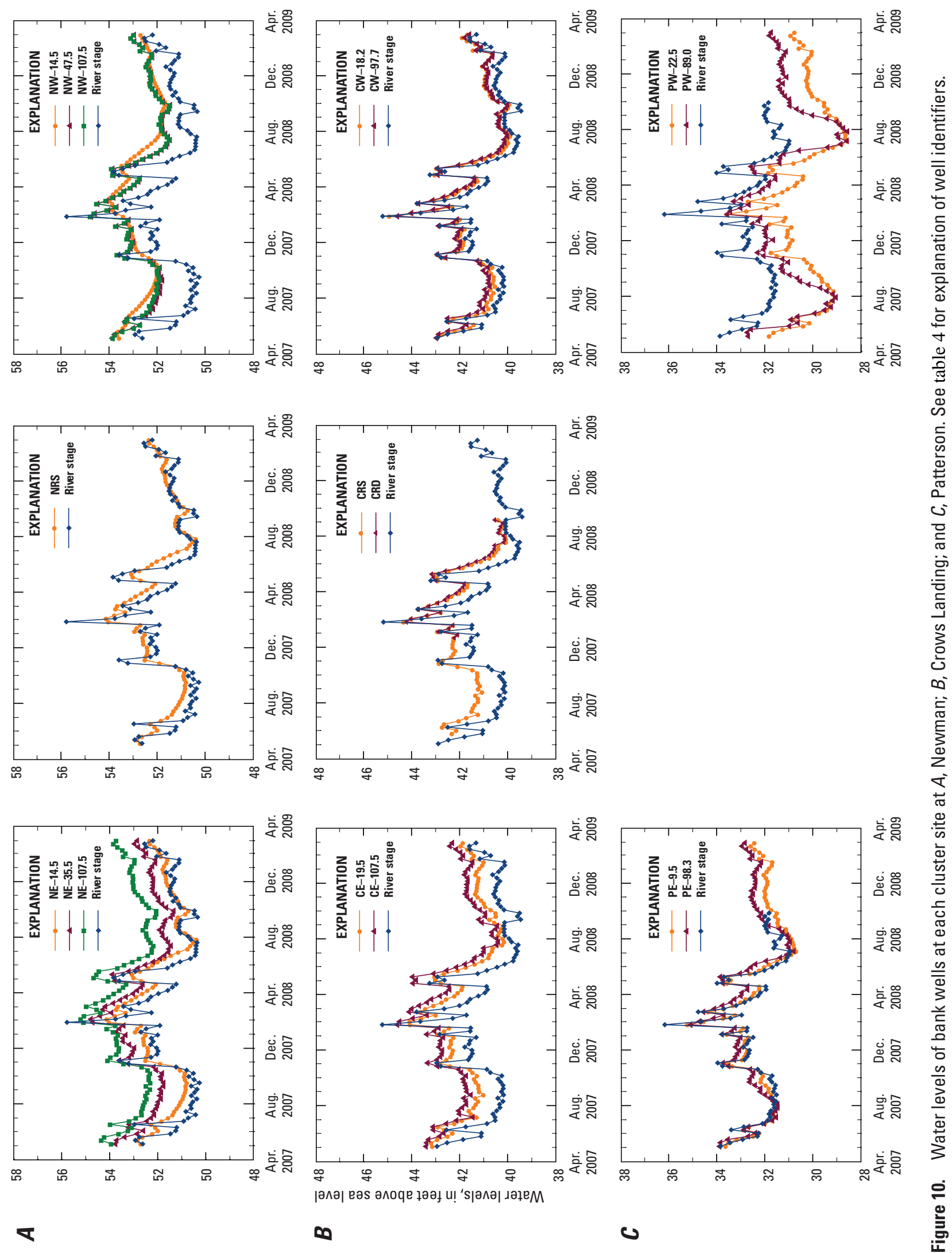
Table 4. List of well-cluster site names, well type, screened depth, well identifiers, and State well numbers.

[For bank wells, screened depth is in feet below land surface to the midpoint of the screened interval and had 2-inch diameter polyvinyl chloride casings with a 5-foot (ft) screened interval $3 \mathrm{ft}$ above the closed bottom of the casing. For in-stream wells, depth is from the streambed to the midpoint of the screened interval and had 3/8-inch stainless steel casings with a 5-ft screened interval $3 \mathrm{ft}$ above the bottom of the casing]

\begin{tabular}{|c|c|c|c|c|c|c|}
\hline $\begin{array}{l}\text { Well cluster } \\
\text { site name }\end{array}$ & $\begin{array}{l}\text { Well } \\
\text { type }\end{array}$ & Location & $\begin{array}{l}\text { Screened depth, } \\
\text { in feet }\end{array}$ & $\begin{array}{c}\text { Well } \\
\text { identifier }\end{array}$ & $\begin{array}{c}\text { State } \\
\text { well number }\end{array}$ & $\begin{array}{c}\text { River mile } \\
\text { location }^{1}\end{array}$ \\
\hline Newman & Bank well & West & 14.5 & NW-14.5 & 007S009E04J005M & 118.0 \\
\hline Newman & Bank well & West & 47.5 & NW-47.5 & 007S009E04J006M & 118.0 \\
\hline Newman & Bank well & West & 107.5 & NW-107.5 & 007S009E04J007M & 118.0 \\
\hline Newman & In-stream well & River & 29.5 & NRD & 007S009E04J008M & 118.0 \\
\hline Newman & In-stream well & River & 5.5 & NRS & 007S009E04J009M & 118.0 \\
\hline Newman & Bank well & East & 14.5 & NE-14.5 & 007S009E03M003M & 118.0 \\
\hline Newman & Bank well & East & 35.5 & NE-35.5 & 007S009E03M002M & 118.0 \\
\hline Newman & Bank well & East & 107.5 & NE-107.5 & 007S009E03M001M & 118.0 \\
\hline Crows Landing & Bank well & West & 18.2 & CW-18.2 & 007S009E07H002M & 107.3 \\
\hline Crows Landing & Bank well & West & 97.7 & CW-97.7 & 007S009E07H001M & 107.3 \\
\hline Crows Landing & In-stream well & River & 26.5 & CRD & 006S009E07A005M & 107.3 \\
\hline Crows Landing & In-stream well & River & 5.5 & CRS & 006S009E07A006M & 107.3 \\
\hline Crows Landing & Bank well & East & 19.5 & CE-19.5 & 006S009E07A001M & 107.3 \\
\hline Crows Landing & Bank well & East & 107.5 & CE-107.5 & 006S009E07A002M & 107.3 \\
\hline Patterson & Bank well & West & 22.5 & PW-22.5 & 005S008E15M006M & 98.8 \\
\hline Patterson & Bank well & West & 89.0 & PW-89.0 & 005S008E15M005M & 98.8 \\
\hline Patterson & In-stream well & River & 17.0 & PRD & 005S008E15M008M & 98.8 \\
\hline Patterson & In-stream well & River & 5.5 & PRS & 005S008E15M009M & 98.8 \\
\hline Patterson & Bank well & East & 9.5 & PE-9.5 & 005S008E15M001M & 98.8 \\
\hline Patterson & Bank well & East & 98.3 & PE-98.3 & 005S008E15M002M & 98.8 \\
\hline West Stanislaus Road & In-stream well & River & 5.5 & WRS & 004S007E10H002M & 84.1 \\
\hline West Stanislaus Road & In-stream well & River & 18.5 & WRD & 004S007E10H001M & 84.1 \\
\hline Orchard Road & In-stream well & River & 5.5 & ORS & 003S007E32A002M & 78.2 \\
\hline Orchard Road & In-stream well & River & 21.5 & ORD & 003S007E32A001M & 78.2 \\
\hline Vernalis & In-stream well & River & 21.5 & VRS & 003S006E13C002M & 72.2 \\
\hline Vernalis & In-stream well & River & 6.5 & VRD & 003S006E13C001M & 72.2 \\
\hline
\end{tabular}

${ }^{1}$ Indicates river mile location of monitoring well cluster at given site within the 59-mile study reach, see figure 15 for illustration.

A key to evaluating groundwater discharge to the river is an understanding of the distribution and variability of hydraulic gradients between the groundwater elevation and the stream stage. Horizontal hydraulic gradients near the river, vertical gradients between the deep bank wells and the shallow water-table wells, and horizontal gradients between the deep bank wells on opposite sides of the river are depicted in figures 11,12, and 13, respectively. Horizontal hydraulic gradients between shallow water-table wells and the SJR at the Newman and Crows Landing sites were generally toward the river with distinct flow reversals in November 2007, January 2008, and May 2008 (fig. 11A and 11B, respectively). At the Patterson site, the horizontal gradient was relatively weak on the east side and strongly negative on the west side because of local groundwater pumping throughout the period of record (fig. 11C).
Vertical hydraulic gradients between the deep and shallow bank wells varied from site to site and demonstrated effects of seasonal pumping and irrigation trends (fig. 12). At the Newman site, the west-side bank well exhibited flow reversals at the beginning of the irrigation season in May 2007 and 2008, followed by a relatively quick recovery as the pumped groundwater was reapplied to the surface for the irrigation of crops; however, the east-side gradient remained upward and relatively constant (fig. 12A). At Crows Landing, the gradients generally were positive and depicted an inverse pattern beginning in late October 2007, with slight flow reversals on the west side (fig. 12B). The variations in vertical gradients on the east side of the Patterson site were diminutive in comparison to the variations on the west side (fig. 12C). Effects of summer groundwater pumping from the PID can clearly be seen in 2007 and 2008. 

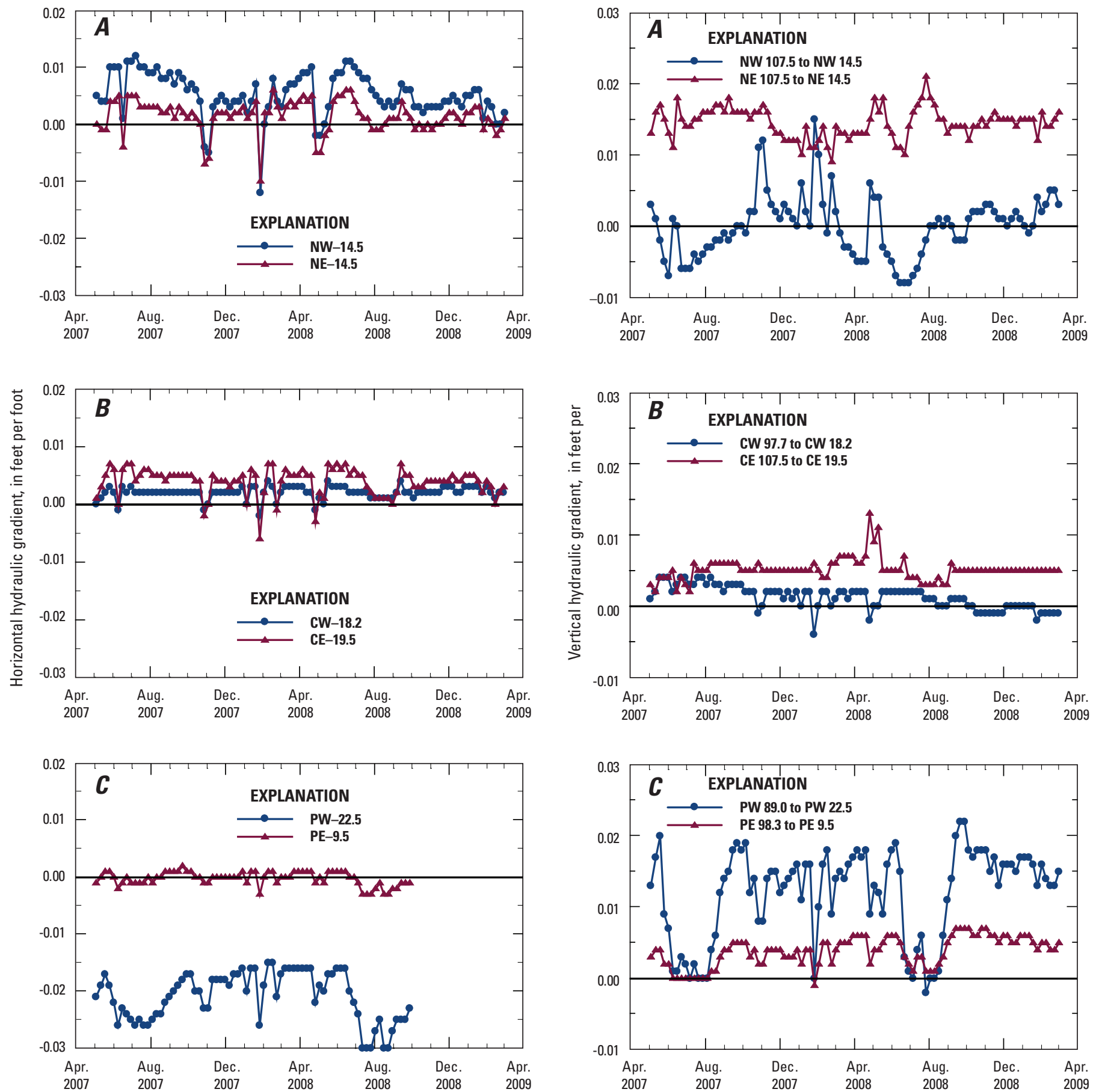

Figure 11. Horizontal hydraulic gradients between shallow bank wells and the San Joaquin River at the $A$, Newman; $B$, Crows Landing; and $C$, Patterson sites. Positive gradients indicate river gain. See table 4 for explanation of well identifiers.

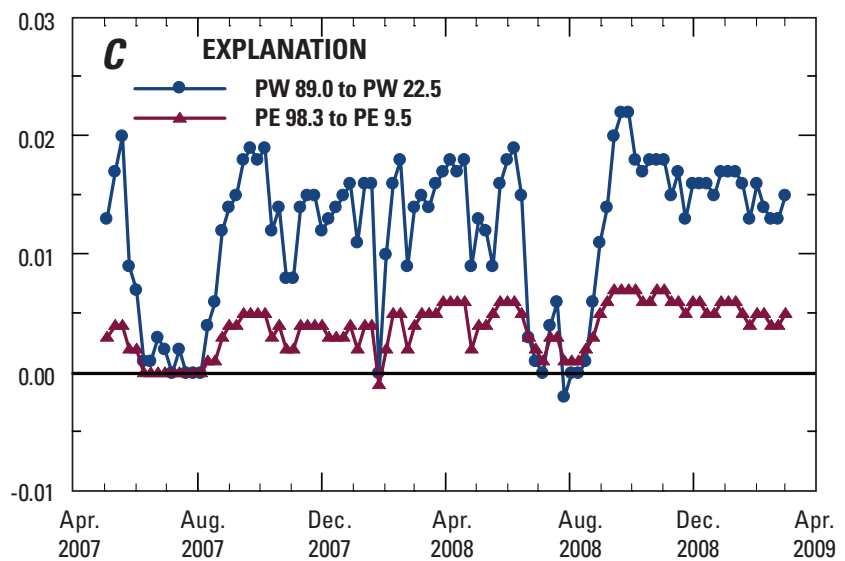

Figure 12. Vertical hydraulic gradients between deep and shallow bank wells at the $A$, Newman; $B$, Crows Landing; and $C$, Patterson sites. Positive gradients indicate river gain. See table 4 for explanation of well identifiers. 
The horizontal gradients between the deep bank wells on opposite sides of the river indicate that the flow is predominately westward for the three sites (fig. 13). The Newman bank wells (NW 107.5 to NE 107.5) exhibited one flow reversal in June 2007; that reversal is likely related to irrigation in a field adjacent to the wells on the west side of the river. Groundwater flow at the Crows Landing bank wells (CW 97.7 to CE 107.5) was almost exclusively westward, with one slight flow reversal in February 2008 during a storm event. The horizontal gradient between the deep bank wells at Patterson (PW 89.0 to PE 98.3) was exclusively westward, was the strongest of the three sites, and was most pronounced during the irrigation season in the spring and early summer of 2007 and 2008.

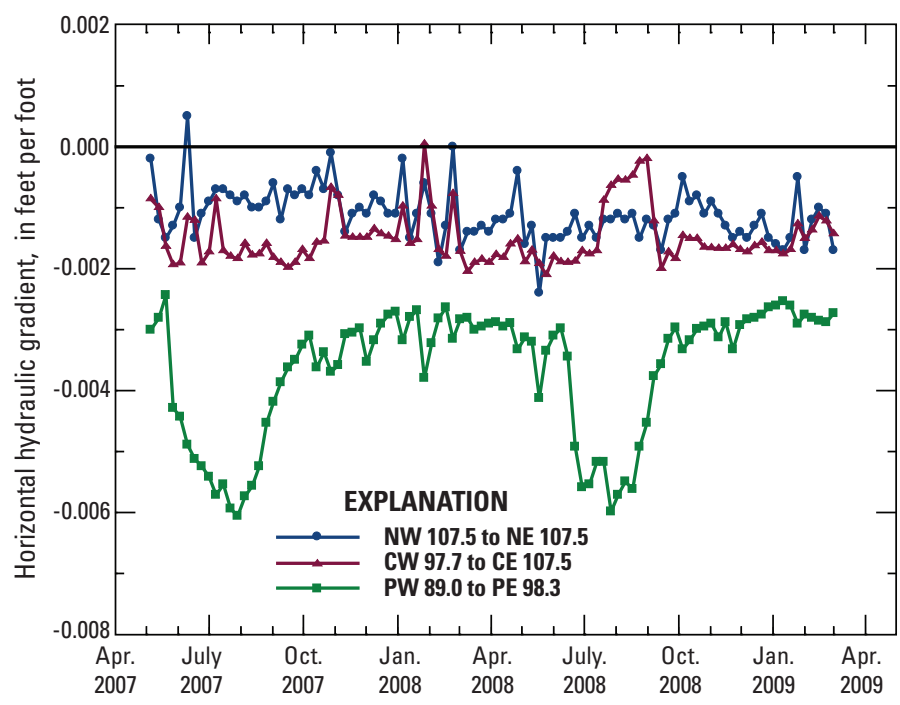

Figure 13. Horizontal hydraulic gradients between deep bank wells on opposite sides of the San Joaquin River. Negative gradients indicate an east-to-west groundwater movement. See table 4 for explanation of well identifiers.
The hydraulic gradients and the water-level hydrographs indicate that groundwater pumping has had a significant effect on the groundwater flow system near the SJR. An understanding of the distribution of pumping is an important aspect of the conceptualization of the flow system. Detailed pumpage data were not available for all sites in the study area, but groundwater withdrawal from the unconfined zone overlying the Corcoran Clay Member takes place primarily on the eastern side of the SJR, largely surrounding the urban areas of Modesto and Turlock, California (Faunt, 2009); little is known about the local and regional groundwater withdrawals on the western side (fig. 9).

A comparison of horizontal gradients between the 1988-89 and the 2006-08 study periods indicates that localized or regional west-side pumping has become significant enough to create a horizontal flow reversal between the deep wells across the river at the Crows Landing (fig. 14B), and Patterson (fig. 14C) study sites. Figure 14 depicts the historic and present median water levels at the Newman, Crows Landing, and Patterson bank well sites. Phillips and others (1991) carried out a groundwater study that examined the quantity and quality of groundwater discharging to the SJR at the same well cluster sites in 1988-89. The observed horizontal hydraulic gradients and water-level hydrographs indicated that the predominant horizontal flow direction across the river between the deep wells was eastward, contrary to the present westward horizontal flow direction at the well cluster sites.

At the Patterson site (fig. 14C), the present water levels on the east and west side were significantly lower than the stream stage. The groundwater pumping at this site results in (1) diversion of water from the natural discharge zone (the SJR) and (2) a component of groundwater flow underneath the SJR from east to west across the valley trough. The present water levels on the west side of the Crows Landing site are lower than those on the east for both the deep and shallow wells indicating the same pattern of westward horizontal flow underneath the river. At the Newman site, although the present water levels in the deep wells indicate the same westward horizontal flow pattern underneath the river, the water levels in the shallow water-table wells on the east side indicate that local or regional groundwater pumping has been significant enough to create a shallow eastward horizontal flow component underneath the river. 

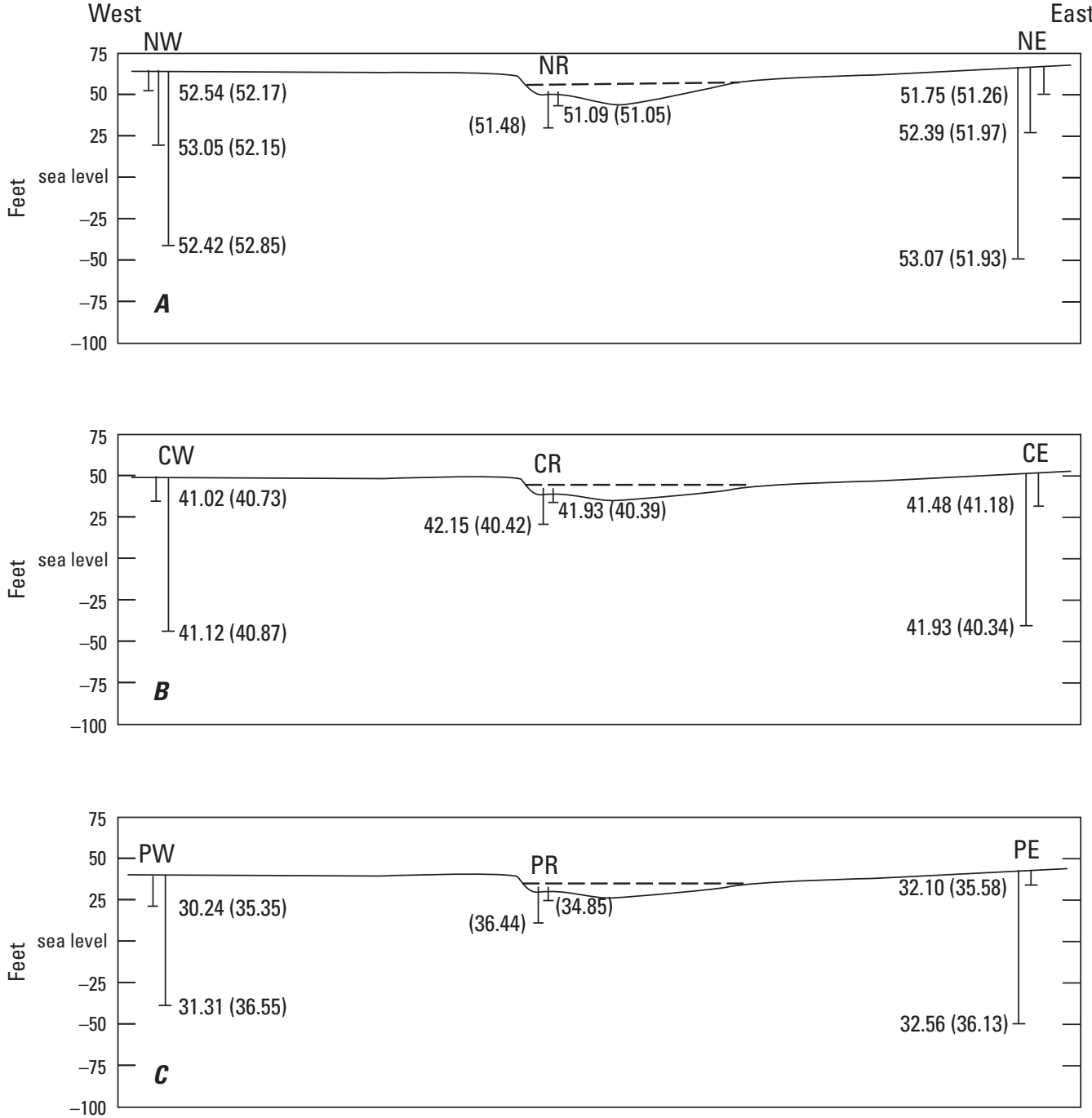

EXPLANATION

Land surface referenced to the North American Vertical Datum of 1988 (NAVD 88), approximately located between well cluster sites.

- - - San Joaquin River, approximately located

Cluster site- site at which two or more monitoring wells are installed at different depths. See table 4 for explanation of cluster site name and location.

$\perp$ Midpoint of 5-foot screened interval of individual bank well or total depth of in-stream well.

$0.81(0.05)$ Number(s) represent present and historical (in parenthesis) median water levels.

Figure 14. Median water levels in the bank wells for the 1988-89 and 2006-08 study periods: $A$, Newman site; $B$, Crows Landing site; and $C$, Patterson site. 


\section{Study Design}

This study used four approaches to characterize the rate and quality (nitrate and DOC concentration) of groundwater discharge to the SJR. The four approaches were necessary to capture the different scales of spatial and temporal variability. The first approach was to revisit monitoring wells that were installed in nests at three sites in the streambed (in-stream wells) and on both banks (bank wells) of the SJR in the late1980s (Phillips and others, 1991; fig. 15A, B, and C) and to install in-stream wells at three additional sites downstream in order to extend the length of the monitored reach (fig. 15D, $\mathrm{E}$, and $\mathrm{F}$ ). Water-quality, water-level, and temperatureprofile data collected at these sites were used to model the groundwater contribution and its associated water quality. The second approach was a streambed synoptic survey similar to that used on the lower Merced River as part of the San Joaquin National Water-Quality Assessment (NAWQA) program (Domagalski and others, 2008; Essaid and others, 2008). This approach involved sampling numerous sites between the well sites (figs. 15A-F) by using a temporarily installed drive-point piezometer to collect water samples for chemical analysis and using a manometer and a thermistor probe to evaluate hydraulic and temperature gradients below the streambed. The chemistry of the groundwater just below the streambed (less than $6 \mathrm{ft}$ ) was used to interpret biogeochemical processes occurring within the streambed and to assess fluxes to the surface water. The third approach was longitudinal profile surveys by boat that involved continuously measuring the water temperature, SC, nitrate, and optical properties (DOC and estimated chlorophyll- $\alpha$ concentration) of river water just above ( 0.5 to $1 \mathrm{ft}$ ) the streambed from a boat moving down the study reach. These longitudinal profile surveys were used in an attempt to identify differences in water quality or temperature that could indicate areas of groundwater discharge to the river.

The fourth approach was modeling to estimate groundwater discharge to the river by using the continuous water-level and temperature data collected from the bank wells and in-stream wells at the well sites (figs.15A-F) by using two numerical modeling methods. The first modeling method applied the water-level data collected from the bank wells to the USGS modular finite-difference groundwater flow model, MODFLOW (Harbaugh and others, 2000). Twodimensional, steady-state groundwater flow models were created with MODFLOW to estimate groundwater discharge to the SJR at each well site that had bank wells (sites A, B, and C). The second modeling method applied the water-level and streambed temperature data collected from the in-stream wells to the USGS numerical model, VS2DH (Healy and Ronan, 1996). One-dimensional modeling of heat and water flow (vertical streambed flux) with VS2DH was used to estimate groundwater exchange rates with the SJR and streambed conductance values at each of the in-stream monitoring well sites (sites D, E, and F).
An understanding of the terminology used to describe the exchanges at the streambed interface between surface water and groundwater in this report is presented in a conceptual model. Figure 16 depicts a conceptual model of a gaining stream reach, losing stream reach, and a neutral stream reach. For the case of a gaining stream reach (fig. 16A), the hydraulic gradient is upward (higher total head beneath the stream than in the stream), as indicated by the higher elevation of water in the in-stream monitoring well compared to the stream stage (measured by the stream gage). This scenario is referred to as "river gain" or groundwater discharge - that is, groundwater discharging into the river at the streambed interface. For the case of a losing stream reach (fig. 16B), the hydraulic gradient is downward (lower total head beneath the stream than in the stream), and stream water leaves through the streambed and enters groundwater flow system. This scenario is referred to as "river loss." For the case of a neutral stream reach (fig. 16C), the hydraulic head is zero (the total head beneath the stream and in the stream are equal) and no river gain or river loss occurs. The general surface-water and groundwater exchanges at the streambed interface are referred to as streambed flux.

\section{Monitoring Wells Approach}

Nested monitoring wells in the streambed (in-stream wells) and on both banks (bank wells) at three sites (figs 15A, $B$, and C) along the SJR were used by Phillips and others (1991) in the late-1980s to model groundwater contribution to the lower SJR. The current study extended that approach by adding three downstream sites (fig. 15D, E, and F) to collect data needed to model the vertical heat transport in the streambed. The data collected at the six sites were used to simulate groundwater contributions and their associated water quality and to compare results to values from the late-1980s.

Although extensive effort was put forth to rehabilitate the existing bank wells (fig. 15A, B, and C) from the Phillips and others (1991) study, only 14 of these 16 existing bank wells were functional for sampling. The shallow bank wells located on the west bank at the Crows Landing and Patterson sites could not be restored (rehabilitated). New in-stream wells were installed at the three existing sites and at three new downstream sites (fig. 15A-F).

Groundwater quality data collected from the bank wells and in-stream wells were used to estimate nitrate and DOC concentrations in groundwater. Pressure transducers continuously monitored groundwater levels in the bank wells and the in-stream wells from May 2007 through December 2008 for bank wells and through January 2009 for the in-stream wells. Because of pressure transducer malfunctions with the in-stream wells, no water levels were recorded for the period of study at the Patterson site (fig. 15C) and for the deep in-stream well at the Newman site (fig. 15A). A partial record of water-level data was collected for the deep in-stream well at the Crows Landing site (fig. 15B). 

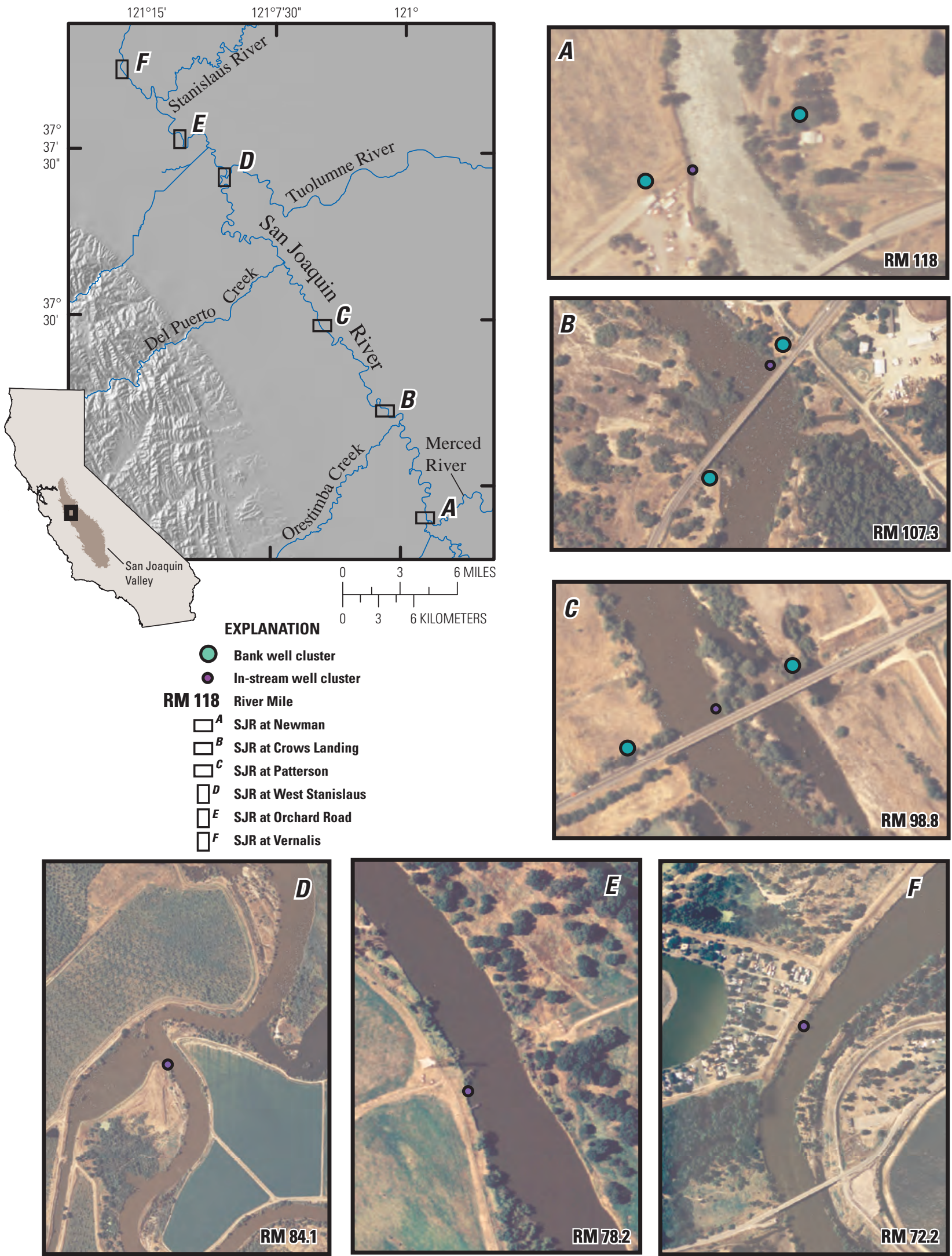

Figure 15. Well cluster sites at six locations along the San Joaquin River (SJR). 

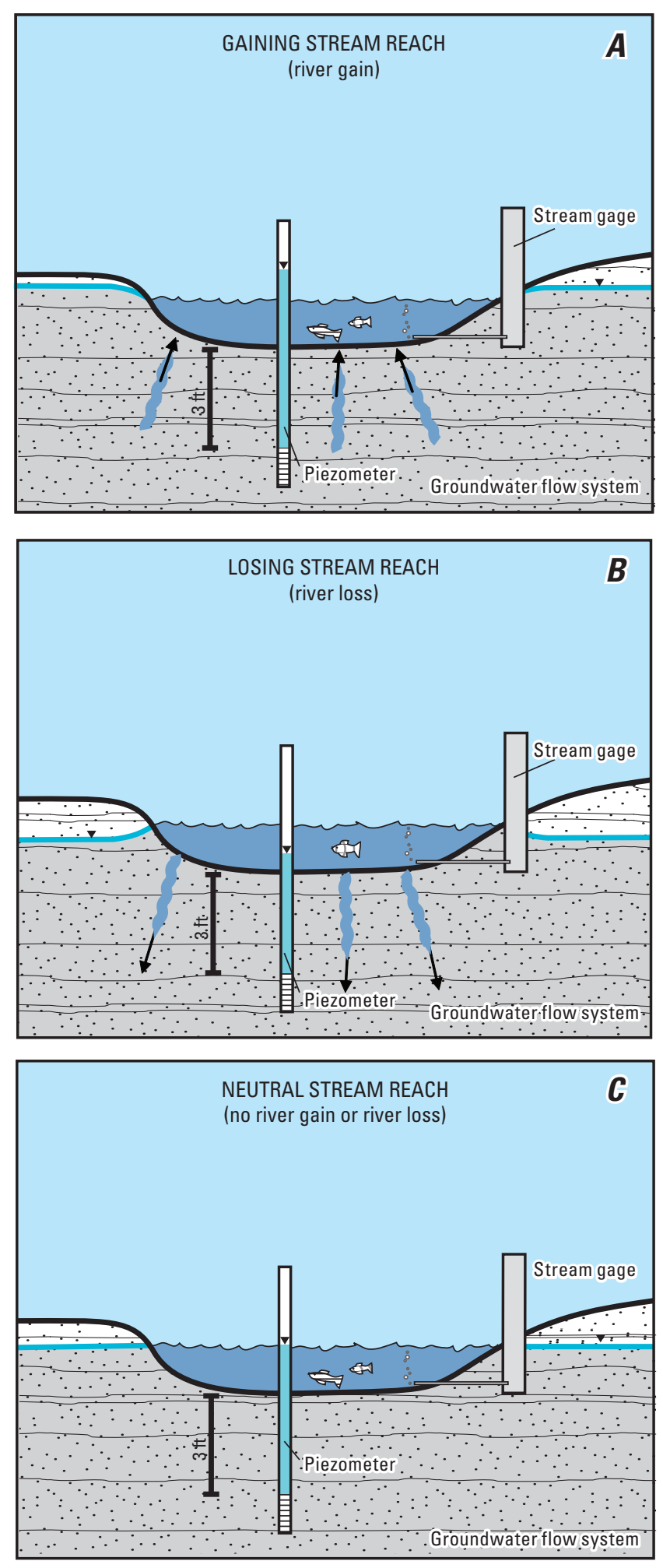

Figure 16. Conceptual mode of scenarios of $A$, gaining stream (river gain); $B$, losing stream (river loss); and $C$, neutral stream (no river gain or loss) that occur during surface-water and groundwater exchanges.
Temperature was continuously monitored at each of the in-stream well sites. Temperature sensors collected data in the surface water (approximately $0.5 \mathrm{ft}$ above the streambed) and at five depths below the streambed $(0.5,1.0,1.5,3.0$, and $6.0 \mathrm{ft}$ ) in the deep in-stream wells. Water-level and temperature data were collected at 30-minute intervals throughout the data collection period for the bank and in-stream wells.

\section{Streambed Synoptic Survey Approach}

In this study, synoptic sites were used to provide data on hydraulic and temperature gradients and groundwater quality for transects that crossed the river between the six well sites. The desired outcome of this approach was to fill spatial gaps for water-quality and hydrologic data and to allow extrapolation of results from the other two approaches to the entire 59-mi study reach. The streambed synoptic survey approach used in this study was developed in previous NAWQA studies on the Merced River (Domagalski and others, 2008; Essaid and others, 2008). Those studies used synoptic measurements of hydraulic gradients, temperatures above and below the streambed, and nitrate and dissolved oxygen concentrations below the streambed to provide better spatial coverage around established sites for a study of groundwater/surface-water interactions.

Synoptic measurements were made at a total of 113 individual transects during 4 sampling events (August-September 2007, August 2008, September 2008, and June 2009). The sampling at each transect included measurements of hydraulic gradients, temperatures above and below the streambed, field measurements of groundwater quality (temperature, $\mathrm{pH}, \mathrm{SC}$, and dissolved oxygen), and laboratory measurements of nitrate and DOC concentrations in groundwater. Water samples were obtained by use of a temporary drive-point piezometer and a peristaltic pump that could be moved from site to site. These synoptic sampling measurements provided spatial coverage between the six well sites, but did not provide the temporal coverage of the study area during multiple seasons.

\section{Longitudinal Profile Survey Approach}

The longitudinal profile surveys by boat added continuous measurements of water-quality parameters that could indicate potential groundwater sources. Three times during the study period-August 2007, September 2008, October 2008-continuous longitudinal water-quality measurements were made along the 59-mi study reach of 
the SJR. These water-quality measurements coincided with the first three synoptic surveys described previously. This approach was used to locate areas of cooler water entering the stream from the ground, either along the streambed or the stream bank. This method is described in Vaccaro and Malloy (2006) and has been applied to studies of groundwater and surface-water interactions (U.S. Environmental Protection Agency, 2000). In a U.S. Environmental Protection Agency (USEPA) sponsored workshop on groundwater and surfacewater interactions in 1999, the approach was referred to as "sediment probes" or "drag probes" in a scientific paper and in two summary sessions on available methods (U.S. Environmental Protection Agency, 2000). John Vaccaro of the USGS Washington Water Science Center identified areas of cool groundwater discharging into the Yakima River Basin by using this approach with temperature and SC probes (John Vaccaro, Hydrologist, U.S. Geological Survey, written commun., 2005). Previous studies have demonstrated that groundwater and dairy-runoff could be identified in the river by using a combination of these measurements (Lee, 1985; Harvey and others, 1997; U.S. Environmental Protection Agency, 2000; Bergamaschi and others, 2005; John Vaccaro, Hydrologist, U.S. Geological Survey, written comm., 2005).

Longitudinal profile surveys were used to help identify potential sites for synoptic sampling and to increase the spatial resolution of measurements of groundwater sources. Identification of anomalous physio-chemical measurements in the water column collected in a Lagrangian frameworkmoving at the same velocity as a parcel of water-were used as qualitative and quasi-quantitative measurements of groundwater contribution between the in-stream monitoring wells and points measured during the streambed synoptic surveys in the study area.

Longitudinal profile surveys were also used to locate, identify, and quantify nitrate contributions and to provide physio-chemical measurements useful in the identification of surface-water inflows to the SJR. A variety of sensors designed to measure physical (temperature, SC, dissolved oxygen, and turbidity) and chemical ( $\mathrm{pH}$, dissolved organic matter, nitrate) water-quality constituents were used in the longitudinal profile surveys. Optical sensors designed to measure absorbance and fluorescence were used to detect chemical differences in groundwater inputs at the streambed as described by Downing and others (2009). Optical property measurements were also used to identify bulk changes in the dissolved organic matter (DOM) pool which can relate to changes in contributions of DOM and nutrients from localized areas of groundwater discharge.

\section{Modeling Approach}

The water-level data collected from the bank wells were used for the modeling of groundwater exchange rates with the SJR by using the USGS modular finite-difference groundwater flow model, MODFLOW (Harbaugh and others, 2000). The measured water-level and temperature data collected from the in-stream wells were used to apply to the heat-as-a-tracer method (Stonestrom and Constantz, 2003; Constantz, 2008). Groundwater exchange rates and estimates of streambed conductance values were quantified by using the USGS numerical model, Variably Saturated Two-Dimensional Heat (VS2DH; Healy and Ronan, 1996), and its graphical interface VS2DI (Hsieh and others, 2000).

\section{MODFLOW Model}

Two-dimensional, steady-state groundwater flow models were created to estimate groundwater discharge to the SJR well sites that have bank wells (fig. 15A, Newman site; 15B, Patterson site; and 15C, Crows Landing site). The threedimensional groundwater flow equation used by MODFLOW was reduced to a two-dimensional flow equation by setting the $\mathrm{x}-\mathrm{y}$ dimension parallel to the SJR to $1 \mathrm{ft}$. These flow models represent vertical cross sections orientated perpendicular to the river at each of the well sites. Models were calibrated to the difference between the yearly median groundwater levels in the monitoring wells and yearly median stream stage for each site by adjusting the recharge and discharge on the east and west facies of the model (representing east and west banks of the SJR). The modeling approach, textural information, and boundary conditions were the same as those used in a previous study at the same sites by Phillips and others (1991).

\section{VS2DH Model}

VS2DH uses an energy transport approach by way of the advection-dispersion modfloion to simulate the transport of heat and water. One-dimensional modeling of heat and water flow was used to interpret the temperature and waterlevel observations and estimate the streambed flux rates and streambed conductance values at each of the in-stream monitoring well sites. This inverse modeling method uses a visual best fit and is most sensitive to variations in the input parameter K (hydraulic conductivity). Estimates of streambed hydraulic conductivity and streambed thermal conductivity values from the literature were input into the model until the model simulations fit (matched reasonably well) observed subsurface streambed temperatures. 


\section{Methods}

The sample collection methods, laboratory analytical methods, and modeling methods used in this study are presented in this section.

\section{Sample Collection Methods}

Water-quality samples were collected from the bank and in-stream monitoring wells, from a temporarily installed drive-point piezometer during four streambed synoptic surveys, and during each of the three longitudinal profile surveys. The methods of each approach are presented separately. With the exception of DOC sample collection and processing, field measurements, sample collection, and sample processing followed protocols published in the USGS National Field Manual for the Collection of Water-Quality Data (U.S. Geological Survey, 2006). DOC samples were acidified with hydrochloric acid $(\mathrm{HCl}$; sample collection dates September 2006-June 2008) and nitric acid ( $\mathrm{HNO}_{3}$; sample collection dates July 2008-January 2009), rather than sulfuric acid $\left(\mathrm{H}_{2} \mathrm{SO}_{4}\right)$. DOC samples were collected in a pre-cleaned Nalgene HDPE (high-density polyethylene) bottle before they were poured into a baked amber glass bottle, rather than directly into the amber glass bottle (Bird and others, 2003).

\section{Monitoring Well Sample Collection}

Monitoring wells located along the banks of the SJR (fig. 15A, B, and C; table 4) associated with the previously established transects (Phillips and others, 1991) were rehabilitated, developed, and instrumented with continuous water-level sensors. These monitoring wells were sampled on an approximately monthly schedule from September 2006 until December 2008 (20 sampling dates). Paired monitoring wells were installed at a shallow (less than $6.5 \mathrm{ft}$ ) and deep (between 17 and $29.5 \mathrm{ft}$ ) depths below the streambed at all six sites. These in-stream wells were also instrumented with continuous water-level and temperature sensors that collected streambed temperatures at $0.5,1.0$, 1.5 , and $3.0 \mathrm{ft}$ below the streambed. An in-stream well and the associated instrumentation shelter are illustrated in figure 17. Approximately monthly sampling of the in-stream monitoring wells was performed from May 2007 to January 2009 (20 sampling dates). For each sampling date, water samples were collected from the bank and in-stream wells for determination of SC, nutrients (nitrate, nitrite, and ammonium), and DOC. The sampling of the bank and in-stream wells is illustrated in figure 18.

Prior to sampling a bank well, the depth to water from a reference point marked on the well casing was measured by using an electronic water-level recorder and was recorded to the nearest $0.01 \mathrm{ft}$. After the water level was recorded, the well was pumped (purged) by using an Amazon or Congo submersible pump for 1 hour (deep wells), 40 minutes (intermediate-depth wells), and 20 minutes (shallow wells). At a typical pumping rate of 1-2 gallons per minute (gal/min), these times were more than sufficient to remove 3 well-casing volumes of water prior to collection of field data and water for laboratory analyses.

A model-556 YSI multi-parameter sonde (YSI Inc., Yellow Springs, Ohio) was used to measure field temperature, $\mathrm{SC}, \mathrm{pH}$, dissolved oxygen concentration, and oxidationreduction potential. The sonde was calibrated for each parameter at the beginning of each day and periodically verified throughout the day, according to procedures in the vendor's manual. For $\mathrm{pH}$, this calibration was performed by using two buffers ( $\mathrm{pH} 4$ and $\mathrm{pH}$ 7). The buffer $\mathrm{pH}$ at the calibration temperature (reported by the buffer manufacturer) was used for the calibration. After the well was purged, a closed flow-through cell was attached to the pump tubing to prevent contact between water and the atmosphere. After the readings stabilized, at least five readings of each parameter were recorded at 1-minute intervals to verify that stable readings were achieved for each parameter.

After the field parameters were measured, the pump tubing was connected directly to an aluminum filter housing containing a glass-fiber filter (Advantec 170-millimeter diameter, about 0.3 -micrometer nominal pore size; baked in a muffle furnace at 450 degrees Celsius overnight to remove organic compounds) and into a 1-liter (L) bottle (Nalgene HDPE). This bottle was rinsed several times with filtered water and filled for distribution to bottles for different chemical analyses. All samples were filtered and chilled on ice until they could be refrigerated upon return to the laboratory. Filtered samples for DOC were acidified to prevent potential DOC removal by adsorption to iron precipitate formed as dissolved ferrous iron oxidized.

The in-stream wells had dedicated pumps installed in them, and therefore the sampling procedures differed slightly. Because of the small well diameter ( 0.75 inch) and the low flow rate, samples were collected after purging about $0.5 \mathrm{~L}$. If there was sufficient flow after purging, water was pumped through the aluminum filter apparatus with the Advantec glass-fiber filter described above into a 1-L sampling bottle (Nalgene HDPE) for subsequent distribution to the appropriate sample bottles. After sampling was completed, water was pumped through a small flow-through device to collect field measurements. Field measurements were recorded for five measurements at 1-minute intervals from the in-stream wells. In some cases, insufficient water was collected to obtain field measurements in the flow-through cell. In these cases, measurements were either taken from a single aliquot in the field, or measurements of $\mathrm{pH}$ and $\mathrm{SC}$ were determined in the laboratory. 

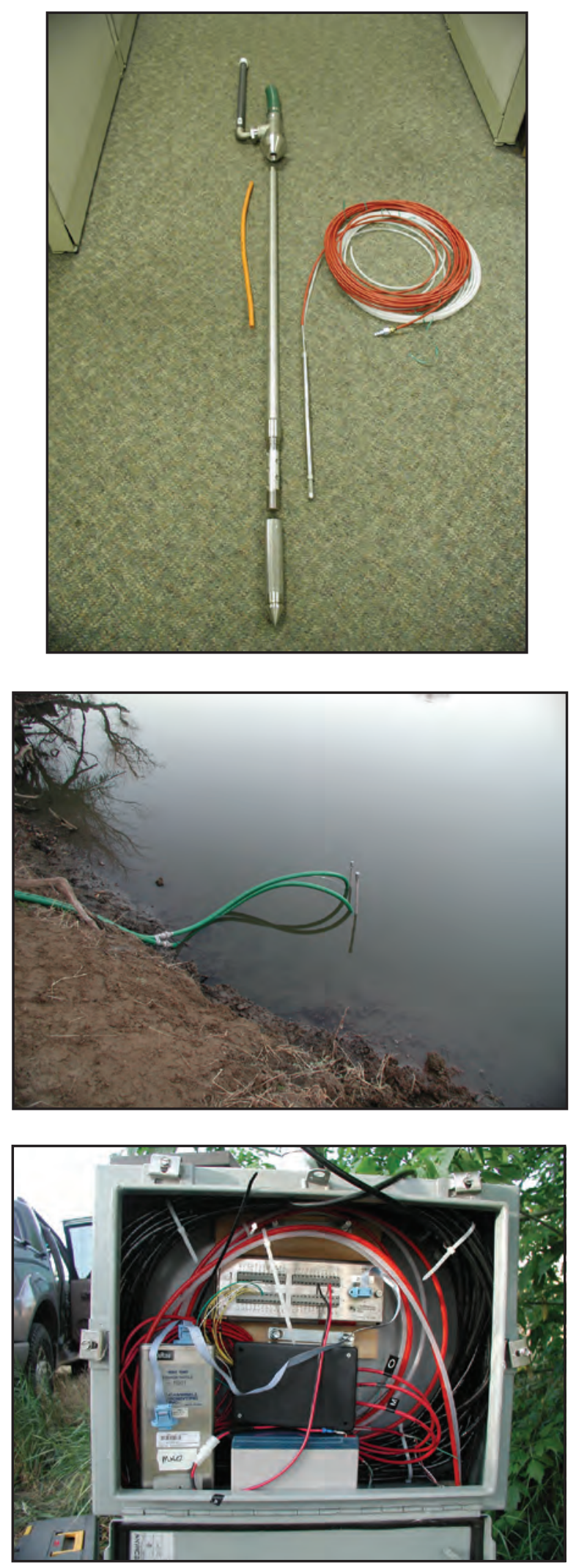

Figure 17. In-stream well at the San Joaquin River at Orchard Road site before installation (top), after installation (middle), and the data logging equipment and water-quality sampling tubing housed in the instrumentation shelter (bottom). Photograph by Peter Dileanis, U.S. Geological Survey.
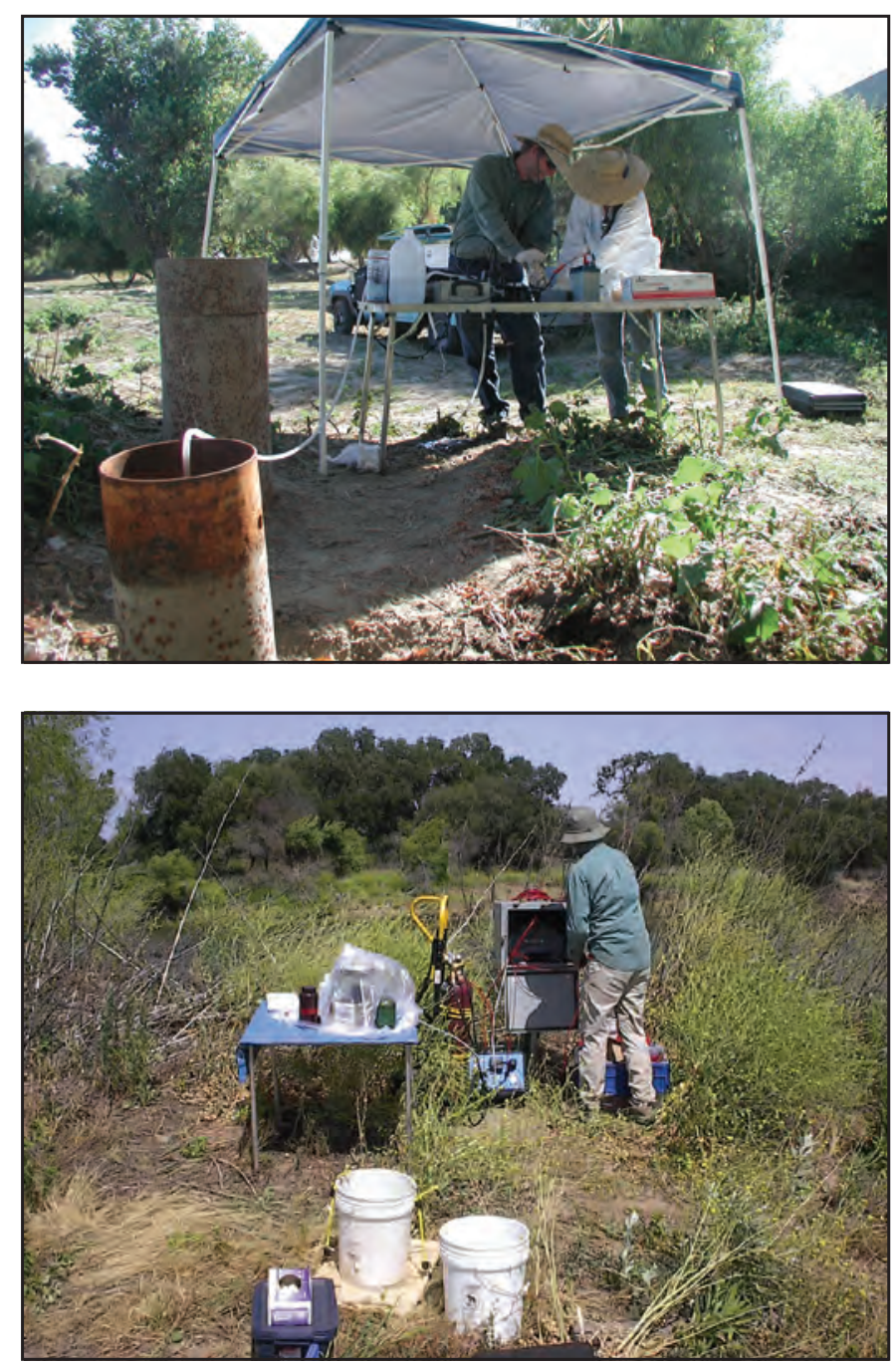

Figure 18. Water-quality sampling of a bank well (top) and an in-stream well (bottom). Photograph by Peter Dileanis, U.S. Geological Survey.

\section{Streambed Synoptic Survey Sample Collection}

Four times during the study period, synoptic measurements of streambed hydraulic gradients, streambed temperature, and streambed water-quality samples were collected by using a drive-point piezometer temporarily installed at sites orientated along transects perpendicular to flow within the 59-mi study reach of the SJR. Water-quality samples were analyzed in the field for temperature, SC, dissolved oxygen, and $\mathrm{pH}$, and in the laboratory for nitrate, ammonium, and DOC. Measurements in cross-sectional transects (1, 3, or $6 \mathrm{ft}$ below the streambed) were made at 113 sites in the study area in order to fill spatial gaps of hydrologic data and water-quality data. Although this method allowed for better spatial coverage than the six monitoringwell sites, it did not provide the temporal coverage of the well sites. This approach, coupled with the longitudinal profile survey data, allowed for an improved understanding of measured streambed and surface water-quality parameters for the entire study reach. 
Measurements of vertical hydraulic gradients were made by using drive-point piezometers with a water manometer board (Winter and others, 1988). The piezometers, 1 to 3 meters $(\mathrm{m})$ in length, were constructed of 0.95-centimeter (cm; 3/8-inch) diameter stainless-steel tubing with 2 by $0.04 \mathrm{~cm}$ slotted screens cut into the tubing just above the sharpened tip. The piezometers were hand-driven to their specified depths in the riverbed $(1,3$, or $6 \mathrm{ft}$ below the streambed), and were developed with a peristaltic pump until the water ran clear of suspended sediment. A manometer board was mounted on a stake positioned near the piezometer and perpendicular to the water surface. One tube of the manometer board was then connected with thick-walled flexible tubing to the piezometer and the other tube connected to a gravelpacked manifold just above the streambed. Water was pumped from both manometer tubes until the water columns were free of gas bubbles and then opened to atmospheric pressure. Once the height of the two water columns stabilized, the head difference, in centimeters of water, between the piezometer and the bottom of the open channel of the river was read directly from a scale mounted beside the tubes. Sometimes the manometer got clogged by the very fine-grained sediments or by bubbles from the gases in the water. If measurements could not be made at a desired depth, additional attempts were made after the piezometer was moved slightly to a shallower or deeper depth or moved a foot or two laterally along the transect.

After hydraulic gradient measurements were completed, water was pumped directly from the peizometer through a length of silicon tubing to a boat or raft used as an instrument work platform. Field measurements were recorded as the piezometer was continuously pumped by using a multiparameter water-quality monitor (YSI, Inc., model 556) mounted in an in-line flow-through chamber. The waterquality monitor was calibrated each day before measurements were made. Following field measurements, the flow-through chamber was disconnected from the sampling line, and filtered water samples were collected for laboratory analysis. Samples were filtered through a 0.45 -micrometer $(\mu \mathrm{m})$ glassfiber filter mounted in-line or through disposable capsule polyethersulfone filters mounted on polyethlene syringes. Samples for phosphous and DOC analysis were acidified in the field to a $\mathrm{pH}$ less than 2 with concentrated $\mathrm{HCl}$ (sample collection dates September 2006-June 2008) or concentrated $\mathrm{HNO}_{3}$ (sample collection dates July 2008-January 2009), and all samples were held on ice until delivered to the laboratory by courier the next morning. Field measurements were also made for surface water at the midpoint of the channel at each transect by pumping water from a drive-point tube positioned with its screened intake about $5 \mathrm{~cm}$ above the riverbed. The sampling process during the streambed synoptic surveys is illustrated in figure 19.
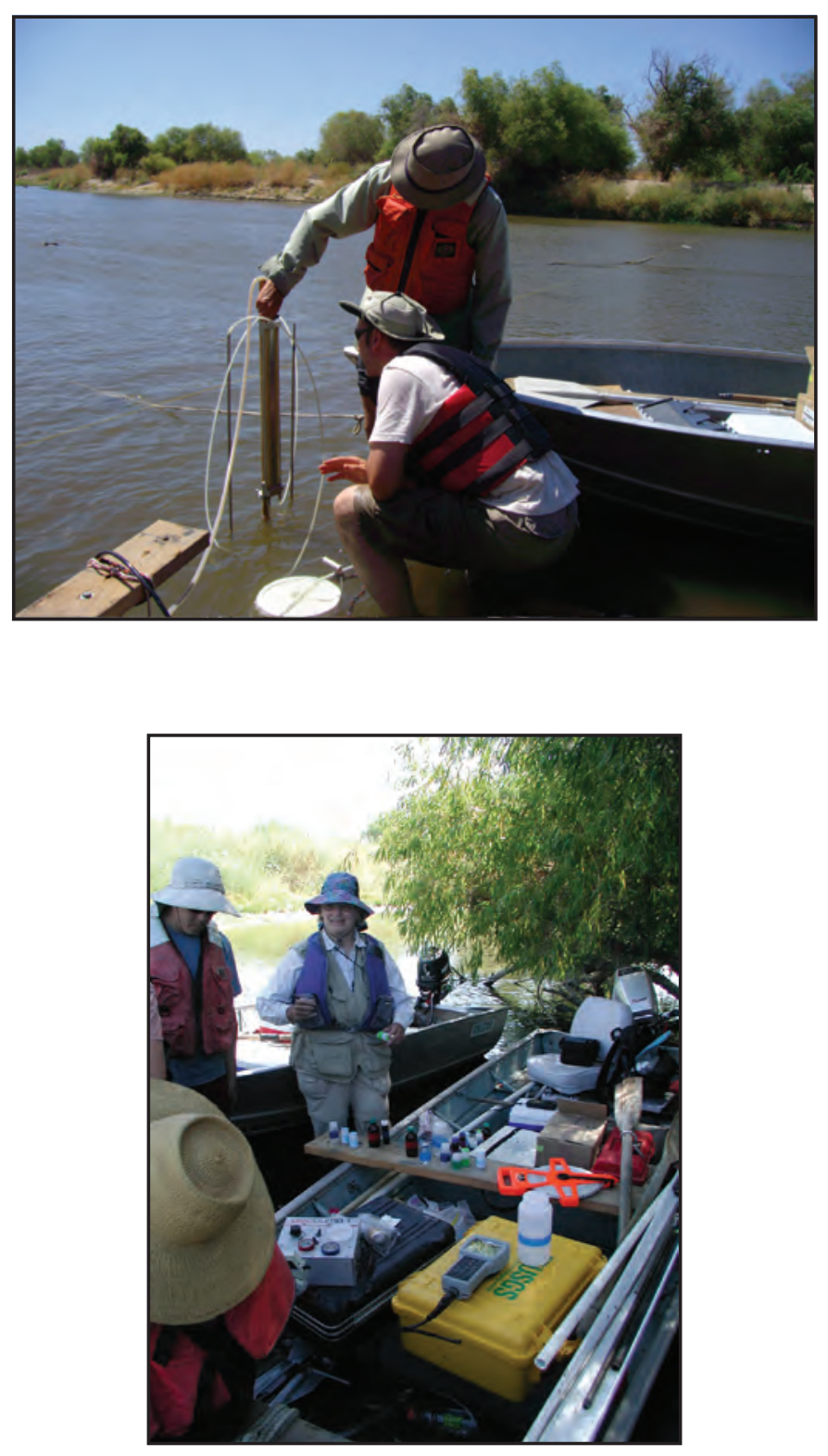

Figure 19. Measurement of hydraulic gradient made by using a manometer board (top) and the various equipment used to collect samples during the streambed synoptic surveys (bottom). Photograph by Peter Dileanis, U.S. Geological Survey. 


\section{Synoptic I-August-September 2007}

The focus of the first synoptic (August 22-30 and September 5-7, 2007) was to gain an overall understanding of the hydraulic gradients between the SJR and the shallow groundwater. Hydraulic gradients, streambed temperatures, and water-quality parameters were measured at 30 transects (river miles 131.5 to 72.0 ; fig. 20). Measurements were made from the east bank at 20 percent and 80 percent (west bank) of the total transect distance at two depths below the streambed
(1 and $3 \mathrm{ft}$ ) for a total of 120 measurements (30 transects, with 2 depths and 2 horizontal positions in each transect). With the exception of the area near the storage pond for the City of Modesto wastewater-treatment plant (WWTP), the average distance between the transects was 2.3 river miles. Measurements were made in five transects adjacent to the WWTP ponds and fields in which the treated water is applied (river miles 96.0 to 93.5) to examine areas of potential positive hydraulic gradients (river gain) and differences in SC and nutrients.

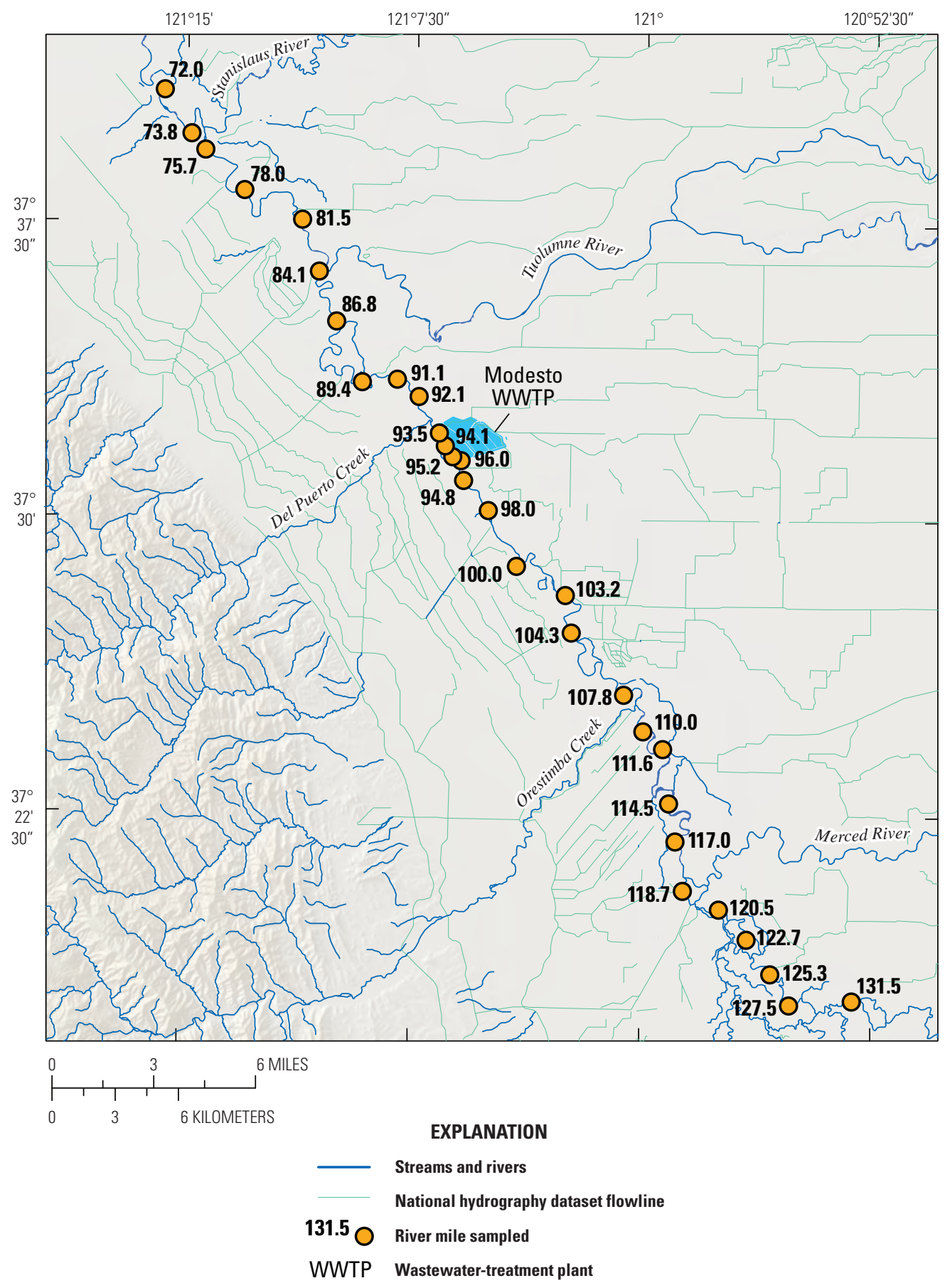

Figure 20. Sites sampled (river miles) during Synoptic I, August-September 2007. 


\section{Synoptic II-August 2008}

In the second synoptic (August 12-14, and 18-21, 2008) a total of 30 transects (11 new transects and 19 repeat transects) were measured (fig. 21). Measurements were made from the east bank at 20 percent, 50 percent (midpoint), and 80 percent (west bank) of the total transect distance at two depths below the streambed ( $1 \mathrm{ft}$ and about $6 \mathrm{ft}$ ). There were 180 measurements (30 transects, with 2 depths and 3 horizontal positions in each transect). The emphasis of this synoptic was to revisit five areas of interest found during Synoptic I. The areas of interest included transects with the highest upward hydraulic gradients (river miles 118.7, 110.0, and 91.1), areas with unexpectedly high SC (river mile 84.1), and revisiting the transects surrounding the WWTP.

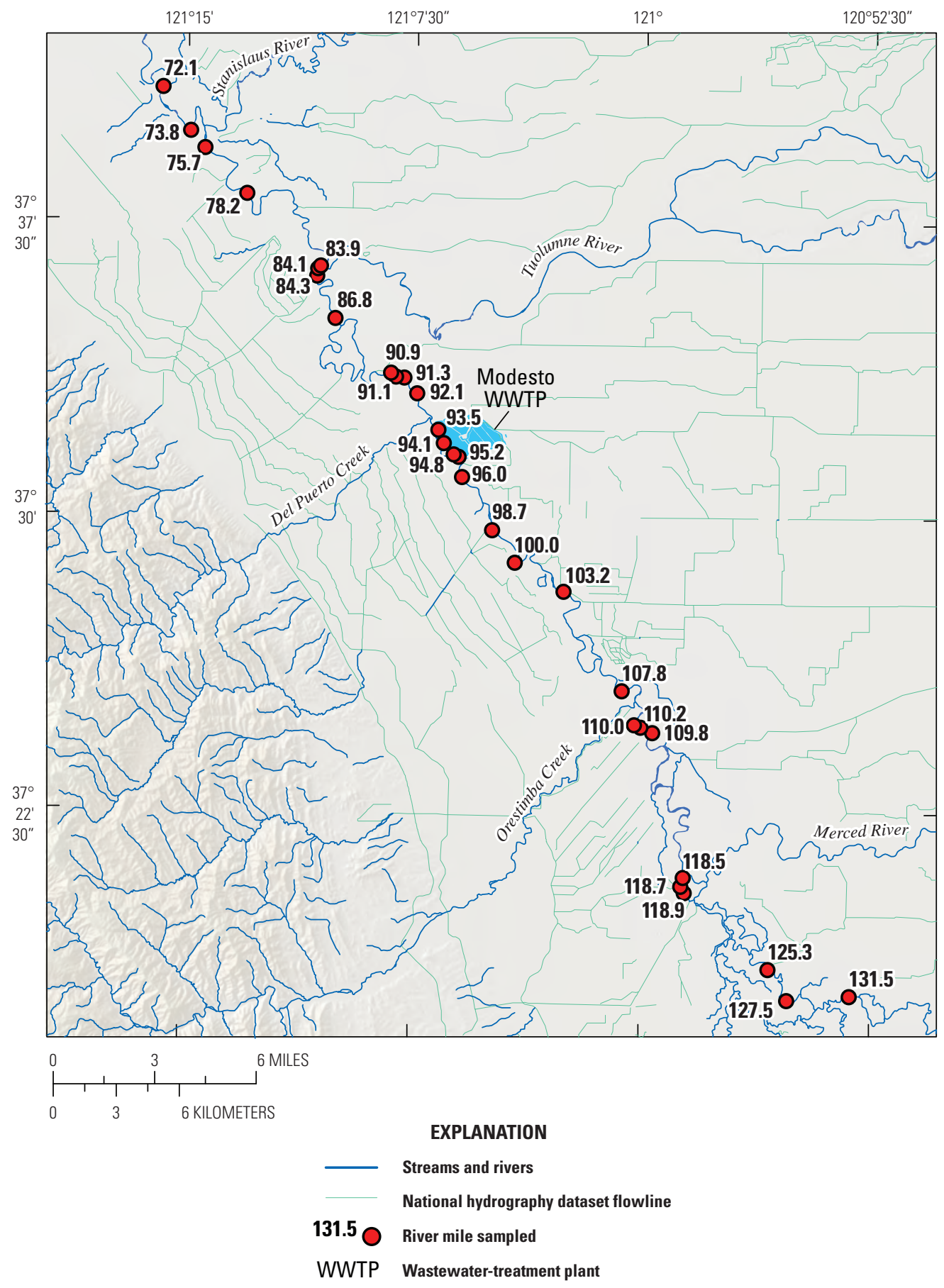

Figure 21. Sites sampled (river miles) during Synoptic II, August 2008. 


\section{Synoptic III—September 2008}

The focus of the third synoptic (September 22-25, 2008) was to examine longitudinal variability in the areas upstream and downstream of the six fixed sites. A total of 27 transects (20 new transects and 7 repeat transects) were measured (fig. 22). Transect measurements were made at each of the fixed sites, at two transects upstream, and at two transects downstream from each of the fixed sites. Measurements were made at the midpoint (50 percent distance) of each transect, at two depths ( 1 and about $6 \mathrm{ft}$ ). There were 54 measurements (27 transects, 2 depths, 1 location across a transect). Transect measurements could not be made at river miles 107.2, 107.1, and 72.2 because of deep water conditions that prevented wading across the river.

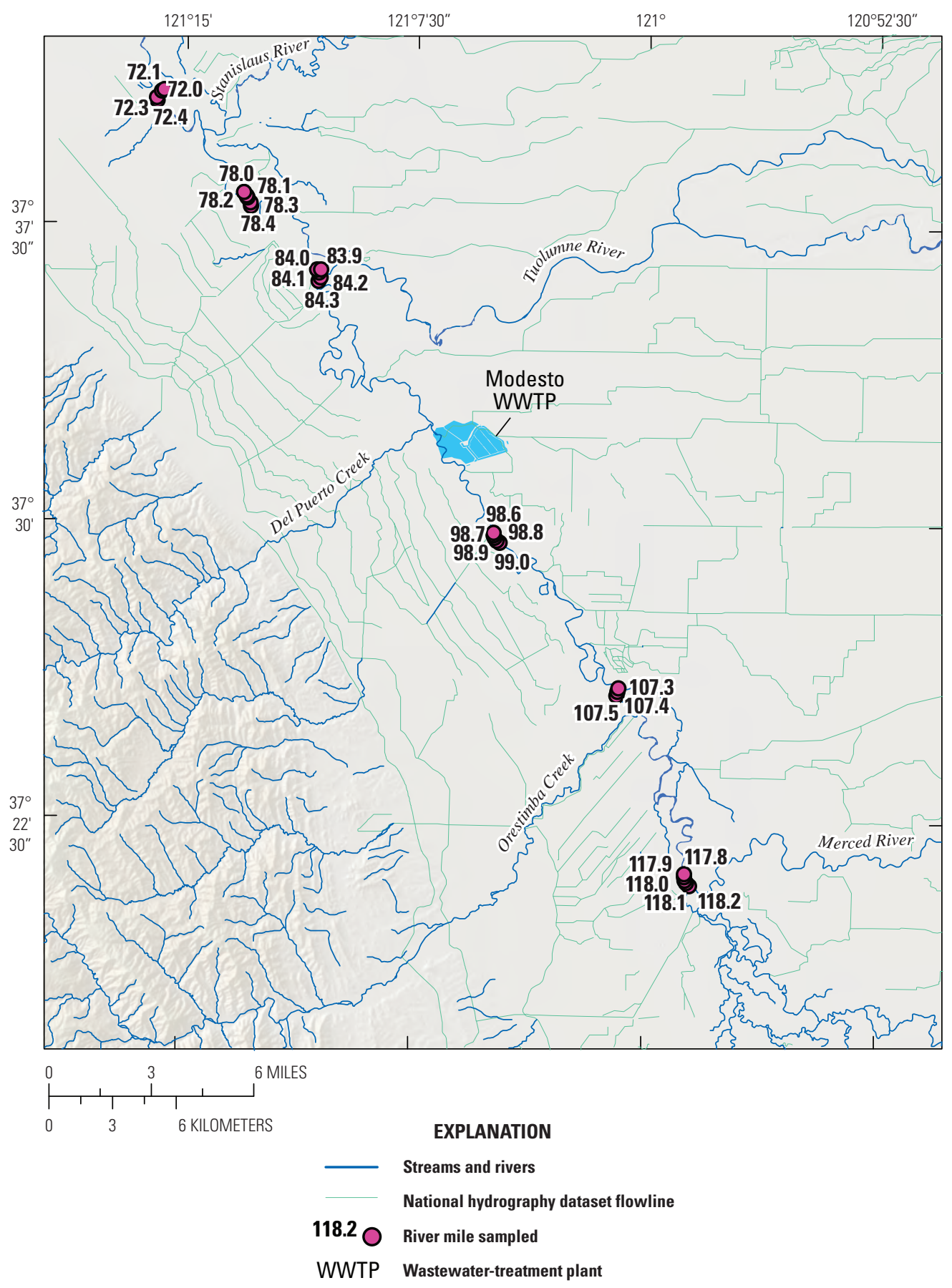

Figure 22. Sites sampled (river miles) during Synoptic III, September 2008. 
Synoptic IV—June 2009

In the final synoptic sampling (June 15-19, 2009), 56 transects, of which 52 were new, were made in 3 areas of elevated SC discovered in the previous synoptics (fig. 23). The three areas were between Salt Slough and Mud Slough (river miles 128.5 to 122.2 ; fig. $23 \mathrm{C}$ ), upstream of the Tuolumne River (river miles 86.0 to 84.0 ; fig. 23B), and between the Tuolumne and Stanislaus Rivers (river miles 80.9 to 78.2 ; fig. 23A). The goal of this synoptic was to better define the longitudinal extent of the elevated SC in the bed sediments of the upstream portion of the river between Salt Slough and Mud Slough. The latter two areas were sampled in detail because of the uncertainty about the source of the elevated SC. Measurements were made at 20 percent (east bank), 50 percent (midpoint), and 80 percent (west bank) of the total transect distance at two depths ( 1 and $3 \mathrm{ft}$ ). There were 330 measurements (55 transects, 2 depths, and 3 locations across a transect).

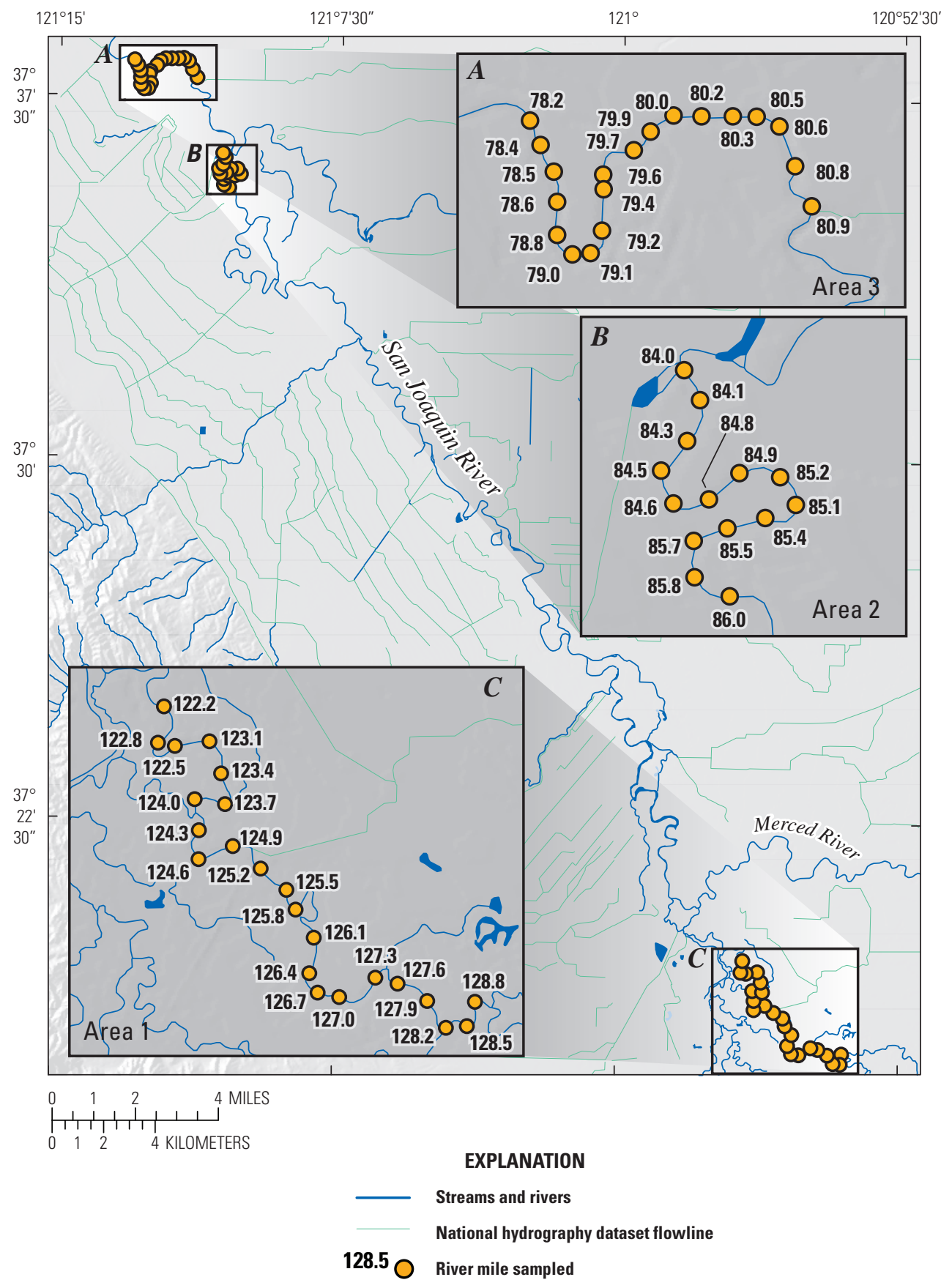

Figure 23. Sites sampled (river miles) during Synoptic IV, June 2009. $A$, refers to area $3 ; B$, refers to area 2; $C$, refers to area 1, as referenced later in discussion of streambed Synoptic IV results and figures $41-43$. 


\section{Longitudinal Profile Survey Sample Collection}

Samples were collected from the longitudinal profile survey either as discrete samples or as continuous longitudinal profiles. Discrete samples usually were collected by using equal-width-increment (EWI) techniques (Edwards and Glysson, 1999); however, safety considerations necessitated grab sampling at many locations. EWI samples were collected in Teflon bottles, using a USGS D95 depth-integrated sampler, and grab samples were filled directly into 3 -L Teflon bottles. Samples were kept on ice and processed in the field within 4 hours of sampling. Samples collected for optical analyses (absorbance and fluorescence) and DOC were filtered through pre-combusted glass-fiber filters by using 47-millimeter (mm) diameter, $0.2-\mu \mathrm{m}$ nominal pore size glass-fiber filters that had been baked at 500 degrees Celsius $\left({ }^{\circ} \mathrm{C}\right)$ to remove residual organic materials, using an aluminum filter holder. Samples for DOC concentration were acidified to $\mathrm{pH} 2$ by using reagent-grade concentrated $\mathrm{HCl}$ immediately after filtration.

Discrete samples for DOC, ultraviolet absorbance (UVA), and excitation-emission matrix spectroscopy (EEMS) were shipped on ice within 24 hours to the organic chemistry laboratory at the USGS California Water Science Center in Sacramento, California, and subsequently refrigerated at $4^{\circ} \mathrm{C}$. Samples for DOC, UVA, and fluorescence were analyzed within 5 days of collection.

Continuous measurements for colored dissolved organic matter (CDOM), estimated chlorophyll- $\alpha$ concentration, nitrate, and other water-quality parameters (temperature, $\mathrm{pH}$, SC, dissolved oxygen, and turbidity) were made during the longitudinal profile surveys by using a small powered watercraft modified to tow an instrumentation housing mechanically fastened to the starboard side of the boat. An instrument was designed to house the sensors, sample tubing, pump, and electrical cables. Instrumentation was powered using a 12-volt direct current, 100 amp-hour battery located in the boat, and were data recorded by using a custom data logger with a laptop to display data in real time (fig. 24).

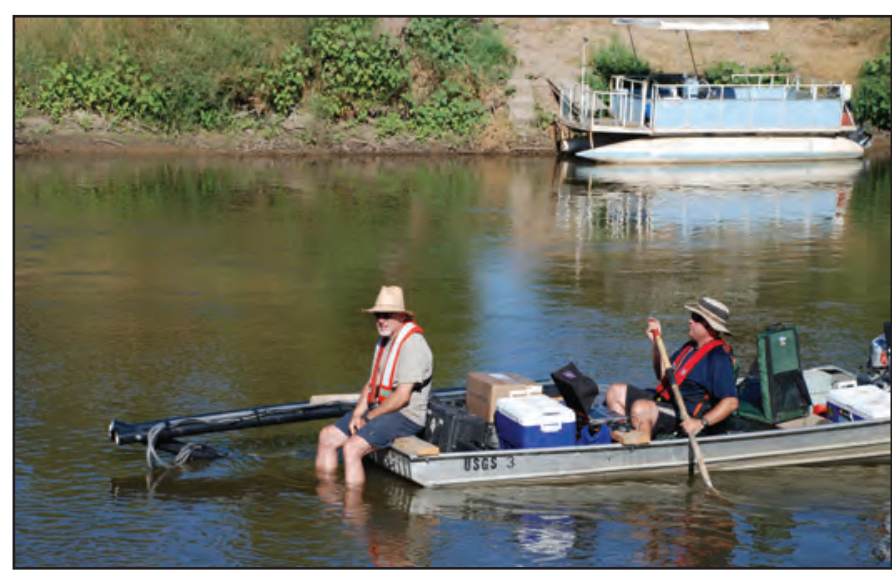

Figure 24. Watercraft used to tow and house instrumentation used for the collection of continuous longitudinal water-quality data. Photograph by Peter Dileanis, U.S. Geological Survey.
Spatial coordinates were logged using a Garmin model60CSx handheld GPS unit (Garmin International Inc., Olathe, Kansas). Time from the GPS was used to synchronize the time base of the laptop, data logger, and YSI sonde. Sample water was pumped through each sensor in the system by using Tygon tubing and an Amazon submersible 12Vdc pump (ITT Corporation, White Plains, N.Y.).

Water-quality parameters (temperature, $\mathrm{pH}$, conductivity, dissolved oxygen, turbidity) were measured in the stream by using a YSI model 6920 sonde (YSI Inc., Yellow Springs, Ohio) and logged at 1-second intervals. Dissolved organic matter (DOM) was measured by using an optical sensor designed to measure the fluorescent fraction of $\mathrm{CDOM}$, also known as fluorescent dissolved organic matter (FDOM; excitation at 370 nanometer and emission at 460 nanometer) by using a WETStar fluorometer (WET Labs, Philomath, Oregon). CDOM was used to estimate the quantity of fluorescent, humic-like DOM similar to Peak C that Coble (1996) found in EEMS spectra. The sensor flowpath was cleaned by using lens papers, 0.5-percent solution of Liquinox, and organic-free water, plus a final rinse of organic-free water as described in the user guide provided by WET Labs. Blankwater offsets were collected before every field deployment and subtracted from the field measurements (Downing and others, 2009). The CDOM data were converted from signal voltage to units of parts per billion (ppb) QSE (fluorescence of $1 \mathrm{ppb}$ quinine sulfate dihydrate in $0.1 \mathrm{~N} \mathrm{H}_{2} \mathrm{SO}_{4}$ ) by multiplying the blank-corrected output sample voltage of the WETStar fluorometer by an instrument-specific conversion factor supplied by the manufacturer.

Estimated chlorophyll- $\alpha$ concentration was measured using an in situ fluorometer designed to measure fluorescence of the primary photosynthetic pigment present in algae, which is useful as a proxy for phytoplankton biomass (WETLabs WETStar excitation at 470 nanometer and emission at 650 nanometer). The fluorescent response from the WETStar chlorophyll- $\alpha$ fluorometer was converted to into estimated chlorophyll- $\alpha$ concentration (micrograms per liter, or $\mu \mathrm{g} / \mathrm{L}$ ) using the manufacturer-supplied scale factor, characterized using a mono-species laboratory culture of Thalassiosira weissflogii phytoplankton. Pre-deployment cleaning and blank offsets were collected as described above.

Nitrate was measured continuously in situ using an ISUS model-V3 nitrate analyzer that had a detection range of 0.007 to 28 milligrams per liter $(\mathrm{mg} / \mathrm{L})$ and accuracy of plus or minus $0.028 \mathrm{mg} / \mathrm{L}$ (Satlantic, Inc., Halifax, Nova Scotia, Canada). The nitrate analyzer is an ultraviolet (UV) spectrophotometer, which calculates nitrate concentration from absorption measurements in the spectrum from 217 to 240 nanometer (nm). The ISUS was fitted with a flow cell and pumped using the submersible pump and a 25 -cm diameter, $0.2-\mu \mathrm{m}$ pore-size membrane filter (Osmonics Memtrex, Osmonics, Inc., Minnetonka, Minn.). The ISUS nitrate analyzer was cleaned prior to field deployment using Liquinox or laboratory-grade ethanol and blank-corrected using deionized, organic-free water. 


\section{Laboratory Analytical Methods}

The laboratory analyses of nutrients and DOC were done by two laboratories. Specific details of the laboratory analytical methods are presented by laboratory in appendix 1-1 and appendix 1-2. The nutrients and DOC samples were analyzed in the Dahlgren laboratory in the Department of Land, Air, and Water Resources (LAWR) at the University of California at Davis (UC Davis) using standard waterquality methods (Clesceri and others, 1998). The LAWR laboratory analyzed nutrients for the entire study period and DOC samples from July 2008 to January 2009. The DOC samples were analyzed by ultraviolet-enhanced persulfate digestion and infrared detection (Phoenix 8000; Teledyne Tekmar, Mason, Ohio) using Standard Method 5310C-with a method detection limit (MDL) of $0.1 \mathrm{mg} / \mathrm{L}$. Prior to the use of the LAWR laboratory (from September 2006 to June 2008), the USGS Sacramento Organic Carbon Laboratory analyzed DOC samples using a Shimadzu TOC-5000A Total Organic Carbon Analyzer by high temperature catalytic oxidation (U.S. Geological Survey method number O-2201-4; Bird and others, 2003) with a method detection limit of $0.3 \mathrm{mg} / \mathrm{L}$.

\section{Laboratory and Field Quality-Control Results}

Data obtained from quality-control (QC) samples were used to estimate the potential variability and bias from sample collection, processing, and laboratory analysis. Variability is defined as random error in independent measurements that can result with repeated application of the process under specified conditions. Bias refers to a systematic error manifested as a consistent positive or negative deviation from the known or true value. The results of the laboratory and field qualitycontrol samples are presented separately.

\section{Laboratory Quality-Control Results}

Analyses for the constituents presented in this report were done by two separate laboratories and are presented separately.

\section{OC Results from UC Davis LAWR Laboratory}

Variability in laboratory analysis was determined by replicate analyses of randomly selected environmental samples collected from the monitoring wells (bank wells and in-stream wells). Laboratory replicates were analyzed for nitrate (375 pairs), ammonium (439 pairs), and DOC (239 pairs). The variability is expressed in relative percentage difference (RPD) between the replicate analyses of the same environmental sample as follows:

$$
R P D=\frac{\left|C_{1}-C_{2}\right|}{\left(C_{1}+C_{2}\right) / 2} \times 100 \text { percent }
$$

where

$$
\begin{aligned}
& C_{1} \text { is the concentration in the first sample, and } \\
& C_{2} \text { is the concentration in the second sample of } \\
& \text { the replicate pair. }
\end{aligned}
$$

Bias in laboratory analysis was determined by evaluating analyte recovery in laboratory spikes. Laboratory spikes of nitrate, ammonium, and DOC were added and analyzed for 299 samples to examine bias as percentage recovery of a given constituent. Percent recovery, R( percent), for each spiked sample was calculated as follows:

$$
R(\%)=\frac{C_{S}-C_{U}}{C_{E}} \times 100 \text { percent }
$$

where

$$
\begin{aligned}
& C_{S} \text { is the concentration measured in the spiked } \\
& \text { sample, } \\
& C_{U} \quad \text { is the concentration measured in the unspiked } \\
& \text { sample, and } \\
& C_{E} \quad \text { is the expected concentration in the spiked } \\
& \text { sample. }
\end{aligned}
$$

The numbers of environmental samples and laboratory replicates and spikes analyzed for a given constituent are summarized in table 5 . The results in terms of variability and accuracy are presented in appendix 2-1 and appendix 2-2. The results of the laboratory QC tests done by the UC Davis LAWR laboratory were within the QC criteria for the project and met the data-quality objectives (appendix 3).

Table 5. Summary of the total number of environmental samples, laboratory replicates, and laboratory spikes analyzed for nitrate, ammonium, and dissolved organic carbon.

\begin{tabular}{lccc}
\hline & Nitrate & Ammonium & $\begin{array}{c}\text { Dissolved } \\
\text { organic carbon }\end{array}$ \\
\hline Environmental samples & 512 & 512 & 512 \\
Laboratory replicates & 375 & 439 & 239 \\
Laboratory spikes & 127 & 141 & 31 \\
\hline
\end{tabular}




\section{OC Results from USGS Sacramento Organic Carbon Laboratory}

Variability in laboratory analysis was determined by analysis of environmental replicate samples (sequential samples collected in the field). Samples were analyzed on an approximately weekly schedule for the period of the study. The variability between the field replicates was expressed as the average relative percentage difference (RPD) between analyses and was calculated as presented in equation 1. Laboratory bias for DOC was examined as percentage recovery of the standard reference material potassium hydrogen phthalate calculated as shown in equation 2, analyzed on an approximately weekly schedule, and expressed as the average percentage recovery for a given week. The laboratory QC performed by the USGS Sacramento Organic Carbon Laboratory was within the QC criteria for the project and met the data-quality objectives. The results are presented in appendix 3.

\section{Field Quality-Control Results}

The four types of field quality-control samples routinely collected during this study were field replicates, field blanks, trip blanks, and equipment blanks. All discrete water-quality samples (environmental and field quality-control) were collected by a team from UC Davis. The methods used to process the field quality-control samples are described in the USGS National Field Manual for Collection of Water-Quality Data (U.S. Geological Survey, 2006).

Replicate samples were used to identify and quantify the variability in results that could be attributable to the sample collection and laboratory analytical methods. The replicate samples were collected as split replicates; that is, a collected environmental sample was split into two samples, (one sample was considered an environmental sample and the other was considered the replicate sample) at various sites to characterize the reproducibility of the complete sample processing and analytical process.

All field blanks, trip blanks, and equipment blanks collected for the study were assembled using American Standard Testing and Materials (ASTM) type- 1 water. Field blanks were used to evaluate potential bias resulting from contamination of environmental samples by the analytes of interest during sample collection, processing, shipping, or analysis. No detections of analytes were found in the 23 field blanks collected and analyzed, the bank well sampling, or in the 7 field blanks collected and analyzed as part of the streambed synoptic surveys. Trip blanks were collected and processed with every sampling trip to the monitoring wells to mimic the typical field activities that an environmental sample would experience. A sample bottle was filled with ASTM type 1 water at the UC Davis LAWR Laboratory prior to departure for each sampling event, traveled in the vehicles, and was placed in the cooler with the environmental samples. The trip blank was analyzed with the same set of environmental samples collected on that day. No detections of analytes were found in the 20 trip blanks collected and analyzed as part of the bank well sampling or in the 8 trip blanks collected and analyzed as part of the streambed synoptic surveys.

Equipment blanks were run on the sample collection and processing equipment in the field prior to sampling to confirm the suitability of equipment to provide samples within the data-quality objectives of the project. No detections of analytes were found in the two equipment blanks run on the sampling equipment used for the bank well sampling or in the six equipment blanks run on the sampling equipment used for the collection of water-quality samples during the streambed synoptic surveys . Equipment blanks, replicate samples, and field QC for the YSI and other sondes were collected and analyzed for the longitudinal profile survey portion of this project, but the data are not provided in this report; these data are on file in the USGS California Water Science Center and can be provided upon request. All field QC results were within the project's QC criteria and met the data-quality objectives.

\section{Groundwater Interactions with the San Joaquin River}

The interaction of groundwater with the SJR was evaluated in four ways, as explained in this section-by differences in surface-water flows, by MODFLOW, by VS2DH, and by the hydraulic gradient and SC data collected during streambed synoptic surveys.

\section{Groundwater Flux by Differences in Surface- Water Flows and Diversions}

In many instances, groundwater flux (river gain or river loss) is estimated by the difference in surface-water flows between gaging stations (see figs. 5 and 6). In the lower SJR, this approach is complicated by the uncertainty of accuracy in the reported inflows and outflows values. In this section, we evaluate the feasibility of this approach for a longer period (August 2006-December 2007) and for a shorter period (August 15-September 7, 2007). 


\section{August 2006-December 2007}

The period of August 2006-December 2007 (17 months) was chosen because it covers the beginning of initial sampling of the monitoring wells (September 2006) and it is especially data rich for surface-water flows in the SJR and tributaries, with the operation of 13 short-term gages on discharges and diversions in the study reach by University of the Pacific (UOP; Stringfellow and others, 2008), in addition to the 7 long-term gages operated by USGS and DWR. The total of 20 gaged sites in the analysis include the upstream SJR flows at Stevinson (DWR), Salt and Mud Sloughs (USGS), Merced River (DWR), four west-side creeks and drains (three UOP and one USGS), seven east-side drains (UOP), Tuolumne River (USGS), Stanislaus River (USGS), and the three largest diversions (UOP; fig. 25). To analyze the potential groundwater flux by difference, the surface flows and diversions from the 20 gages were converted to "Vernalis time" using estimated travel times to Vernalis based on Kratzer and Biagtan (1997). In total, these 20 gaged surface flows and diversions accounted for 63 to 114 percent of the mean daily flows at Vernalis during the August 2006 to December 2007 period (fig. 25). The period of the first synoptic study is shown in the box in figure 25 (August 15-September 7, 2007).

The groundwater flux for this period, $3.64 \mathrm{cfs} / \mathrm{mi}$, was calculated as the average difference between the surface flows at Vernalis and the sum of the all of the inflows and diversions upstream of Vernalis. This flux compares to the average value of $1.4 \mathrm{cfs} / \mathrm{mi}$ from the 1988-89 study (Phillips and others, 1991) and to $1.5 \mathrm{cfs} / \mathrm{mi}$ from a calibrated regional-scale waterbudget model (Kratzer and others, 1987; Grober and others, 1992) that simulated an average groundwater discharge by river mile for a 60-mi reach of the SJR for water year 1985, which was classified as a dry year.

Although the period of August 2006-December 2007 was especially data rich, there were, nevertheless, several assumptions that had to be made. Flow data for the second largest diversion, Patterson Irrigation District, had to be estimated for all of 2007. This estimation was done using previous years of Patterson Irrigation District diversion data and the ratio of West Stanislaus Irrigation District to Patterson Irrigation District diversions from 2006. Five of the east-side drains had periods of missing record, which were interpolated

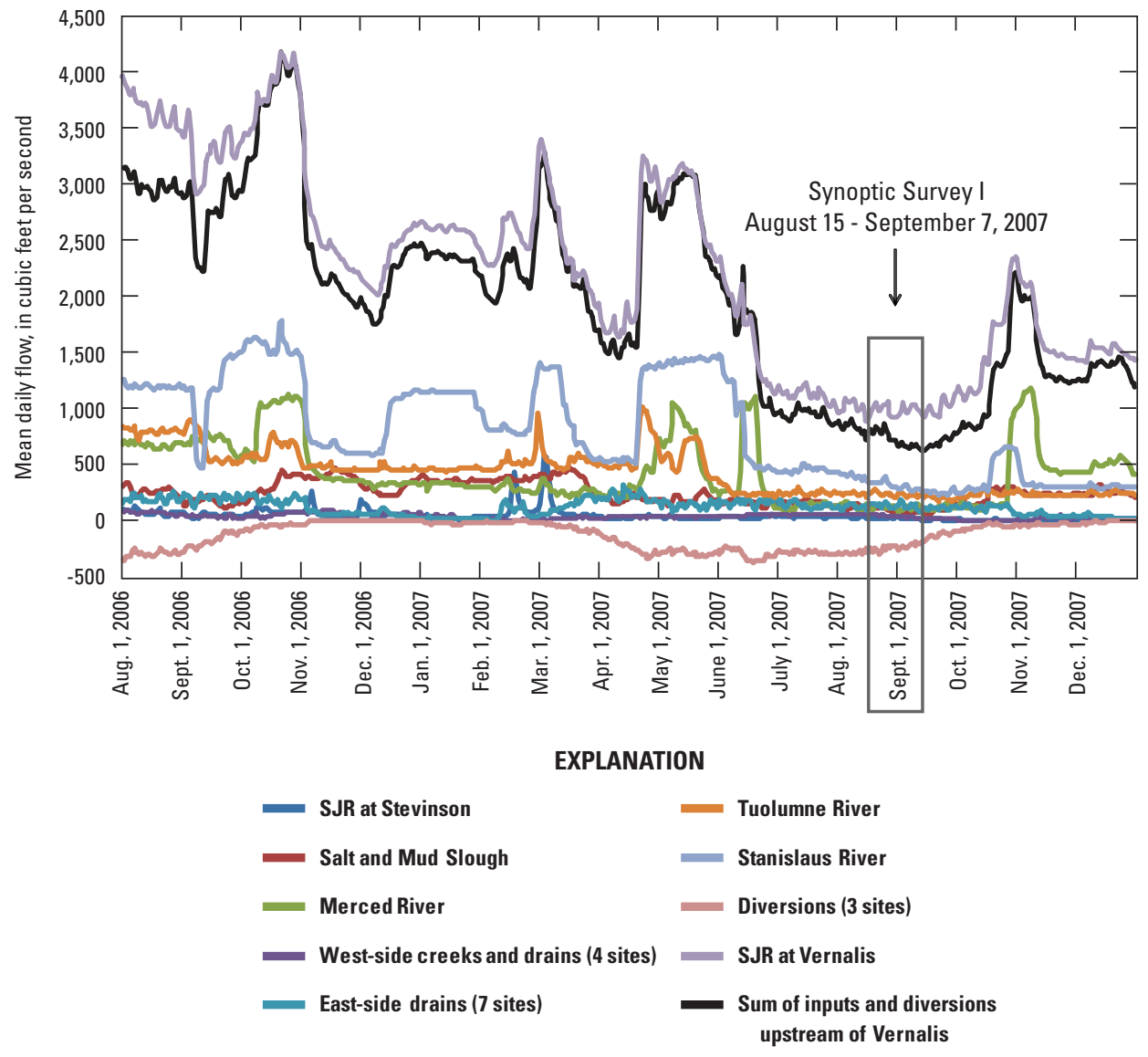

Figure 25. Mean daily flow of surface-water inputs and diversions for the San Joaquin River (SJR) upstream of Vernalis (August 1, 2006-December 31, 2007) in Vernalis time. 
(by straight line) from the available record. Data for the third largest diversion (El Solyo Water District) were only reported monthly and were converted to daily values by simulating the seasonal pattern of the West Stanislaus Irrigation District diversions while matching the mean monthly values. In addition to the assumptions required for the sites with gages, there were many other ungaged inflows and outflows in this reach of the lower SJR (see figs. 5 and 6). These inflows and outflows were not included in the flow analysis calculations because flow data were unavailable.

\section{August 15-September 7, 2007}

The same process that was used for the longer period also was used to evaluate the surface flows at Vernalis for August 15-September 7, 2007 (24 days). This shorter period was selected because it was a subset within the first synoptic survey. The same 20 gaged surface flows and diversions were used and converted to Vernalis time, and hourly flows were used instead of mean daily flows. The sum of the inflows and outflows accounted for 60 to 90 percent of the hourly flows at Vernalis (fig. 26). As with the longer period, several assumptions were required. The three diversions did not have hourly data, and, thus, the daily diversion rate from the actual or estimated daily record was used for each hour. Hourly flows for three east-side drains had to be estimated from daily flows based on the hourly patterns of the other four east-side drains. The daily flow record for one west-side creek (Del Puerto) was missing for this period, and an hourly record was simulated on the basis of 70 percent of the hourly flows in nearby Orestimba Creek, which was calculated as the ratio of the irrigation season basin size of Del Puerto Creek $\left(8.2 \mathrm{mi}^{2}\right)$ to Orestimba Creek $\left(10.8 \mathrm{mi}^{2}\right)$. In addition to the assumptions required for the sites with gages, there were many other ungaged inflows and outflows in this reach of the lower SJR (see figs. 5 and 6). These inflows and outflows were not included in the flow- analysis calculations because flow data were unavailable.

The groundwater flux for August 15-September 7, 2007, was calculated as $4.36 \mathrm{cfs} / \mathrm{mi}$. Thus, the groundwater flux for the shorter period was about 20 percent greater than for the longer period.

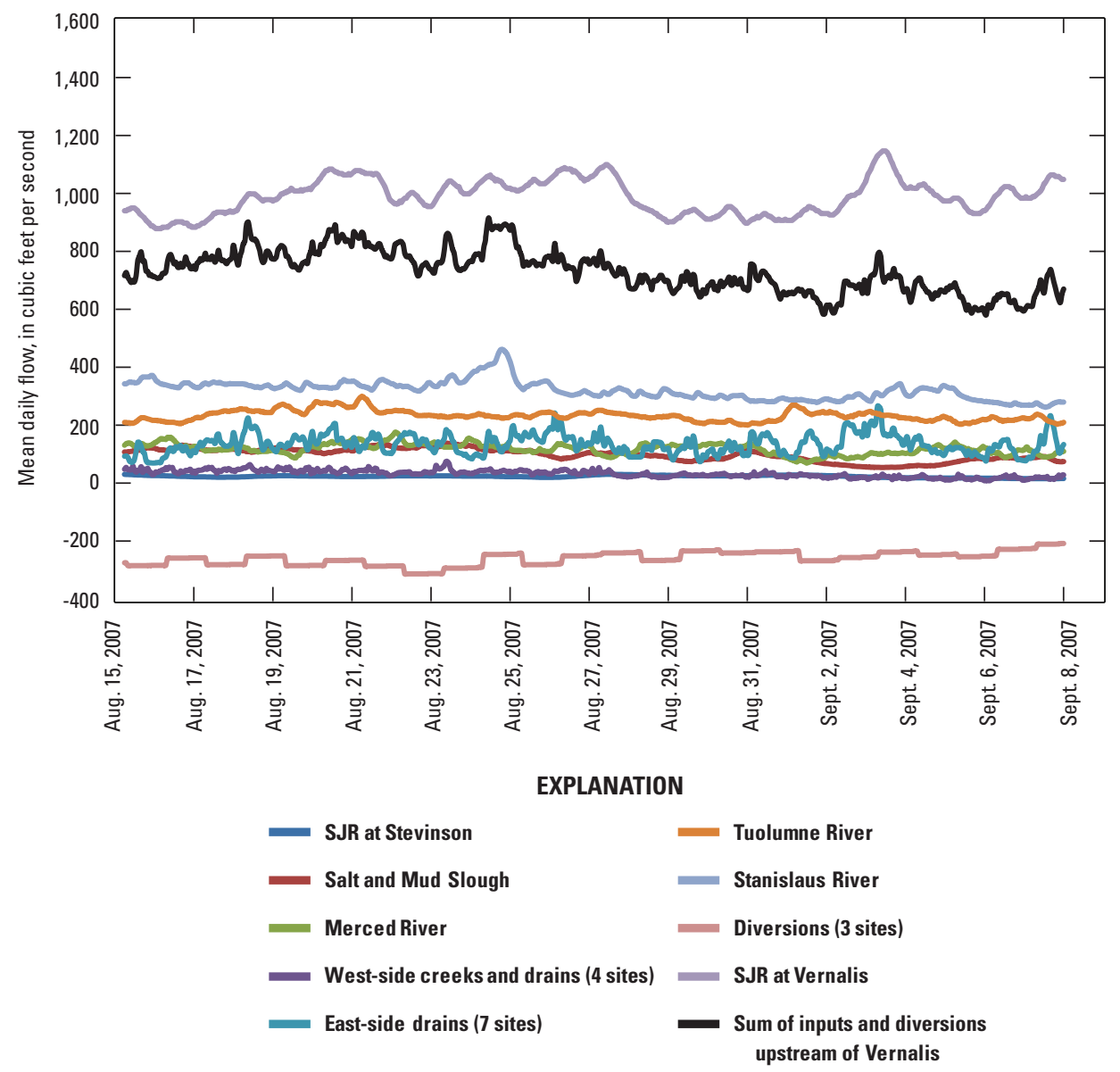

Figure 26. Mean daily flow of surface-water inputs and diversions for the San Joaquin River (SJR) upstream of Vernalis (August 15-September 7, 2007) in Vernalis time. 


\section{MODFLOW Model Implementation}

Two-dimensional steady-state groundwater flow models were created to estimate groundwater discharge to the SJR at each of the bank well sites (Newman, Crows Landing, and Patterson). These models were recreated using the same dimensions, textural information, and hydraulic properties as models created with MODFLOW for these same sites in a 1988-89 study done by Phillips and others (1991). The intention of using the same modeling approach was to compare the estimated groundwater discharge rates for past (Phillips and others, 1991) and present (2006-08) studies. The flow models represent vertical cross sections oriented perpendicular to the river near each of the bank well sites. Water-level data from each of the bank wells were used to calculate a yearly median water level (from May 2007 through July 2008) for each well. Median stream stage was also calculated from the USGS gaging stations located at each of the bank well sites for the same period. For modeling purposes, the elevation of the median stream stage was subtracted from the elevation of each of the median water levels in the bank wells, thus changing the baseline from mean sea level to median stream stage. The differences between the median water levels in the bank wells and the median stream stage at each of the sites were used to calibrate the model.

\section{Model Framework}

The size and discretization of the model grid are identical for each of the three sites. The model cross section is $3,560 \mathrm{ft}(0.67 \mathrm{mi})$ wide by $180 \mathrm{ft}$ deep (fig. 27). The SJR is at the midpoint of the grid and is approximated by a block of cells $160 \mathrm{ft}$ wide and $6 \mathrm{ft}$ deep. These dimensions are based on measurements of river width and measured depth profiles. The model grid is divided horizontally into a total of 32 columns, 16 on each side of the river midpoint. Horizontal cell dimensions are a minimum of $20 \mathrm{ft}$ wide, periodically increasing in width with distance from the river. The grid is divided vertically into 20 layers of variable thickness. Layers 1-5, 6-8, 9-17, and 18-20 are 3, 5, 10, and $20 \mathrm{ft}$ thick, respectively.

The types of boundary conditions for the model at each site included a constant-head boundary, no-flow boundaries, and specified-flux boundaries (fig. 27). The constant-head boundary size and location were identical at three model sites and represented the SJR. The value assigned to the constant-head boundary was the median stream stage for each respective site. A no-flow boundary at the bottom of the modeling domain was delineated by the contact of the Sierran sand and the Corcoran clay member. No-flow boundaries were also assigned to the vertical sides of the cross sections perpendicular to the river and were delineated on the basis of the assumption that flow is parallel to the cross section. The water-table map (fig. 19) shows that this is a reasonable assumption, although small-scale alternative flow patterns could exist near the river.

The east and west model faces are specified-flux boundaries, which are used for simulating the effects of groundwater recharge and discharge (pumpage) outside the model domain. Groundwater recharge was applied to the east face of the models at each site. Unique specified-flux scenarios that best represented the horizontal flow directions based on median water levels in the well cluster sites on the east and west banks were applied to the west face of each model. At the Newman site, discharge was applied to the west face. At the Crows Landing site, the specified flux on the west was

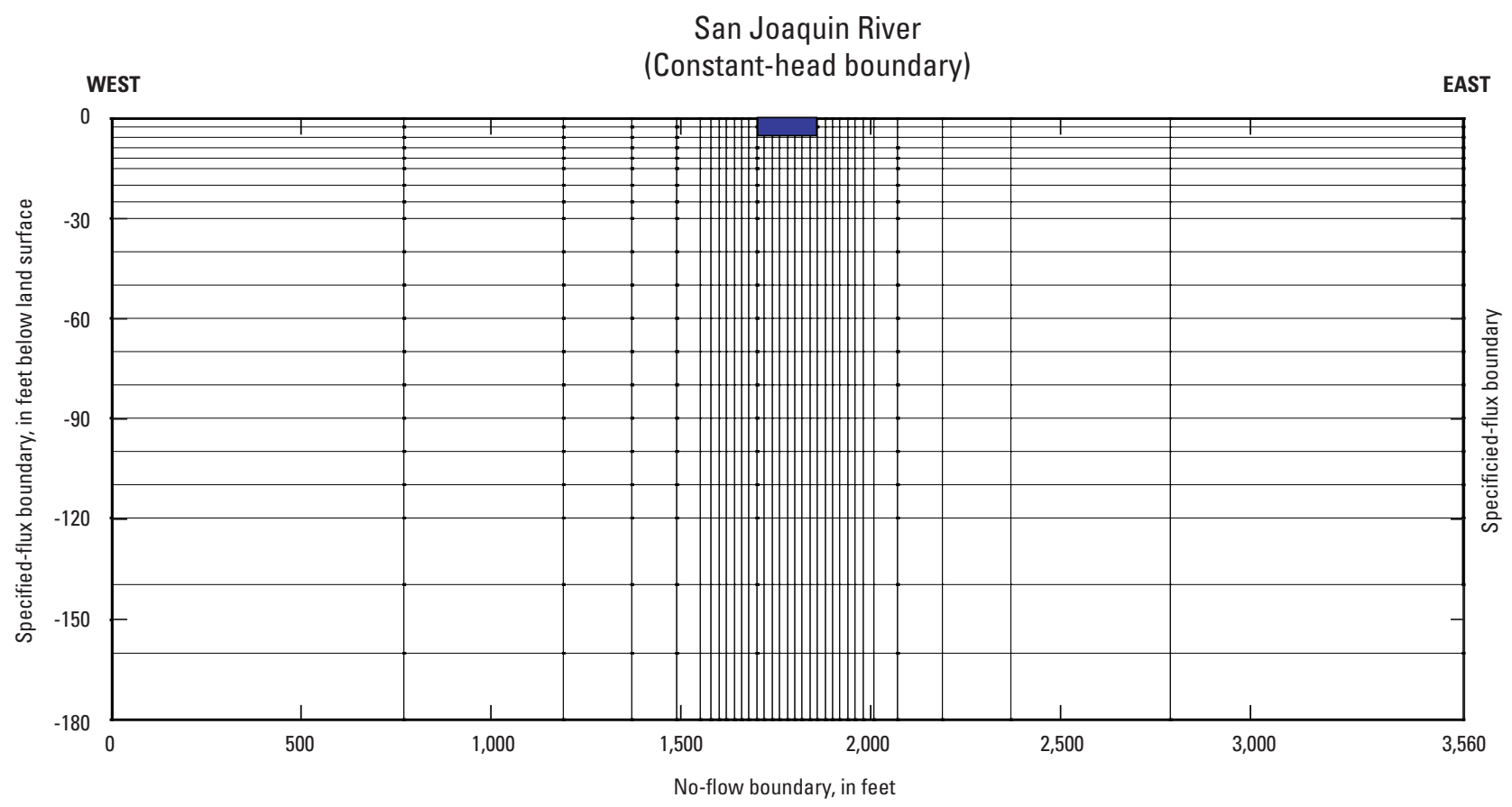

Figure 27. Dimensions and discretization of the MODFLOW model grid and specifications of boundary conditions. 
split between recharge and discharge. Recharge was applied to the top half of the model layers, and discharge applied to the bottom half. Because of the significant groundwater pumping near the well cluster on the west side of the Patterson site, the applied specified flux was split between two discharge rates, with the top half greater than the bottom discharge rate. The applied recharge and discharge were distributed in amounts proportional to the transmissivity of each model layer for the model at each site.

The conceptual models created were isotropic and homogeneous with the exception of a single 5-ft thick layer of relatively low hydraulic conductivity. This lowconductivity layer is continuous, within $30 \mathrm{ft}$ of the land surface and conceptually represents fine-grained flood-basin deposits. This conceptual model is not intended to be an accurate representation of the observed lithology at each cross section. Instead, it is intended to represent a range of plausible conditions based on the limited lithologic data collected, estimates of horizontal hydraulic conductivities for Sierran sand from analysis of slug and bail tests done by Phillips and others (1991), and estimates of vertical hydraulic conductivities determined by calibrations of three different conceptual models by Phillips and others (1991). Values of horizontal and vertical hydraulic conductivity for the conceptual model were taken from Phillips and others (1991).

\section{Calibration and Sensitivity Analysis}

Model calibration was done in two steps. The first step was a trial-and-error process that yielded calibrated versions of each conceptual model that were capable of producing a reasonable hydraulic head distribution. The second step was systematic alteration of values of calibrated model parameters to determine the uniqueness of the solutions and the sensitivity of the calibrated models to changes in these parameters.

\section{Calibration Criteria}

Water levels measured in monitoring wells and stream stages recorded at the study sites were used to calibrate the models at each site. The error between the measured water levels and simulated hydraulic heads served as a calibration criteria. Steady-state hydraulic heads were approximated by the median values of weekly water-level measurements from May 2007 through July 2008. For modeling purposes, the median stream stage was subtracted from each of the median water levels in bank wells, thus changing the baseline from mean sea level to median stream stage. The resulting values are presented on the schematic cross sections in figure 28 .

Because of the significant localized pumping near the west bank wells at the Patterson site, calibration to the measured water levels was not possible given the twodimensional conceptual model used for this study. No results are presented for the Patterson site. Furthermore, the waterlevel records for the in-stream well were generally incomplete because of data logger malfunctions during the period of study. Consequently, the Crows Landing deep in-stream well
(CRD) was the only in-stream monitoring well quantitatively used during model calibration.

Three of the bank wells shown in figure 28 were not used quantitatively during model calibration. Two shallow bank wells were likely affected by local sources of recharge not accounted for in the model: NW-14.5, on the west side of Newman site, and CW-18.2, on the west side of the Crows Landing site. The Newman site is next to an irrigated field bordered by a ditch. At the Crows Landing site, a small pond, about $20 \mathrm{ft}$ from the bank well, is used as an overflow disposal area and was partially full during most of the study period. The third well not used in the model calibration was NE-35.5, on the east side of the Newman site. This well did not fit the conceptual model because the difference between the median stream stage and water level in this bank well was greater than the difference in the adjacent shallow (NE-14.5) well.

\section{Calibration}

The first step in the model calibration was to vary the recharge, discharge (pumpage), or both on the eastern and western boundaries for each of the model domains until the solution best matched the measured water levels. The primary measure of model fit was the quantitative comparison of measured water levels and simulated hydraulic heads calculated by MODFLOW as part of the calibration process using the root mean-square error (RMSE). Qualitative measures of model fit also were used because two different sets of parameters would sometimes yield similar RMSEs, but different head distributions. The differences were often apparent when comparing the simulated water-table elevations at the east and west boundaries. For example, solutions were rejected if the water table on the eastern boundary was below the stream stage because this constitutes a large-scale depression in the water table, for which there is no supporting evidence.

In the second step of calibration, the uniqueness of the calibrated solutions for each of the cross section models was tested. Systematically, values of recharge and vertical hydraulic conductivity were varied (lower and higher) from the calibrated solutions. These parameters were varied by amounts large enough to ensure that the calibrated model was bounded by inferior solutions, but small enough to remain within a range of physically reasonable values. Recharge was altered by a factor of 2, and vertical hydraulic conductivity by a factor of 3 . For each given combination of recharge and vertical hydraulic conductivity, discharge at the western boundary was adjusted until the measured water level in the deep western well was matched. The resulting distribution of hydraulic head was compared with measured water levels, and the RMSE calculated. Figure 29 provides a summary of the results. The center of each three-by-three grid represents the calibrated model resulting from systematic changes in recharge, vertical hydraulic conductivity, or both and the associated change in pumping. The RMSE for each solution is shown in the upper left-hand corner of each square in the figure. 
$\boldsymbol{A}$

WEST

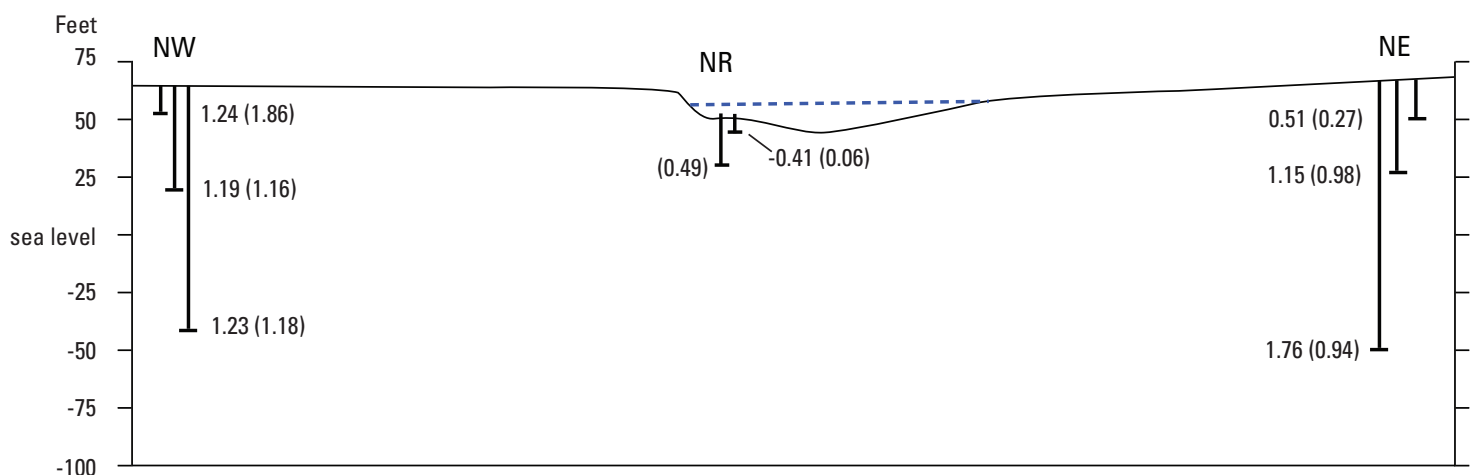

B

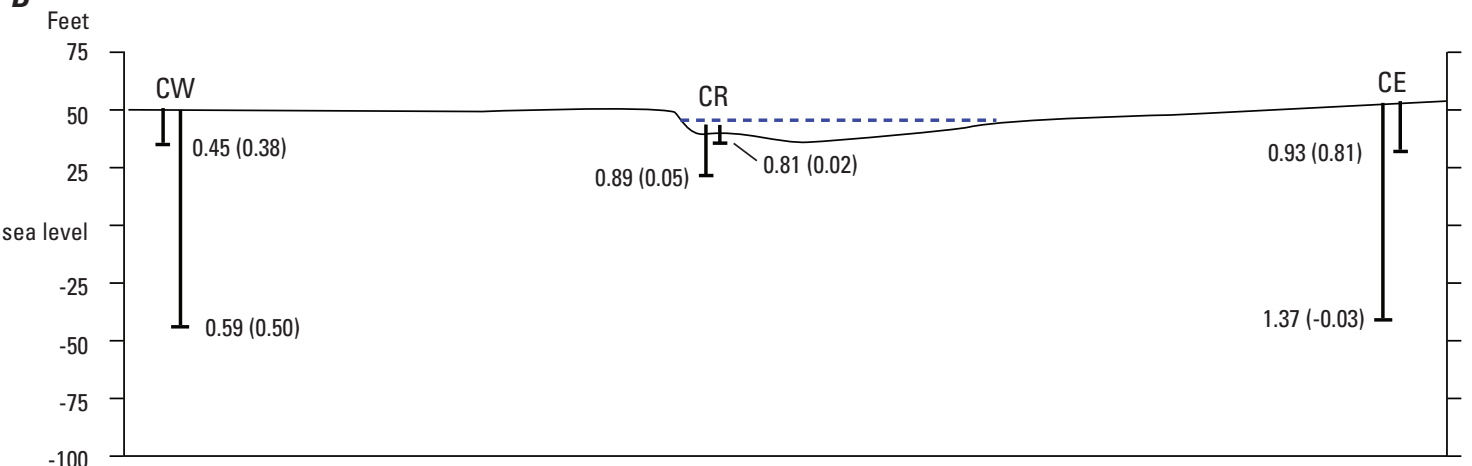

C

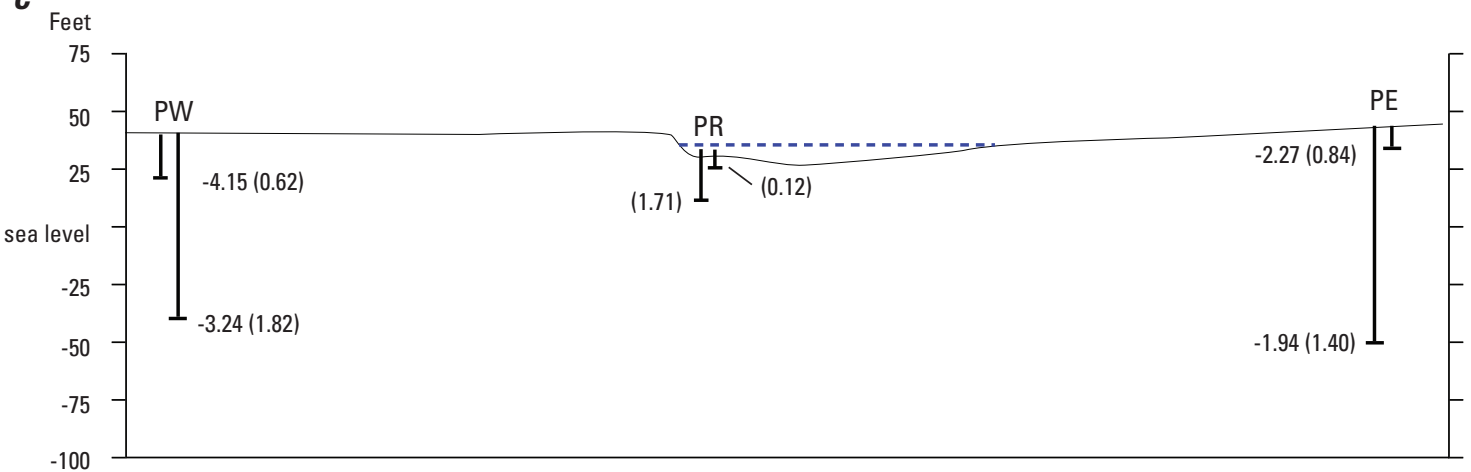

\section{EXPLANATION}

Land surface referenced to the North American Vertical Datum of 1988 (NAVD 88) approximately located between well cluster sites.

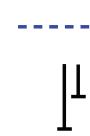

Median stream stage of the San Joaquin River approximately between bank wells.

Bank well site- site at which two or more monitoring wells are installed at different depths See table 4 for explanation of cluster site name and location.

$0.81(0.05$

Number(s) represent present and historical (in parenthesis) median water levels in feet. Midpoint of 5-foot screened interval of individual bank well or total depth of in-stream well above or below (-) median stream stage for the respective study periods.

Figure 28. Median water levels in bank wells relative to median stream stage for the 2007-08 and historic (1988-89) modeled periods: $A$, Newman site; $B$, Crows Landing site; and $C$, Patterson site. 
$\boldsymbol{A}$

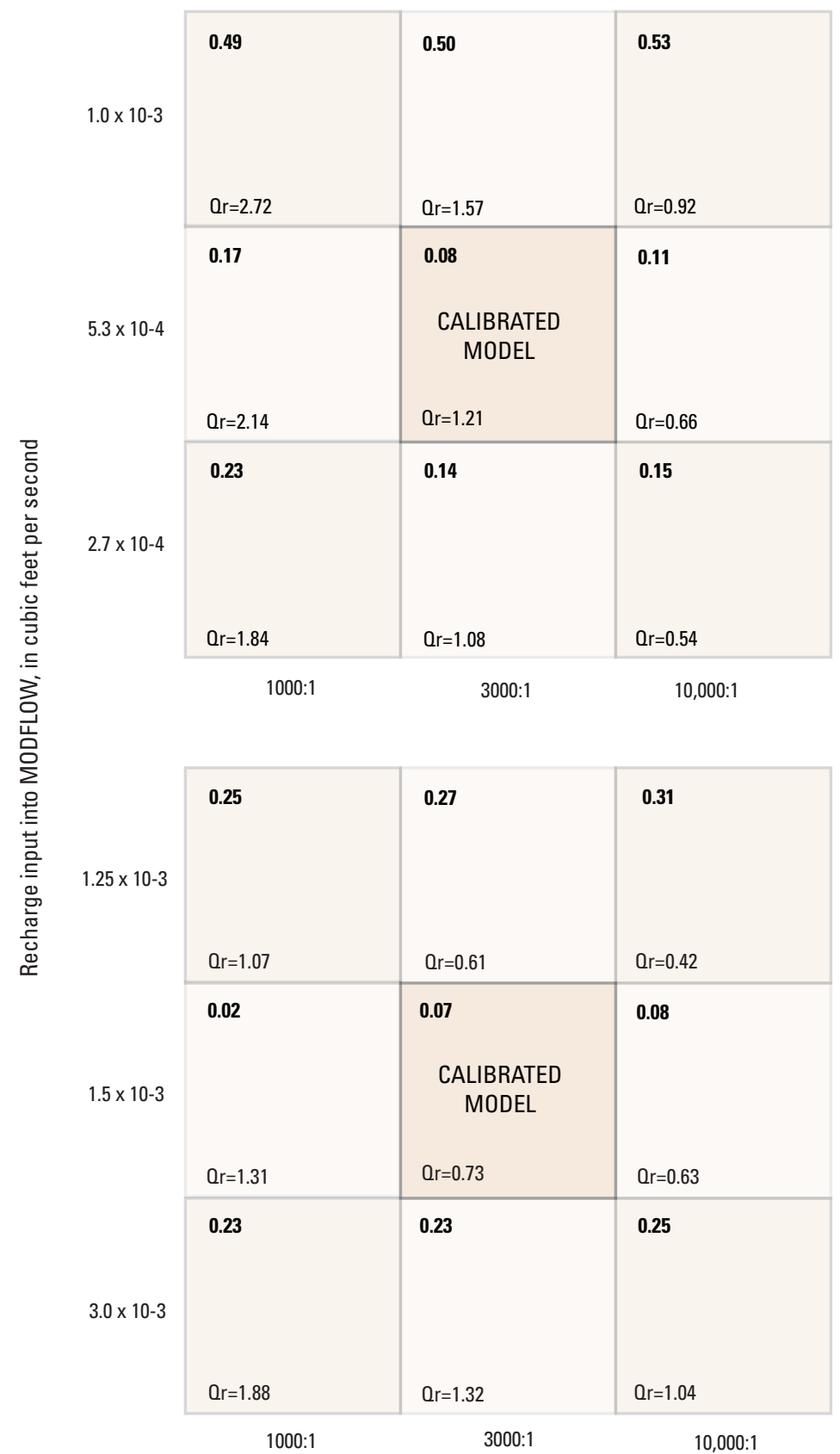

Ratio of horizontal hydraulic conductivity to vertical input into MODFLOW, dimensionless

\section{EXPLANATION}

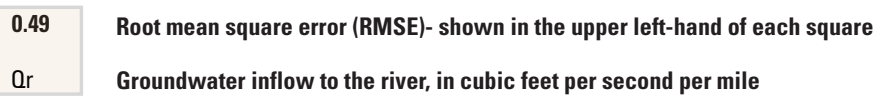

Figure 29. Summary of calibration results from MODFLOW for the $A$, Newman site; and $B$, Crows Landing site. Each square represents a modeled solution, with the center square representing the calibrated solution. 
The calibrated solutions were associated with relatively low values of RMSE. Some of the competing solutions had slightly lower RMSEs than that of the calibrated solution. Through qualitative assessment of hydraulic head distributions, all these competing solutions were determined to be inferior to the one selected as the calibrated solution. Most of these competing solutions were ruled out on the basis of the simulated values at the lateral boundaries, often because the water table at the eastern boundary was lower than the stream stage. Thus, through the use of quantitative and qualitative measures, each of the calibrated model solutions was determined to be superior to the competing solutions.

\section{Model Results}

The results of the calibrated models indicated that the predominant horizontal groundwater flow direction between the deep bank wells at the study sites was westward beneath the river. This flow direction could be the result of localized or west-side pumping. When comparing the past study (Phillips and others, 1991) to the present study, model results indicate that west-side pumping has become significant enough to create a horizontal flow reversal at the study sites. The model results indicate that the westward flow across the valley trough occurs at the Newman and Crows Landing sites and is a substantial component of flow. Although the model calibration for the Patterson site was not possible given the twodimensional conceptual model, water levels in the bank wells indicate that westward flow also occurs at this site. Simulated shallow horizontal flow at this site was toward the river, and simulated vertical flow beneath the river was upward.

Groundwater discharge rates to the SJR from this study (2007-08 rate), the Phillips and others (1991) study (1988-89 rate), and a regional-scale water-budget model (Kratzer and others, 1987; Grober and others, 1992) that produced average groundwater discharge rates for the SJR by river mile for a 60-mi reach (1985 rate) are compared in table 6. This study and the Phillips and others (1991) study were carried out under critical to below-normal water-availability conditions, whereas the 1985 study was done during a dry year (table 3, fig. 4). The average 2007-08 simulated groundwater discharge results for the Crows Landing and Newman calibrated models were both $1 \mathrm{cfs} / \mathrm{mi}$. This value compares to the average value of $1.4 \mathrm{cfs} / \mathrm{mi}$ from the 1988-89 study (Phillips and others, 1991) and to the average value of $1.5 \mathrm{cfs} / \mathrm{mi}$ from a calibrated regional-scale water-budget model (Kratzer and others, 1987; Grober and others, 1992).

The average rate of recharge (water applied to the model east and west facies) for the calibrated model at the Crows Landing and Newman sites was $1.02 \times 10^{-3} \mathrm{cfs} / \mathrm{ft}$, and the average rate of pumpage (simulated agricultural pumpage) was $8.26 \times 10^{-4} \mathrm{cfs} / \mathrm{ft}$. If these sites are considered to be representative of the 10-mi reach between sites, the average estimated rates for groundwater recharge and pumpage were 5.4 and $4.4 \mathrm{cfs} / \mathrm{mi}$, respectively. These values indicated that, on average, about 81 percent of groundwater entering the model cross sections is discharged through agricultural pumping, and the remaining 19 percent is discharged through the river. Simulated recharge and pumpage rates from the Phillips and others (1991) model for the same sites, were 7.1 and $4.7 \mathrm{cfs} / \mathrm{mi}$, respectively. In the Phillips and others study, 66 percent of groundwater entering the model cross section was determined to be discharged through agricultural pumping and the remaining 34 percent was discharged to the river. The difference in values between the two studies indicated a 15 percent increase in simulated agricultural pumpage and a 15 percent decrease in the rate of groundwater discharging to the SJR.

\section{Model Limitations}

The intention of the groundwater models developed for this project was to recreate models developed by Phillips and others (1991) in order to estimate groundwater discharge rates to the SJR under different hydrologic conditions. The two-dimensional steady-state groundwater models were created using the same textural information, dimensions, and hydraulic properties as in the original models, and boundary conditions were adjusted, within reason, to best match recent water-level measurements. Because groundwater flow systems are inherently complex, this modeling approach

Table 6. Simulated groundwater discharge rates to the San Joaquin River for the past and 2007-08 modeled periods.

[Discharge in cubic feet per second per mile; -, no results as calibration of model at this site was not possible]

\begin{tabular}{lccc}
\hline \multirow{2}{*}{$\begin{array}{c}\text { Well cluster } \\
\text { site name }\end{array}$} & \multicolumn{3}{c}{ Simulated groundwater discharge } \\
\cline { 2 - 4 } & $\mathbf{1} \mathbf{1 9 8 5}$ rate & ${ }^{\mathbf{2} \mathbf{1 9 8 8 - 8 9} \text { rate }}$ & $\mathbf{2 0 0 7 - 0 8}$ rate \\
\hline Newman & 1.7 & 1.8 & 1.2 \\
Crows Landing & 1.4 & 1.1 & 0.7 \\
Patterson & 1.4 & 3.2 & - \\
Average & ${ }^{3} 1.5$ & ${ }^{3} 1.4$ & ${ }^{4} 1.0$ \\
& ${ }^{5} 1.6$ & ${ }^{5} 2.0$ & \\
\hline
\end{tabular}

${ }^{1}$ From Kratzer and others, 1987.

${ }^{2}$ From Phillips and others, 1991.

${ }^{3}$ Value represents average rate of Newman and Crows Landing sites for comparison to 2007-08 rate.

${ }^{4}$ Value represents the simulated groundwater discharge rate used for estimating loads of dissolved inorganic nitrogen and dissolved organic carbon.

${ }^{5}$ Value represents average rate of all three sites. 
has several limitations: (1) the two-dimensional conceptual models cannot reasonably account for localized pumping, particularly from wells not within the cross section, and consequently, calibration to the measured water levels at the Patterson site was not possible; (2) the steady-state approach assumes a system is at equilibrium, and although the waterlevel hydrographs indicated this is generally the case at the Newman and Crows Landing sites, localized groundwater pumping at the Patterson site violates this assumption; and (3) the layered conceptual model (isotropic and homogeneous, with a low hydraulic conductivity layer) is simplistic and is not an accurate representation of the observed lithology at each cross section.

The assumption that the hydrogeology at the three cross sections is representative of conditions along the entire reach could cause errors in estimates of groundwater discharge to the reach. The reason for this is that the three cross sections are oriented parallel to the direction of regional groundwater flow, and a significant proportion of the river is orientated at an oblique angle to regional flow. The maximum over-estimation of groundwater discharge would be about 50 percent based on the difference between the actual length of the reach and the length of a smooth curve following the general course of the river. Results from these models are to be interpreted as general and are intended for comparative analysis rather than predictive purposes.

\section{VS2DH Model Implementation}

Using heat as a tracer in conjunction with water-level measurements has been shown to be an effective method for estimating rates of surface-water and groundwater exchanges (streambed flux; Silliman and Booth, 1993; Silliman and others, 1995; Stonestrom and Constantz, 2003; Anderson, 2005; Constantz, 2008). This method requires continuous monitoring of stream temperature and stream stage, the temperature at multiple depths below the streambed, and the hydraulic head at the depth of the deepest temperature measurements. Heat is transported primarily by conduction and advection with flowing water (Stonestrom and Constantz, 2003; Constantz, 2008). Consequently, observations of streambed temperature variation with depth can give qualitative indications of streambed flux. If there is no water flux through the streambed (a neutral stream), heat is transported conductively, and there is gradual progression in temperature in the bed from the groundwater temperature below the streambed to the stream-water temperature at the surface (fig. 30A). When there is upward flow of groundwater (a gaining stream), the intermediate depth temperatures are influenced more by groundwater temperature relative to a neutral stream (fig. 30B). Conversely, when there is downward flow (a losing stream), the intermediate depth temperatures are influenced more by stream temperature (fig. 30C).

One-dimensional modeling of heat and water flow was used to interpret the temperature and water-level observations and to estimate vertical streambed flux and streambed conductance at each of the in-stream monitoring well sites. For the purposes of this report, positive streambed flux values (gaining stream) are referred to as "river gain” and negative streambed flux values (losing stream) are referred to as "river loss.” The temperature and water-level observations were input into the USGS numerical model VS2DH. The streambed flux was modeled at each site, set up as a one-dimensional model, and only flow in the vertical direction was simulated in order to simplify the boundary conditions. This process is valid for determining surface water and groundwater interactions at the streambed interface, but not for determining lateral flow and bank storage (Stonestrom and Constantz, 2003; Constantz, 2008).

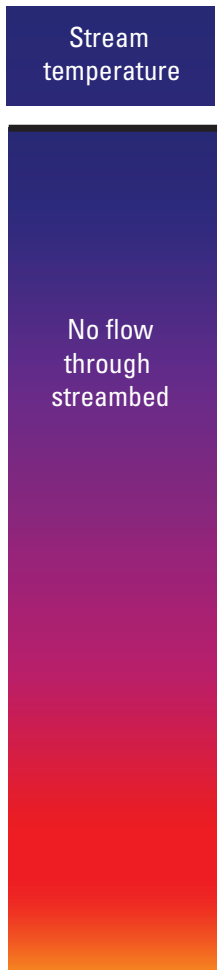

Groundwater temperature

A
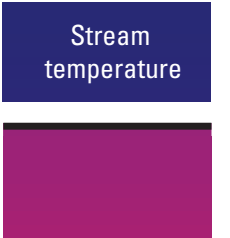

Streambed

temperature

is strongly

influenced

by ground-

water

temperature

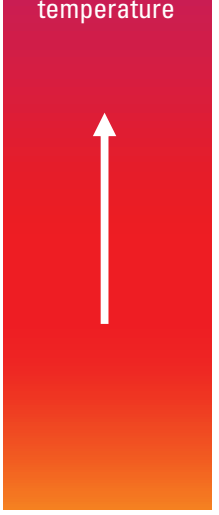

Groundwater

temperature

B

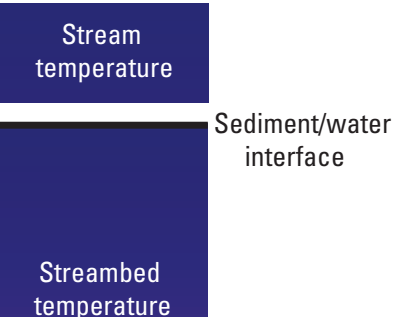

is strongly

influenced

by stream

temperature

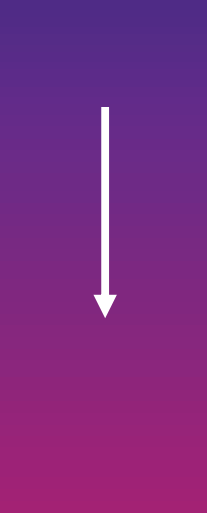

Groundwater

temperature

C
Figure 30. Streambed temperature profiles for $A$, a neutral stream; $B$, a gaining stream; and $C$, a losing stream reach. 


\section{Model Framework}

The model domain dimensions were $1 \mathrm{~m}$ wide $(3.2 \mathrm{ft}$ ) by approximately $2 \mathrm{~m}$ in depth $(6.5 \mathrm{ft})$. The length of each model varied slightly, as the depths that the shallow in-stream wells were installed below the sediment and water interface could not be accurately replicated at each site. The conceptual model for each site assumed homogenous streambed sediments throughout the model domain. The vertical discretization of the model grid $(0.01 \mathrm{~m})$ was identical for each of the six sites (fig. 31). The top boundary of each model was assigned the observed stream stages and temperatures over time. The bottom boundary of each model was assigned the deepest observed groundwater levels and temperatures over time. No-flow boundary conditions were assigned to the lateral boundaries, of the model domain and, therefore, is considered a one-dimensional model with flow in the vertical direction only. Observation points representing the depths at which temperature was continuously recorded below the streambed were assigned to the appropriate depths within the model domain.

\section{Calibration and Sensitivity Analysis}

Model calibration was done in two steps. The first step was a trial-and-error calibration approach that yielded simulated streambed temperatures that visually fit the observed streambed temperatures at depth. The streambed temperatures measured at $0.5,1.0,1.5$, and $3.0 \mathrm{ft}$ below the streambed were used to calibrate each of the models. The second step was a systematic alteration of calibrated model parameters to measure and compare the goodness-of-fit between model runs using the RMSE (adapted from Helsel and Hirsh, 1992). The RMSE was calculated for each observation point and modeling period (if applicable). The RMSE for each observation point was calculated as follows:

$$
R M S E=\sqrt{\frac{\sum_{i=1}^{n}\left(x_{i}-x_{p}\right)^{2}}{n}}
$$

where

$x_{i} \quad$ is the observed temperature at time step $\mathrm{i}$,

$x_{p}$ is the predicted temperature at time step $i$, and

$\mathrm{n}$ is the number to observations for each modeling period.

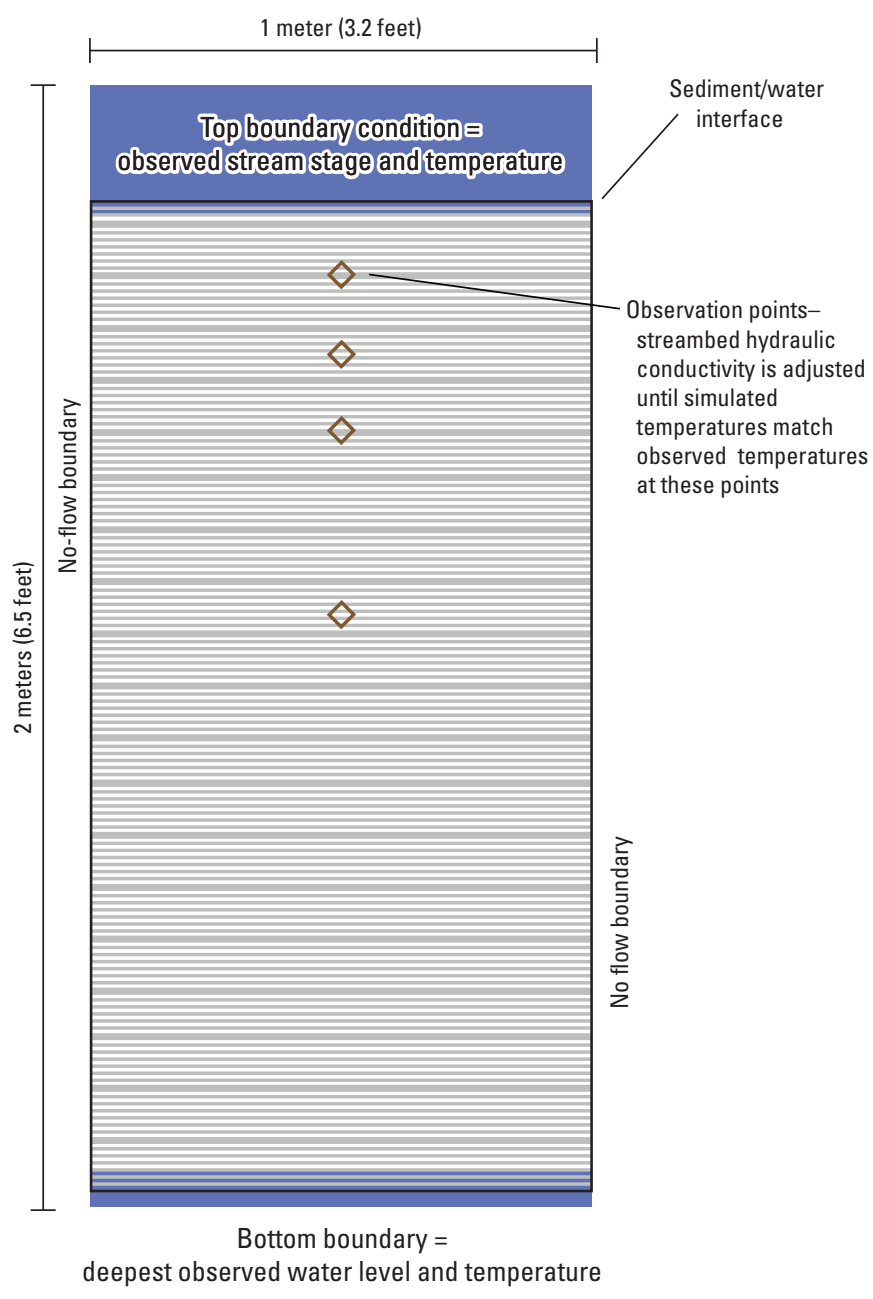

Figure 31. Framework for one-dimensional vertical modeling of water and heat flow through a streambed used in the VS2DH model. Vertical discretization is 0.01 meter. 


\section{Calibration}

Modeling, and subsequent calibration using heat as a tracer, was only possible at three of the six sites. At two sites, Orchard Road and West Stanislaus Road, sand bars developed at the location of the paired in-stream wells. Consequently, no stream stages or stream temperatures (top boundary condition requirement) were measured for the majority of the study period, and modeling was not possible at these sites. At the Patterson site, the equipment failed, so no data were available.

For the three remaining sites (Newman, Crows Landing, and Vernalis), two quantitative measures of model calibration were evaluated. The first measure of model calibration was the mass-balance error for fluid and energy associated with each model run, which is calculated internally by VS2DH (Healy and Ronan, 1996; Hsieh and others, 2000). Results from model simulations with a total mass-balance error of less than 1 percent for fluid and energy were considered acceptable. The second measure of model calibration was the model fit between measured and simulated streambed temperatures using the RMSE. Estimates of streambed hydraulic conductivity based on field observations during well installation and thermal conductivity values from the literature were input into the model until simulations visually fit the measured streambed temperatures at depth. The streambed hydraulic conductivity values were selected from a library of streambed textural classes ranging from medium sand $(1,310 \mathrm{ft} / \mathrm{d})$ to silty clay $(0.016 \mathrm{ft} / \mathrm{d})$, as included in the VS2DH software package.

The RMSE was calculated for each observation point, and an average of these values was used to compare the overall model fit for all observation points between model runs. The hydraulic conductivity value yielding a massbalance error of less than 1 percent with the lowest average RMSE was selected as the calibrated model. The calibrated models for all three sites produced simulated temperatures that matched observed temperatures reasonably well. The observed and simulated temperatures for each observation point, the measure of bias calculated as percentage difference between the simulated and observed temperature values, and associated calibrated RMSE values at the Newman (NRS), Crows Landing (CRS), and at Vernalis (VRS) sites are depicted in figures 32 , 33, and 34, respectively. The percentage difference was calculated as follows:

$$
\text { Percent difference }=\frac{T_{\text {sim }}-T_{o b s}}{T_{o b s}} \times 100 \text { percent }
$$

where

$T_{\text {sim }} \quad$ is the simulated temperature for a particular location and instant, and

$T_{\text {obs }}$ is the observed temperature for a particular location and instant.

The Newman site (fig. 32) had the best model fit, with RMSEs ranging from 0.13 to 0.58 and model fit decreasing with depth. The increase in RMSE values with depth indicates a decrease of vertical flow at depth, or a lateral flow component that the one-dimensional modeling approach did not account for. The range of RMSE values for the Crows Landing site (fig. 33), 0.66-1.62, was greater at the shallower depths (less than or equal to $1.5 \mathrm{ft}$ ), and the largest measure of bias calculated as percentage difference between the simulated and observed temperature values occurred during the 2007 winter base flows. Overall, the match between the simulated temperatures at the shallower depths to the observed temperatures was moderate for this site, indicating that this site does not fit the homogenous streambed sediments conceptual model.

At the Vernalis site (fig. 34), the model fit between simulated and observed temperatures improved with depth. Compared to other depths at this site, the site had the greatest measure of bias at the $0.5 \mathrm{ft}$-depth beginning in July 2007, continuing into the early part of October 2007, and again at the end of the data collection period in June 2008. This was likely the result of low-flow conditions at the location of the in-stream wells. During this time, the active stream channel was approximately 0.5-1 ft away from the wells (fig. 35). Manual water-level measurements of these wells during low-flow conditions recorded groundwater levels consistently above surface-water levels (by 0.4-0.8 ft). A seepage face was also visibly present at the base of the in-stream wells during low-flow conditions (fig. 35), indicating that although these wells were not in the active stream channel, there was still communication with the groundwater. 
San Joaquin River at Newman (NRS)
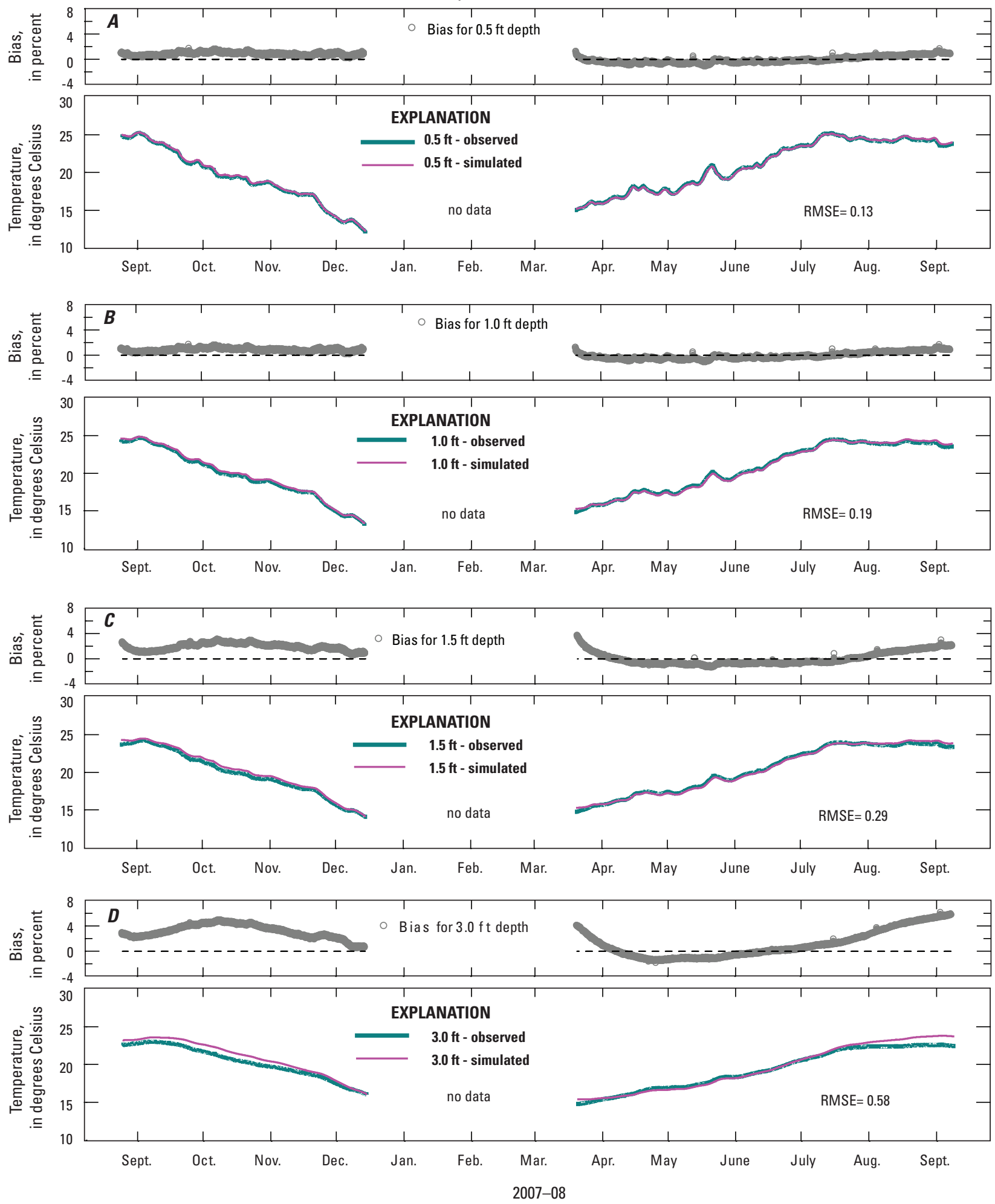

Figure 32. VS2DH modeling results for the Newman site, including simulated temperatures, measures of bias, and associated root mean-square error (RMSE) for observed temperatures at $A, 0.5$ foot below the streambed; $B, 1.0$ foot below the streambed; $C, 1.5$ feet below the streambed; and $D, 3.0$ feet below the streambed. 
San Joaquin River at Crows Landing (CRS)
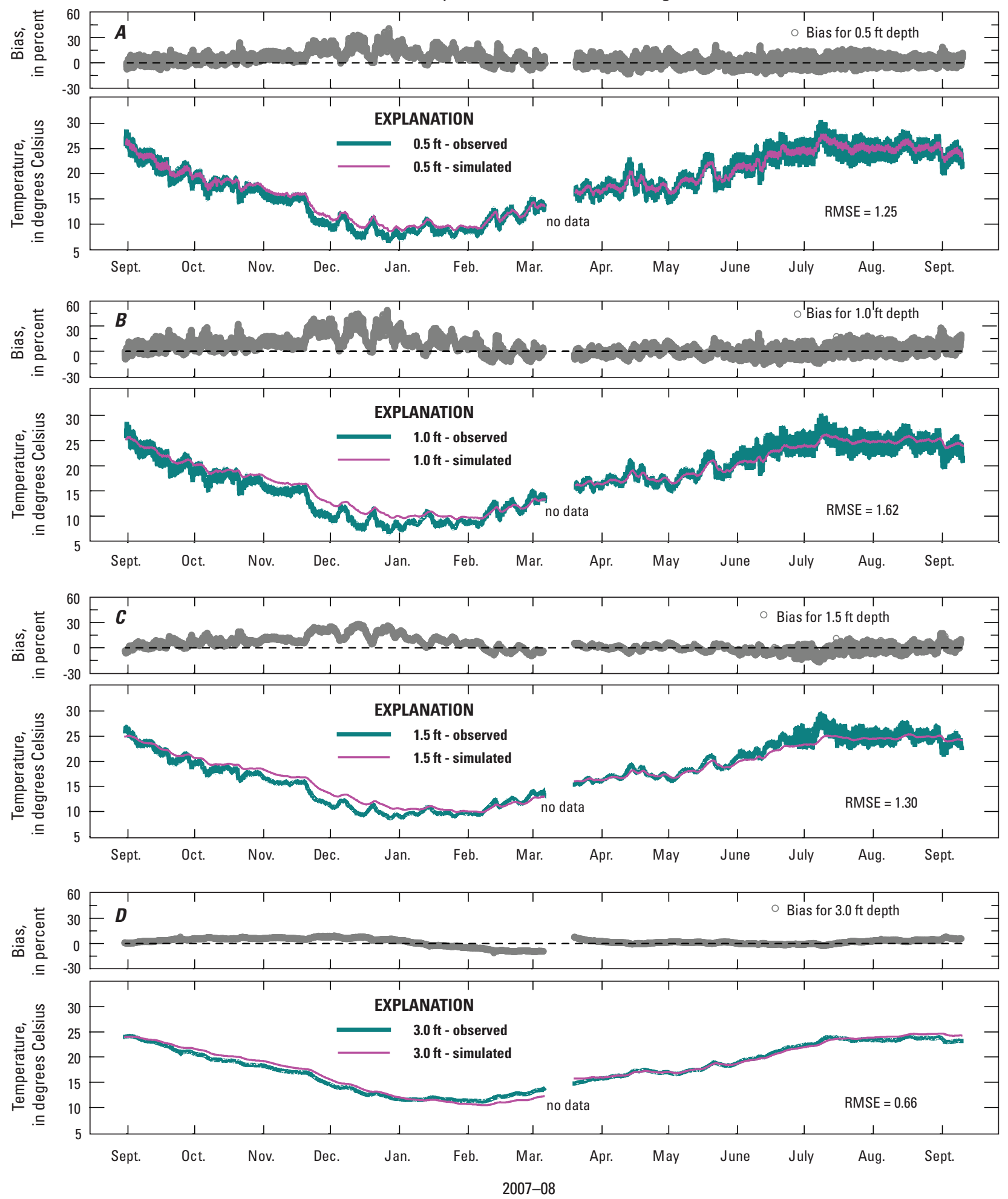

Figure 33. VS2DH modeling results for the Crows Landing site, including simulated temperatures, measures of bias, and associated root mean-square error (RMSE) for observed temperatures at $A, 0.5$ foot below the streambed; $B, 1.0$ foot below the streambed; $C, 1.5$ feet below the streambed; and $D, 3.0$ feet below the streambed. 
San Joaquin River at Vernalis (VRS)
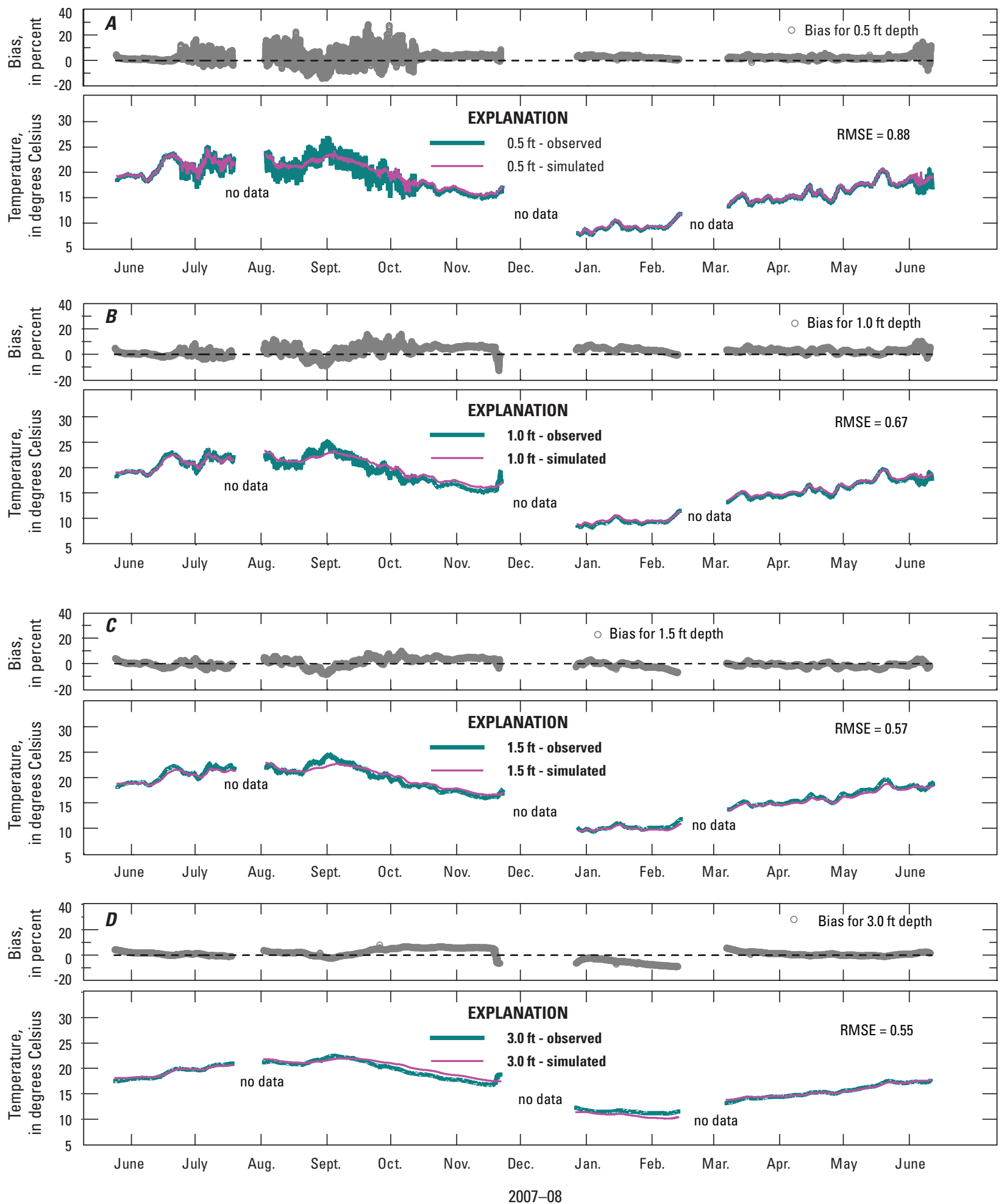

Figure 34. VS2DH modeling results for the Vernalis site, including simulated temperatures, measures of bias, and associated root mean-square error (RMSE) for observed temperatures at $A, 0.5$ foot below the streambed; $B, 1.0$ foot below the streambed; $C, 1.5$ feet below the streambed; and $D, 3.0$ feet below the streambed. 


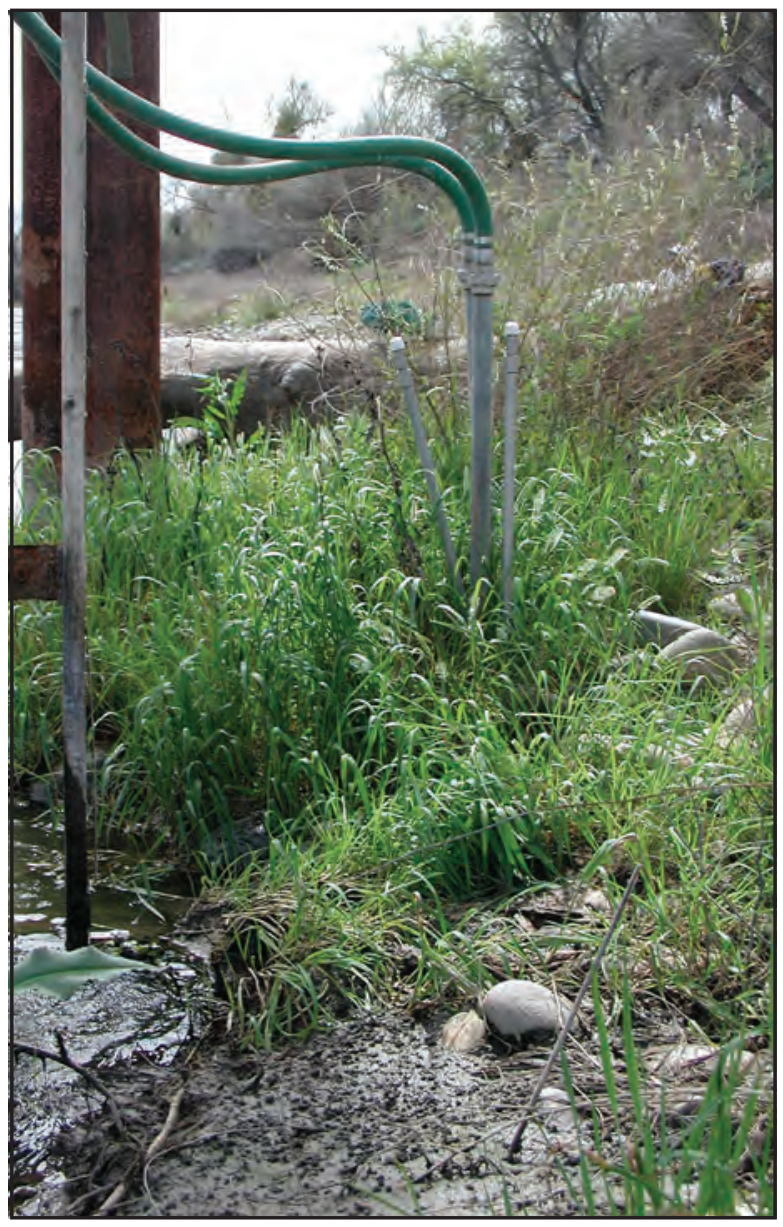

Figure 35. In-stream wells at the San Joaquin River at the Vernalis site during low-flow conditions. Photograph by Peter Dileanis, U.S. Geological Survey.

\section{Sensitivity Analysis}

The sensitivity of the models to calibrated parameters was determined during the model calibration process. The calibrated hydraulic conductivity value at each site was altered by factors of two and ten to test for sensitivity. The resultant difference between the observed and simulated temperatures was represented by an average of the RMSE values calculated for each observation point (table 7). The models were found to be insensitive to altering the calibrated hydraulic conductivity values by a factor of 2 , but they were more sensitive to changes that were a factor of 10 different from the calibrated value.

The streambed hydraulic conductivity was determined to have a one-to-one correspondence with streambed flux (river gain and river loss). If, for example, the streambed hydraulic conductivity is doubled, an identical solution could be obtained by doubling the fluxes; consequently, the value of streambed hydraulic conductivity was found to have a strong effect on the resulting streambed flux value. The calibrated streambed hydraulic conductivity values for the modeled sites ranged from 0.09 to 0.20 feet per day (table 7). Nearly identical solutions (as measured by the RMSE) were obtained when the hydraulic conductivity was altered by a factor of 2 . This indicated that the hydraulic conductivity value used in the models and the resulting estimates of streambed flux could vary by a factor of 2 . In some cases, the sensitivity analysis resulted in a RMSE value that was less than the calibrated RMSE value. The mass-balance error for fluid and energy associated with these model runs was greater than the acceptable 1 percent error, however, and results for these tests were regarded as invalid.

Table 7. Summary of sensitivity analysis performed on the in-stream wells modeled with heat as a tracer.

[Abbreviations ft, feet; ft/day, feet per day; K, hydraulic conductivity; RMSE, root mean square error; mm/dd/yyyy, month/day/year; x, multiplied by]

\begin{tabular}{|c|c|c|c|c|c|c|c|}
\hline \multirow{3}{*}{ Site } & \multirow{3}{*}{$\begin{array}{l}\text { Modeling periods } \\
\text { (mm/dd/yyyy) }\end{array}$} & \multicolumn{2}{|c|}{ Calibrated model values } & \multicolumn{4}{|c|}{ Sensitivity analysis, average RMSE$^{1}$ values } \\
\hline & & \multirow[b]{2}{*}{ Streambed K } & \multirow{2}{*}{$\begin{array}{l}\text { Average } \\
\text { RMSE }^{1}\end{array}$} & \multicolumn{2}{|c|}{ Factor of 2} & \multicolumn{2}{|c|}{ Factor of 10} \\
\hline & & & & $\begin{array}{c}\text { Streambed } \\
\quad \mathrm{K} \times 2\end{array}$ & $\begin{array}{l}\text { Streambed K } \\
\quad \times 0.5\end{array}$ & $\begin{array}{l}\text { Streambed K } \\
\times 10\end{array}$ & $\begin{array}{l}\text { Streambed K } \\
\text { x } 0.10\end{array}$ \\
\hline Newman (NRS) & $08 / 25 / 07$ to $12 / 14 / 07$ & $0.09 \mathrm{ft} / \mathrm{day}$ & 0.30 & 0.31 & 0.33 & 0.52 & 0.49 \\
\hline Newman (NRS) & 03/20/08 to $09 / 08 / 08$ & $0.09 \mathrm{ft} / \mathrm{day}$ & 0.30 & 0.31 & 0.33 & 0.52 & 0.49 \\
\hline Crows Landing (CRS) & $08 / 31 / 07$ to $03 / 06 / 08$ & $0.09 \mathrm{ft} /$ day & 1.21 & 1.24 & 1.20 & 1.32 & 1.12 \\
\hline Crows Landing (CRS) & $03 / 20 / 08$ to $09 / 10 / 08$ & $0.09 \mathrm{ft} /$ day & 1.21 & 1.24 & 1.20 & 1.32 & 1.12 \\
\hline Vernalis (VRS) & $08 / 02 / 07$ to $11 / 21 / 07$ & $0.20 \mathrm{ft} /$ day & 0.67 & 0.69 & 0.70 & 0.90 & 0.66 \\
\hline Vernalis (VRS) & $12 / 27 / 07$ to $02 / 13 / 08$ & $0.20 \mathrm{ft} /$ day & 0.67 & 0.69 & 0.70 & 0.90 & 0.66 \\
\hline Vernalis (VRS) & $03 / 07 / 08$ to $06 / 11 / 08$ & $0.20 \mathrm{ft} / \mathrm{day}$ & 0.67 & 0.69 & 0.70 & 0.90 & 0.66 \\
\hline
\end{tabular}

\footnotetext{
${ }^{1}$ Value represents the average of the individual RMSE values for each observation point at $0.5,1,1.5$, and $3 \mathrm{ft}$ below the streambed.
} 


\section{Model Results}

As a result of equipment failure, the data-collection periods for temperature and water level did not always coincide among sites and resulted in modeled periods that varied from site to site. In order to compare the streambed vertical flux values (river gain compared to river loss) for all sites, the distributions of river gains and river losses, in units of cubic feet per second per mile (cfs/mi), at each site were calculated for the irrigation and non-irrigation seasons. The irrigation season for the San Joaquin Valley typically starts in mid-March and ends in August-September. For the purposes of this report, the irrigation season is defined as starting on March 15 and ending on August 31. The modeled observations were distributed between each season at each site (fig. 36). A modeled observation is defined as the resultant calculated flux (river gain or river loss) for each unique temperaure and water-level observation collected. Temperature and waterlevel observations were collected every 30 minutes, resulting in approximately 48 unique values collected per day. These values were input into the model for each site and were output as modeled observations of vertical streambed flux.

The modeled flow rates at the Newman site (fig. 36A) were nearly an order of magnitude less compared to those observed at the two downstream sites. The in-stream wells at this location are in a very tight clay, and, therefore, flow rates potentially are not representative of the entire reach. The percentage of observations (discrete modeled output values from the collected temperature and water-level data input into model VS2DH model) for river gain during the irrigation season was greater than the percentage for the non-irrigation season. However, the average river gain during the nonirrigation season $(0.03 \mathrm{cfs} / \mathrm{mi})$ was slightly greater than during the irrigation season $(0.02 \mathrm{cfs} / \mathrm{mi})$, however. This happened because the modeled observations of river gain during the non-irrigation season were sometimes an order of magnitude greater than during the irrigation season. With the exception of the Newman site, it appeared that the irrigation season had little effect on the overall magnitude of river gain to the SJR. River gain during the irrigation season was slightly greater than during the non-irrigation season at the Crows Landing and Vernalis sites. At the Crows Landing site, the average river gain was $0.13 \mathrm{cfs} / \mathrm{mi}$ for the irrigation season and $0.11 \mathrm{cfs} / \mathrm{mi}$ for the non-irrigation season. The average river gain during the irrigation season at the Vernalis site was $0.18 \mathrm{cfs} / \mathrm{mi}$, compared to $0.16 \mathrm{cfs} / \mathrm{mi}$ during the non-irrigation season. The streambed sediment type, hydraulic conductivity value, and modeled vertical streambed flux values for each season at each site are summarized in table 8 .

The modeled vertical streambed fluxes and stream stages for the entire study period at the Newman, Crows Landing, and Vernalis sites are depicted in figure 37. This figure depicts the total observations for the irrigation and non-irrigation seasons. The Newman site had the least magnitude (less than plus or minus $0.1 \mathrm{cfs} / \mathrm{mi}$ ) of river gain and river loss during the irrigation season and non-irrigation season. The Crows Landing and Vernalis sites generally were gaining throughout the study period with distinct flow reversals during high-flow events associated with storm events or upstream dam releases.

The results of the modeling effort using heat as a tracer (VS2DH; table 8) were an order of magnitude less than those obtained using the MODFLOW approach. The MODFLOW approach estimated groundwater discharge rates to the SJR in two dimensions (horizontal and vertical), whereas the VS2DH approach estimated one-dimensional shallow streambed vertical flux as river gain or river loss at the location of the instream wells. Although this (VS2DH) method can be applied in two dimensions (vertical cross sections orientated perpendicular to the river), such an exercise was beyond the scope of this study.

\section{Model Limitations}

As with any modeling effort, there were uncertainties and limitations associated with the analysis. The onedimensional modeling approach for these sites simply estimates the streambed vertical flux in a point location within the streambed. The estimated rates can be extrapolated to larger areas only if the hydraulic gradient and the streambed hydraulic conductivity at that point are representative of the larger area where the in-stream monitoring wells are located. Although the locations of the in-stream wells were selected to be representative of the streambed sediments at each site, it is unlikely that the hydraulic conductivity values in a streambed are homogeneous and isotropic in an environment such as the SJR.

Simultaneously using temperature and water-level measurements made it possible to obtain modeled streambed fluxes. However, experience from this study showed that it can be challenging to obtain high-quality water-level measurements for both groundwater and river stage for monitoring wells installed in streambeds. It is difficult to forecast surface-water flow regimes and the effect that they can have on the data collected from monitoring wells installed in the streambed. Despite recent advances in data acquisition for water level and temperature, the data logging equipment and quality of data collected are limited by the diameter and the depths of the in-stream wells. For this type of study, most researchers use temperature logging devices that are 7/8 inch to 1 inch in diameter. For this study, however, the in-stream wells were 3/8 inches in diameter and were manually installed using a hydraulic post driver, which could smear the finegrained materials to deeper depths. The use of alternate water level and temperature logging equipment proved to be problematic for data logging reliability at several sites. 

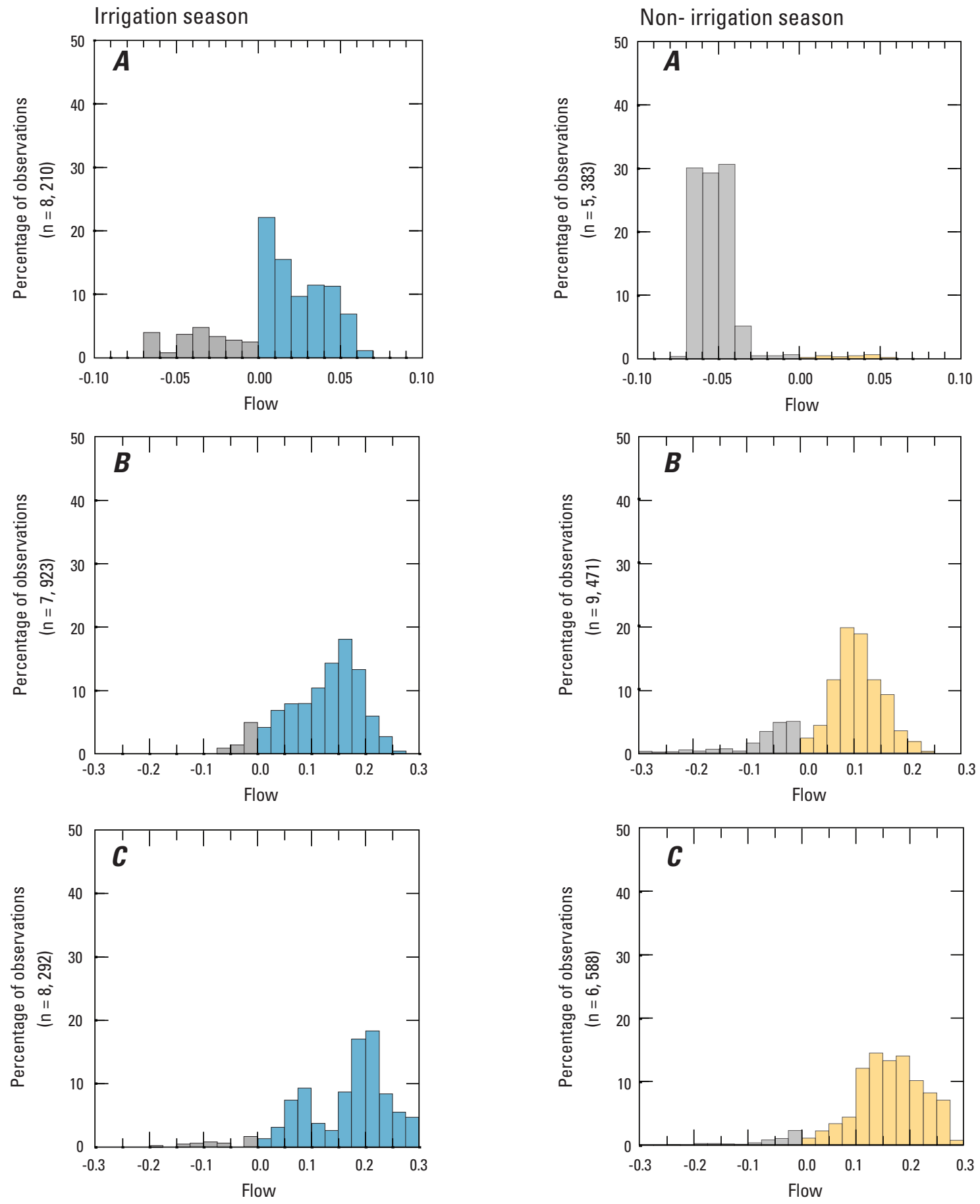

EXPLANATION

$\mathrm{n}$ represents the number of samples

EXPLANATION

$\mathrm{n}$ represents the number of samples

$\square$ River gain

$\square$ River gain

River loss

River loss

Figure 36. Distribution of river gain and river loss in cubic feet per second per mile during the irrigation and non-irrigation seasons for the $A$, Newman; $B$, Crows Landing; and $C$, Vernalis sites. 

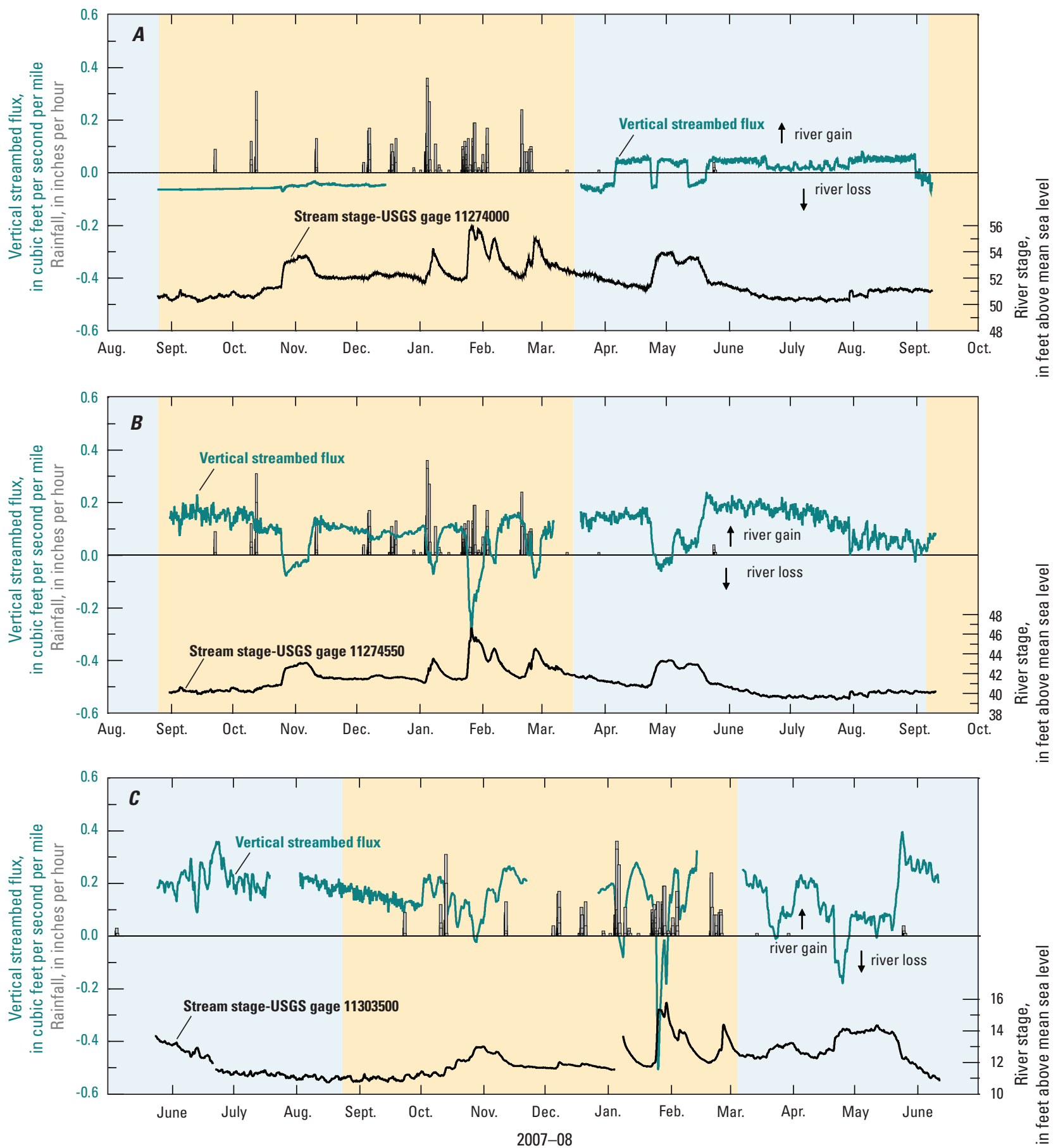

EXPLANATION

USGS U.S. Geological Survey

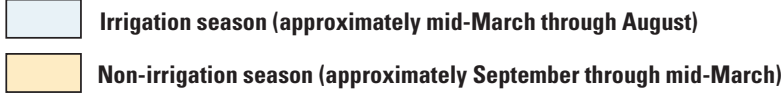

Figure 37. Stream stage and modeled vertical streambed flux (in cubic feet per second per mile) using heat as a tracer at $A$, Newman; $B$, Crows Landing; and $C$, Vernalis sites. 
Table 8. Summary of streambed sediment textures, streambed hydraulic conductivity, and average vertical streambed flux values for the non-irrigation and irrigation seasons.

[Positive vertical streambed flux values are presented as river gain and negative vertical streambed flux values are presented as river loss]

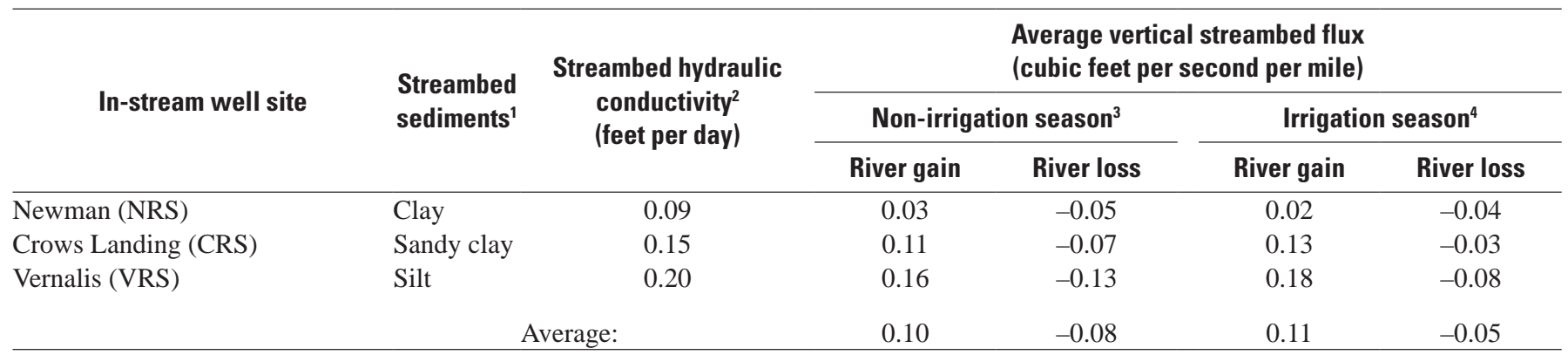

${ }^{1}$ Refers to textural class used in VS2DH model for calibrated model.

${ }^{2}$ Represents value assigned to chosen textural class in the VS2DH textural class library.

${ }^{3}$ Assigned to flux values modeled between September 1 through March 14.

${ }^{4}$ Assigned to flux values modeled between March 15 through August 31.

\section{Streambed Hydraulic Gradients}

Four times during the study period (Synoptics IIV), measurements of streambed hydraulic gradients and groundwater SC were made at 113 transects in the 59-mi study reach (86 transects measured at least once, and 27 transects measured multiple times). The interaction of groundwater with surface water was evaluated using measured hydraulic gradients and SC values at each transect (figs. 20-23).

\section{Synoptic I-August-September 2007}

The focus of the first synoptic was to gain an overall understanding of the hydraulic gradients between the SJR and the shallow groundwater along the 59-mi reach (river miles 131.5 to 72.0 , fig. 20). The hydraulic gradients and SC values for the 30 transects are depicted by depth and river mile in figure 38 . Of the 120 hydraulic gradient measurements made at both depths ( 1 and $3 \mathrm{ft}$ ), 65.8 percent were gaining (river gain), 21.7 percent were losing (river loss), and 12.5 percent were neutral. The highest SC measurements - 12.60 millisiemens per centimeter $(\mathrm{mS} / \mathrm{cm})$ and $10.48 \mathrm{mS} / \mathrm{cm}$-were at river miles 127.5 and 125.3, respectively. These sites also corresponded to the most negative hydraulic gradients.

Measurements were made at five transects next to the WWTP ponds and fields in which the treated water is land applied (river miles 96.0 to 93.5, fig. 20). The focus of the synoptic in this 2.5-mi reach was to examine areas of potential positive hydraulic gradients (river gain) and potential differences in SC resulting from the WWTP. The average hydraulic gradient for this area was slightly gaining, $0.004 \mathrm{ft} / \mathrm{ft}$, with three neutral gradients measured. The average SC value for these 5 transects (20 total measurements) was $1.74 \mathrm{mS} / \mathrm{cm}$ for the combined 1- and 3-ft depths and was lower than the average SC for the remaining 25 transects, which was $3.67 \mathrm{mS} / \mathrm{cm}$ at the $1-\mathrm{ft}$ depth and $3.88 \mathrm{mS} / \mathrm{cm}$ at the 3-ft depth.

\section{Synoptic II-August 2008}

In the second synoptic, a total of 30 transects (11 new transects) were measured (fig. 21). The emphasis of this synoptic was to revisit the five areas of interest found during Synoptic I sampling. The areas of interest included transects with the highest upward gradients (river miles 118.7, 110.0, and 91.1), areas with unexpectedly high SC values (river miles 84.1, 127.5, 125.3), and revisiting the transects near the WWTP (river miles 96 to 93.5). Overall, of the 179 hydraulic gradients measured at both depths ( 1 and $6 \mathrm{ft}$ ) during Synoptic II, 60.3 percent were gaining, 29.6 percent were losing, and 10.1 percent were neutral (fig. 39).

A comparison of hydraulic gradients and SC values for those transects that were measured during Synoptics I and II is presented in table 9. There was little consistency in hydraulic gradients measured between the two synoptics for the areas of interest; only one of the four transects revisited remained gaining (transect at river mile 91.1), and one remained losing (transect at river mile 125.3). The SCs measured in groundwater also varied between the two synoptics, with the exception of the deeper depths at the east bank of river mile 110.0. The high variability in SC values for the six transects that were sampled in both synoptics made it difficult to interpret an overall trend in the data; the average change between Synoptic I and Synoptic II was a decrease of 6.2 percent, with a standard deviation of plus or minus 67.9 percent. The SC values in the SJR itself also decreased between Synoptic I and Synoptic II (for the five transects with data from the SJR, table 9), with decreases ranging from 10.2 to 31.8 percent. 
Synoptic I

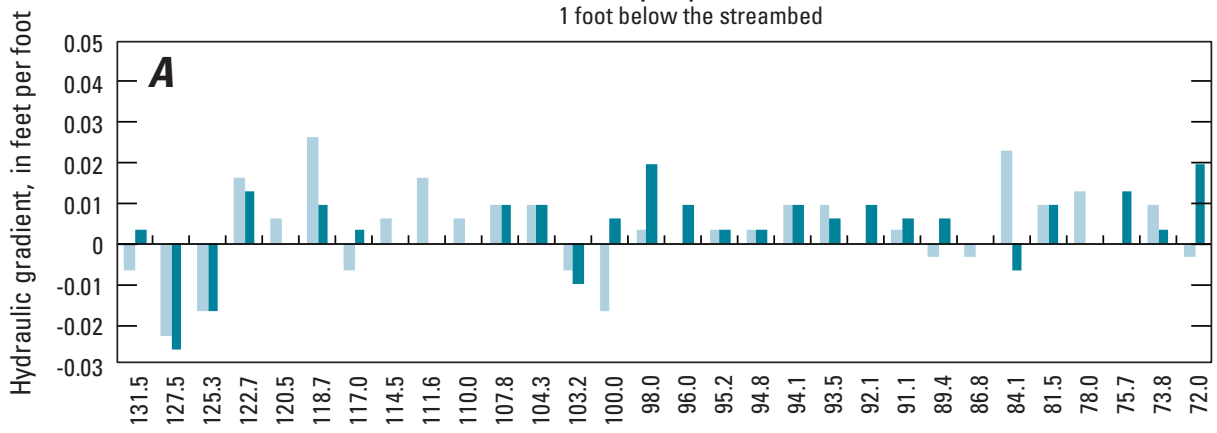

EXPLANATION

$\square$ West bank

East bank

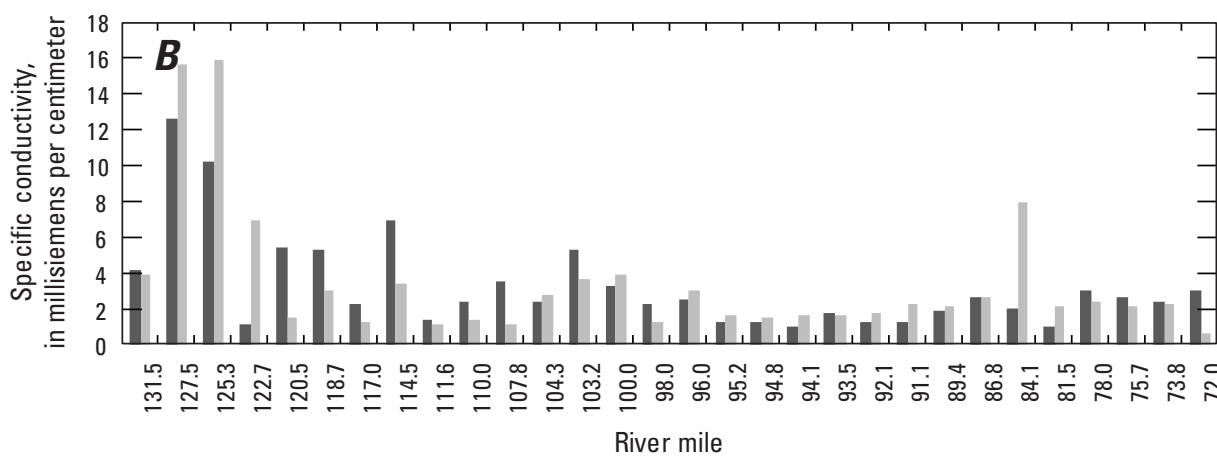

EXPLANATION

East bank

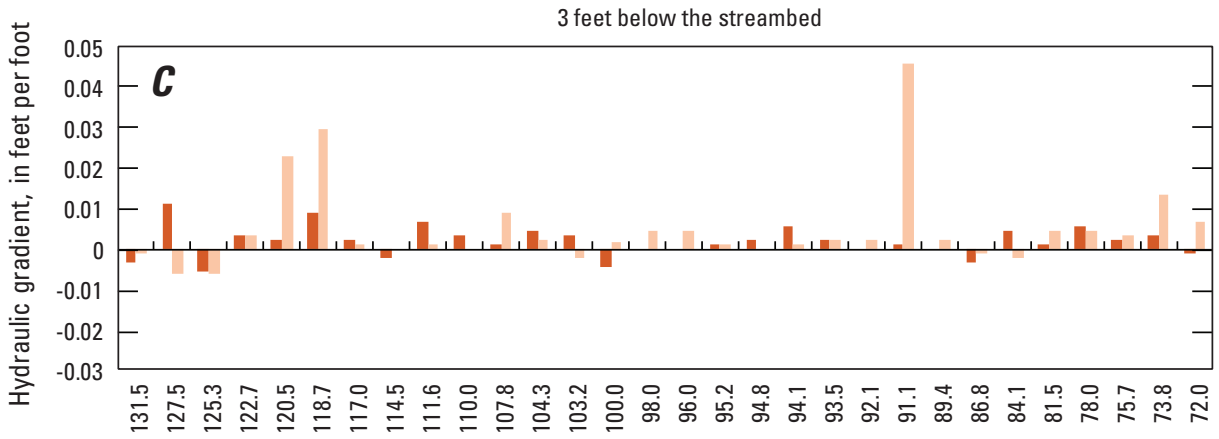

EXPLANATION

West bank

East bank

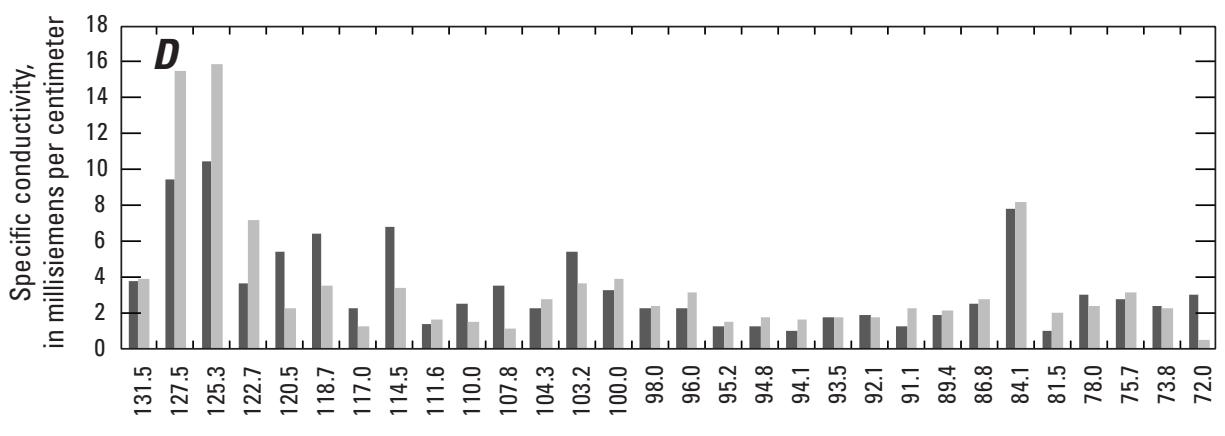

EXPLANATION

River mile

Figure 38. Measured values Synoptic I, August-September 2007, of $A$, hydraulic gradients and $B$, specific conductivity at 1 foot below the streambed; and $C$, hydraulic gradients and $D$, specific conductivity at 3 feet below the streambed. 
Synoptic II

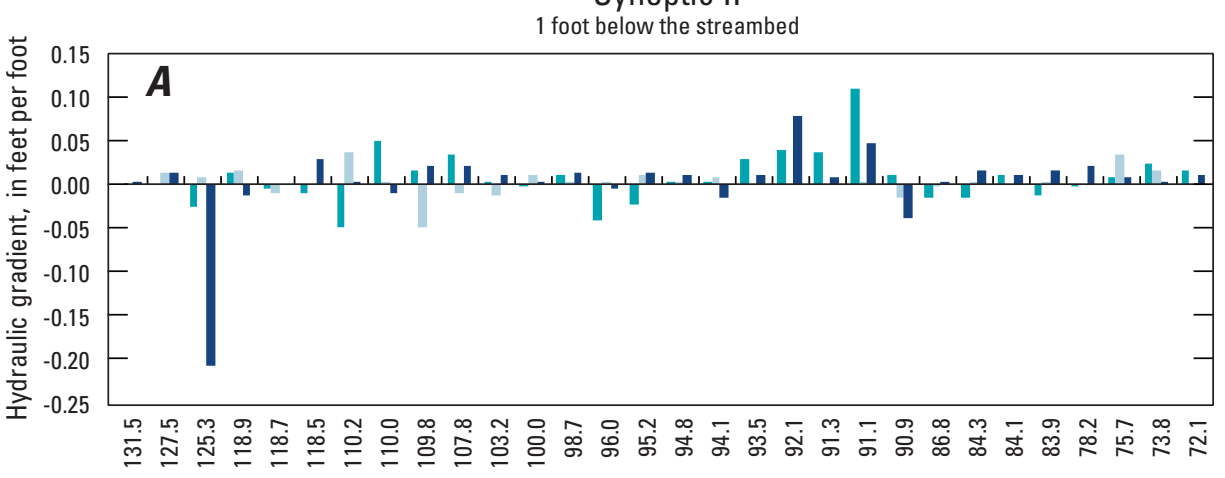

EXPLANATION

West bank

Middle

East bank

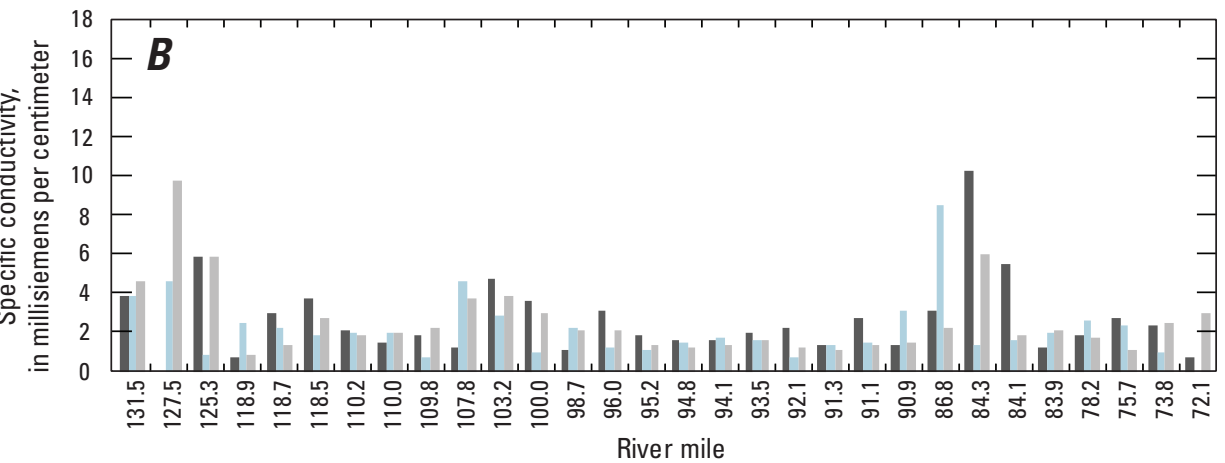

EXPLANATION

$\square$ West bank

Middle

East bank

low the streambed

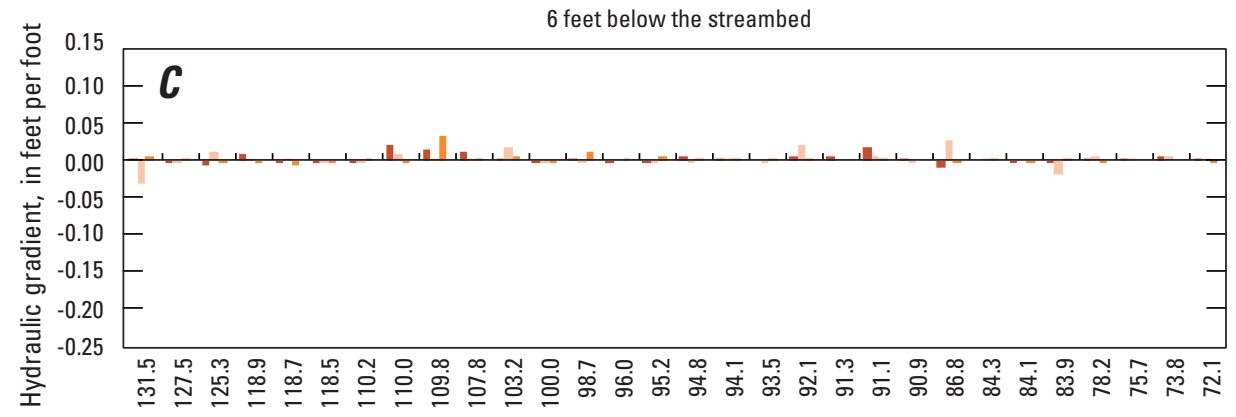

EXPLANATION

Middle

East bank

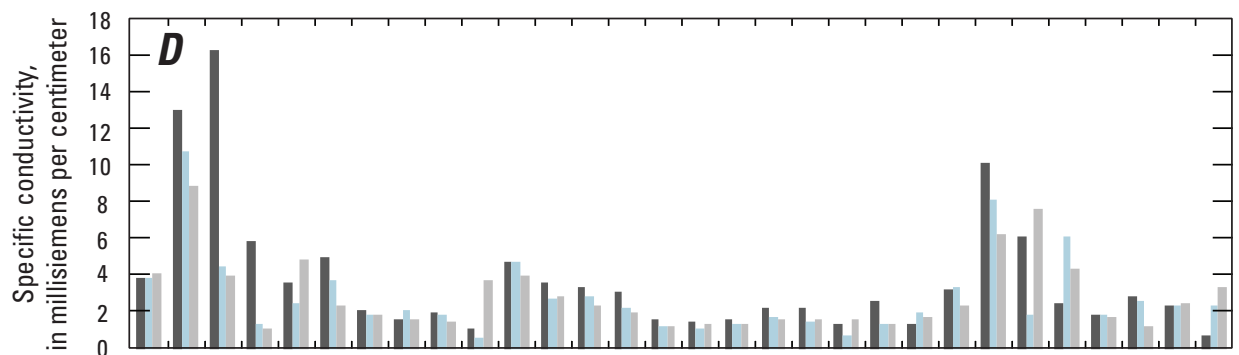

EXPLANATION

West bank

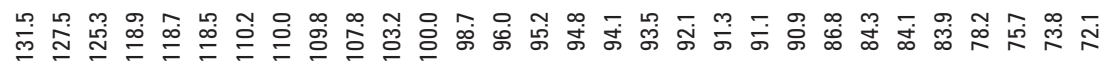

River mile

Figure 39. Measured values from Synoptic II, August 2008, of $A$, hydraulic gradients and $B$, specific conductivity at 1 foot below the streambed; and $C$, hydraulic gradients and $D$, specific conductivity at 6 feet below the streambed. 
Table 9. Comparison of hydraulic gradient and specific conductivity values measured during Synoptic I and Synoptic II.

[Abbreviations $\mathrm{ft}$, feet; ft/ft, feet per foot; $\mathrm{mS} / \mathrm{cm}$, millisiemens per
centimeter; SJR, San Joaquin River; -, no measurement made because of deep
water]

\begin{tabular}{|c|c|c|c|c|c|c|c|}
\hline \multirow{2}{*}{ Synoptic } & \multirow{2}{*}{$\begin{array}{c}\text { River } \\
\text { mile }\end{array}$} & \multirow{2}{*}{$\begin{array}{c}\text { West bank } \\
\text { or east } \\
\text { bank }^{1}\end{array}$} & \multicolumn{2}{|c|}{$\begin{array}{l}\text { Hydraulic } \\
\text { gradient, } \\
\text { in } \mathrm{ft} / \mathrm{ft}\end{array}$} & \multicolumn{2}{|c|}{$\begin{array}{c}\text { Specific } \\
\text { conductivity, } \\
\text { in } \mathrm{mS} / \mathrm{cm}\end{array}$} & \multirow{2}{*}{$\begin{array}{c}\text { SJR } \\
\text { specific } \\
\text { conductivity } \\
\text { in } \mathrm{mS} / \mathrm{cm}\end{array}$} \\
\hline & & & $\begin{array}{c}1 \mathrm{ft} \\
\text { depth }\end{array}$ & $\begin{array}{l}\text { 23-6 ft } \\
\text { depth }\end{array}$ & $\begin{array}{c}1 \mathrm{ft} \\
\text { depth }\end{array}$ & $\begin{array}{l}{ }^{23-6} \mathrm{ft} \\
\text { depth }\end{array}$ & \\
\hline I & 127.5 & West bank & -0.006 & -0.026 & 15.6 & 15.5 & 1.25 \\
\hline II & 127.5 & East bank & 0.013 & 0.002 & 9.74 & 8.88 & 1.03 \\
\hline I & 125.3 & West bank & -0.016 & -0.005 & 10.3 & 10.5 & 1.30 \\
\hline II & 125.3 & West bank & -0.026 & -0.007 & 5.86 & 16.3 & 1.09 \\
\hline I & 125.3 & East bank & -0.016 & -0.007 & 15.8 & 15.9 & 1.31 \\
\hline II & 125.3 & East bank & -0.207 & -0.004 & 5.86 & 4.00 & 1.09 \\
\hline I & 118.7 & West bank & 0.026 & 0.009 & 5.29 & 6.44 & 1.20 \\
\hline II & 118.7 & West bank & -0.007 & -0.003 & 2.96 & 3.57 & 0.82 \\
\hline I & 118.7 & East bank & 0.010 & 0.030 & 3.01 & 3.50 & 1.19 \\
\hline II & 118.7 & East bank & 0.000 & -0.008 & 1.30 & 4.81 & 0.82 \\
\hline I & 110.0 & West bank & 0.007 & 0.003 & 2.43 & 2.45 & 1.07 \\
\hline II & 110.0 & West bank & 0.049 & 0.019 & 1.44 & 1.57 & 0.88 \\
\hline I & 110.0 & East bank & 0.000 & 0.000 & 1.34 & 1.57 & 1.07 \\
\hline II & 110.0 & East bank & -0.010 & -0.002 & 1.95 & 1.57 & 0.88 \\
\hline I & 91.1 & West bank & 0.003 & 0.001 & 1.29 & 1.30 & - \\
\hline II & 91.1 & West bank & 0.108 & 0.018 & 2.74 & 2.66 & 1.04 \\
\hline I & 91.1 & East bank & 0.007 & 0.046 & 2.29 & 2.22 & - \\
\hline II & 91.1 & East bank & 0.046 & 0.001 & 1.30 & 1.29 & 1.04 \\
\hline I & 84.1 & West bank & 0.023 & 0.004 & 1.97 & 7.86 & 1.18 \\
\hline II & 84.1 & West bank & 0.010 & -0.004 & 5.54 & 6.09 & 1.06 \\
\hline I & 84.1 & East bank & -0.007 & -0.002 & 7.94 & 8.19 & 1.19 \\
\hline II & 84.1 & East bank & 0.010 & -0.002 & 1.88 & 7.64 & 1.06 \\
\hline
\end{tabular}

${ }^{1}$ Although measurements were also made in the middle of the transects during Synoptic II, only the west bank and east bank values are presented for comparison purposes.

${ }^{2}$ The depth of measurement for Synoptic I was $3 \mathrm{ft}$ and depth of measurement for Synoptic II was $6 \mathrm{ft}$.
The measured hydraulic gradient and SC values in the five transects surrounding the WWTP are compared in table 10. Only one of the five transects revisited during Synoptic II remained gaining (river mile 94.1). Hydraulic gradient and SC measurements could not be made on the west bank of river mile 93.5 because of deep water that prevented measurements, but the east bank measurements remained unchanged between the two synoptics. The SC measured in groundwater at the transects near the WWTP remained relatively unchanged at both depths. The range of relative percentage differences between SC measured during Synoptic I and II (for the five transects) was -15 percent (decrease) to 33 percent (increase). Although the average change, 1.1 percent, was a slight increase, the standard deviation of this average was plus or minus 13.4 percent, indicating a mixture of increases and decreases throughout this set of transects.

\section{Synoptic III—September 2008}

The focus of the third synoptic was to examine longitudinal variability in the areas immediately upstream and downstream of the six well sites (fig. 22). Transect measurements were planned for two depths ( 1 and $6 \mathrm{ft}$ ) at the midpoints of each transect at each well site, at two transects upstream of each well site, and at two transects downstream from each bank well or in-stream well site (for well site locations, see fig. 15). During the third synoptic, 27 of these 30 planned transects were measured. Transect measurements could not be made at river miles 107.2, 107.1, and 72.2 because the river was too deep to wade. Most of the hydraulic gradients measured during Synoptic III were generally positive, indicating river gain, with slight variability between depths and between transects at the three most upstream sites (fig. 40): West Stanislaus Road (site D), Orchard Road (site E), and Vernalis (site F). Measured hydraulic gradients at the most downstream sites-Newman (site A), Crows Landing (site B), and Patterson (site $\mathrm{C}$ )—had greater variability between depths 
and among transects (fig. 40). The measured SC values at the 1- and 6-ft depths were similar to each other, indicating that there is little mixing of surface water with groundwater in the shallow depths of the streambed at these sites. The average SC measured in the SJR (surface water) during Synoptic III was $1.17 \mathrm{mS} / \mathrm{cm}$, whereas the average SC values for the shallow and deep depths were 3.56 and $4.13 \mathrm{mS} / \mathrm{cm}$, respectively.

\section{Synoptic IV—June 2009}

In the final synoptic, 56 transects (includng 52 new transects not sampled in previous synoptics) were made in 3 areas of elevated SC discovered in the previous synoptics (fig. 23). The three areas were between Salt Slough and Mud Slough (river miles 128.8 to 122.2 , defined as area 1), upstream of the Tuolumne River (river miles 86 to 84, defined as area 2), and between the Tuolumne and Stanislaus Rivers (river miles 80.9 to 78.2 , defined as area 3; figs. 41-43). SC measurements were made at two depths ( 1 and $3 \mathrm{ft}$ ) at the midpoints of each transect. The goal of this synoptic was to better define the longitudinal extent of the high SC between Salt Slough and Mud Slough and to examine the source and extent of the elevated SC values in the latter two areas.

The SC values measured at both depths between Salt Slough and Mud Slough (area 1, river miles 128.8 to 122.2) were the greatest of the three areas measured during Synoptic IV. This area receives highly saline tile drainage in the nearby Grasslands Drainage Area (Letey and others, 2002; San Joaquin Valley Drainage Program, 2009). The SC values ranged from 0.83 to $17 \mathrm{mS} / \mathrm{cm}$ (fig. 41). The SC values measured in area 2 and area 3 were lower relative to those measured in area 1, with the exceptions of elevated SC values measured on the east bank between river miles 84.5 to 84.0 (area 2, fig. 42) and between river miles 79.2 to 78.5 (area 3, fig. 43). Overall, the SC values measured at the 1 - and $3-\mathrm{ft}$ depths in Synoptic IV for all three areas were very similar to each other, indicating that there is little mixing of surface water with the groundwater below the streambed.
Table 10. Comparison of hydraulic gradient and specific conductivity values measured during Synoptic I and during Synoptic II in transects near the wastewater-treatment plant ponds.

[Abbreviations $\mathrm{ft}$, feet; $\mathrm{ft} / \mathrm{ft}$, feet per foot; $\mathrm{mS} / \mathrm{cm}$, millisiemens per centimeter; SJR, San Joaquin River; -, no measurement made because of deep water]

\begin{tabular}{|c|c|c|c|c|c|c|c|}
\hline \multirow[t]{2}{*}{ Synoptic } & \multirow{2}{*}{$\begin{array}{l}\text { River } \\
\text { mile }\end{array}$} & \multirow{2}{*}{$\begin{array}{c}\text { West bank } \\
\text { or east } \\
\text { bank }^{1}\end{array}$} & \multicolumn{2}{|c|}{$\begin{array}{l}\text { Hydraulic } \\
\text { gradient, } \\
\text { in } \mathrm{ft} / \mathrm{ft}\end{array}$} & \multicolumn{2}{|c|}{$\begin{array}{c}\text { Specific } \\
\text { conductivity, } \\
\text { in } \mathrm{mS} / \mathrm{cm}\end{array}$} & \multirow{2}{*}{$\begin{array}{c}\text { SJR } \\
\text { specific } \\
\text { conductivity } \\
\text { in } \mathrm{mS} / \mathrm{cm}\end{array}$} \\
\hline & & & $\begin{array}{c}1 \mathrm{ft} \\
\text { depth }\end{array}$ & $\begin{array}{l}\text { 23-6 ft } \\
\text { depth }\end{array}$ & $\begin{array}{c}1 \mathrm{ft} \\
\text { depth }\end{array}$ & $\begin{array}{l}{ }^{23-6 \mathrm{ft}} \\
\text { depth }\end{array}$ & \\
\hline I & 96.0 & West bank & 0.010 & 0.004 & 3.07 & 3.11 & 1.25 \\
\hline II & 96.0 & West bank & -0.043 & -0.002 & 3.13 & 3.05 & 0.98 \\
\hline I & 96.0 & East bank & 0.000 & 0.000 & 2.49 & 2.31 & 1.26 \\
\hline II & 96.0 & East bank & -0.007 & 0.001 & 2.13 & 1.96 & 0.98 \\
\hline I & 95.2 & West bank & 0.003 & 0.001 & 1.60 & 1.57 & 1.25 \\
\hline II & 95.2 & West bank & -0.023 & -0.001 & 1.85 & 1.61 & 1.02 \\
\hline I & 95.2 & East bank & 0.003 & 0.001 & 1.24 & 1.22 & 1.28 \\
\hline II & 95.2 & East bank & 0.013 & 0.004 & 1.29 & 1.27 & 1.02 \\
\hline I & 94.8 & West & & & 1.56 & 1.78 & 1.25 \\
\hline II & 94.8 & West bank & 0.003 & 0.004 & 1.60 & 1.52 & 1.02 \\
\hline I & 94.8 & East bank & 0.003 & 0.002 & 1.30 & 1.26 & 1.27 \\
\hline II & 94.8 & East bank & 0.010 & 0.003 & 1.23 & 1.30 & 1.02 \\
\hline I & 94.1 & West bank & 0.010 & & 1.64 & 1.68 & 1.27 \\
\hline II & 94.1 & West bank & 0.003 & 0.001 & 1.61 & 1.60 & 1.03 \\
\hline I & 94.1 & East bank & 0.010 & 0.005 & 1.05 & 1.06 & 1.27 \\
\hline II & 94.1 & East bank & -0.016 & 0.003 & 1.40 & 1.36 & 1.03 \\
\hline I & 93.5 & West bank & - & - & - & - & - \\
\hline II & 93.5 & West bank & - & - & - & - & - \\
\hline I & 93.5 & East bank & 0.010 & 0.002 & 1.75 & 1.74 & 1.27 \\
\hline II & 93.5 & East bank & 0.010 & 0.002 & 1.58 & 1.60 & 1.03 \\
\hline
\end{tabular}

${ }^{1}$ Although measurements were also made in the middle of the transects during Synoptic II, only the west bank and east bank values are presented for comparison purposes.

${ }^{2}$ The depth of measurement for Synoptic I was $3 \mathrm{ft}$ and depth of measurement for Synoptic II was $6 \mathrm{ft}$. 
$\boldsymbol{A}$

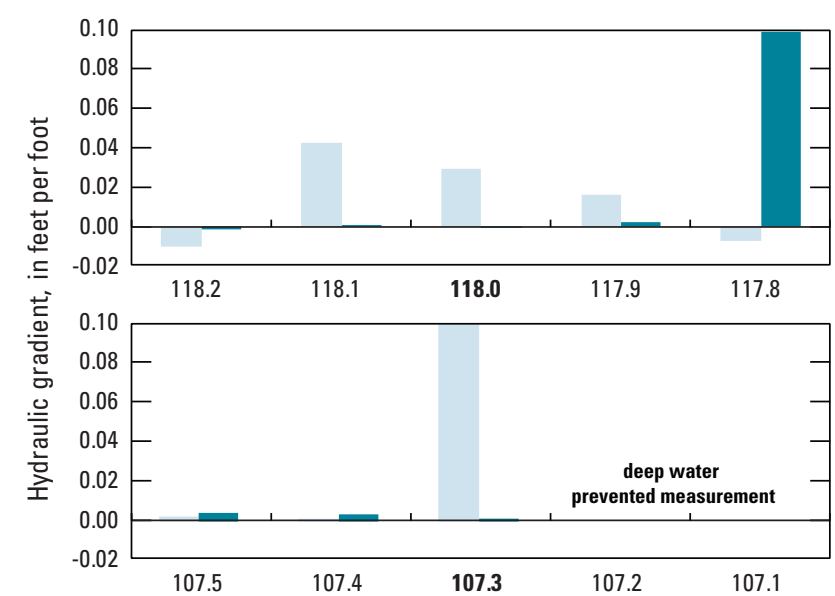

C

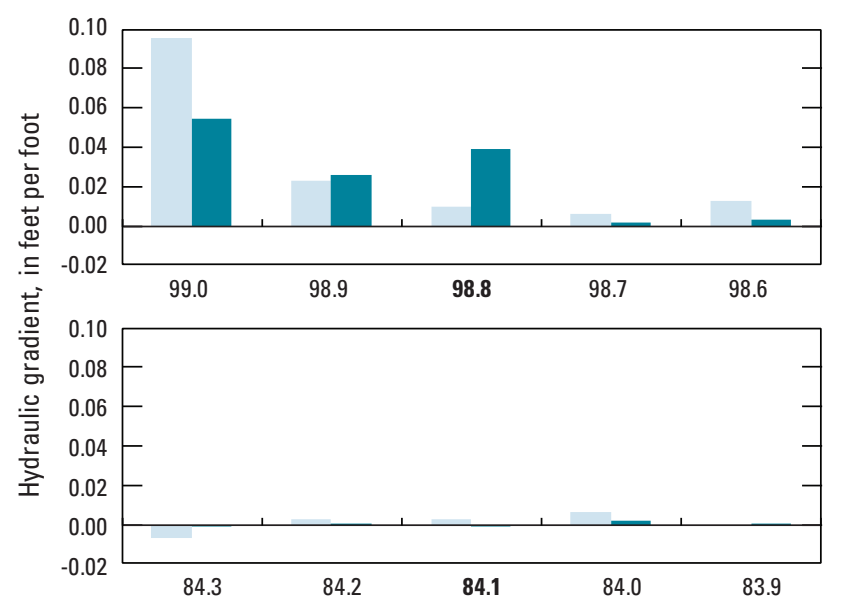

$\boldsymbol{E}$

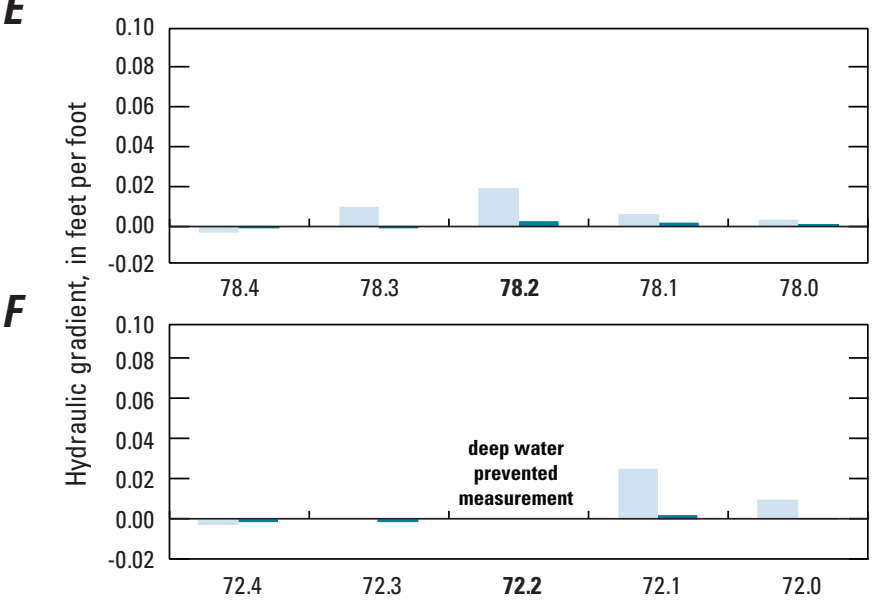

EXPLANATION

Middle -1 foot below streambed

Middle -6 feet below streambed

Synoptic III
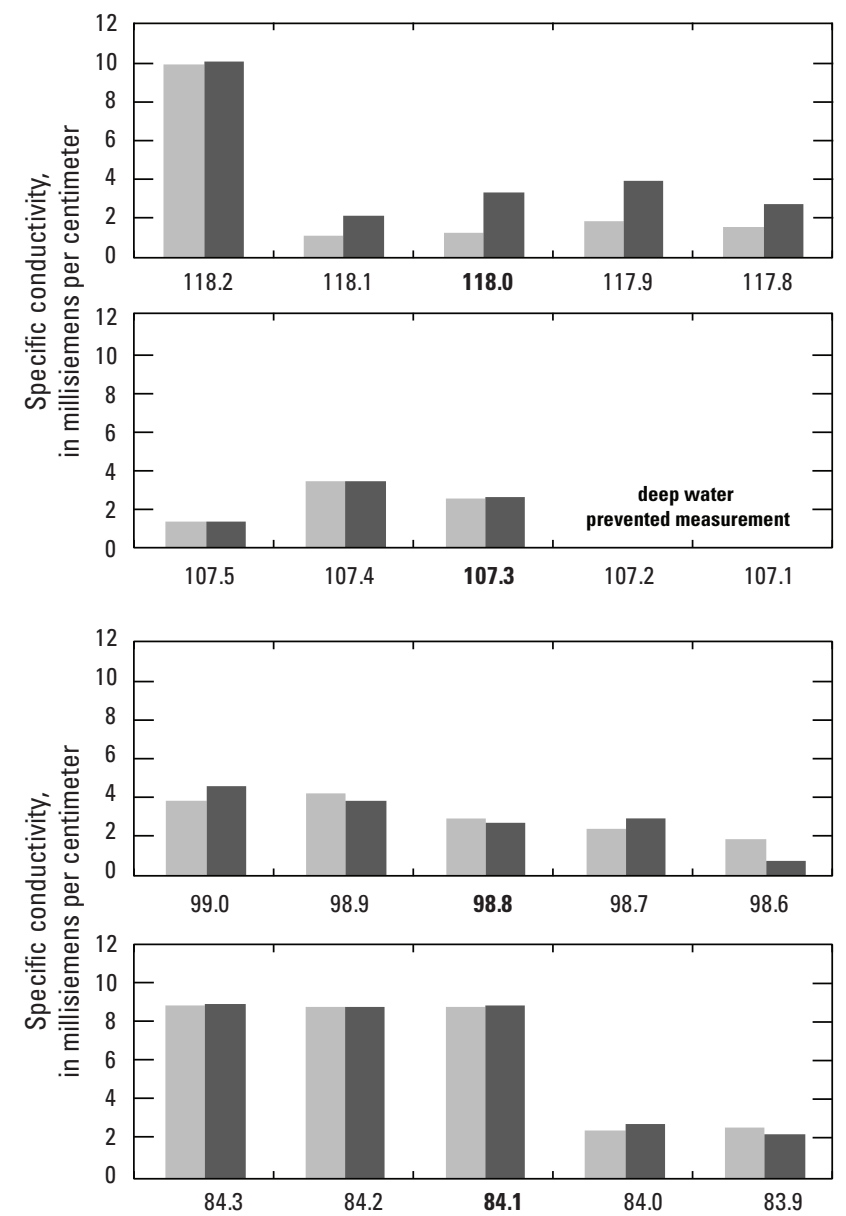

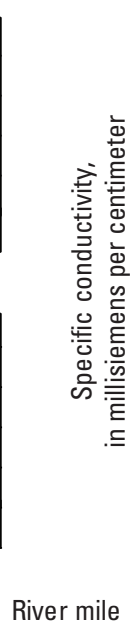

River mile
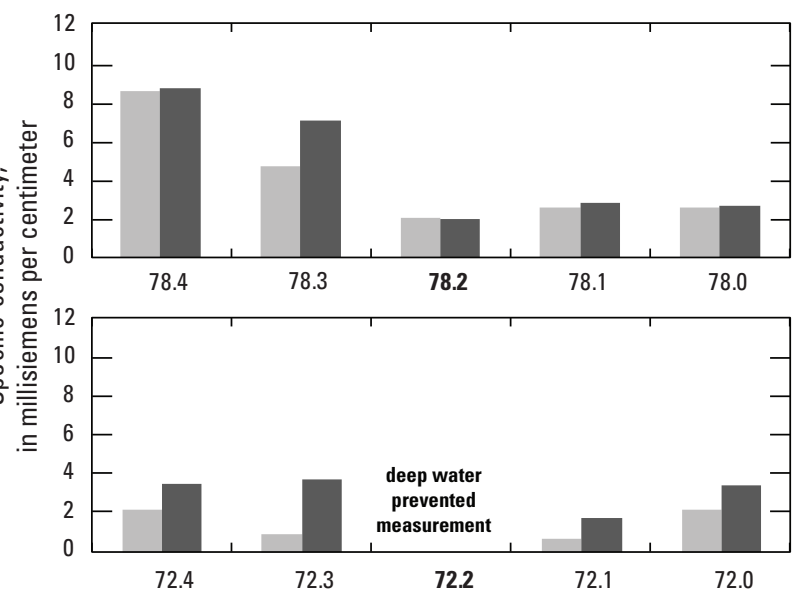

EXPLANATION

Middle -1 foot below streambed

Middle -6 feet below streambed

Figure 40. Hydraulic gradients and specific conductivity measured during Synoptic III, September 2008, at the $A$, Newman; $B$, Crows Landing; $C$, Patterson; $D$, West Stanislaus Road; $E$, Orchard Road; and $F$, Vernalis sites. 
Synoptic IV

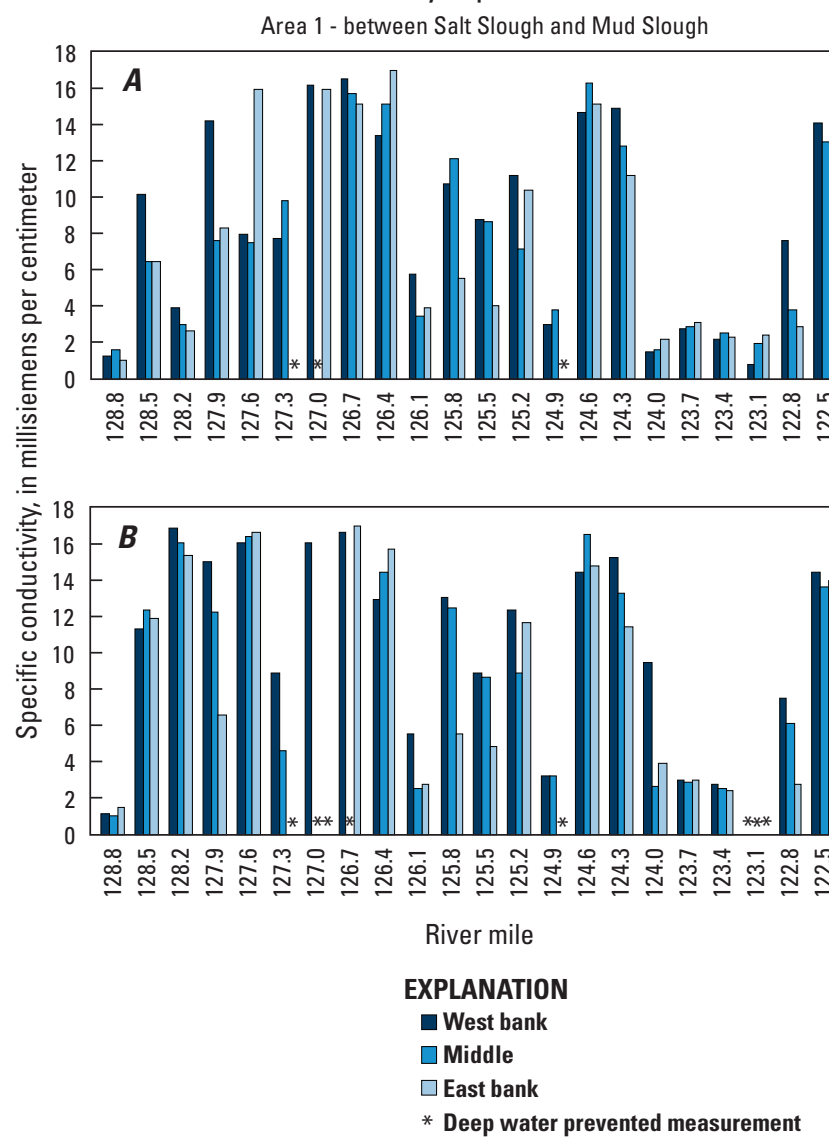

Figure 41. Specific conductivity values measured in area 1 during Synoptic IV, June 2009, at $A$, 1-foot depth and $B$, 3-feet depth.

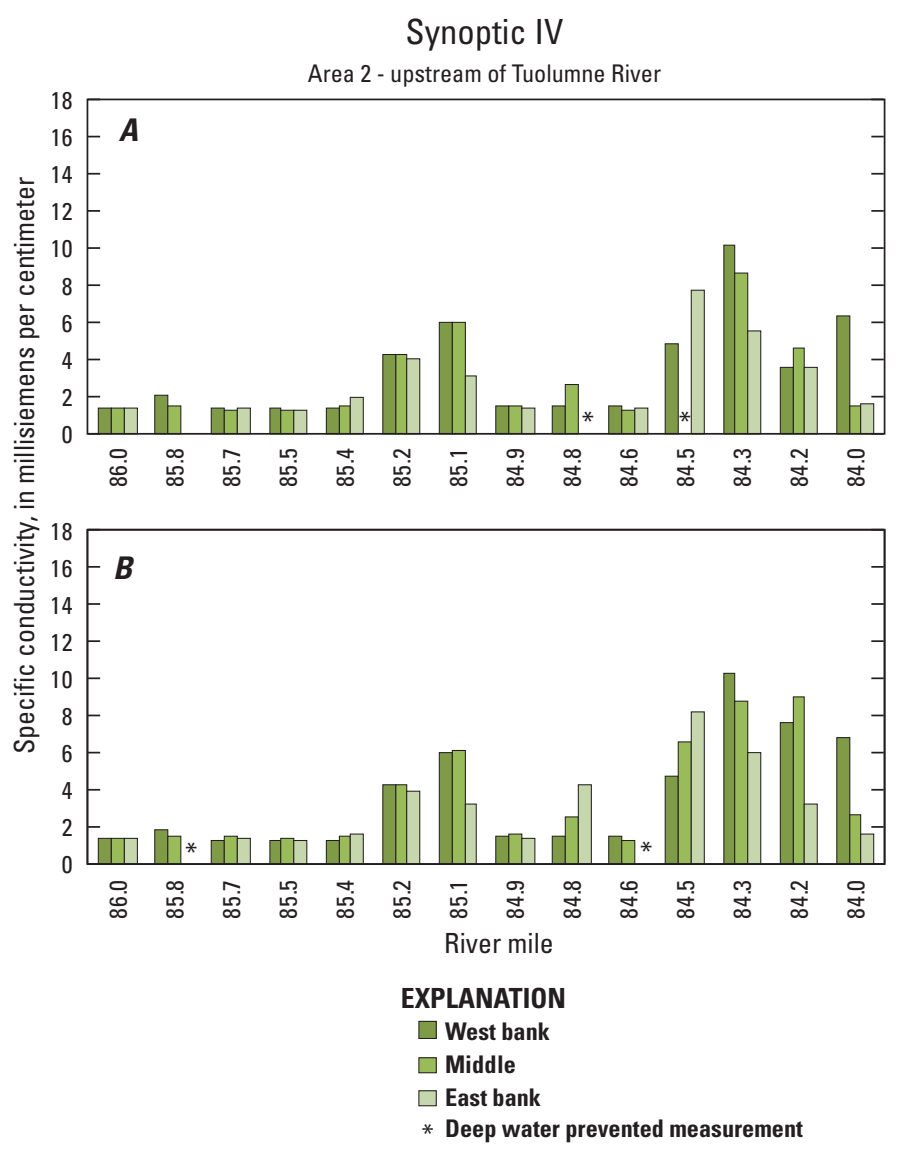

Figure 42. Specific conductivity values measured in area 2 during Synoptic IV, June 2009, at $A$, 1-foot depth and $B$, 3-feet depth. 


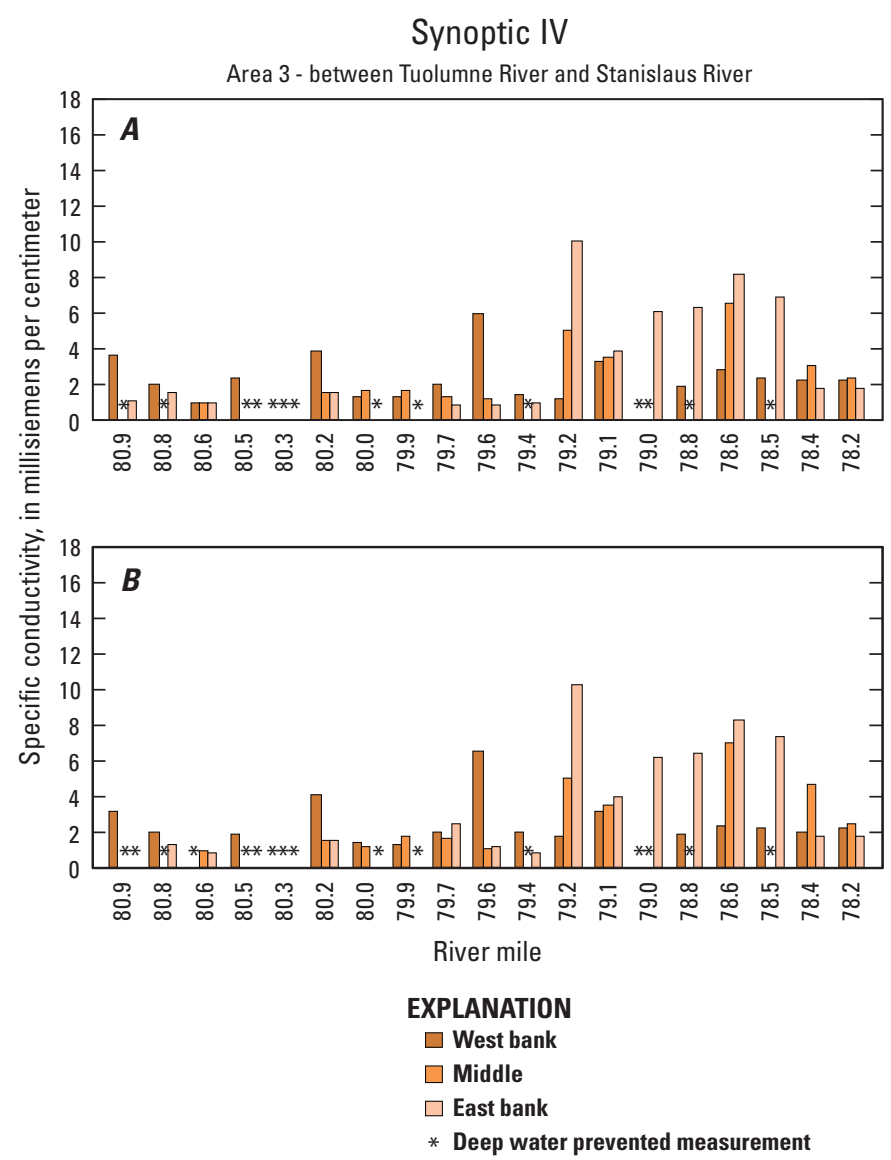

Figure 43. Specific conductivity values measured in area 3 during Synoptic IV, June 2009, at $A, 1$-foot depth and $B$, 3-feet depth.

\section{Water-Quality Results}

\section{Water-Quality Results for Samples from Monitoring Wells}

The bank wells were monitored from September 2006 to December 2008 (20 collection dates), and the in-stream wells were monitored from May 2007 to January 2009 (20 collection dates). High river flows during the 2006 water year prevented installation and monitoring of the in-stream wells until May 2007, a delay of 9 months relative to monitoring of the bank wells. Bank wells were installed at only three of the six well sites (Newman, Crows Landing, and Patterson), whereas in-stream wells were installed at all six well sites. The waterquality data collected from the bank wells and the in-stream wells are presented in appendix 4.

\section{Spatial Trends in Groundwater Quality}

The spatial trends of SC, nitrate, and ammonium from the bank wells and in-stream wells are presented in figure 44 and discussed individually. The box plots for each well represent the 10th percentile (bottom whisker), 25th percentile (bottom of box), median (red dot), 75th percentile (top of box), and 90th percentile (top whisker) calculated using all of the data collected for a specific parameter for that well.

\section{Specific Conductivity}

The median SC value among the 26 monitoring wells was $2.35 \mathrm{mS} / \mathrm{cm}$ (fig. 44A), with a few wells having exceptionally high median values (NE-107.5 was $5.84 \mathrm{mS} / \mathrm{cm}$, and WRD was $7.26 \mathrm{mS} / \mathrm{cm}$ ). In contrast, three wells (NE-14.5, CRS, and PE-9.5) had a lower median SC value $(0.66 \mathrm{mS} / \mathrm{cm})$. These lower SC values were all in the shallowest wells in their locations and could reflect their connection to the river water because their SC values were similar to those of the river $(1.11 \mathrm{mS} / \mathrm{cm} \pm 0.14 \mathrm{mS} / \mathrm{cm}$, tables 9 and 10$)$. There was no consistent trend in SC in the shallow groundwater longitudinally (upstream to downstream) along the monitored river reach. The majority of the wells displayed little temporal variability (fig. 45); however, the two West Stanislaus wells (WRS and WRD) showed more than $2 \mathrm{mS} / \mathrm{cm}$ variability during the monitoring period. The greater variability at the West Stanislaus site could be attributed to the seasonal water dynamics associated with operations of the extensive wetlands located next to the monitoring wells (fig. 15D) or the proximity of this site to the confluence with the Tuolumne River.

\section{Nitrate}

Nitrate concentrations in the monitoring wells ranged from less than detection (less than $0.01 \mathrm{mg} / \mathrm{L}$ as $\mathrm{N}$ ) to approximately $14 \mathrm{mg} / \mathrm{L}$ as $\mathrm{N}$ (fig. 44B, appendix 4). A total of 17 of the 26 monitoring wells showed no detectable nitrate during the monitoring period. The lack of nitrate could be attributed to denitrification, which results in the loss of nitrate to nitrogen gases (dinitrogen, $\mathrm{N}_{2}$, and nitrous oxide, $\mathrm{N}_{2} \mathrm{O}$ ) under anoxic conditions. The highest nitrate concentrations were in the Newman-West 14.5, (NW-14.5, $14 \mathrm{mg} / \mathrm{L}$ as N), Crows Landing in-stream deep well (CRD, $8.6 \mathrm{mg} / \mathrm{L}$ as $\mathrm{N}$ ), and Crows Landing-East 19.5 (CE-19.5, $12 \mathrm{mg} / \mathrm{L}$ as N) wells. Temporal variability was also highest for those wells having the highest nitrate concentrations, as indicated by the sizes of the boxes in figure 44B. Nitrate concentrations were somewhat higher at the upstream locations compared to the downstream locations. One exception to this trend was higher nitrate concentrations at the Vernalis in-stream-shallow well (VRS), which displayed seasonal nitrate spikes (up to $5 \mathrm{mg} / \mathrm{L}$ as $\mathrm{N}$ ) from August to December each year. 
$\boldsymbol{A}$

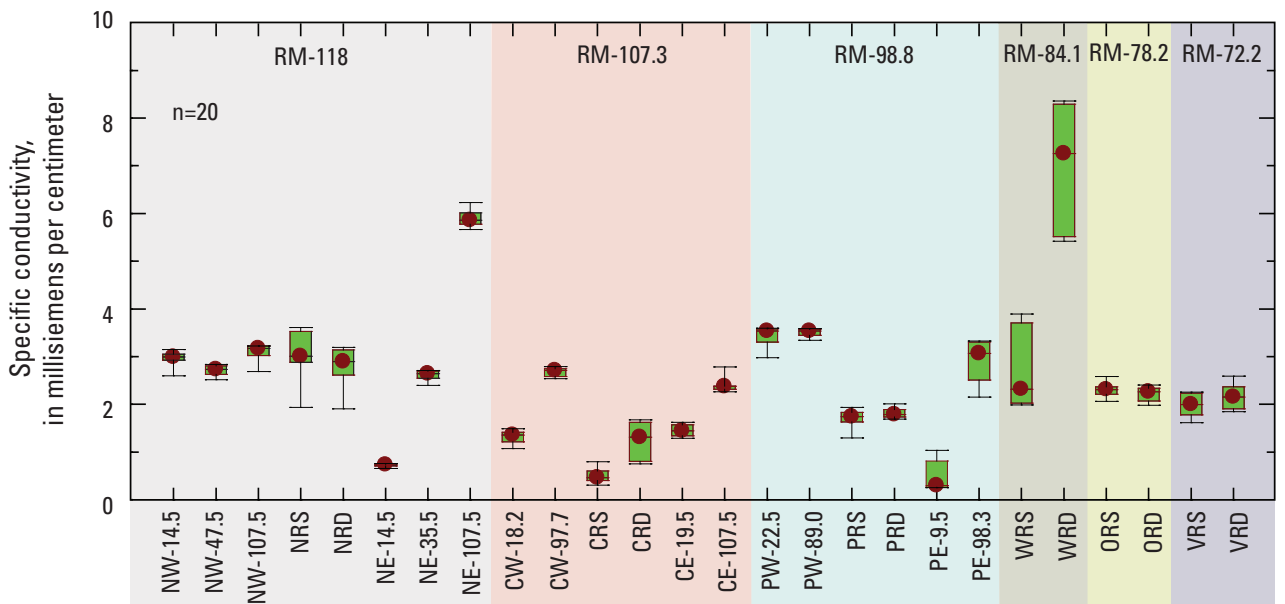

EXPLANATION

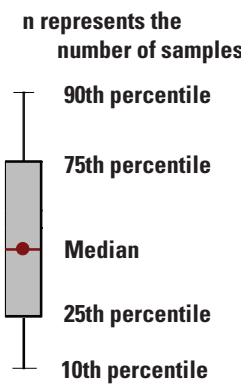

RM River mile

Well name

B

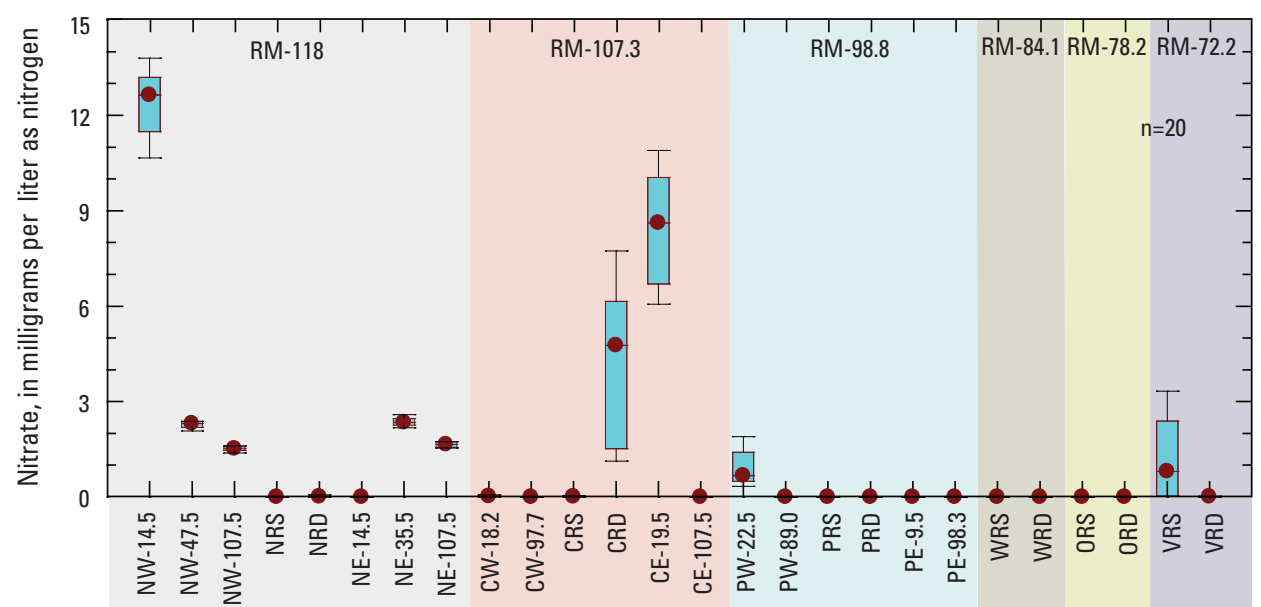

Well name

C

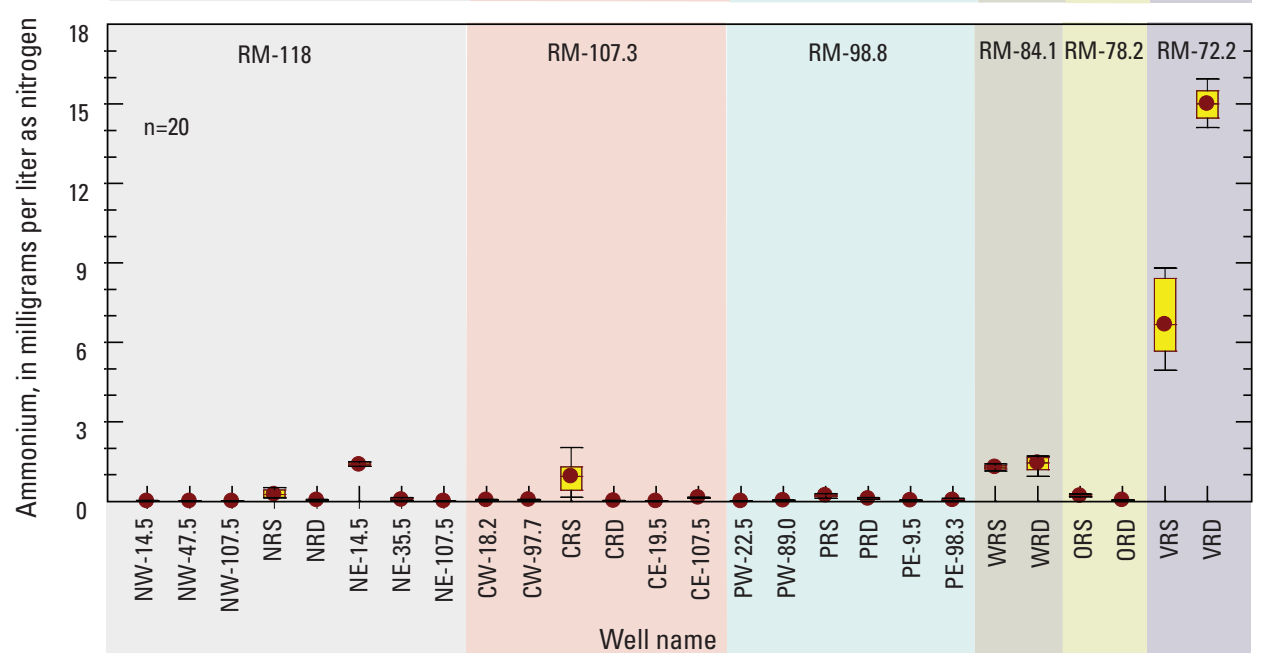

Figure 44. Spatial trends in water-quality samples collected from bank wells and in-stream wells during $2006-08$ for $A$, specific conductivity; $B$, nitrate; and $C$, ammonium. See table 4 for explanation of well identifiers. 

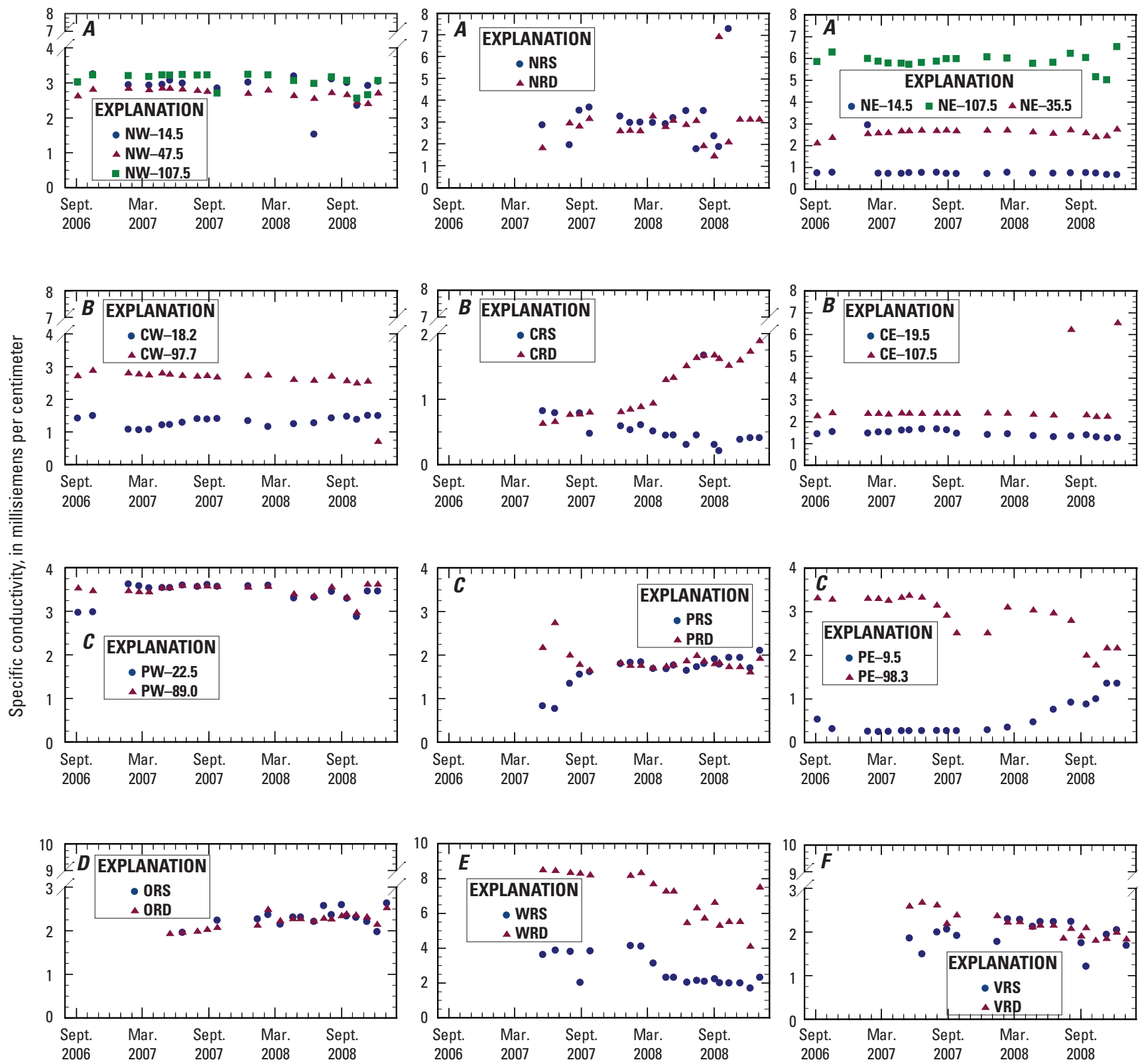

Figure 45. Temporal variability in specific conductivity measured over the study period for the bank well sites $A$, Newman; $B$, Crows Landing; $C$, Patterson, and in-stream wells sites $D$, Orchard Road; $E$, West Stanislaus Road; and $F$, Vernalis. See table 4 for explanation of well identifiers.

\section{Ammonium}

Ammonium concentrations were generally low (less than $2 \mathrm{mg} / \mathrm{L}$ as $\mathrm{N}$; see fig. $44 \mathrm{C}$ ), with the exception of the shallow and deep in-stream wells at Vernalis, where the median concentrations were $6.7 \mathrm{mg} / \mathrm{L}$ as $\mathrm{N}$ in the shallow well (VRS) and $15 \mathrm{mg} / \mathrm{L}$ as $\mathrm{N}$ for the deep well (VRD). Samples from the Vernalis wells were analyzed for selected wastewater constituents by the USGS National Water Quality Laboratory (Zaugg and others, 2007), and the results indicated no evidence of human or livestock constituents (hormones, caffeine, for example) in these samples. These findings, coupled with local land-use data, indicate that the ammonium is not a result of septic systems or animal waste sources in the vicinity. Ammonium is stable under the generally anoxic conditions characteristic of most wells. The median dissolved oxygen concentration for the 26 monitoring wells was 0.32 $\mathrm{mg} / \mathrm{L}$; the median was slightly higher for the VRS and VRD wells at $0.61 \mathrm{mg} / \mathrm{L}$. We hypothesize that in the absence of oxygen, the nitrification process (microbial transformation of ammonium to nitrate) is inhibited because that transformation process is mediated by aerobic bacteria; therefore, ammonium would not be transformed to nitrate, which could be subsequently denitrified (Korom, 1992; Chapelle and others, 1995; Brunet and Garcia-Gil, 1996; Landon and others, 2011). 


\section{Temporal Variability (2-year Comparison)}

\section{Specific Conductance}

There was little temporal variability in SC measured in the bank wells during the monitoring period, with the exception of measurements made from CE-107.5 in August and December 2008 and from PE-9.5 and PE-98.3 (fig. 45). Furthermore, the deeper bank wells had higher SC values than the shallow wells, with the exception of PW-89.0, in which the measured values were very similar between both depths for most of the monitoring period. The SC measured in the in-stream well CRD increased over the monitoring period (May 2007-January 2009) and decreased in the in-stream well WRD from March 2008 to December 2008. The remaining in-stream wells at the Newman and Patterson sites showed no distinct temporal variability or appreciable differences in the SC measured between the deep and shallow wells.

\section{Nitrate}

Nitrate concentrations varied during the monitoring period (fig. 46). Most of the wells showed no distinct temporal variability; however, a few displayed appreciable variability. Of note, the CE-19.5 well showed a decrease in nitrate concentrations from $12 \mathrm{mg} / \mathrm{L}$ as $\mathrm{N}$ in September 2006 to a minimum of around $6 \mathrm{mg} / \mathrm{L}$ as $\mathrm{N}$ from April to October 2007, followed by an increase to $11 \mathrm{mg} / \mathrm{L}$ as $\mathrm{N}$ in December 2008. During this period of increase for CE-19.5, the CRD well also showed a less steady increase from less than $2 \mathrm{mg} / \mathrm{L}$ to around 6-8 mg/L. The CRD well also showed a longterm increase from nearly $1 \mathrm{mg} / \mathrm{L}$ as $\mathrm{N}$ in summer 2007 to a maximum of 6-8 mg/L as N from June to December 2008. In contrast, PW 22.5 showed a short-term spike (greater than $2.5 \mathrm{mg} / \mathrm{L}$ as $\mathrm{N}$ ) in nitrate concentrations at the onset of the study (March 2007) followed by a decrease to relatively consistent concentrations between 0.5 to $1.0 \mathrm{mg} / \mathrm{L}$ as $\mathrm{N}$ for the remainder of the study. Neither the Crows Landing nor Patterson nitrate variability was consistent with seasonal patterns associated with summer irrigation or winter rainfall. The only well showing relatively consistent seasonal patterns was the in-stream VRS well, which showed spikes in nitrate concentrations (maximum concentration of $5.1 \mathrm{mg} / \mathrm{L}$ as $\mathrm{N}$ ) from September to December of both years. This pattern might reflect the summer irrigation season with a lag period or, possibly, dilution by winter rainfall.

\section{Ammonium}

Ammonium concentrations in most of the monitoring wells were very low (median concentration $0.02 \mathrm{mg} / \mathrm{L}$ as $\mathrm{N}$ ), and most wells exhibited measurement variability fluctuations rather than distinct temporal patterns during the monitoring period. Notable exceptions to this were the in-stream wells at Patterson, Crows Landing, and Vernalis sites (fig. 47). At the Patterson site, the ammonium concentrations in the deep in-stream wells (PRD) decreased over time, while the shallow in-stream well (PRS) increased (fig. 47C). There was a distinct pattern of decreasing ammonium concentrations (2.3 to less than $0.1 \mathrm{mg} / \mathrm{L}$ as $\mathrm{N}$ ) in the Crows Landing in-stream shallow well (CRS) over the period of record. In addition, there was a seasonal pattern of decreasing ammonium in the VRS monitoring well (fig. 46F) that was inversely related to the nitrate concentrations in this same well (fig. 47F ). Thus, the seasonal pattern in both ammonium (decreasing) and nitrate (increasing) in the Vernalis in-stream shallow well could reflect the oxidation-reduction (redox) status of the groundwater with seasonal transformation of ammonium to nitrate (nitrification) controlling this pattern.

\section{Dissolved Organic Carbon}

DOC concentrations in water from monitoring wells ranged from less than detection to a maximum value of $11 \mathrm{mg} / \mathrm{L}$ (fig. 48). The MDL for DOC was $0.3 \mathrm{mg} / \mathrm{L}$ for samples analyzed from September 2006-June 2008 and $0.1 \mathrm{mg} / \mathrm{L}$ for samples analyzed from July 2008-January 2009. In general, most DOC concentrations fell within the $1-4 \mathrm{mg} / \mathrm{L}$ range. DOC concentrations tended to be higher in the shallow wells and lower in the deeper wells, with a few exceptions where concentrations were nearly equal with depth, such as the Crows Landing East (CE-19.5 and CE-107.5) bank well sites and Orchard Road (ORS and ORD) in-stream well sites. The lower DOC concentrations with depth indicated that the presumably older water at depth has experienced greater bacterial consumption of DOC as a result of its greater residence time (Jurgens and others, 2008; Chapelle and others, 2012).

Most wells had relatively consistent temporal patterns in DOC concentrations. The in-stream wells at the Newman (NRS and NRD), Crows Landing (CRS), and Vernalis (VRS and VRD) sites, however, displayed considerable variability over the monitoring period. During the last year of the study, the Newman (NRS and NRD) and Vernalis (VRS and VRD) in-stream wells appeared to show a decrease in DOC concentrations, from 8.7 to less than $0.1 \mathrm{mg} / \mathrm{L}$ and from 5.2 to $1.1 \mathrm{mg} / \mathrm{L}$, respectively. The CRS in-stream well had the highest DOC concentration in June 2007 (11.1 mg/L); DOC concentrations ranged from 1.8 to $6.5 \mathrm{mg} / \mathrm{L}$ for the remainder of the monitoring period. In general, DOC concentrations in the shallower wells had greater temporal variability than concentrations in the deeper wells because they could be more influenced by local land-use activities (for example, irrigation and seasonal rainfall; Findlay and others, 2001). 

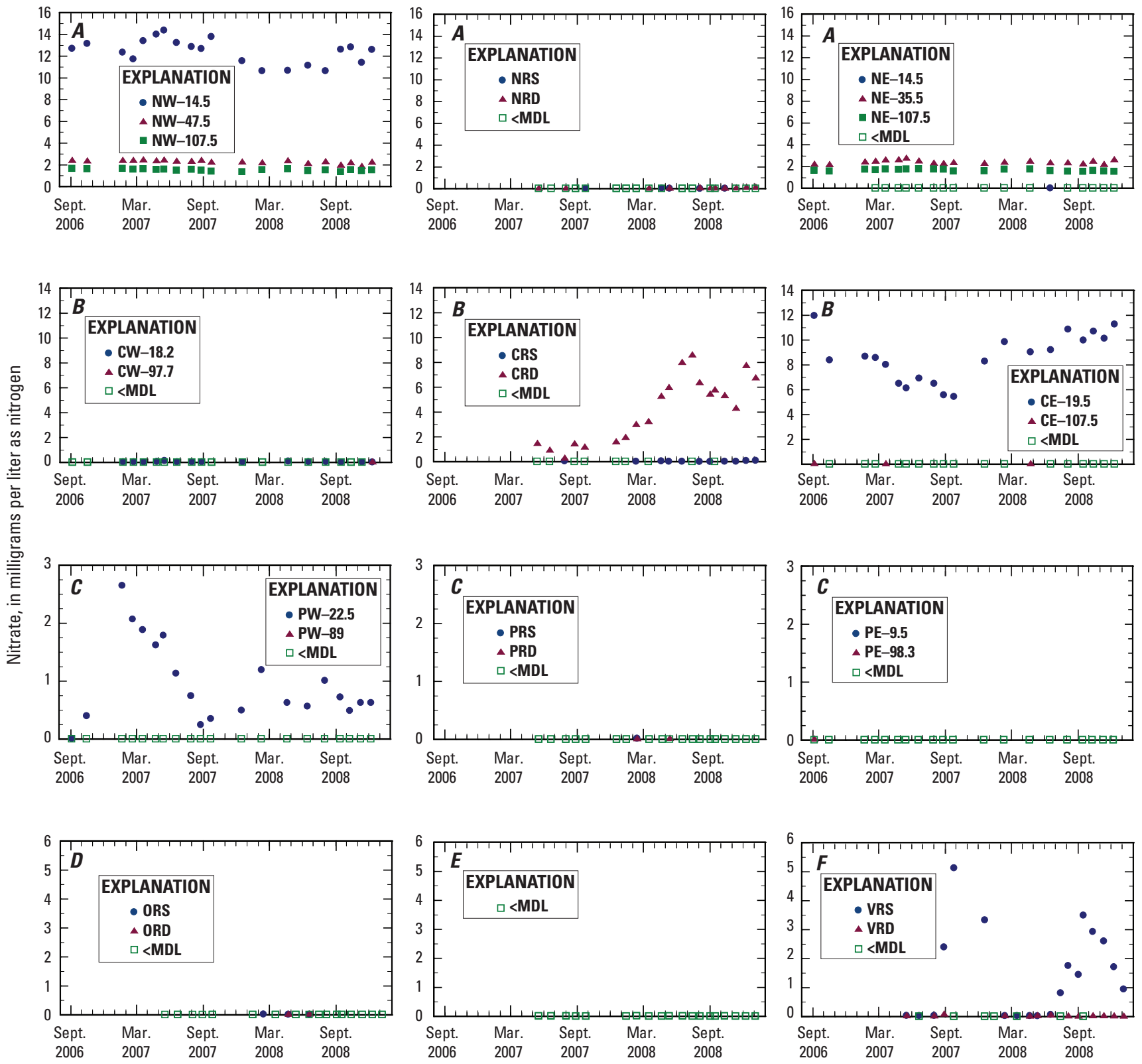

Figure 46. Temporal variability in nitrate concentrations over the monitoring period for the bank well sites at $A$, Newman; $B$, Crows Landing; $C$, Patterson, and in-stream wells sites; $D$, Orchard Road; $E$, West Stanislaus Road; and $F$, Vernalis. See table 4 for explanation of well identifiers. 

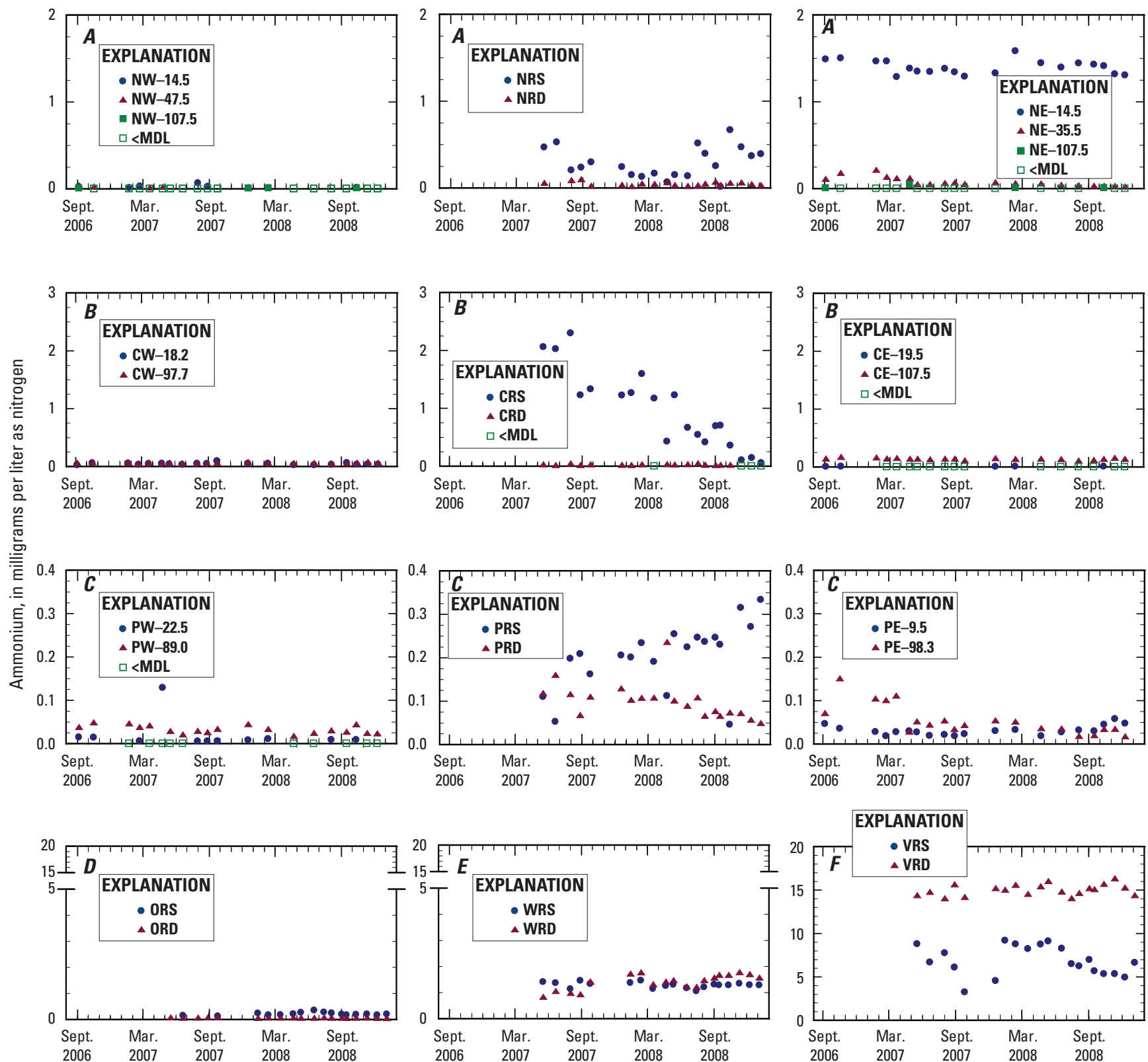

EXPLANATION
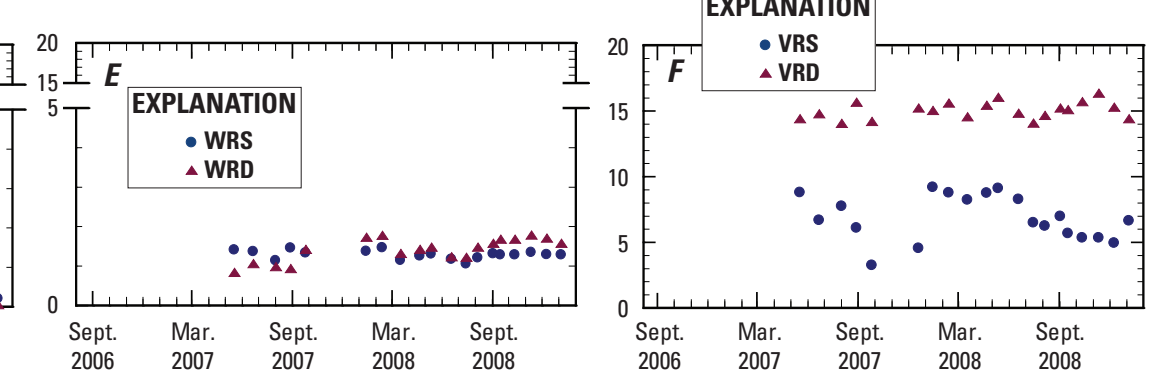

Figure 47. Temporal variability in ammonium concentrations over the monitoring period for the bank well sites at $A$, Newman; $B$, Crows Landing; $C$, Patterson, and in-stream wells; $D$, Orchard Road; $E$, West Stanislaus Road; and $F$, Vernalis. See table 4 for explanation of well identifiers. 

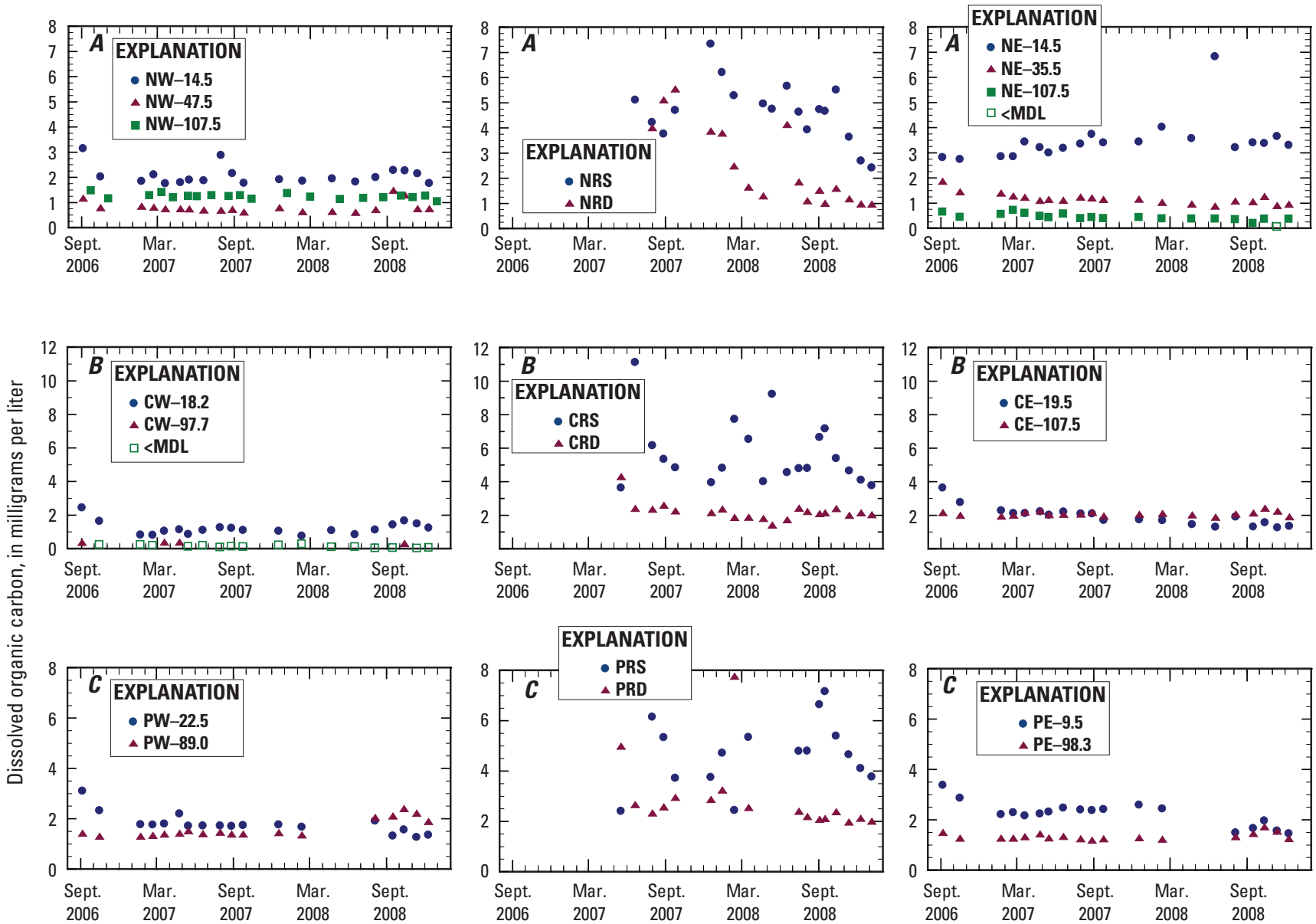

EXPLANATION
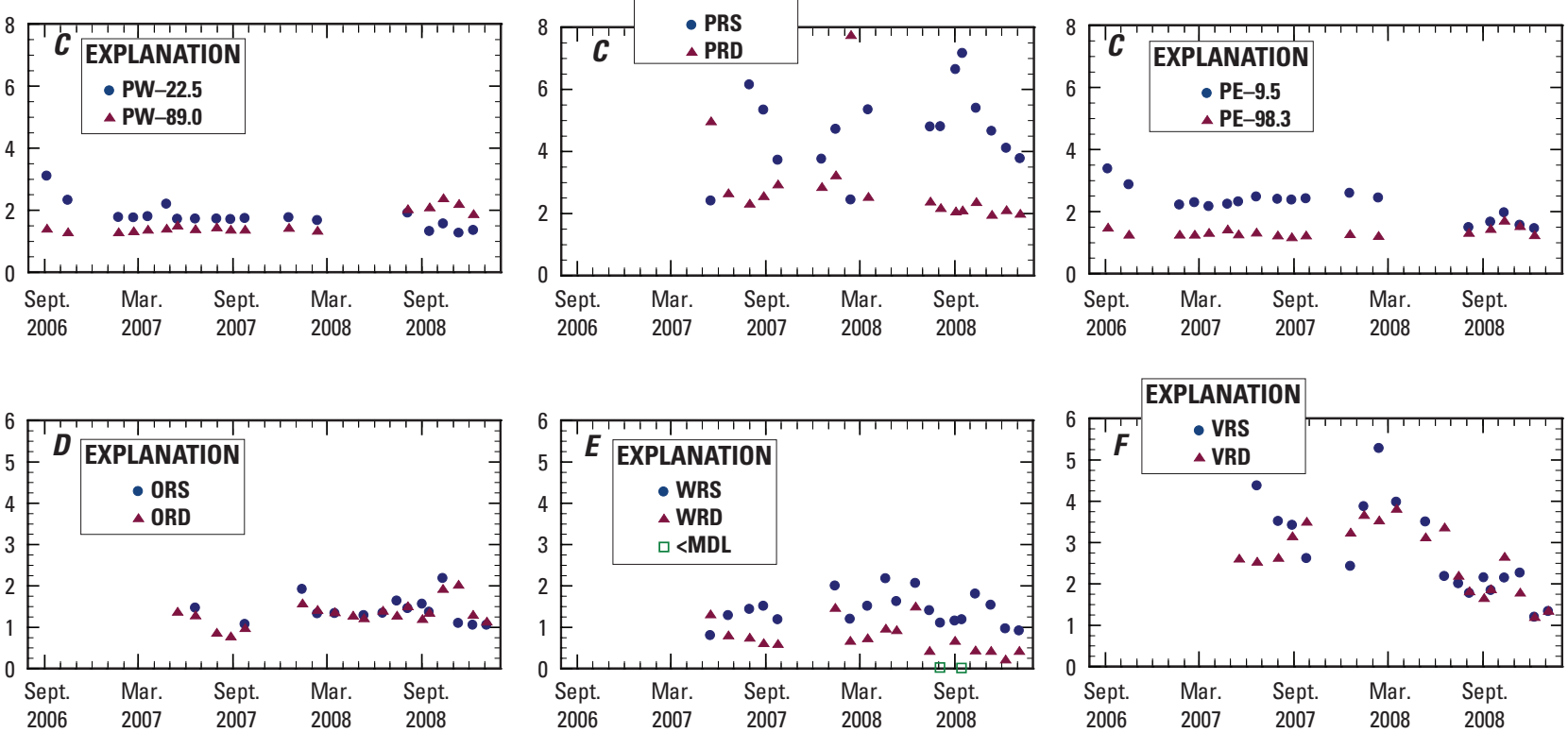

Figure 48. Temporal variability in dissolved organic carbon concentrations over the monitoring period for the bank well sites at $A$, Newman; $B$, Crows Landing; $C$, Patterson, and in-stream wells sites; $D$, Orchard Road; $E$, West Stanislaus Road; and $F$, Vernalis. See table 4 for explanation of well identifiers.

\section{Comparison to Historic 1988 Data}

This 20-year comparison (1988 to about 2008) was based on wells at only three sites (Newman, Crows Landing, and Patterson), so this observation is not to be extrapolated to the larger study area without additional comparative data. Nitrate and SC were sampled once following installation of the 14 bank wells in 1988. Thus, we are able to compare differences in these constituents over an 18- to 20-year period. Although there was a lack of temporal sampling during the 1988 study, the median nitrate and SC values measured during the later monitoring period were similar to those determined 20 years ago, with a few notable exceptions (fig. 49). 

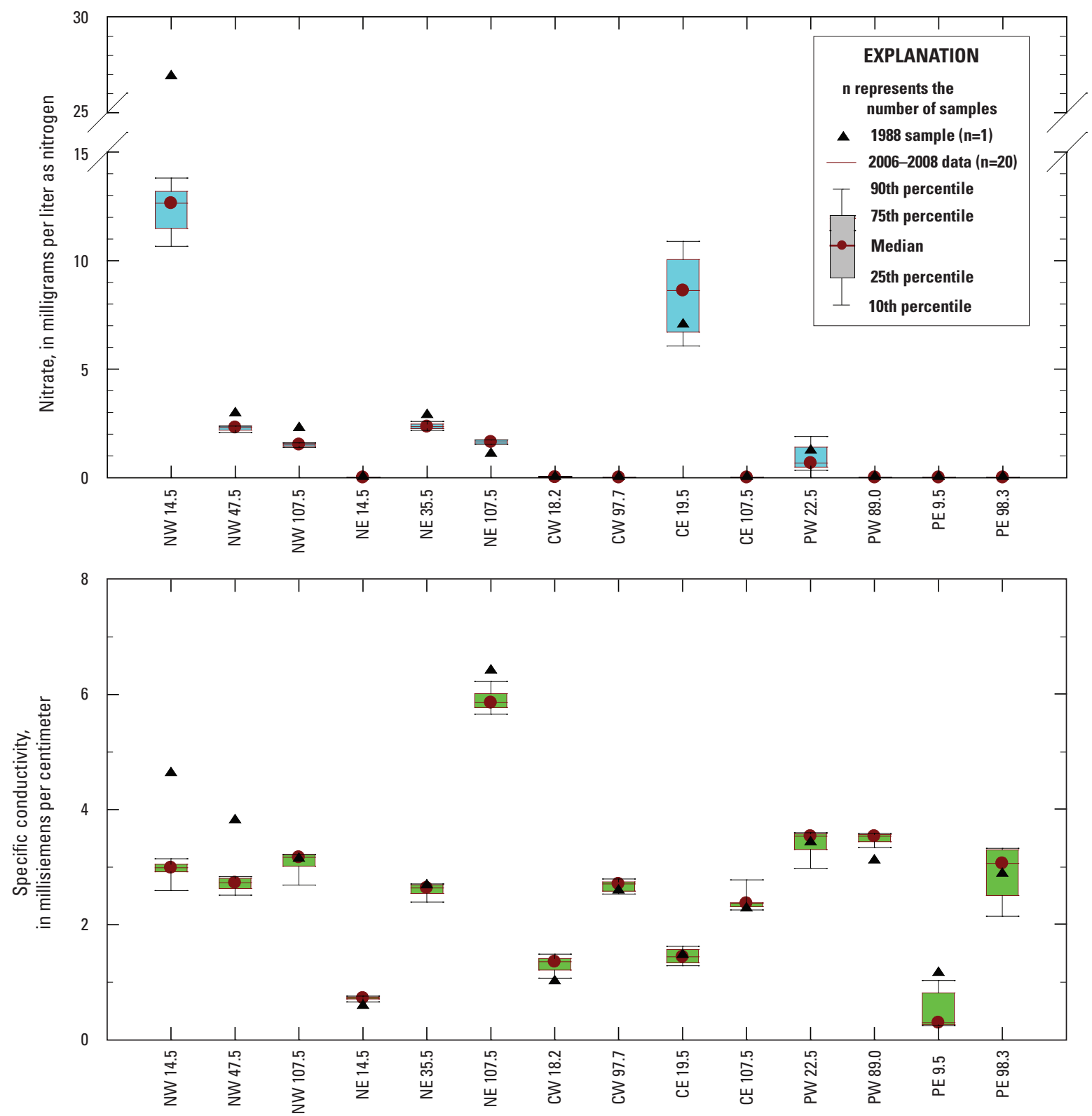

Figure 49. Comparison of the 2006-08 and 1988 data for bank wells sampled during both study periods for $A$, nitrate concentrations and $B$, specific conductivity. See table 4 for explanation of well identifiers.

During the 20-year period (1988 to about 2008), there was a large decrease in nitrate concentrations at the NW-14.5 well; nitrate decreased from approximately 27 to $11-14 \mathrm{mg} / \mathrm{L}$ as N. Similarly, SC values were similar over the 20-year period, with the exception of the NW-14.5 and NW-47.5 wells that had somewhat higher SC values (higher by $1-2 \mathrm{mS} / \mathrm{cm}$ ) during the 1988 sampling period (fig. 49). Thus, we concluded that, with respect to nitrate and SC values, there had been little change in groundwater quality over the 20 years. The lack of long-term variability (20 years) was consistent with the general lack of temporal variability that we observed among the 20 sampling events over the approximately 2-year period of the later monitoring period (figs. 45-46). 


\section{Water-Quality Results for the Streambed Synoptic Samples}

Four streambed synoptic studies were carried out along the 59-mi river reach (SJR confluence with Salt Slough to Vernalis) during the study period to provide broad spatial coverage for the quality of groundwater interacting with the SJR. The water-quality data collected from each of these synoptics are presented in appendixes 5-8. River water, shallow groundwater (1-ft depth), and deeper groundwater (3and 6-ft depths) were examined along cross-sectional transects with horizontal positions at 20 percent [east], 50 percent [midpoint] and 80 percent [west] of the total stream width during streambed Synoptic II and IV; at 20 percent [east] and 80 percent [west] of the total stream width during Synoptic I; and at 50 percent of the total stream with during Synoptic III. Although this method allowed for better spatial coverage than the six monitoring-well sites, it did not provide the temporal coverage given by monitoring well sites. This approach, coupled with the longitudinal profile survey data, allowed an expansion of our understanding of the results from the six monitoring sites to the entire 59-mi study reach. Results for SC, nitrate, ammonium, and DOC are presented separately.

\section{Specific Conductivity}

The SC of groundwater collected during the synoptic surveys samples ranged from $0.42 \mathrm{mS} / \mathrm{cm}$ to $17 \mathrm{mS} / \mathrm{cm}$ (fig. 50). Groundwater SC values were higher at upstream sites (river miles 118 to 128) and also at two downstream locations, near river miles 84 and 78, compared to other sites. By comparison, the SC of surface-water samples from the SJR decreased from a median of $1.07 \mathrm{mS} / \mathrm{cm}$ for the upstream Newman site (river mile 118) to a median of $0.77 \mathrm{mS} / \mathrm{cm}$ at the downstream Vernalis site (river mile 72) for Synoptics IIII (figs. 20-22). The decrease in SC values at downstream surface-water sites were likely a result of dilution by lower SC waters from the three east-side tributaries, Merced (DWR CDEC MST), Tuolumne (USGS 11290000 NWISweb), and Stanislaus (USGS 11303000 NWISWeb).
The two primary groundwater sources in the study area are low-salinity waters originating from sediments of the Sierra Nevada and high-salinity waters originating from the Coast Range sediments (Letey and others, 2002). The Coast Range sediments are naturally saline owing to their origin as marine sediments containing appreciable fossil salts and salts originating from oxidation of sulfides (Letey and others, 2002; Schoups and others, 2005). It is hypothesized that the groundwater salinity concentrations are regulated to a first approximation by the mixing ratio of east-side (Sierra Nevada) compared to west-side (Coast Ranges) groundwater (Letey and others, 2002). West-side groundwater at the 3- to 6-ft depth had a slightly higher average SC $(4.96 \mathrm{mS} / \mathrm{cm})$ than east-side groundwater $(4.34 \mathrm{mS} / \mathrm{cm})$ at the 3 - to 6 -ft depth, which could partially reflect differences in water sources entering the river.

The SC measured at the 1-ft depth is compared to the SC measured at deeper depths (3-6 ft) for the same location (that is, shallow compared to deep pairs) in figure 51 for the four synoptics; the one-to-one line is included for comparison. Although many of the points lie near the one-to-one line, more points lie above the line than below it, indicating a tendency toward higher SC values for the deeper samples compared to the shallower samples. The median SC value measured at the 3-6-ft depth during the four synoptics was slightly higher $(2.72 \mathrm{mS} / \mathrm{cm})$ than the median SC value measured at the $1-\mathrm{ft}$ depth $(2.32 \mathrm{mS} / \mathrm{cm})$, which could be a result of some mixing of surface water at shallow depths (less than1-ft depth) in the streambed. The overall consistency of the SC values with the one-to-one line for the majority of the samples measured (sample number was 310) indicated that mixing of the shallow groundwater (1-ft depth) with overlying surface waters that had much lower SC values was minimal, however. This overall observation is consistent with a predominately upward groundwater gradient over the 59-mi study reach (groundwater discharge to river). The majority of the points lying above the one-to-one line measured during Synoptic IV (fig. 51D) were primarily from SC values measured between Salt Slough and Mud Slough (river miles 129 to 122) near the highly-saline tile drainage in the nearby Grasslands Drainage Area. 
A
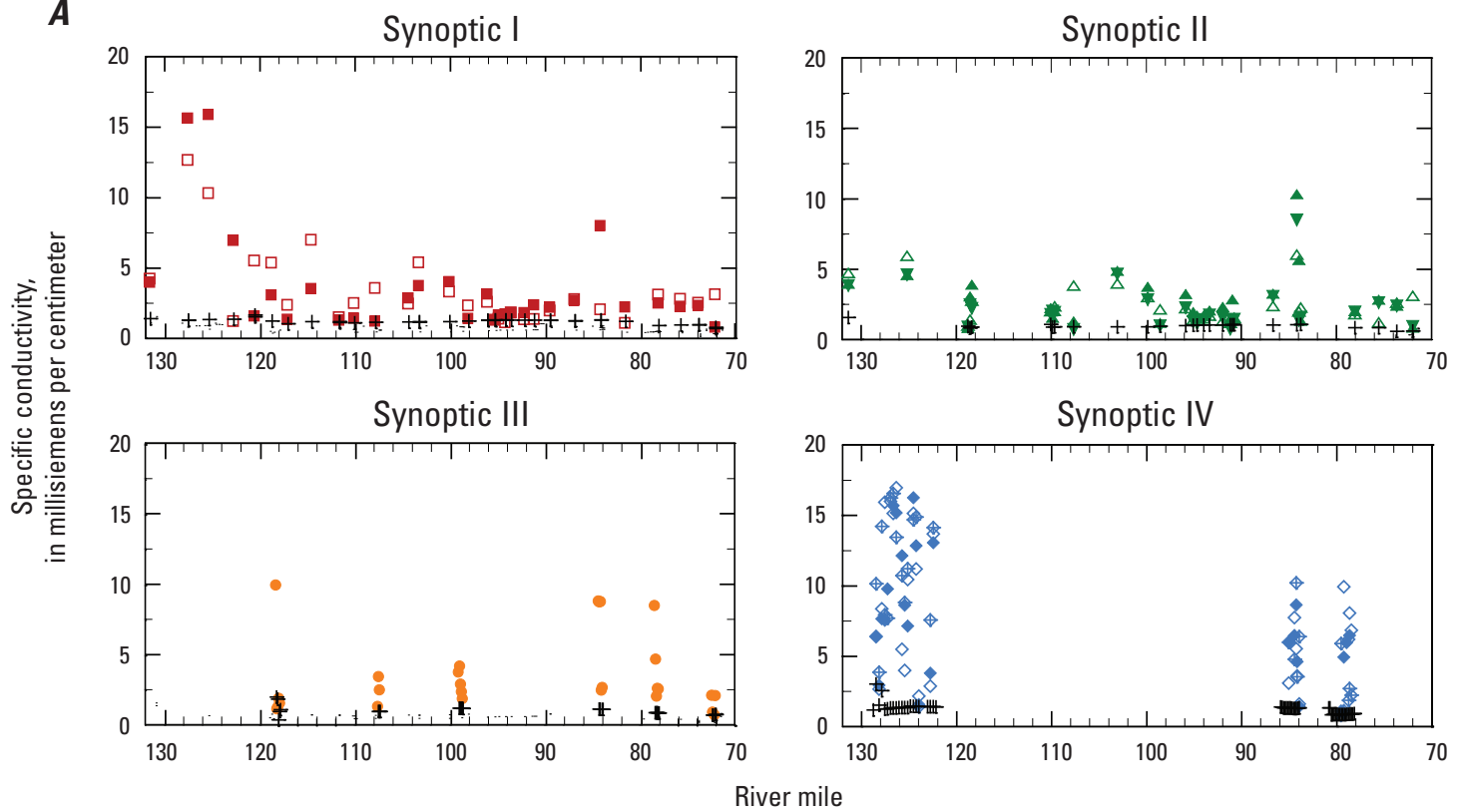

B

Synoptic I
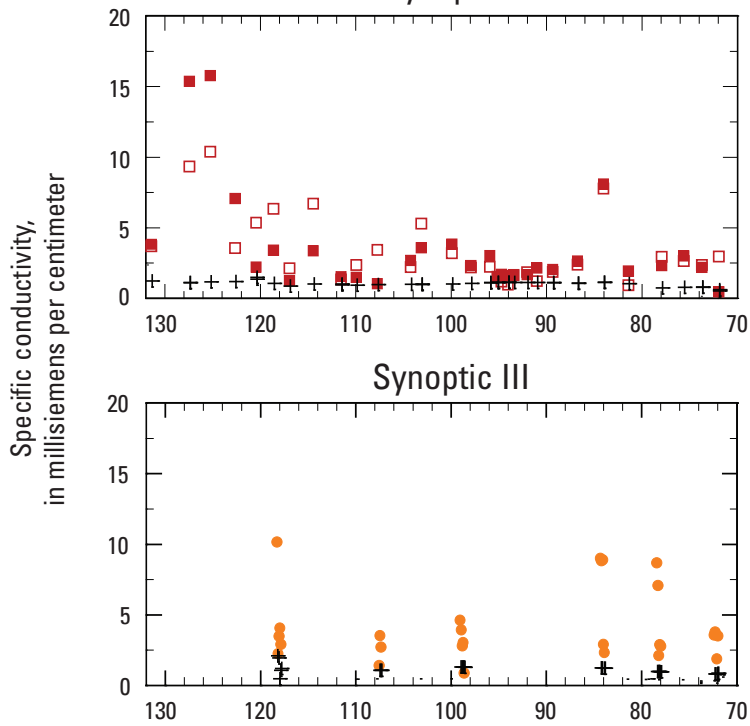

Synoptic II

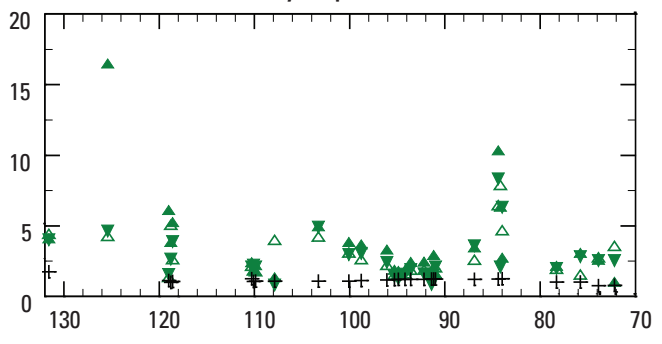

Synoptic IV

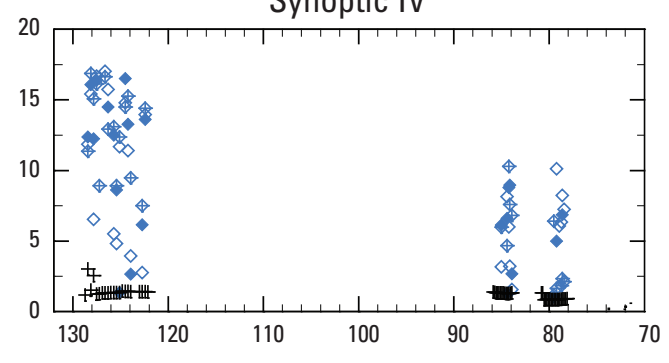

River mile

EXPLANATION

+ San Joaquin River SC

Synoptic I

口 SYN I- $20 \%$

- SYNI- $80 \%$
Synoptic II

$\triangle \quad$ SYN II $-20 \%$

> SYN II - $50 \%$

- SYN II - $80 \%$
Synoptic III

- SYN III- $50 \%$

Synoptic IV

$\diamond \quad$ SYN IV $-20 \%$
$\quad$ SYN IV $-50 \%$
$\diamond \quad$ SYN IV $-80 \%$

Figure 50. Measured specific conductivity (SC) in groundwater below the streambed of the San Joaquin River, at each transect for Synoptics (SYN) I-IV, in $A$, shallow depths (1 foot) and $B$, deep depths (3-6 feet). For each synoptic, the location of the measurements for each transect was selected as a percentage of the total transect distance: 20 percent (\%) was considered the east bank, 50 percent was considered the midpoint, and 80 percent was considered the west bank. 


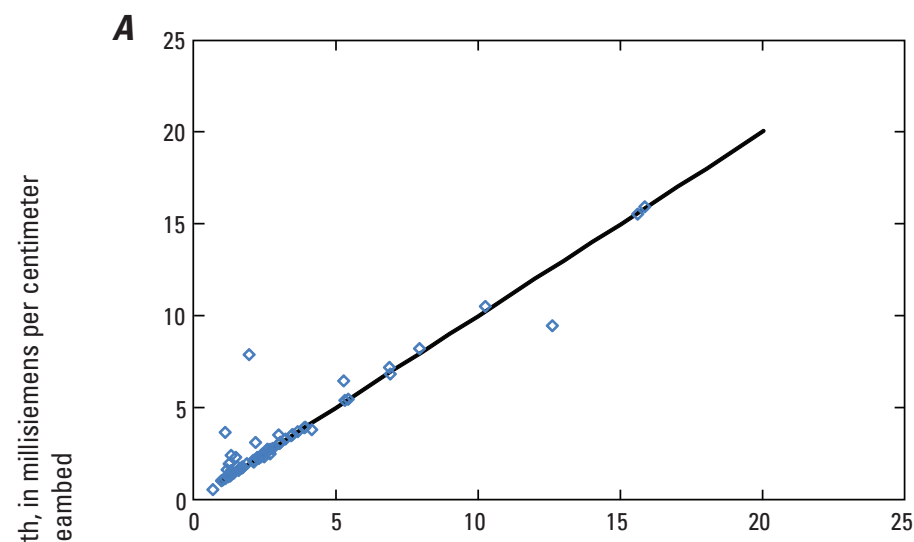

B

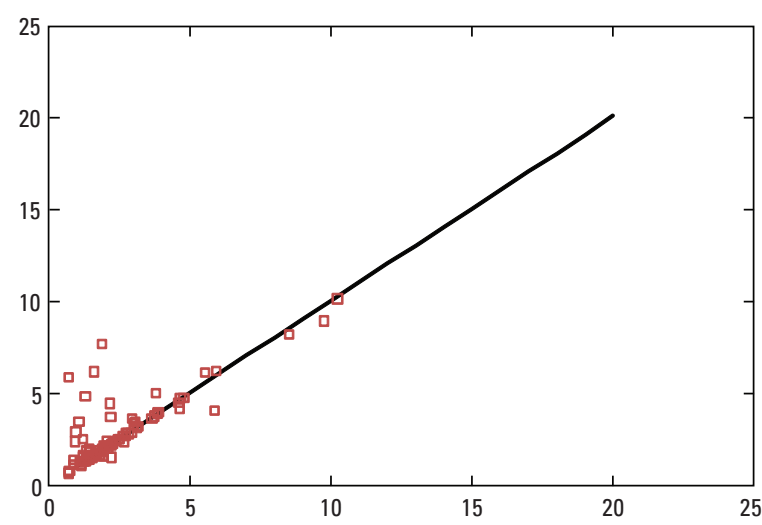

C

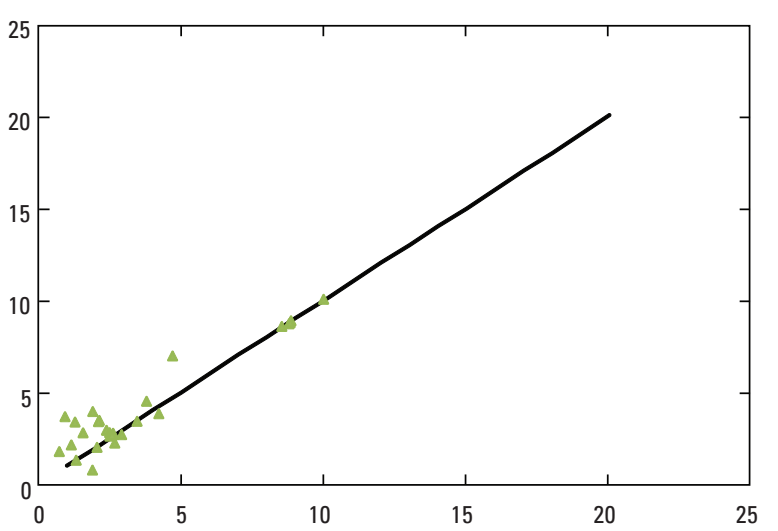

D

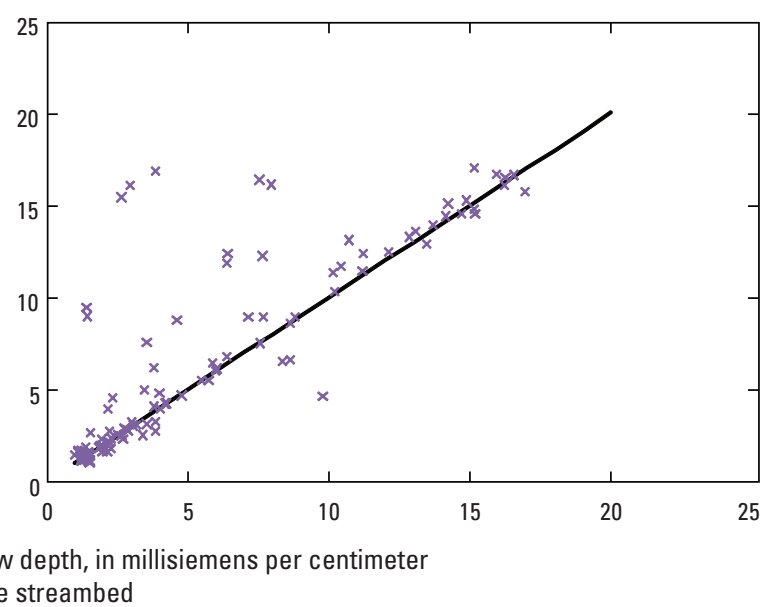

1 feet below the streambed

\section{EXPLANATION}

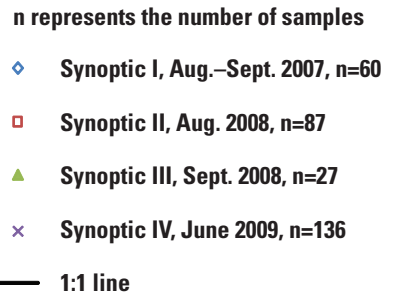

Figure 51. Comparison of specific conductivity measured at shallow depth (1 foot) versus deep depths (3-6 feet) in groundwater below the streambed of the San Joaquin River during $A$, Synoptic I; $B$, Synoptic II; $C$, Synoptic III; and $D$, Synoptic IV.

\section{Nitrate}

Nitrate concentrations measured in shallow groundwater during the streambed synoptics were low for most of the samples (fig. 52). Only 7 of the 113 cross-sectional transects had nitrate concentrations greater than $1 \mathrm{mg} / \mathrm{L}$ as $\mathrm{N}$. There were two sites (river miles 110 and 96) where nitrate concentrations in shallow groundwater were greater than $10 \mathrm{mg} / \mathrm{L}$ as $\mathrm{N}$, the USEPA maximum contaminant level (MCL) for nitrate. Surface waters in the SJR tended to have nitrate concentrations in the $1-4 \mathrm{mg} / \mathrm{L}$ range.

We had initially expected that nitrate concentrations would be high in groundwater measured below the SJR streambed because of the numerous groundwater wells in the San Joaquin Valley that have nitrate concentrations above the USEPA MCL of $10 \mathrm{mg} / \mathrm{L}$ as $\mathrm{N}$. The lack of nitrate in most samples can be explained by the redox (oxidationreduction) conditions of the groundwater. The groundwater at most locations had dissolved oxygen concentrations below $2.0 \mathrm{mg} / \mathrm{L}$; median dissolved oxygen measured during Synoptics I-IV at the 1-ft depth and 3-6-ft depth were 1.82 and $1.98 \mathrm{mg} / \mathrm{L}$, respectively. In the absence of oxygen, nitrate can be used as a terminal electron acceptor during bacterial respiration, and $\mathrm{NO}_{3}$ can be reduced to the gases $\mathrm{N}_{2}, \mathrm{~N}_{2} \mathrm{O}$, or nitric oxide (NO). Another study of SJR sediments confirmed appreciable denitrification potential, which supports the 

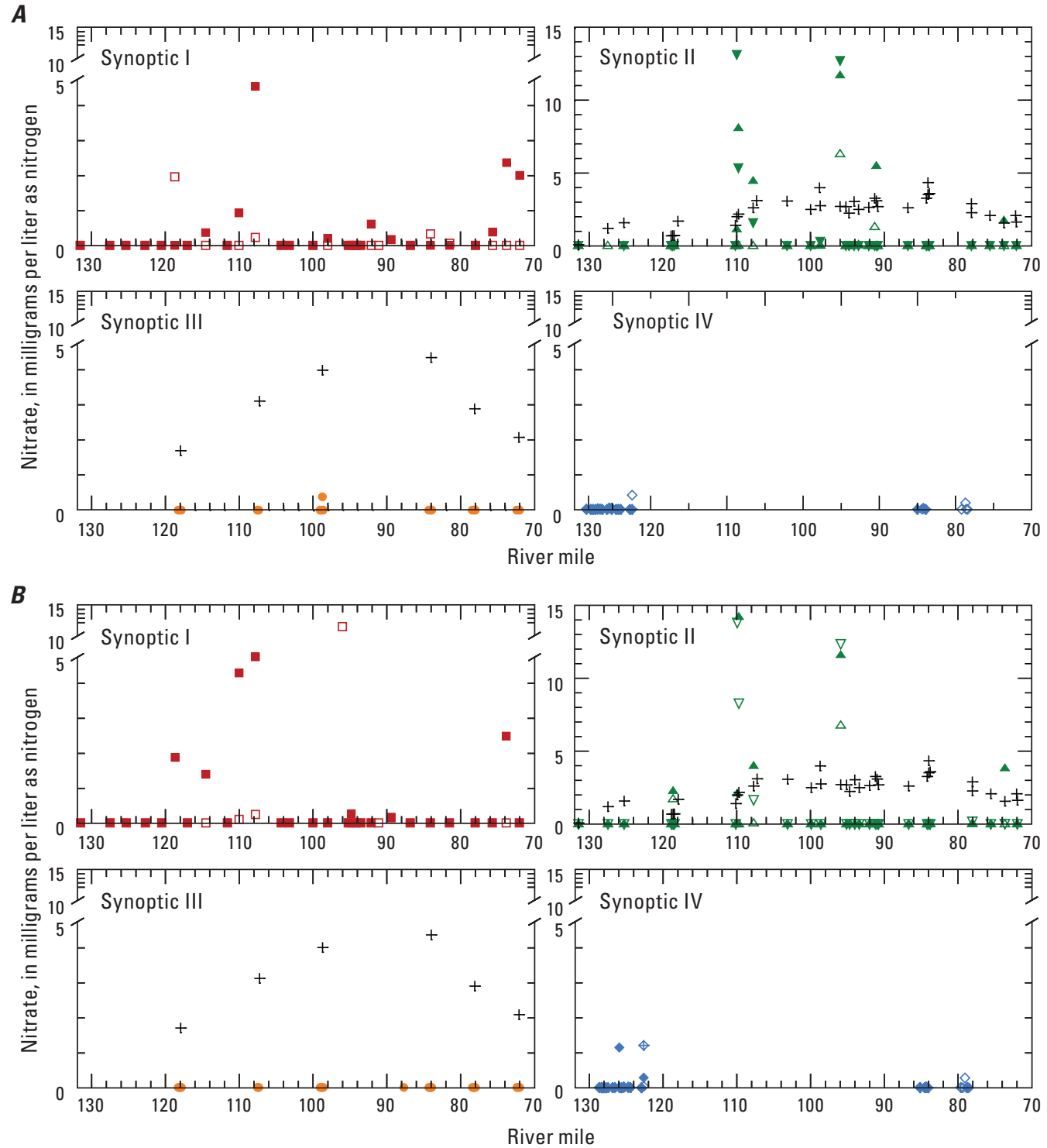

EXPLANATION

+ San Joaquin River nitrate

\begin{tabular}{|c|c|c|c|c|c|c|}
\hline SYN I - 20\% & $\Delta$ & SYN II - 20\% & - & SYN III - 50\% & $\diamond$ & SYN IV - 20\% \\
\hline SYN I - 80\% & $\mathbf{v}$ & SYN II - 50\% & & & $\bullet$ & SYN IV - 50\% \\
\hline & & SYN II - 80\% & & & $\leftrightarrow$ & SYN IV - $\mathbf{8 0 \%}$ \\
\hline
\end{tabular}

Figure 52. Measured detections of nitrate concentrations in groundwater below the streambed of the San Joaquin River at each transect for Synoptics I-IV for $A$, shallow depth (1 foot) and $B$, deep depth (3-6 feet). For each synoptic, the location of the measurements at each transect was selected as a percentage of the total transect distance: 20 percent (\%) was considered the east bank, 50 percent was considered the midpoint, and 80 percent was considered the west bank.

denitrification mechanism for nitrate removal (Zhang and Dahlgren, 2009). In addition, analysis of selected groundwater samples for $\mathrm{N}_{2}$ and argon (Ar) gas concentrations indicated the presence of excess $\mathrm{N}_{2}$ gas relative to the inert Ar gas, which is consistent with denitrification converting $\mathrm{NO}_{3}$ to $\mathrm{N}_{2}$ during groundwater transport (Zhang and Dahlgren, 2009). Thus, we concluded that water moving through a zone of lower oxygen (less than $2 \mathrm{mg} / \mathrm{L}$ ) in the streambed of the SJR could limit the amount of nitrate contributions from the regional groundwater. 
A comparison of dissolved oxygen, nitrate, and ammonium concentrations measured during Synoptics I and II (fig. 53 and 54, respectively) indicated that, in general, nitrate concentrations were below $1 \mathrm{mg} / \mathrm{L}$, or less than detection limits, with a few notable exceptions. Measured nitrate concentrations were higher at river miles 118.7, 110.0, 107.8, 96.0, 91.1, 73.8, and 72.0 during Synoptic I (fig. 53) and higher at river miles 109.8, 107.8, 96.0, 91.1, and 73.8 during Synoptic II (fig. 54). We cannot explain with certainty these exceptions, except that (1) redox processes could be

Synoptic I (August-September 2007)
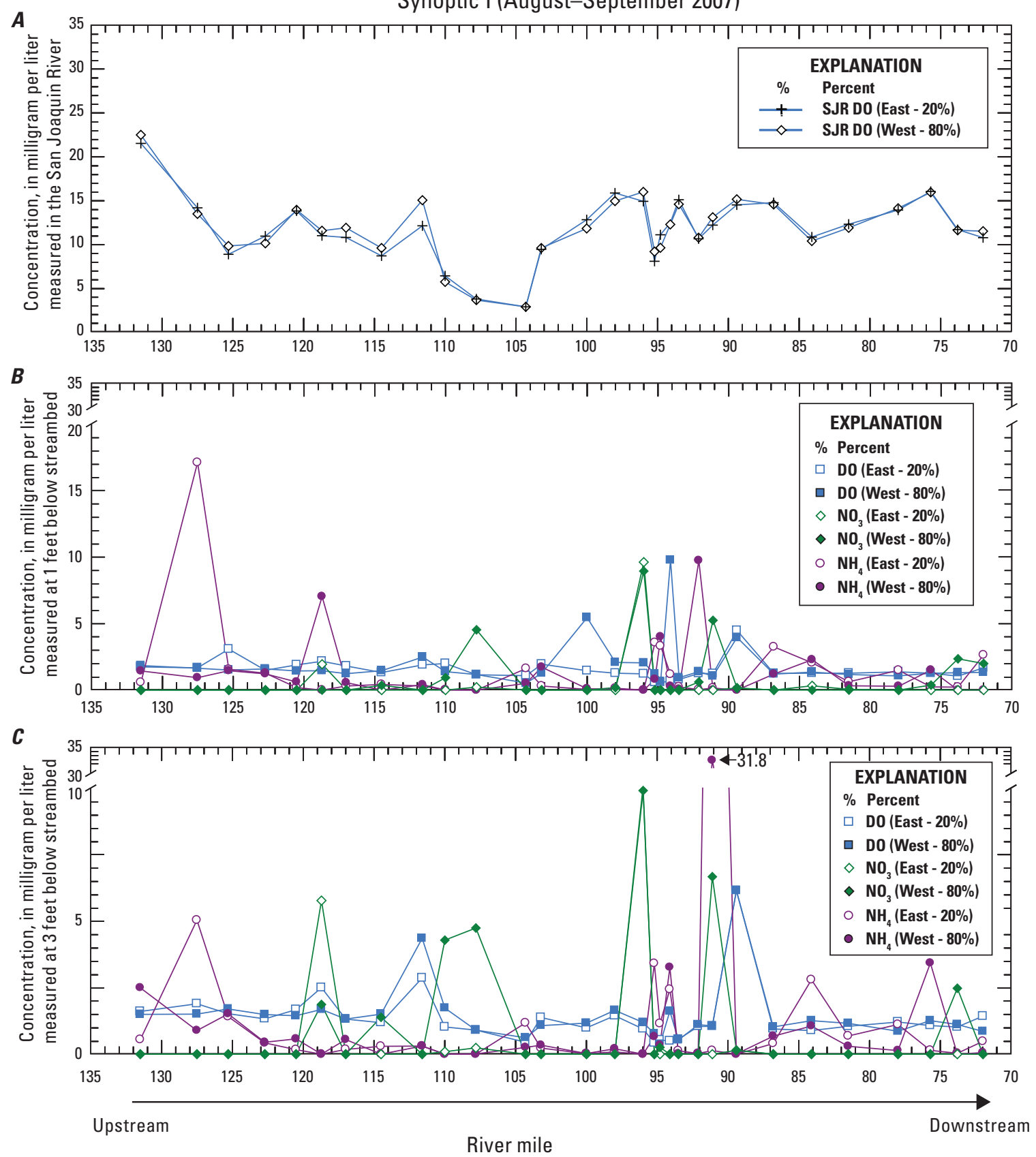

Figure 53. Comparison of dissolved oxygen (DO), nitrate $\left(\mathrm{NO}_{3}\right)$, and ammonium $\left(\mathrm{NH}_{4}\right)$ concentrations measured during Synoptic I in $A$, the San Joaquin River; $B, 1$ foot below the streambed; and $C, 3$ feet below the streambed. 
happening at smaller scales within the streambed than were measurable with the methods used in this study or that (2) the sample collection with the temporary drive-point piezometer resulted in pulling in water surrounding the intended depth interval, which was in a different redox state. The presence of measurable nitrate in about 5 percent of the groundwater samples requires further investigation to determine why these localized areas of higher nitrate exist in areas where nitrate concentrations generally are low or below detection limits.
$\boldsymbol{A}$
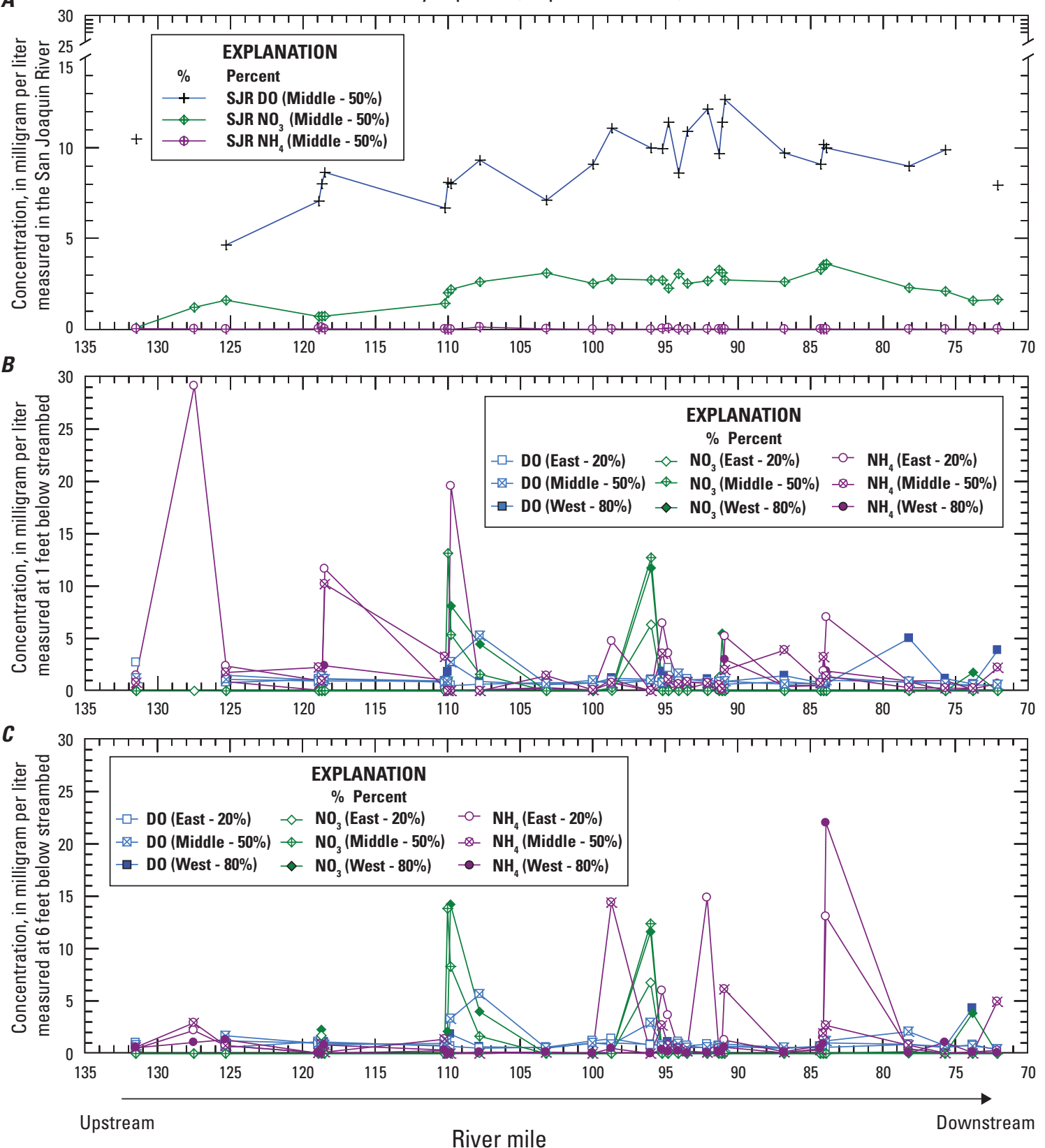

Figure 54. Comparison of dissolved oxygen (DO), nitrate $\left(\mathrm{NO}_{3}\right)$, and ammonium $\left(\mathrm{NH}_{4}\right)$ concentrations measured during Synoptic II in $A$, the San Joaquin River; $B, 1$ foot below the streambed; and $C, 6$ feet below the streambed. 


\section{Ammonium}

Ammonium concentrations greater than the MDL of $0.01 \mathrm{mg} / \mathrm{L}$ were observed in the majority of the 113 crosssectional transects (fig. 55). Maximum ammonium concentration in the groundwater was nearly $30 \mathrm{mg} / \mathrm{L}$, and this is several orders of magnitude greater than the concentrations found in the SJR (generally less than $0.05 \mathrm{mg} / \mathrm{L}$ ). Generalizing to the entire 59-mi study reach, ammonium concentrations tended to be higher at the $1-\mathrm{ft}$ depth than at the 6-ft depth, and ammonium concentrations tended to be higher in east-side compared to west-side samples. We hypothesized two mechanisms to explain these ammonium concentrations: 1 ) dissimilatory nitrate reduction to ammonium (fermentative or sulfide reduction) or 2) anoxic mineralization of river sediments. Previous laboratory studies of SJR sediments spiked with nitrate under anoxic conditions (Zhang and Dahlgren, 2009) showed a rapid loss of nitrate with no detectable increase in ammonium concentration, indicating that dissimilatory nitrate reduction to ammonium (fermentative or sulfide reduction) was not the source of ammonium. In contrast, a 14-day anoxic incubation of sediments with no added nitrate did generate ammonium, presumably due to mineralization of organic matter contained within the sediments (Zhang and Dahlgren, 2009).

The mechanism of ammonium generation from anoxic sediments (hypothesis 2 stated above) is well supported by studies from lakes and estuaries (Beutel, 2006; Lai and Lam, 2008). Once ammonium is generated in anoxic environments, it tends to be stable because of a lack of oxygen necessary for nitrification $\left(\mathrm{NH}_{4} \rightarrow \mathrm{NO}_{3}\right)$. Because ammonium exists as a cation at the ambient $\mathrm{pH}$ values, its mobility can be attenuated by its attraction to cation-exchange sites, including those on the organic matter in the sediments. In the laboratory study (Zhang and Dahlgren, 2009), the highest ammonium concentrations were observed in finer-grained sediment containing higher organic matter concentrations and slower diffusion/mass-flow transport.
Ammonium concentrations were greater than $1.0 \mathrm{mg} / \mathrm{L}$ at sixteen transects during Synoptic I (fig. 53) and at eighteen transects during Synoptic II (fig. 54). These higher concentrations coincided with measured dissolved oxygen concentrations of less than $2 \mathrm{mg} / \mathrm{L}$. The median dissolved oxygen concentrations measured in the streambed sediments during Synoptic I and II at the 1-ft depth and 6-ft depth were 1.12 and $0.90 \mathrm{mg} / \mathrm{L}$, respectively. Further investigation would be needed to verify the origin of the ammonium in SJR sediments and to determine potential rates of ammonium transport to surface waters. Once in the surface waters, the presence of oxygen tends to facilitate nitrification of the ammonium to nitrate.

\section{Dissolved Organic Carbon}

DOC concentrations were highly variable in SJR groundwater, generally ranging from 1 to $5 \mathrm{mg} / \mathrm{L}$, with maximum concentrations in the $15-18 \mathrm{mg} / \mathrm{L}$ range (fig. 56). Generalizing to the entire 59-mi study reach, DOC concentrations tended to be higher at the 1 -ft depth (median of $2.3 \mathrm{mg} / \mathrm{L}$ ) compared to the 6 -ft depth (median of $1.3 \mathrm{mg} / \mathrm{L}$ ), and DOC concentrations tended to be higher in east-side (median of $2.0 \mathrm{mg} / \mathrm{L}$ ) than in west-side samples (median of $1.8 \mathrm{mg} / \mathrm{L}$; fig. 56). In the majority of cases, the DOC concentrations in surface waters $(3-5 \mathrm{mg} / \mathrm{L}$ ) tended to be slightly higher than concentrations in the groundwater (median of $1.92 \mathrm{mg} / \mathrm{L}$ measured during Synoptics I-IV). Assuming a generally upward hydraulic gradient based on measurements made during Synoptics I-III (figs. 38-40), the source of the DOC would be predominantly from the release of DOC originating from organic matter incorporated into the sediments. However, the high DOC concentrations at the 1 -ft depth could reflect some DOC originating from surface waters. Given that DOC concentrations in groundwater were similar to or less than those in surface waters, we can conclude that the streambed and the riparian zone groundwater do not appreciably increase DOC concentrations in the overlying surface waters. 

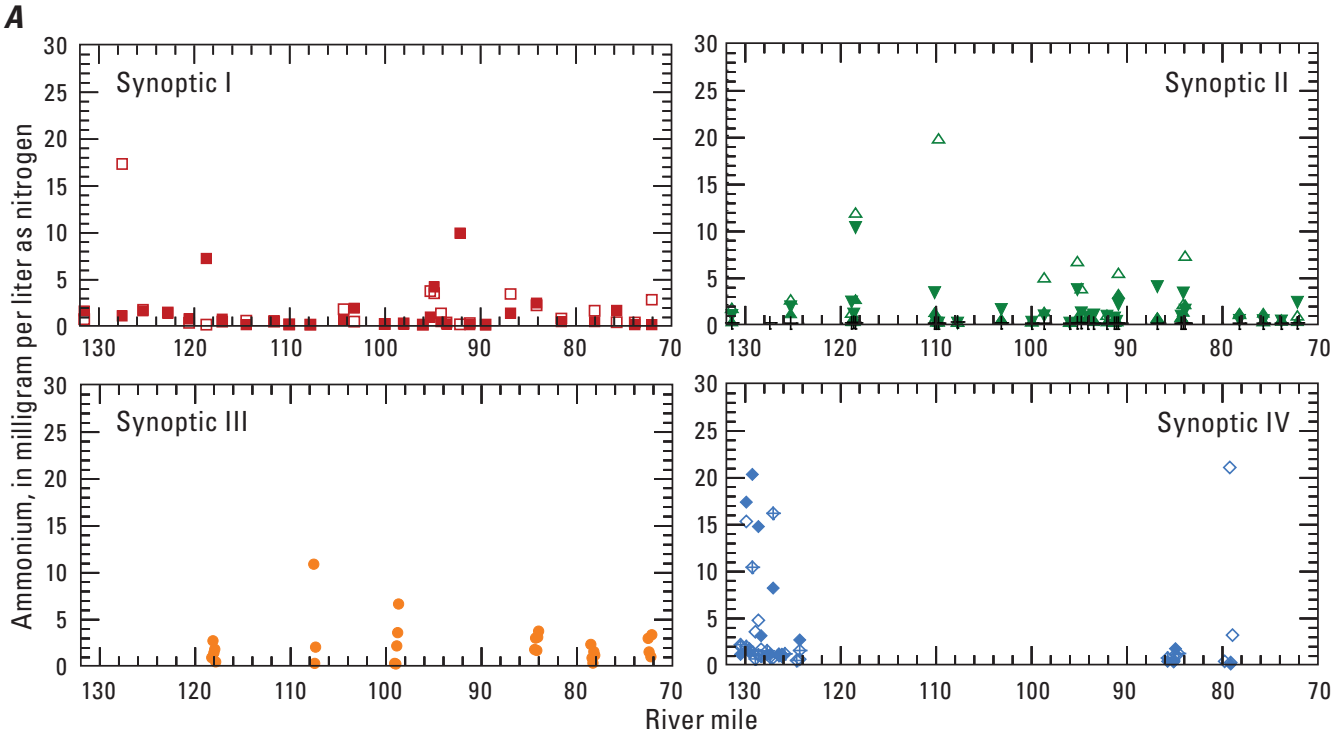

$B$
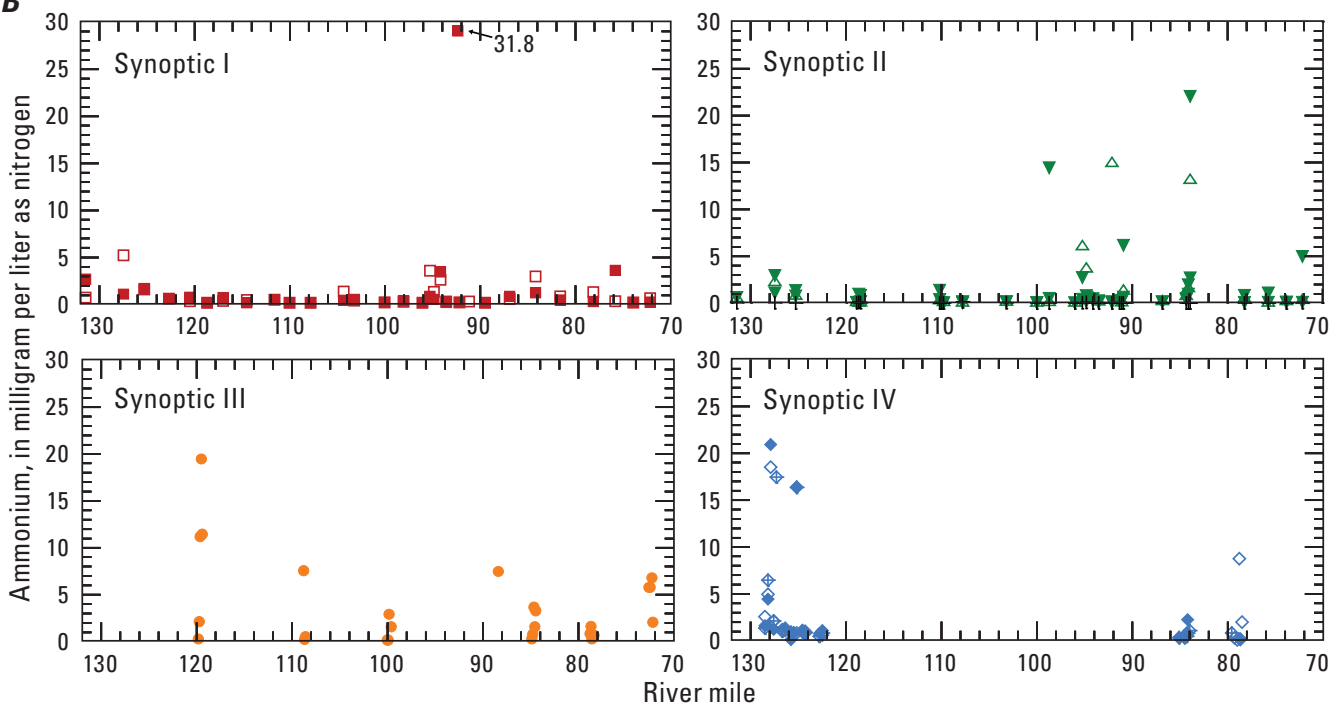

EXPLANATION

+ San Joaquin River ammonium

ㄱ SYN I- 20\%

$\triangle$ SYN II $-20 \%$

- SYN III - $\mathbf{5 0 \%}$

$\diamond$

SYNI-80\%

V SYN II - 50\%

- SYN IV - $50 \%$

- SYN II - $80 \%$

$\leftrightarrow \quad$ SYN IV - $80 \%$

Figure 55. Measured detections of ammonium $\left(\mathrm{NH}_{4}\right)$ concentrations for each transect for Synoptics (SYN) I-IV in $A$, shallow depth (1 foot) and $B$, deep depth (3-6 feet). For each synoptic, the location of the measurements at each transect was selected as a percentage of the total transect distance: 20 percent (\%) was considered the east bank, 50 percent was considered the midpoint, and 80 percent was considered the west bank. 

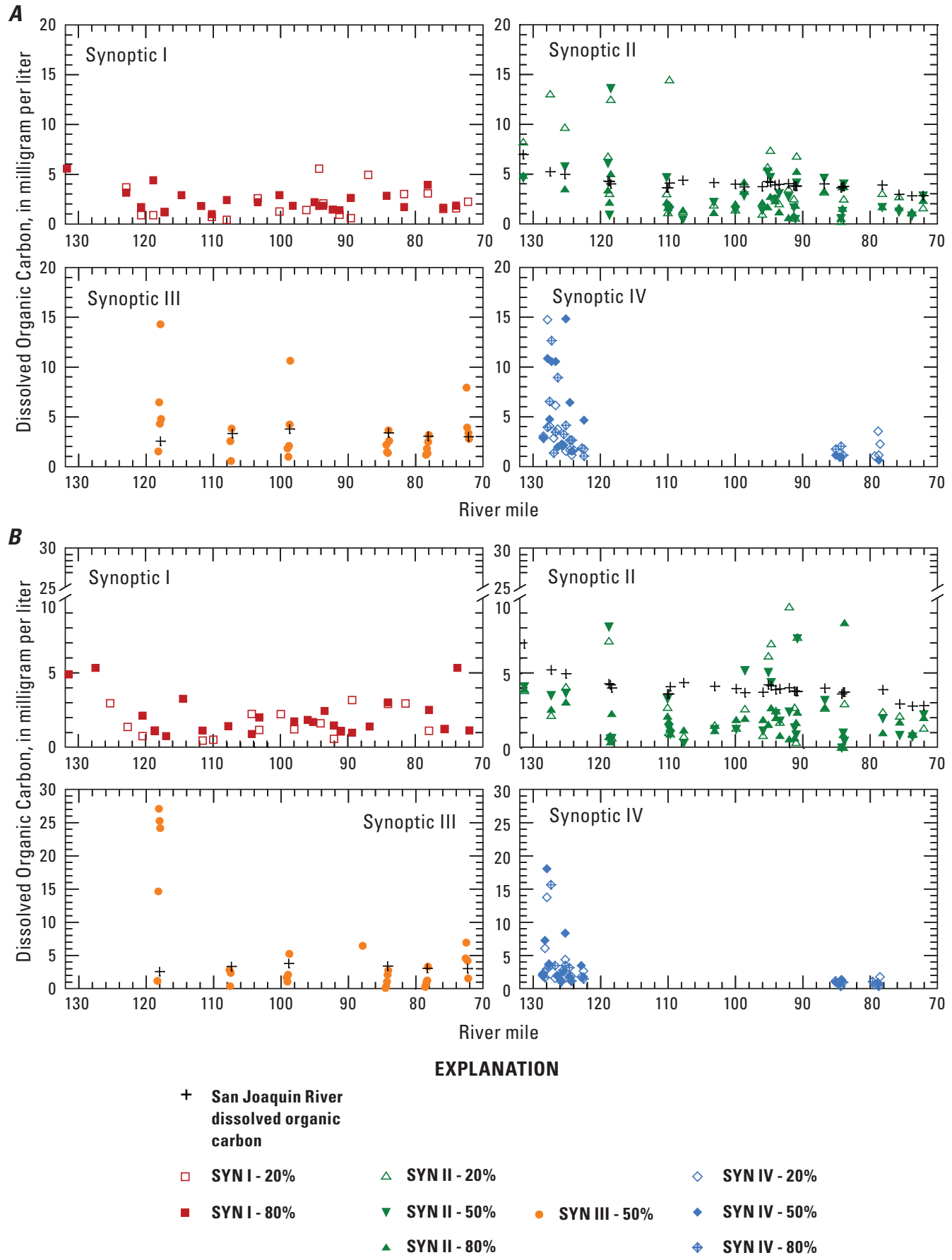

Figure 56. Measured detections of dissolved organic carbon (DOC) concentrations for each transect for Synoptics (SYN) I-IV in $A$, shallow depths (1 foot) and $B$, deep depths (3-6 feet). For each synoptic, the location of the measurements at each transect was selected as a percentage of the total transect distance: 20 percent (\%) was considered the east bank, 50 percent was considered the midpoint, and 80 percent was considered the west bank. 


\section{Water-Quality Results from the Longitudinal Profile Surveys}

Continuous measurements for color dissolved organic matter (CDOM), chlorophyll- $\alpha$, nitrate, and other waterquality parameters (temperature, $\mathrm{pH}, \mathrm{SC}$, dissolved oxygen, and turbidity) were collected during the longitudinal profile surveys. This approach allowed rapid identification of nitrate contributions, which was useful for coordinating efforts with the streambed synoptic surveys. The longitudinal profiles (upstream to downstream) revealed areas of higher and lower concentration of nitrate and CDOM from inflows and tributary contributions within the 59-mi reach. Some tributaries had higher concentrations of nitrate and CDOM compared to concentrations in the SJR, while other inflows did not. Lagrangian and cross-channel tracing of nitrate below the confluences of certain inflows showed that higher concentrations of nitrate were observed in the center of the channel (center of flow) compared to concentrations observed on either side (left and right stream bank) of the center of flow (between wetted stream banks and center of flow). The high sampling frequency of the instrumentation system proved capable of recording small-scale variability within specific river reaches. The results of the longitudinal profiles are presented by date of survey.

\section{August 2007}

In general, the CDOM fluorescence and SC concentrations decreased downstream over the longitudinal profile (river miles 130 to 72; figs. 57 and 58), whereas estimated chlorophyll- $\alpha$ concentrations increased downstream over the longitudinal profile (fig. 59) during the sampling period (August 13-16, 2007). Cooler water temperatures were consistent with prominent inflows including some agricultural drains (fig. 60). Lower CDOM values were measured at the major river inflows (that is, Merced River, river mile 118; Tuolumne River, river mile 84; and Stanislaus River, river mile 75), whereas other inflows revealed increased CDOM (that is, Harding Drain, river mile 103; Modesto WWTP, river mile 95). Dissolved oxygen levels were variable throughout the longitudinal profile, with most of the variability attributable to inflows (fig. 61). Interestingly, dissolved oxygen was lowest toward the downstream end of the reach at Vernalis (river mile 72). SC increased from Salt Slough (river mile 130) and reached a maximum value of $1.6 \mathrm{mS} / \mathrm{cm}$ at the Mud Slough confluence (river mile 121) and (fig. 59). 


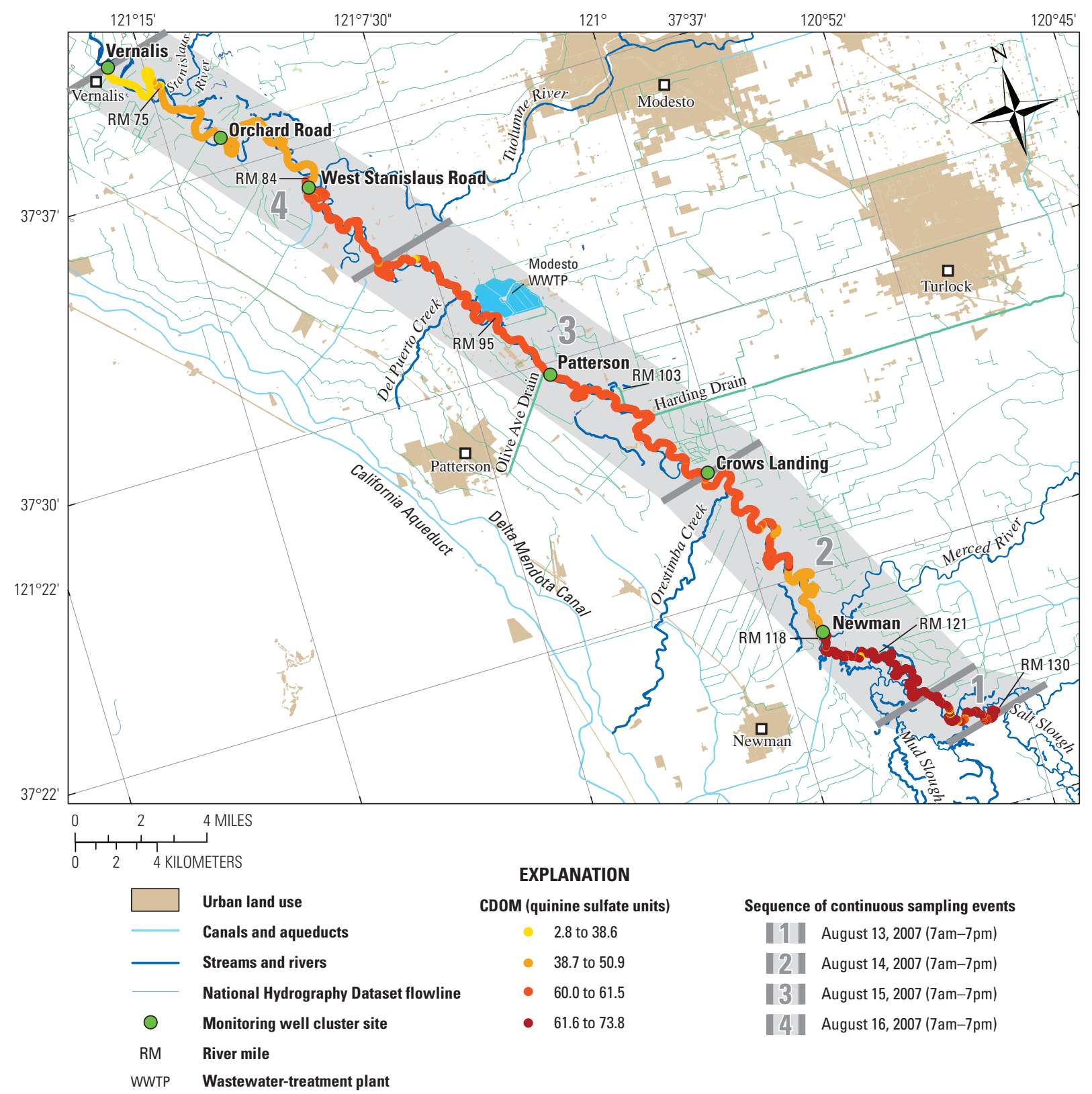

Figure 57. Colored dissolved organic matter (CDOM) fluorescence measurements recorded during the longitudinal profile survey over the 59-mile reach of the San Joaquin River during Synoptic I, August 2007. 


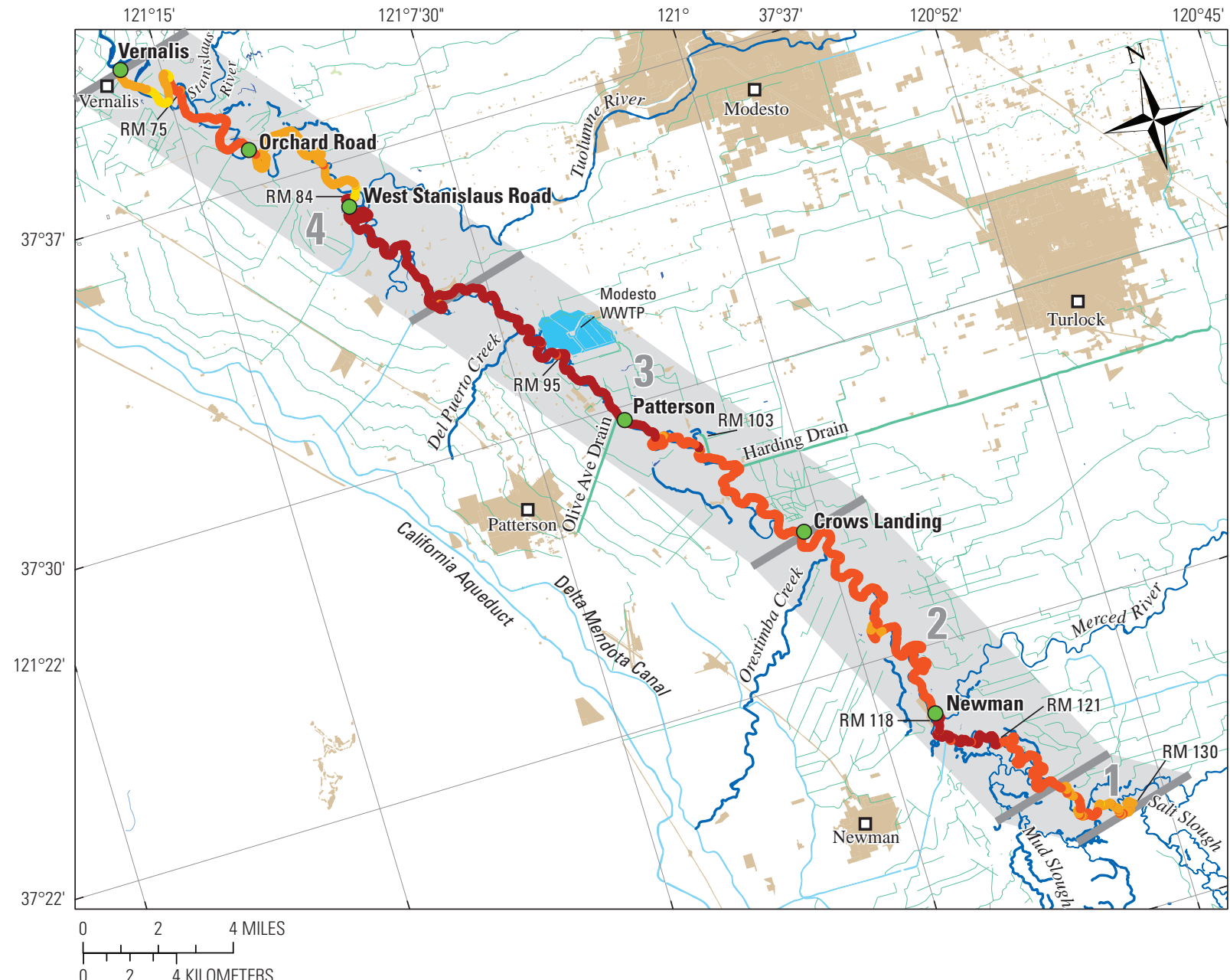

\begin{tabular}{ll}
\hline & Urban land use \\
\hdashline & Canals and aqueducts \\
& Streams and rivers \\
& National Hydrography Dataset flowline \\
& Monitoring well cluster site \\
RM & River mile \\
WWTP & Wastewater-treatment plant
\end{tabular}

SC (millisiemens per centimeter)

0.0 to 0.5

0.6 to 0.9

- 1.0 to 1.2

- $\quad 1.3$ to 1.6
Sequence of continuous sampling events

1 August 13, 2007 (7am-7pm)

2 August 14, 2007 (7am-7pm)

3 August 15, 2007 (7am-7pm)

4 August 16, 2007 (7am-7pm)

Figure 58. Specific conductivity (SC) measurements recorded during the longitudinal profile survey over the 59-mile reach of the San Joaquin River during Synoptic I, August 2007. 


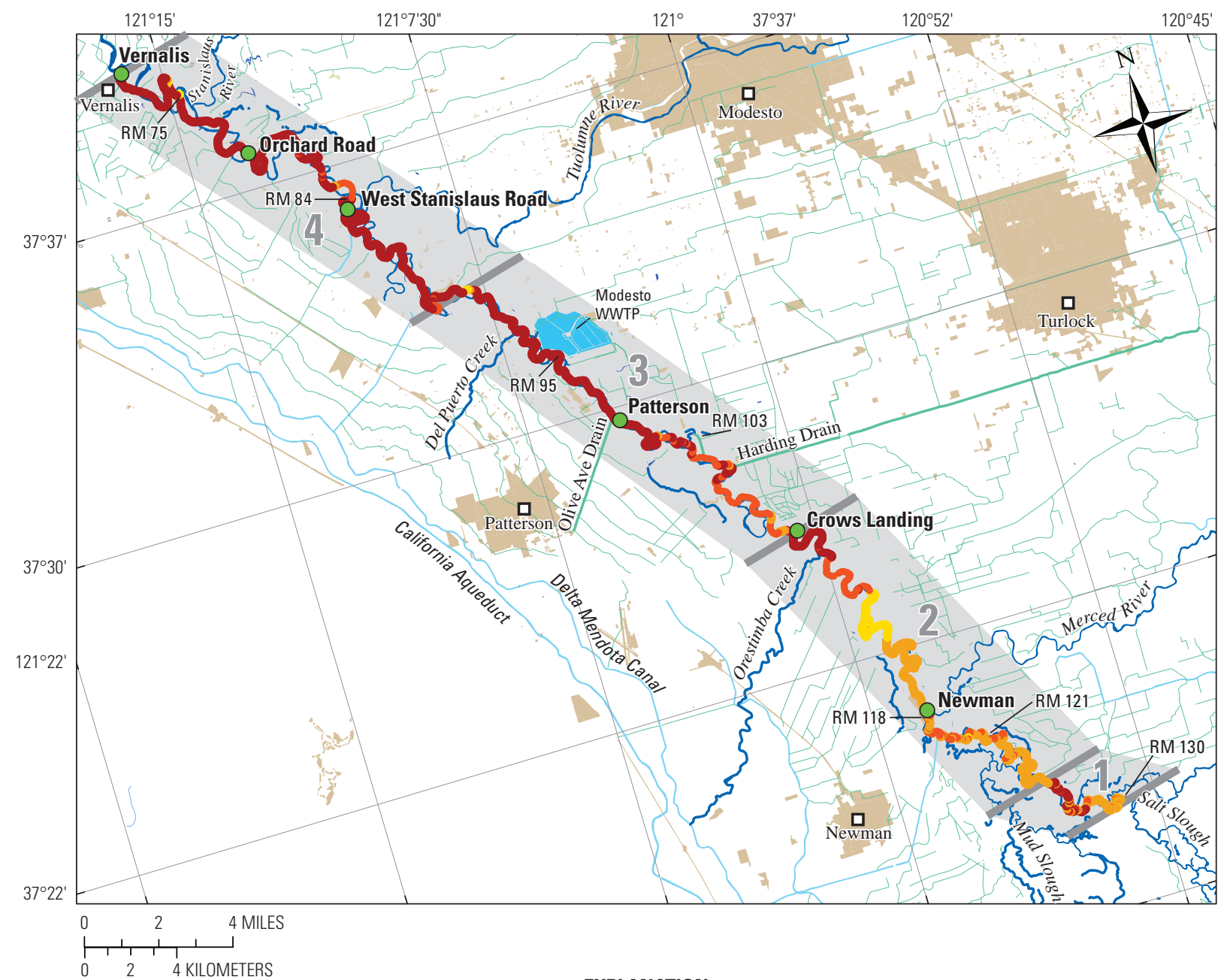

\section{EXPLANATION}

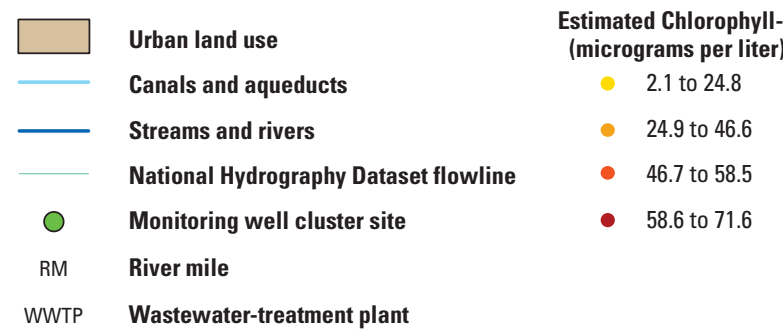

Sequence of continuous sampling events

11. August 13, $2007(7 \mathrm{am}-7 \mathrm{pm})$

2. August $14,2007(7 \mathrm{am}-7 \mathrm{pm})$

1. August 15, 2007 (7am-7pm)

4 | August 16, 2007 (7am-7pm)

Figure 59. Estimated chlorophyll- $\alpha$ concentration measurements recorded during the longitudinal profile survey over the 59-mile reach of the San Joaquin River during Synoptic I, August 2007. 

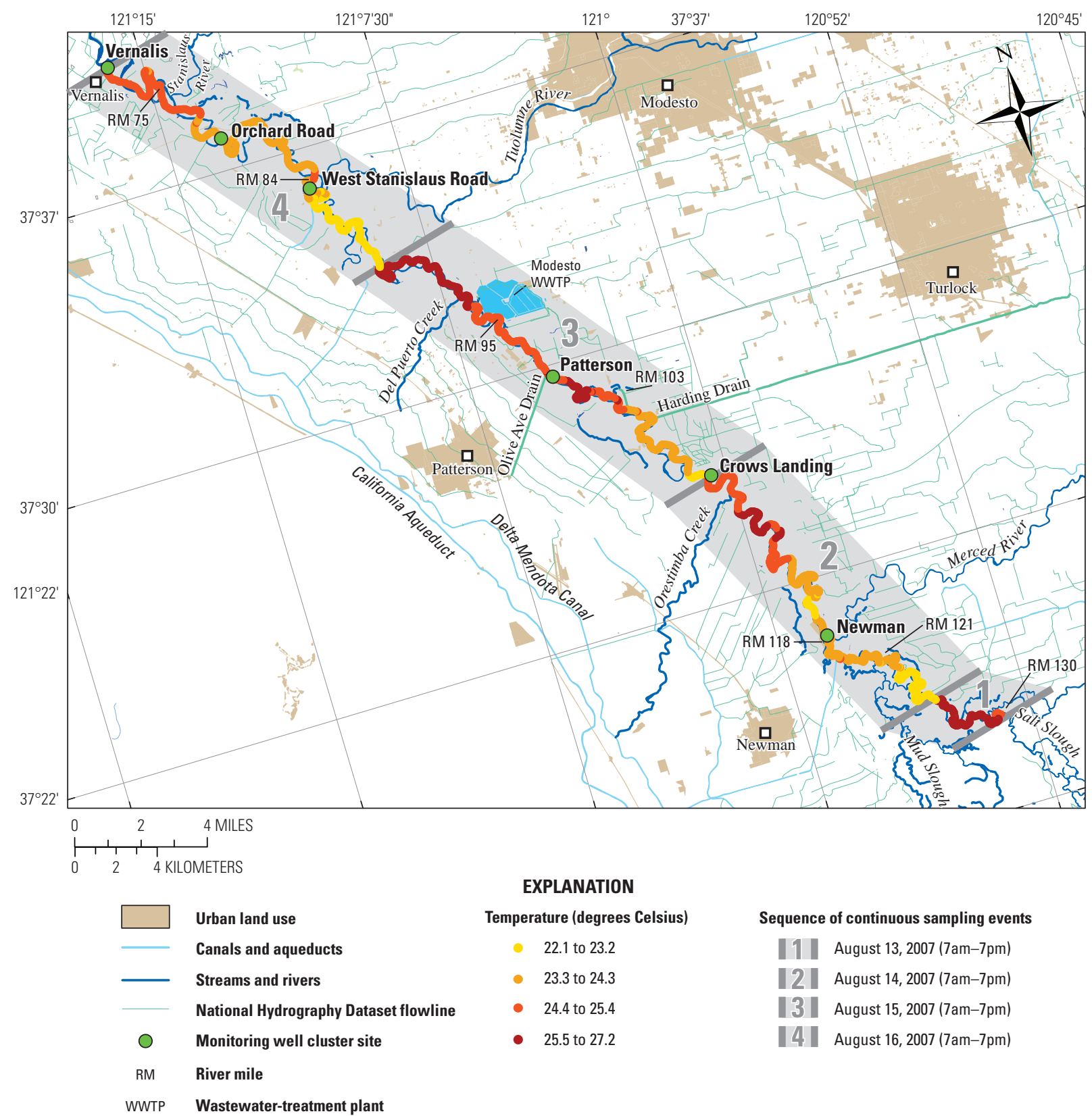

\begin{tabular}{|c|c|c|}
\hline \multicolumn{2}{|c|}{ Temperature (degrees Celsius) } & Sequence of continuous sampling event \\
\hline - & 22.1 to 23.2 & 1 August 13, 2007 (7am-7pm) \\
\hline - & 23.3 to 24.3 & 2 August 14, 2007 (7am-7pm) \\
\hline - & 24.4 to 25.4 & 3 August 15, 2007 (7am-7pm) \\
\hline - & 25.5 to 27.2 & 4 August 16, 2007 (7am-7pm) \\
\hline
\end{tabular}

Figure 60. Temperature measurements recorded during the longitudinal profile survey over the 59 -mile reach of the San Joaquin River during Synoptic I, August 2007. 


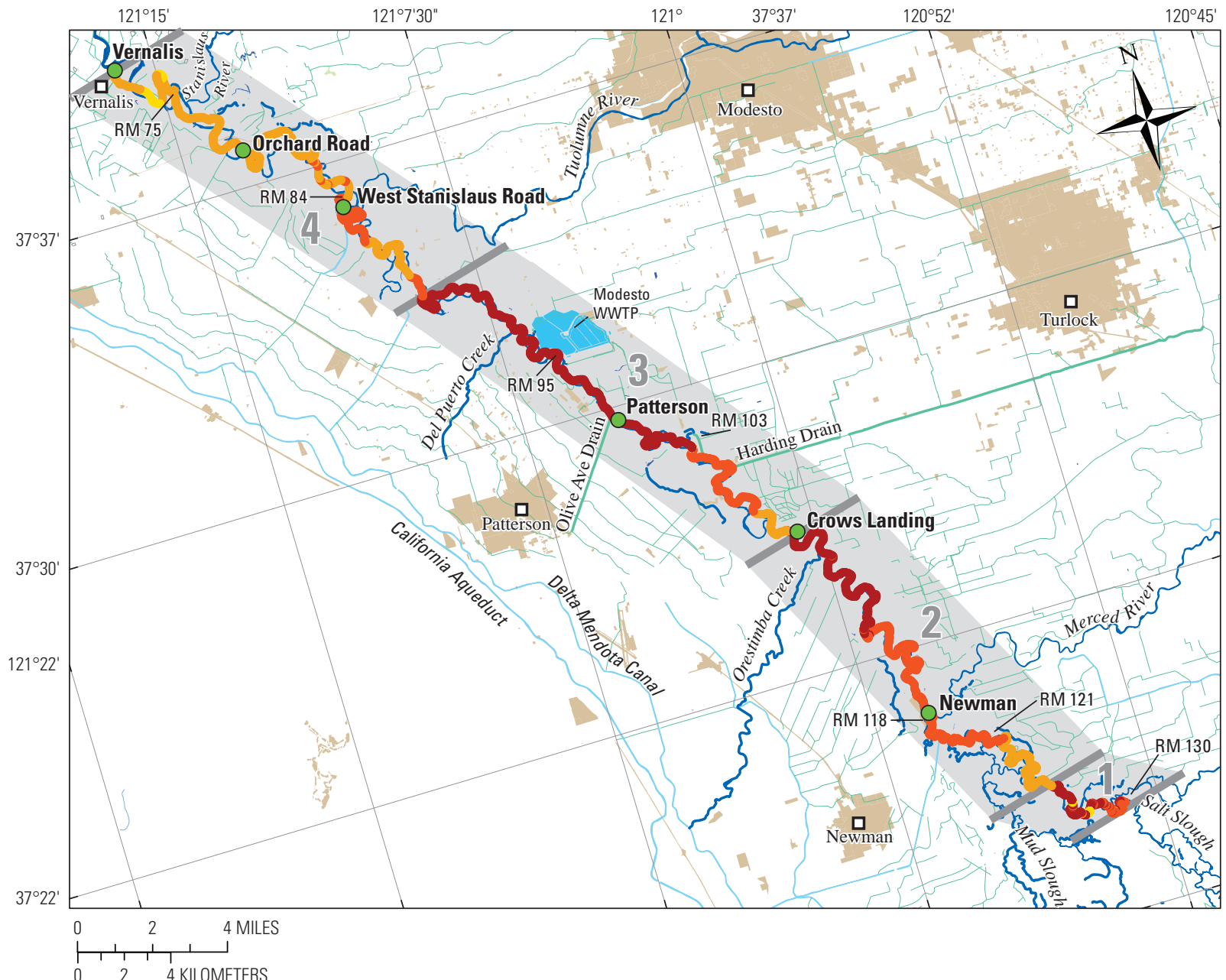

EXPLANATION

\begin{aligned} \hline & Urban land use \\ \hline & Canals and aqueducts \\ \hline & Streams and rivers \\ & National Hydrography Dataset flowline \\ \hdashline & Monitoring well cluster site \\ RM & River mile \\ WWTP & Wastewater-treatment plant \end{aligned}

\begin{tabular}{|c|c|c|}
\hline \multicolumn{2}{|c|}{ DO (milligrams per liter) } & Sequence of continuous sampling events \\
\hline - & 0.8 to 5.2 & 1 August 13, 2007 (7am-7pm) \\
\hline - & 5.3 to 9.2 & August 14, 2007 (7am-7pm) \\
\hline 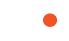 & 9.3 to 12.1 & August 15, 2007 (7am-7pm) \\
\hline - & 12.2 to 16.0 & 4 August 16, 2007 (7am-7pm) \\
\hline
\end{tabular}

Figure 61. Dissolved oxygen (DO) measurements recorded during the longitudinal profile survey over the 59-mile reach of the San Joaquin River during Synoptic I, August 2007.

\section{September 2008}

The ability to continuously measure nitrate concentrations using an optical sensor for nitrate was added in the 2008 longitudinal profile survey (September 9-12, 2008). Increases in nitrate concentrations were measured at Newman Wasteway (river mile 119), confluence of the Merced River (river mile 118), Orestimba Creek (river mile 109), Turlock WWTP (river mile 112), Harding Drain (river mile 103), and Olive Avenue Drain (river mile 98; fig. 62). Significant decreases in nitrate concentrations-by nearly 60 percentwere seen at Tuolumne and Stanislaus Rivers, where the tributary inflows diluted nitrate concentrations. Increases in CDOM fluoresence were simultaneous with nitrate additions and were also associated with net nitrate decreases at the inflows of the Tuolumne (river mile 84) and Stanislaus Rivers (river mile 75; fig. 63). Time of day and differences in depth along the longitudinal profile seemed to be major factors influencing estimated chlorophyll- $\alpha$ concentration. Variance in measured chlorophyll- $\alpha$ concentrations along the longitudinal 


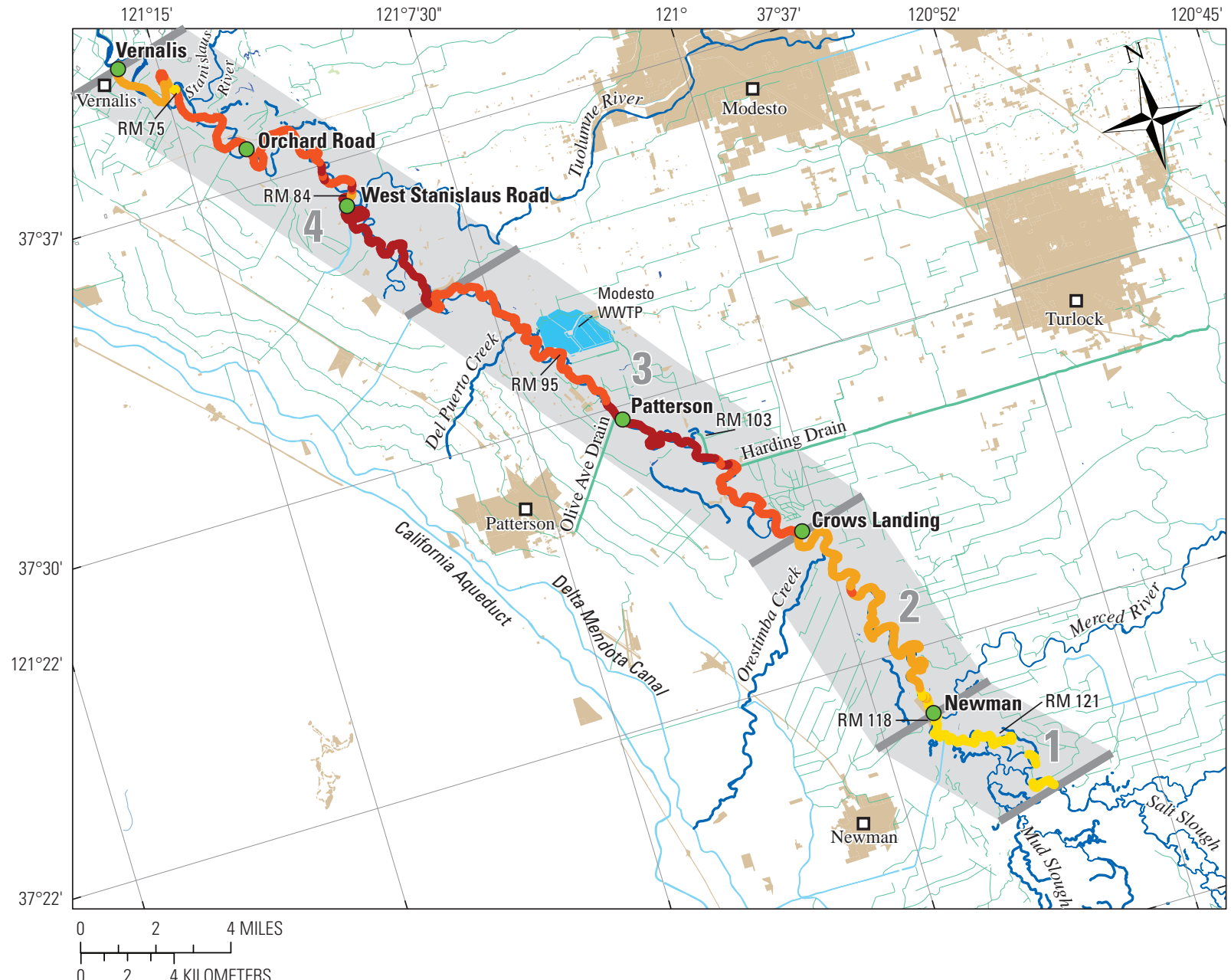

EXPLANATION

\begin{tabular}{|c|c|c|}
\hline & Urban land use & Nitrate (milligrams per liter) \\
\hline & Canals and aqueducts & 0.0 to 0.6 \\
\hline & Streams and rivers & 0.7 to 1.7 \\
\hline & National Hydrography Dataset flowline & - $\quad 1.8$ to 2.6 \\
\hline$\bigcirc$ & Monitoring well cluster site & - $\quad 2.7$ to 4.1 \\
\hline RM & River mile & \\
\hline WWTP & Wastewater-treatment plant & \\
\hline
\end{tabular}

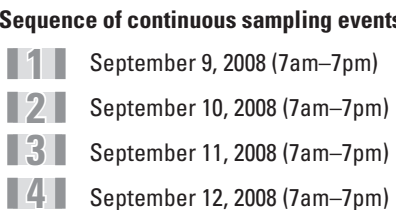

Figure 62. Nitrate concentration measurements recorded during the longitudinal profile survey over the 59-mile reach of the San Joaquin River during Synoptic II, September 2008.

profile seemed to relate to the prevalence of nitrate, DOM concentration, and water depth along the river transect (fig. 64). Shallow depths had lower estimated chlorophyll- $\alpha$ concentrations and presumably increased photo-exposure. The general trends in estimated chlorophyll- $\alpha$ concentration were consistent with the phytoplankton maximum usually seen toward the late afternoon hours (4-5 p.m.; Randy Dahlgren, UC Davis, personal commun.). The longitudinal profiles of temperature and dissolved oxygen were similar to those measured in the August 2007 longitudinal profile survey, with cooler temperatures encountered downstream of the Orchard Road site (figs. 65 and 66). The measured SC decreased from the Newman to the Patterson site, likely as a result of an increase in inflows received from the Merced River, a major east-side tributary, during September (fig. 67). This measured decrease in SC pattern also occurred downstream of the Tuolumne River and Stanislaus River inflows. 


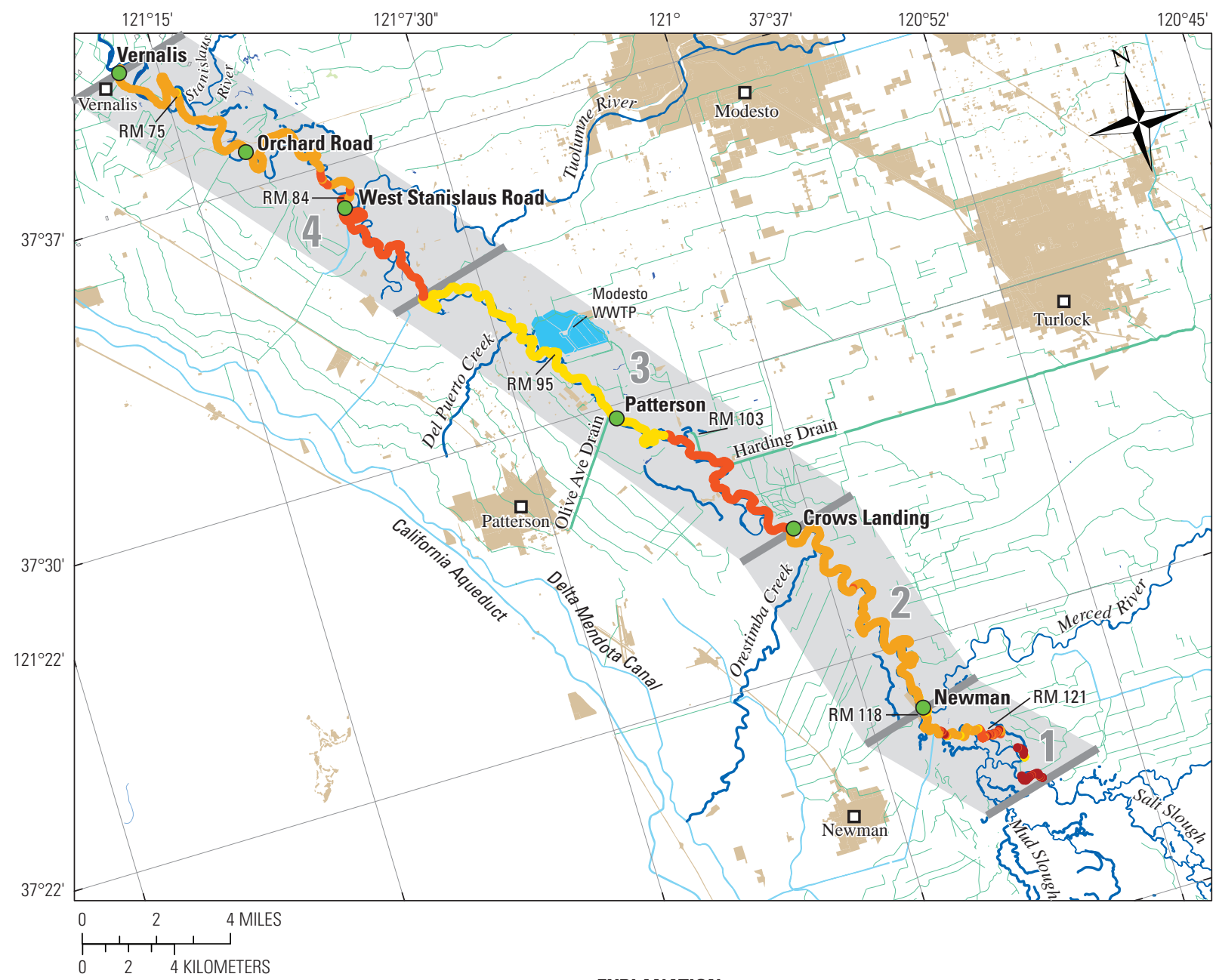

EXPLANATION

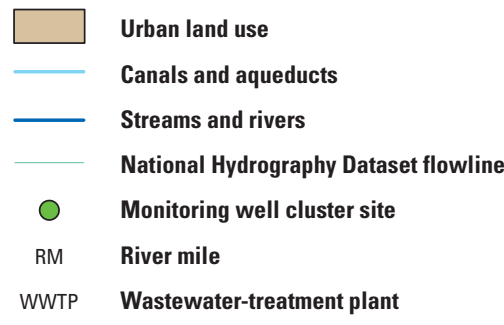

CDOM (quinine sulfate units)

0.0 to 16.2

- $\quad 16.3$ to 36.1

- 36.2 to 51.0

- $\quad 51.1$ to 72.5
Sequence of continuous sampling events

1 September 9, 2008 (7am-7pm)

2 September 10, 2008 (7am-7pm)

3 September 11, $2008(7 \mathrm{am}-7 \mathrm{pm})$

4 September 12, 2008 (7am-7pm)

Figure 63. Colored dissolved organic matter (CDOM) fluorescence measurements recorded during the longitudinal profile survey over the 59-mile reach of the San Joaquin River during Synoptic II, September 2008. 

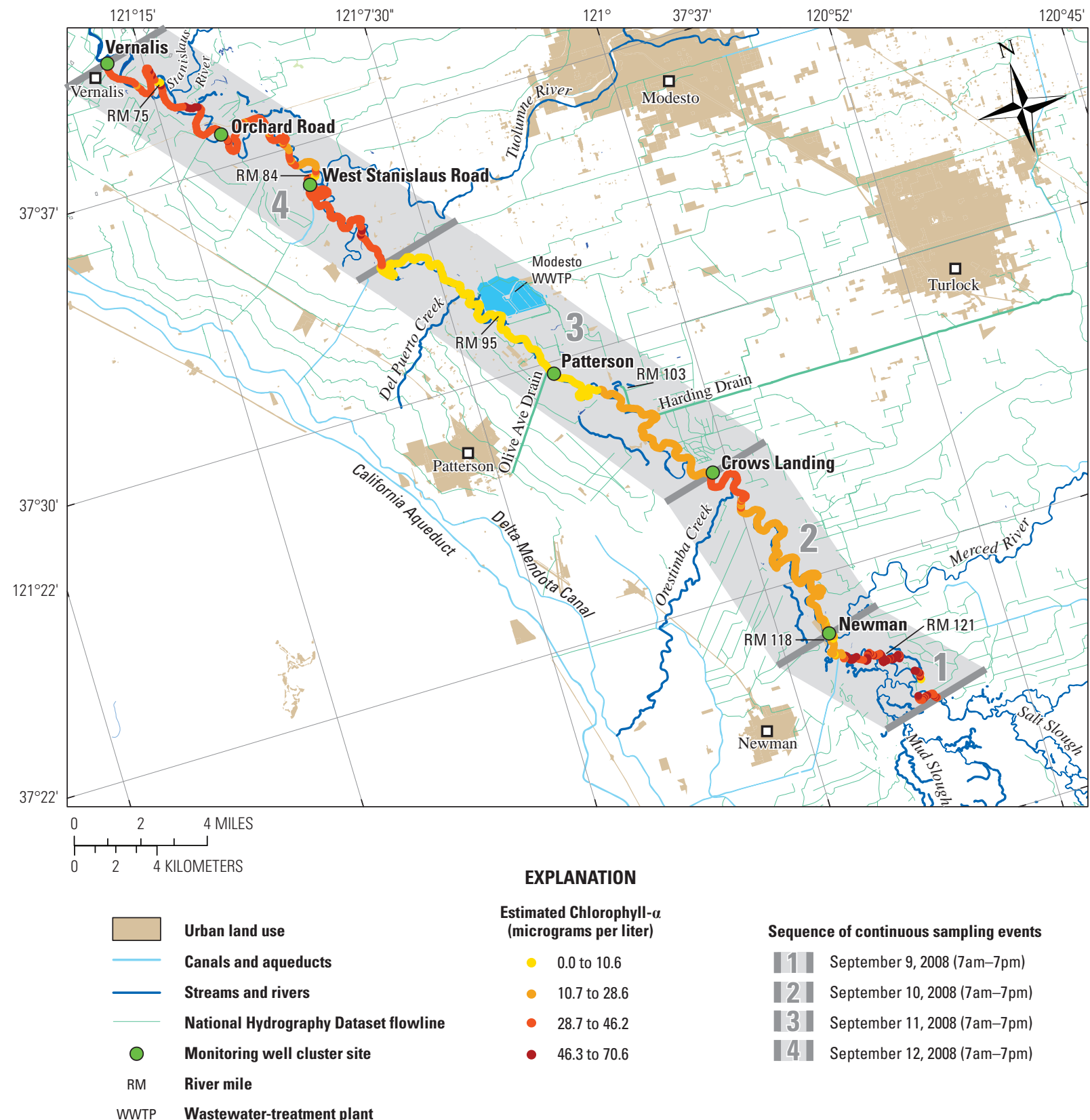

Estimated Chlorophyll-a

(micrograms per liter) Sequence of continuous sampling events

0.0 to $10.6 \quad 1$ September $9,2008(7 \mathrm{am}-7 \mathrm{pm})$

- 10.7 to $28.6 \quad 2$ September $10,2008(7 \mathrm{am}-7 \mathrm{pm})$

- 28.7 to $46.2 \quad 3$ September 11, $2008(7 \mathrm{am}-7 \mathrm{pm})$

- 46.3 to 70.6 September 12, $2008(7 \mathrm{am}-7 \mathrm{pm})$

WWTP Wastewater-treatment plant

Figure 64. Estimated chlorophyll- $\alpha$ concentration measurements recorded during the longitudinal profile survey over the 59-mile reach of the San Joaquin River during Synoptic II, September 2008. 


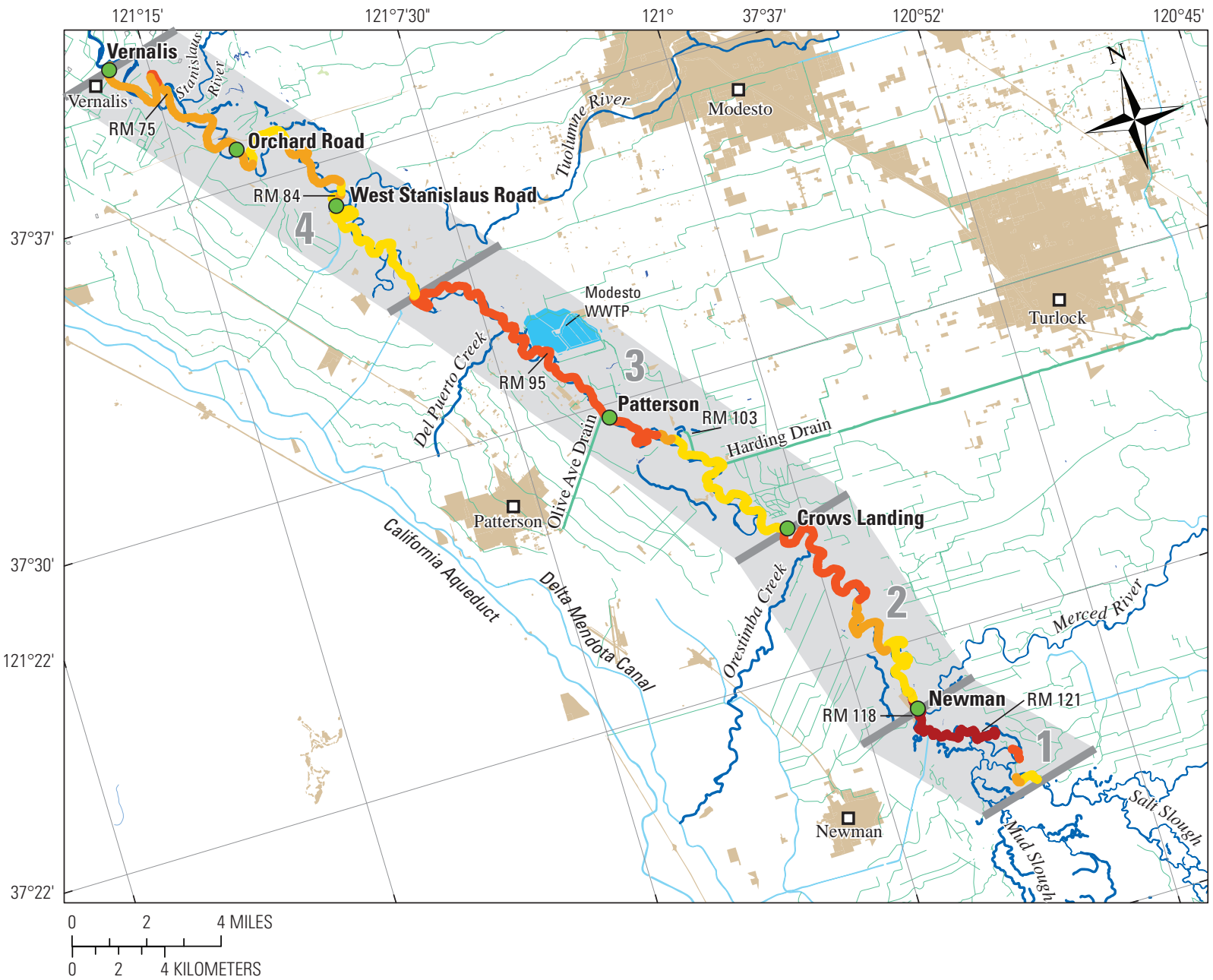

24 KILOMETERS

\begin{aligned} \hline & Urban land use \\ & Canals and aqueducts \\ & Streams and rivers \\ & National Hydrography Dataset flowline \\ & Monitoring well cluster site \\ RM & River mile \\ WWTP & Wastewater-treatment plant \end{aligned}

\begin{tabular}{|c|c|c|c|}
\hline Temperatı & e (degrees Celsius) & Sequen & e of continuous sampling events \\
\hline - & 21.6 to 22.6 & 1 & September 9, 2008 (7am-7pm) \\
\hline - & 22.7 to 23.6 & 12 & September 10, 2008 (7am-7pm) \\
\hline$\bullet$ & 23.7 to 24.9 & & September 11, 2008 (7am-7pm) \\
\hline$\bullet$ & 25.0 to 28.0 & 4 & September 12, 2008 (7am-7pm) \\
\hline
\end{tabular}

Figure 65. Temperature measurements recorded during the longitudinal profile survey over the 59-mile reach of the San Joaquin River during Synoptic II, September 2008. 


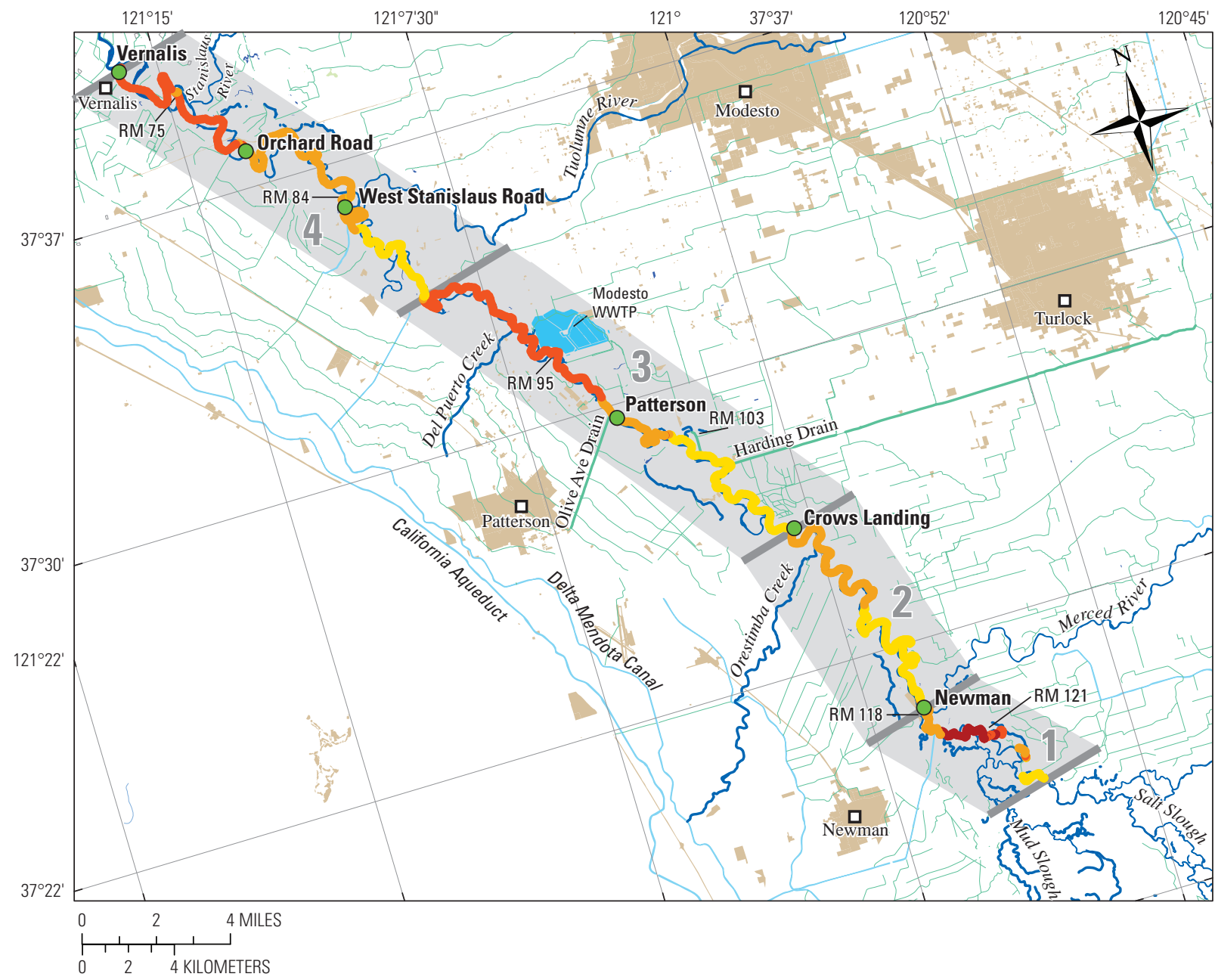

EXPLANATION

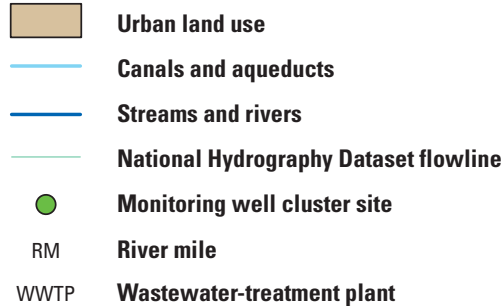

DO (milligrams per liter)

5.6 to 9.0

- 9.1 to 11.0

- $\quad 11.1$ to 13.5

- $\quad 13.6$ to 18.5
Sequence of continuous sampling events

1 September 9, 2008 (7am-7pm)

2 September 10, 2008 (7am-7pm)

3 September 11, 2008 (7am-7pm)

4 September 12, 2008 (7am-7pm)

Figure 66. Dissolved oxygen (DO) measurements recorded during the longitudinal profile survey over the 59-mile reach of the San Joaquin River during Synoptic II, September 2008. 


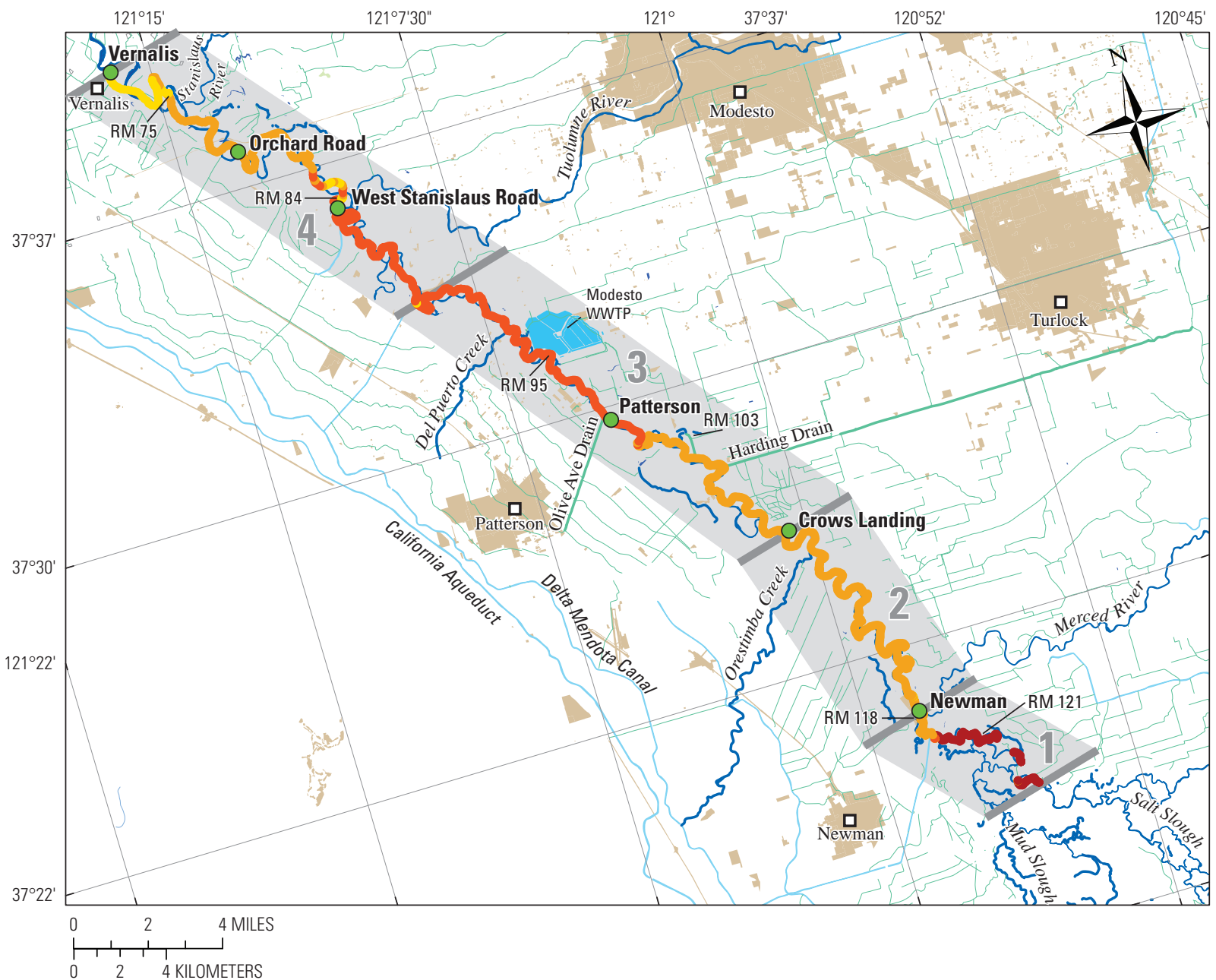

EXPLANATION

\begin{tabular}{cl}
\hline & Urban land use \\
\hline & Canals and aqueducts \\
& Streams and rivers \\
& National Hydrography Dataset flowline \\
\hline & Monitoring well cluster site \\
RM & River mile \\
WWTP & Wastewater-treatment plant
\end{tabular}

\begin{tabular}{|c|c|c|c|}
\hline \multicolumn{2}{|c|}{ SC (millisiemen per centimeter) } & \multicolumn{2}{|c|}{ Sequence of continuous sampling event } \\
\hline - & 0.1 to 0.5 & & September 9, 2008 (7am-7pm) \\
\hline - & 0.6 to 0.7 & 4 & September 10, 2008 (7am-7pm) \\
\hline$\bullet$ & 0.8 to 0.9 & 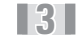 & September 11, 2008 (7am-7pm) \\
\hline - & 1.0 to 1.8 & 4 & September 12, 2008 (7am-7pm) \\
\hline
\end{tabular}

Figure 67. Specific conductivity (SC) measurements recorded during the longitudinal profile survey over the 59-mile reach of the San Joaquin River during Synoptic II, September 2008.

\section{October 2008}

The October 2008 longitudinal profile was completed over a 2-day period (October 15-16, 2008) using boat speeds approximately two times faster than those used in the two previous longitudinal surveys to test the efficiency of the longitudinal profile survey method. The nitrate instrumentation was removed during this survey because it was not feasible to obtain filtered nitrate measurements at the boat speed used. CDOM fluorescence, SC, and temperature decreased moving downstream (river miles 117 to 72; figs. 68-70). CDOM fluorescence (fig. 68) data were consistent with the 


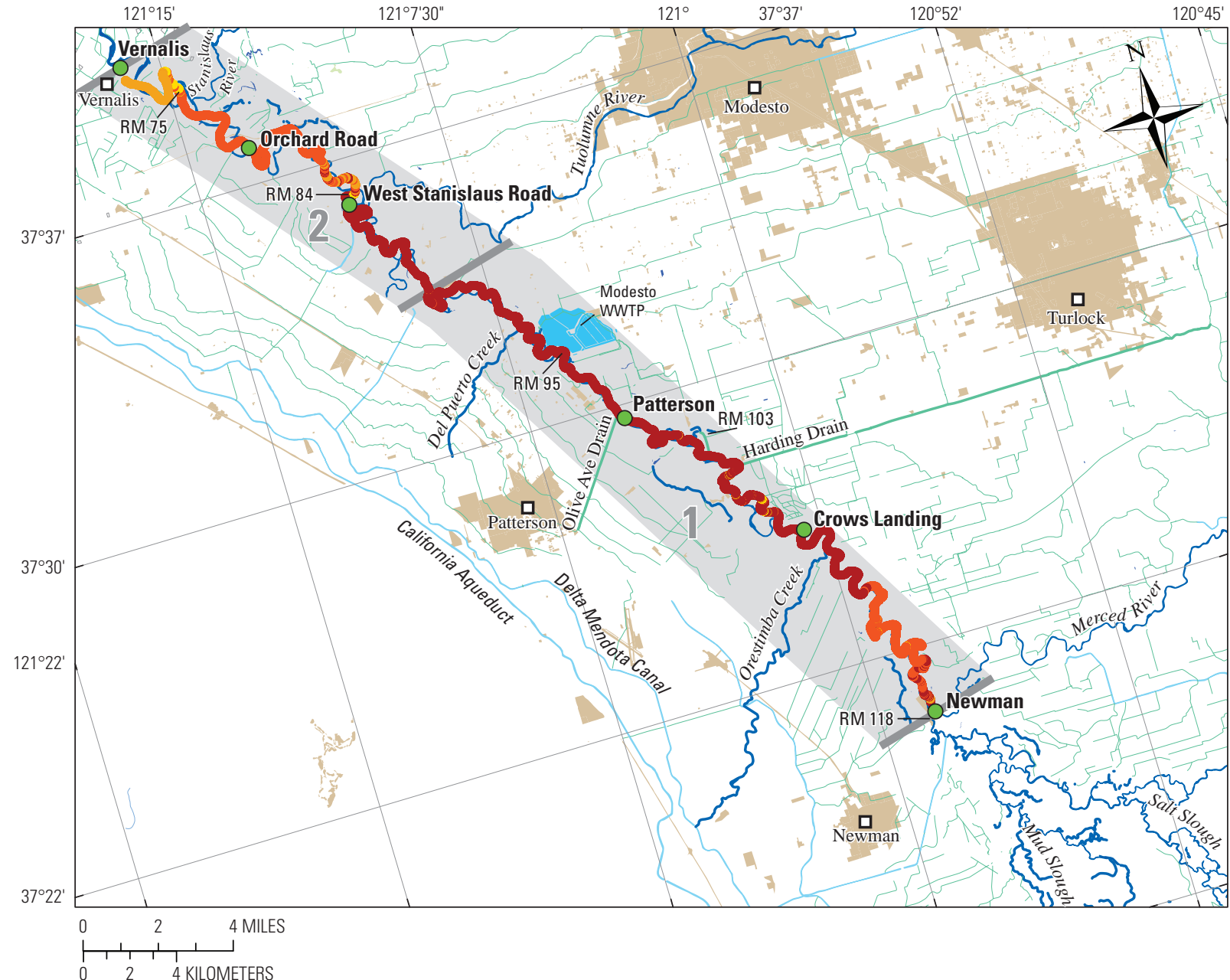

EXPLANATION

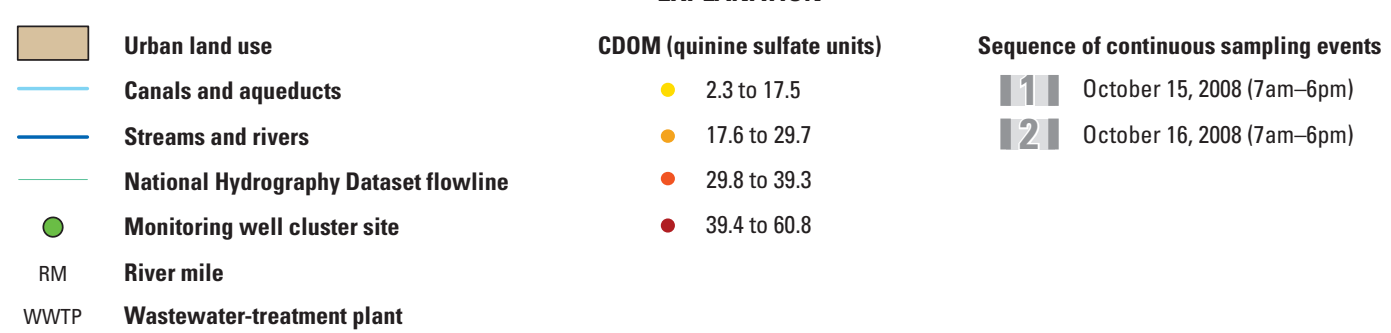

Figure 68. Colored dissolved organic matter (CDOM) fluorescence measurements recorded during the longitudinal profile survey over a 45-mile reach of the San Joaquin River during October 2008.

2008 September longitudinal profile (fig. 63), while estimated chlorophyll- $\alpha$ concentrations in this survey (fig. 71) were markedly lower than concentrations measured in September (fig. 64). October water temperatures (fig. 70) were much lower than temperatures in the previous month, most likely the result of cooler weather and increased water releases during October from east-side tributaries and reservoirs. Dissolved oxygen levels were relatively constant throughout the measured longitudinal profile, with most concentrations ranging from 8 to $10 \mathrm{mg} / \mathrm{L}$; however, an approximate 10 percent increase occurred over each day of the trip (fig. 72). 


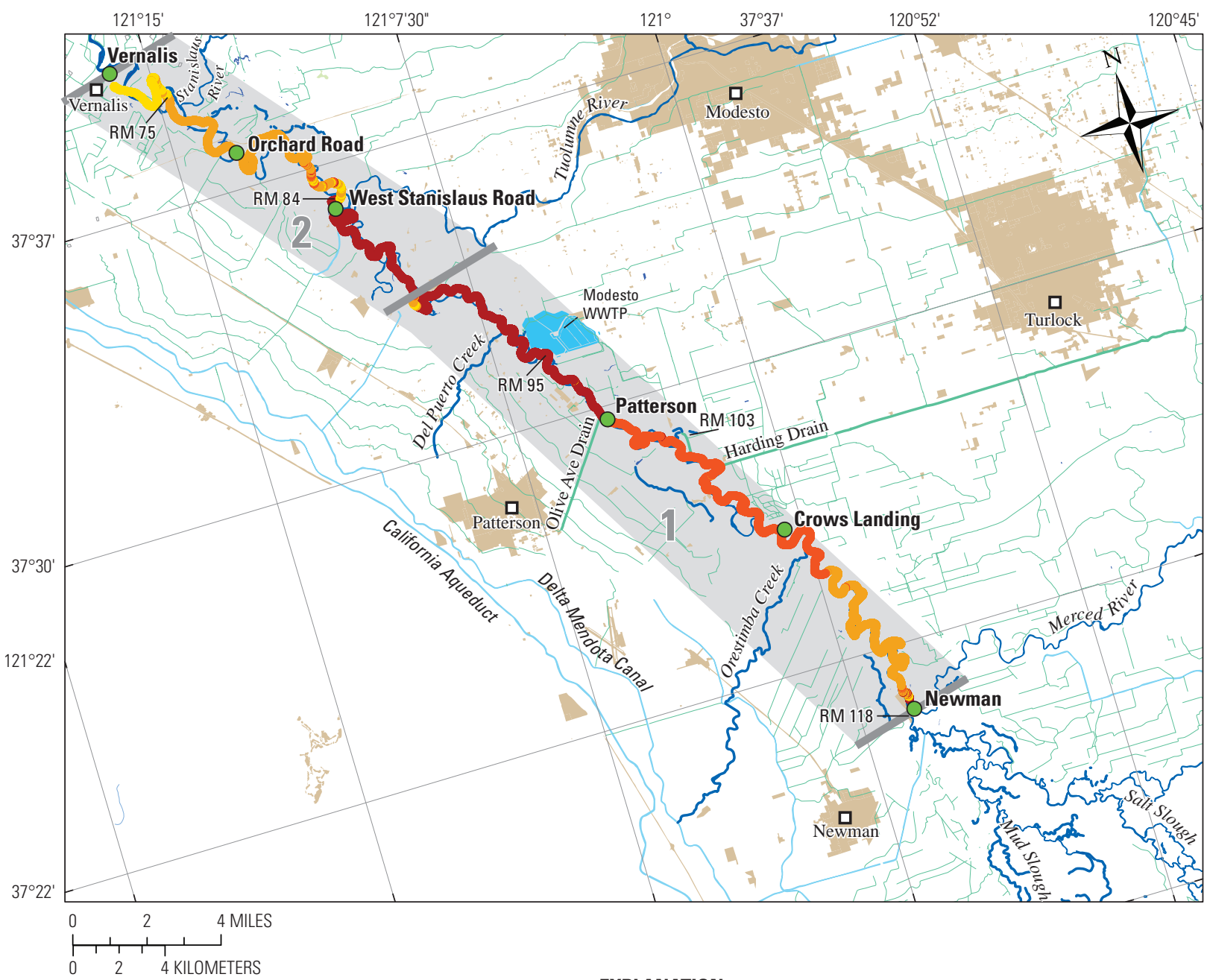

EXPLANATION

\begin{tabular}{r|l}
\hline & Urban land use \\
& Canals and aqueducts \\
& Streams and rivers \\
& National Hydrography Dataset flowline \\
& Monitoring well cluster site \\
RM & River mile \\
WWTP & Wastewater-treatment plant
\end{tabular}

SC (millisiemens per centimeters) Sequence of continuous sampling events

0.1 to 0.5

0.6 to 0.7

1 October 15, 2008 (7am-6pm)

- 0.8 to 0.9

- 1.0 to 1.1

WWTP Wastewater-treatment plant

Figure 69. Specific conductivity (SC) measurements recorded during the longitudinal profile survey over a 45-mile reach of the San Joaquin River during October 2008. 


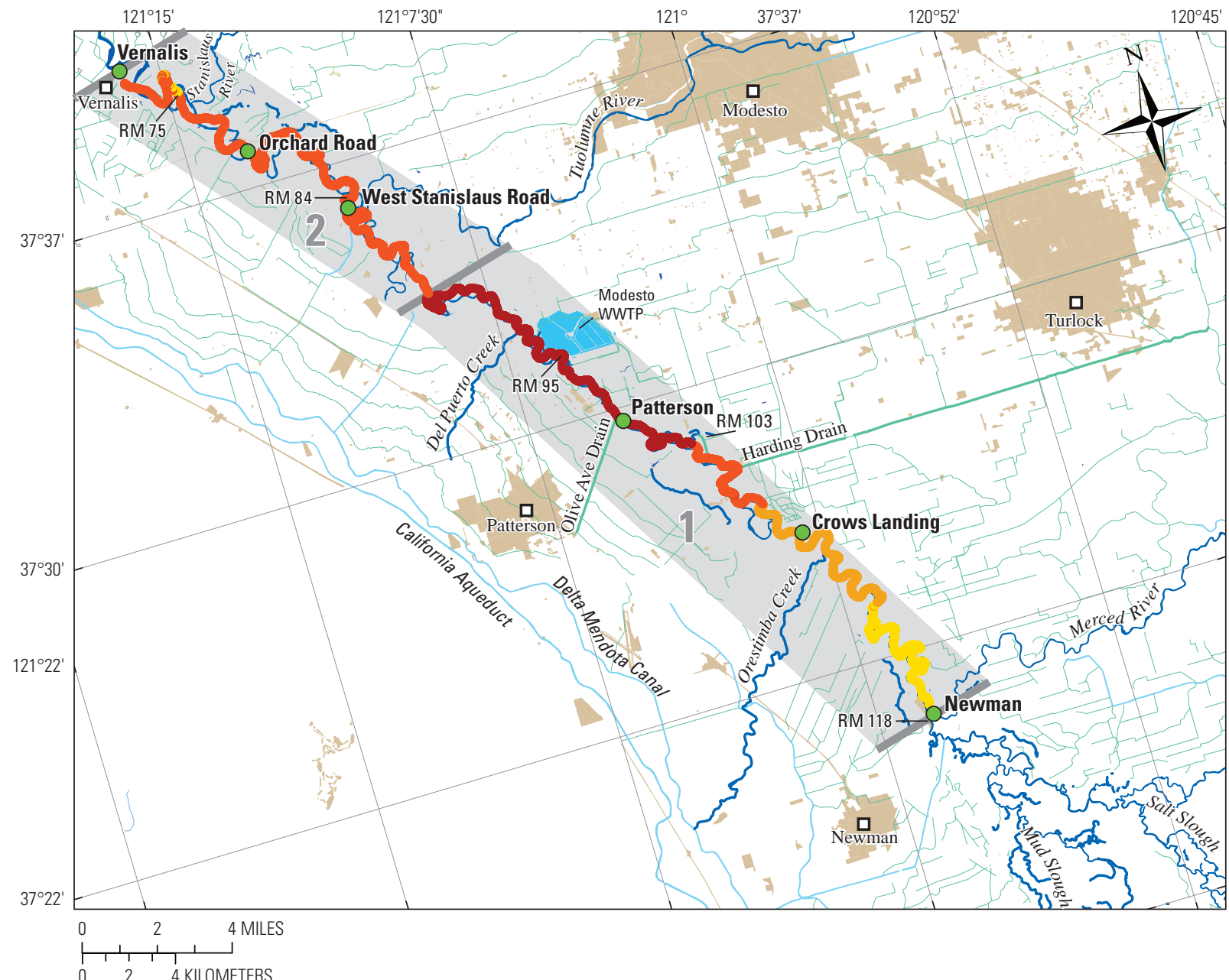

EXPLANATION

\begin{aligned} \hline & Urban land use \\ \hline & Canals and aqueducts \\ \hline & Streams and rivers \\ & National Hydrography Dataset flowline \\ \hdashline & Monitoring well cluster site \\ RM & River mile \\ WWTP & Wastewater-treatment plant \end{aligned}

Temperature (degrees Celsius)

13.5 to 14.3

14.4 to 15.2

- $\quad 15.3$ to 16.3

- 16.4 to 17.5
Sequence of continuous sampling events

1 October 15, 2008 (7am-6pm)

2 October 16, $2008(7 \mathrm{am}-6 \mathrm{pm})$

Figure 70. Temperature measurements recorded during the longitudinal profile survey over a 45-mile reach of the San Joaquin River during October 2008. 


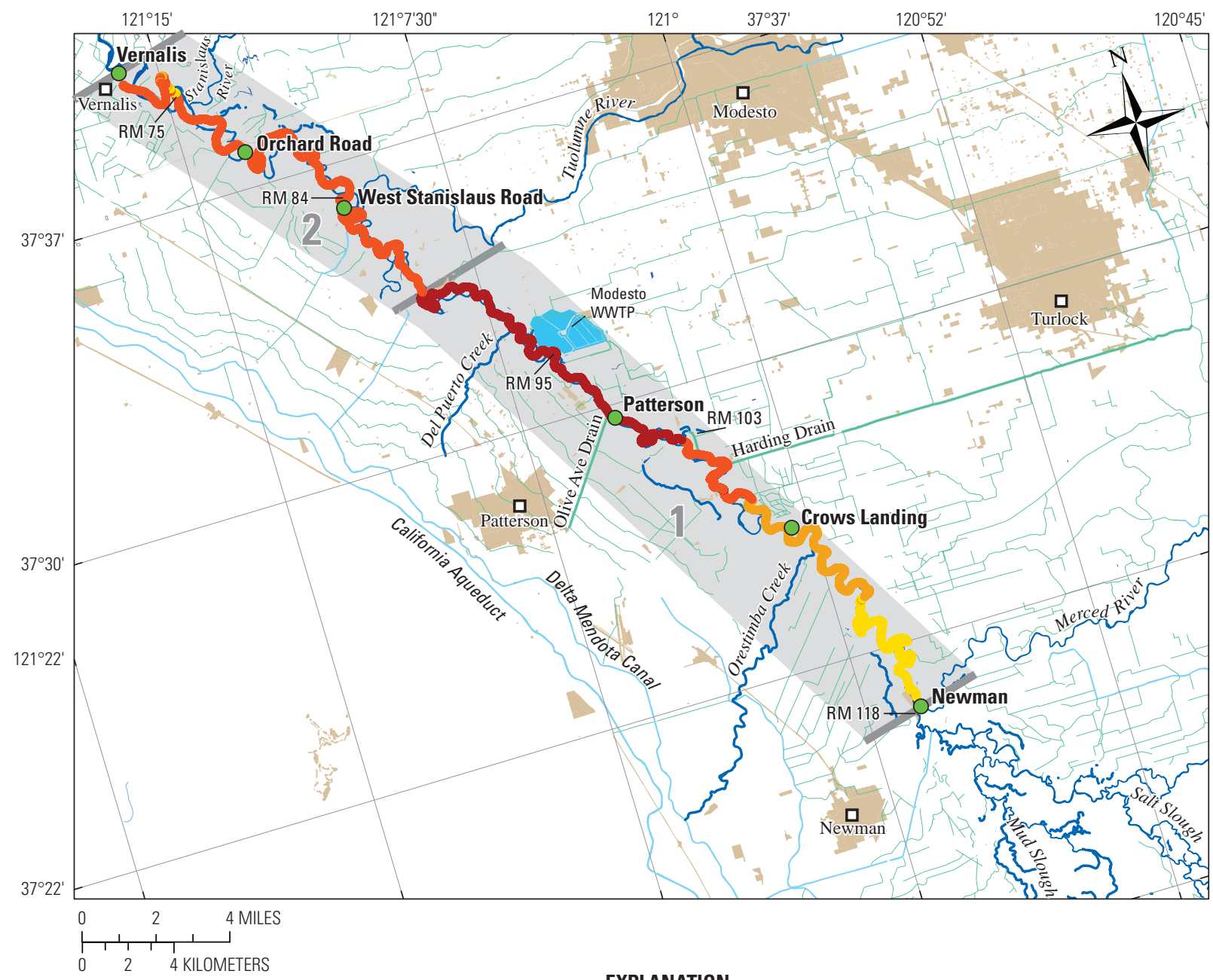

EXPLANATION

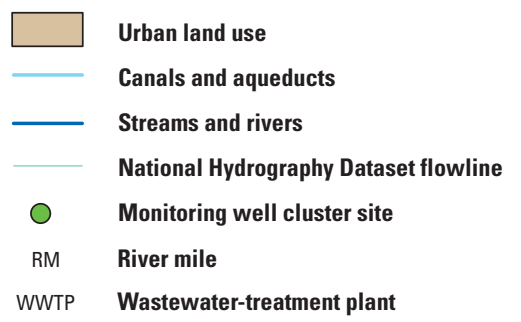

\begin{tabular}{|c|c|c|}
\hline \multicolumn{2}{|c|}{$\begin{array}{l}\text { Estimated Chlorophyll- } \alpha \\
\text { (micrograms per liter) }\end{array}$} & Sequence of continuous sampling events \\
\hline - & 0.7 to 5.7 & 1 October 15, 2008 (7am-6pm) \\
\hline - & 5.8 to 8.3 & 2 October 16, 2008 (7am-6pm) \\
\hline - & 8.4 to 10.8 & \\
\hline - & 10.9 to 58.8 & \\
\hline
\end{tabular}

Figure 71. Estimated chlorophyll- $\alpha$ concentration measurements recorded during the longitudinal profile survey over a 45-mile reach of the San Joaquin River during October 2008. 


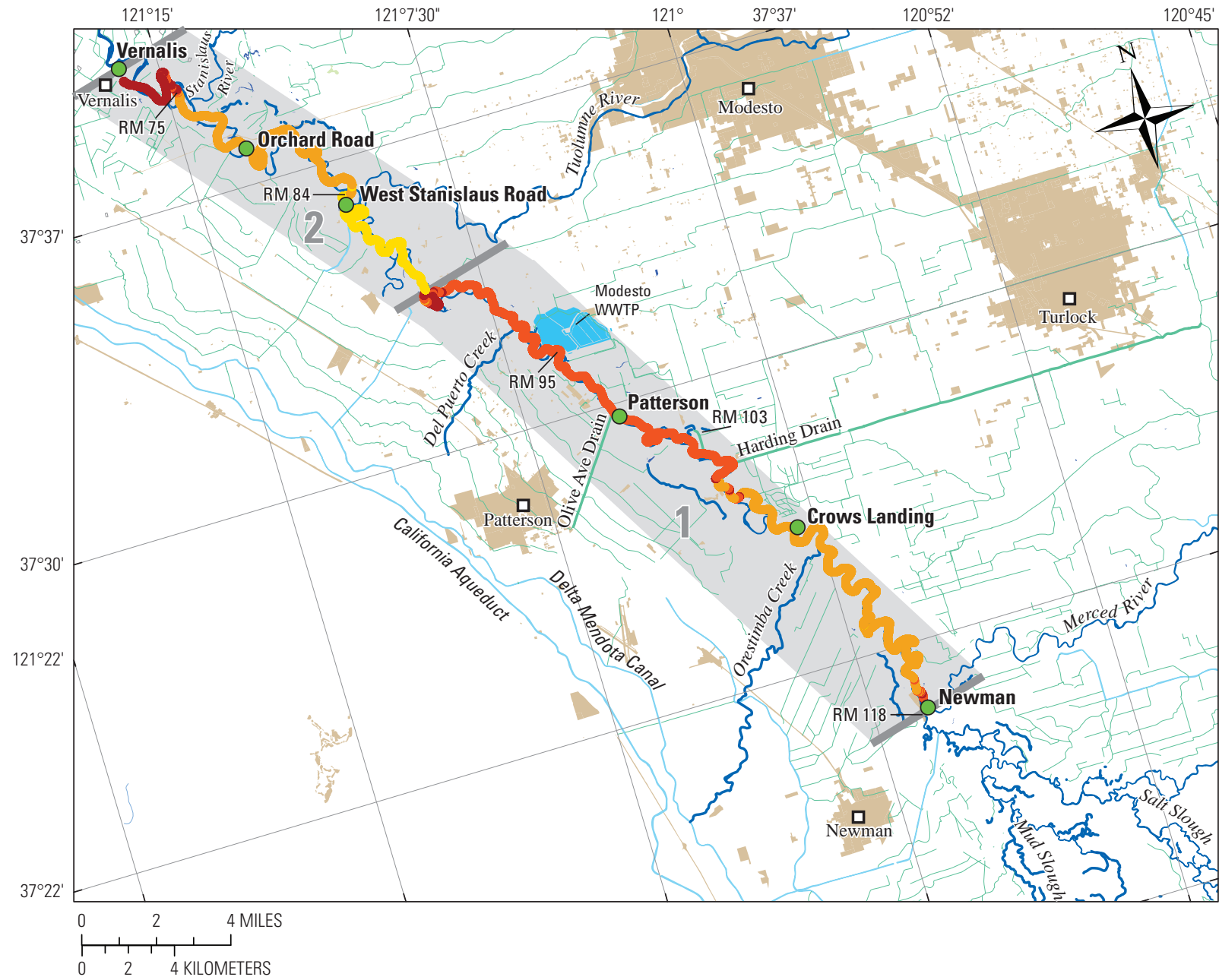

EXPLANATION

\begin{tabular}{cl}
\hline & Urban land use \\
& Canals and aqueducts \\
& Streams and rivers \\
& National Hydrography Dataset flowline \\
& Monitoring well cluster site \\
RM & River mile \\
WWTP & Wastewater-treatment plant
\end{tabular}

\begin{tabular}{|c|c|c|}
\hline \multicolumn{2}{|c|}{ DO (milligrams per liter) } & Sequence of continuous sampling events \\
\hline - & 8.2 to 8.5 & 1 October 15, 2008 (7am-6pm) \\
\hline - & 8.6 to 8.9 & 2 October 16, 2008 (7am-6pm) \\
\hline - & 9.0 to 9.3 & \\
\hline - & 9.4 to 12.7 & \\
\hline
\end{tabular}

Figure 72. Dissolved oxygen (DO) measurements recorded during the longitudinal profile survey over a 45-mile reach of the San Joaquin River during October 2008. 


\section{Estimated Loads of Dissolved Inorganic Average Dissolved Organic Carbon Nitrogen and Dissolved Organic} Carbon

Loads from groundwater to the SJR were estimated using the average concentrations of dissolved inorganic nitrogen (DIN) and dissolved organic carbon (DOC), measured during streambed Synoptics I-IV, multiplied by the average groundwater discharge rate determined using MODFLOW (table 6).

\section{Average Dissolved Inorganic Nitrogen Concentrations}

Concentrations of DIN were calculated as the sums of the concentrations of nitrate, nitrite, and ammonium in each sample. The SJR was divided into uniform stream reach lengths, and average concentrations of each nutrient were calculated for every 2.9 river miles (from river mile 131.5 to 72.0) from transects measured in all four synoptics. Stream reaches of 2.9 river miles were selected because that distance gave the greatest number of segments (20) in common to all four synoptics. This method allowed the data to be spatially normalized so that no one segment of the river would have disproportional emphasis. Deep and shallow concentrations were used in calculating the averages for each 2.9-mi stream reach, and the average for all twenty of the 2.9-mi stream reaches was calculated and is presented as follows:

\begin{tabular}{lc}
\hline \multicolumn{1}{c}{ Constituent } & $\begin{array}{c}\text { Average concentration } \\
\text { for all stream reaches } \\
\text { (milligrams per liter as nitrogen) }\end{array}$ \\
\hline Nitrate & 0.52 \\
Nitrite & 0.02 \\
Ammonium & 1.51 \\
Dissolved inorganic nitrogen & 2.05 \\
\hline
\end{tabular}

Histograms of concentrations of nitrate, nitrite, and ammonium from the shallow and deep samples for each of the four synoptic are depicted in figures 73 and 74 . The averages compiled from all of the 2.9-mi stream reaches are consistent with the most frequently observed concentrations (tallest bars in the histograms) throughout all four synoptics.

Average concentrations of DOC in groundwater discharging to the SJR were calculated in the same manner as described in the previous section for DIN. Concentrations of DOC measured at the deep and shallow depths were used in calculating the average concentrations per 2.9-mi stream reach. The average DOC concentration from all four synoptics, $2.38 \mathrm{mg} / \mathrm{L}$, was used in the load calculation.

\section{Load Calculation}

Loads are generally calculated by multiplying concentrations (mass per unit volume) by volume discharged (Q). Estimated loads were calculated by multiplying the average concentration of DIN and the average concentration of DOC as described above by $1 \mathrm{cfs} / \mathrm{mi}$, (the MODFLOW result of simulated groundwater discharge to the SJR). This rate $(1 \mathrm{cfs} / \mathrm{mi})$ was assumed to be the groundwater discharge rate to the SJR for the entire 59-mi study reach (Q was equal to $59 \mathrm{ft}^{3} / \mathrm{s}$ or $5,100,000 \mathrm{ft}^{3} /$ day). The calculation for the loads was as follows:

$$
\text { Load }\left(\frac{\text { mass }}{\text { day }}\right)=\text { Concentration }\left(\frac{\text { mass }}{\text { volume }}\right) \times \mathrm{Q}\left(\frac{\text { volume }}{\text { day }}\right)
$$

\begin{tabular}{ccc}
\hline & $\begin{array}{c}\text { Dissolved inorganic } \\
\text { nitrogen load, } \\
\text { in kilograms of nitrogen } \\
\text { per day }\end{array}$ & $\begin{array}{c}\text { Dissolved organic } \\
\text { carbon load, } \\
\text { in kilograms of carbon } \\
\text { per day }\end{array}$ \\
\hline Synoptics I-IV & 300 & 350 \\
\hline
\end{tabular}

\section{Comparison of Estimated Groundwater Loads to Surface-Water Loads at Vernalis}

Estimated loads from groundwater discharge to the SJR were compared to the sum of the average instantaneous surface-water loads for the four synoptics at the most downstream site, SJR at Vernalis stream gage (11303500, river mile 72.2). Instantaneous loads of DIN were calculated from bimonthly nutrient samples collected at Vernalis by the USGS National Water Quality Assessment (NAWQA) program (USGS NWISweb, http://waterdata.usgs.gov/ca/nwis/nwis) during September 2006 through January 2009. 

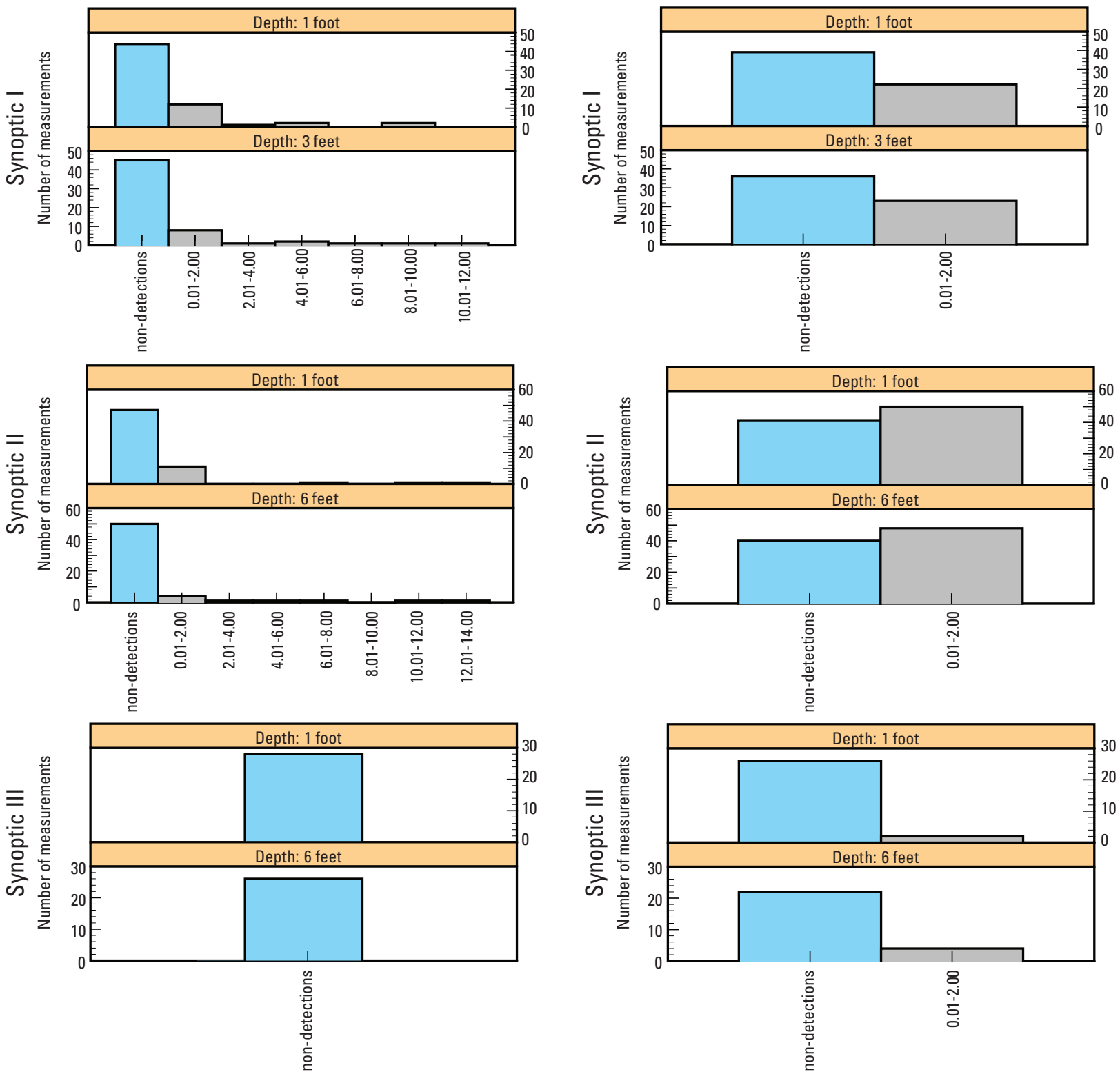

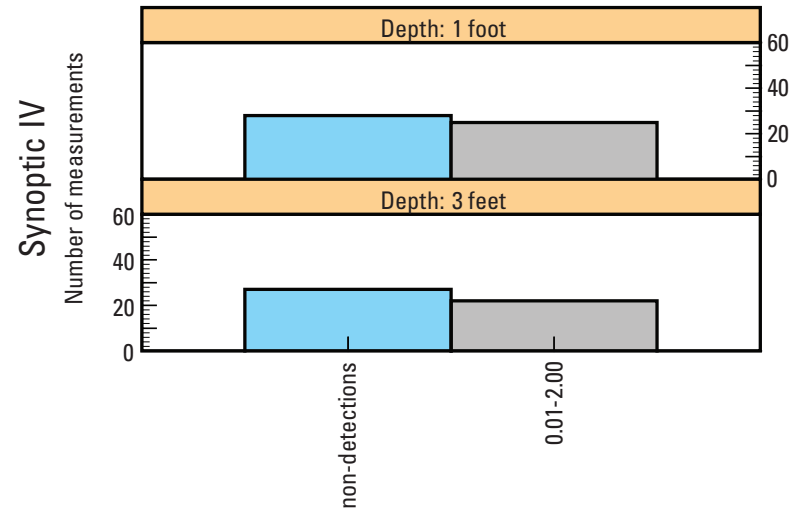

Nitrate, in milligram per liter as nitrogen

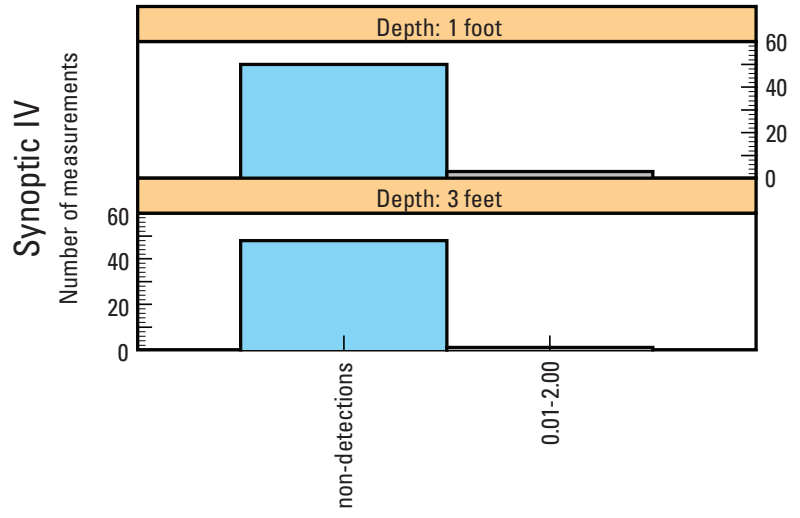

Nitrite, in milligram per liter as nitrogen

Figure 73. Distribution of nitrate and nitrite concentrations measured during Synoptics I-IV at the shallow (1 foot) and deep (3-6 feet) depths. 

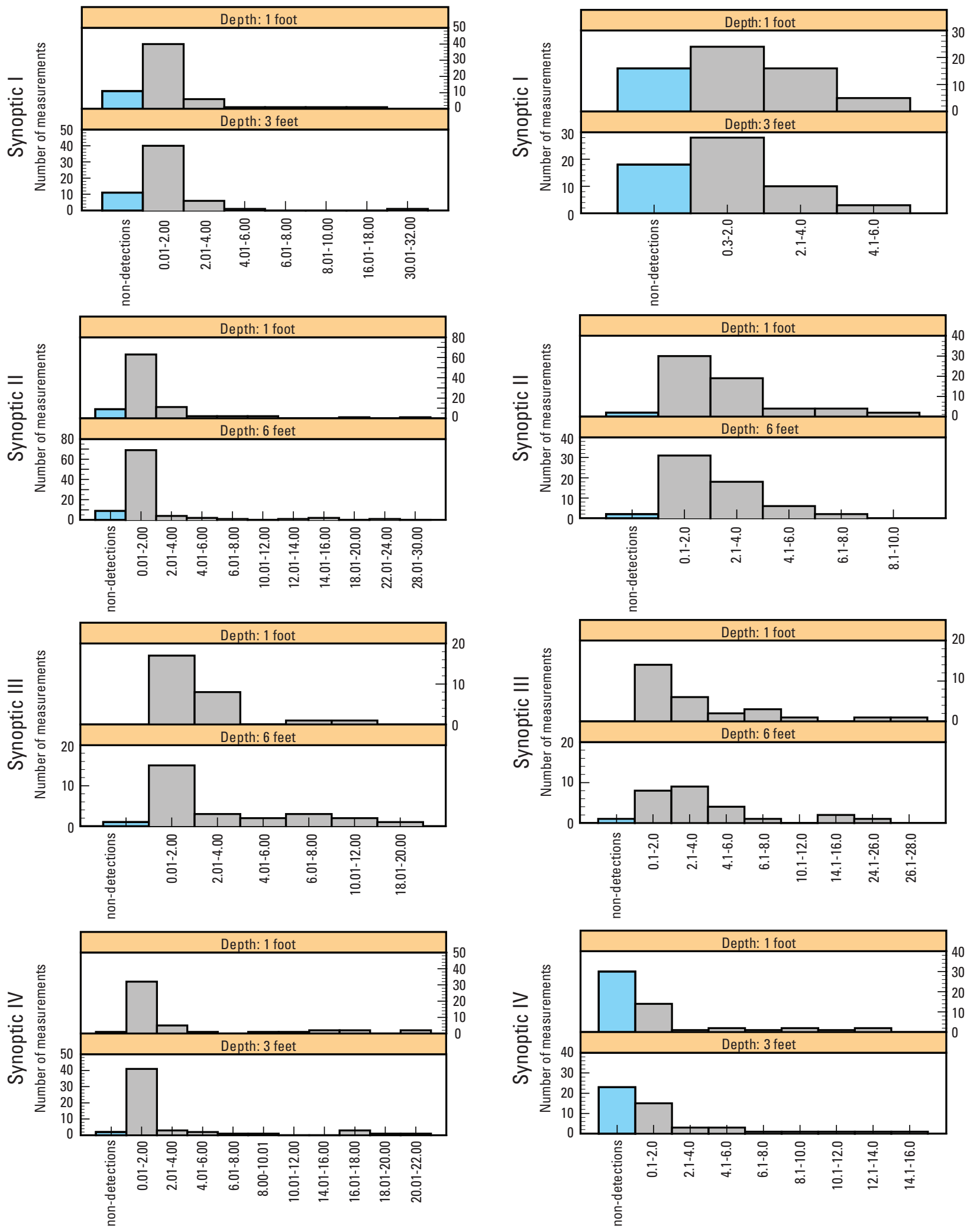

Ammonium, in milligram per liter as nitrogen

Dissolved organic carbon, in milligram per liter

Figure 74. Distribution of ammonium and dissolved organic carbon concentrations measured during Synoptics I-IV at the shallow (1 foot) and deep (3-6 feet) depths. 
Instantaneous loads of DOC were calculated from mean daily DOC concentrations reported by the California Department of Water Resources water-quality station McCun Station near Vernalis (http://cdec.water.ca.gov/cgi-progs/ staMeta?station_id=SJR) during September 2006 through January 2009. The discharge data used in the surface-water load calculations were measured at the SJR near Vernalis stream gage (11303500). Based on the instantaneous loads calculated, the load comparison is as follows:

\begin{tabular}{ccc}
\hline & $\begin{array}{c}\text { Estimated } \\
\text { groundwater } \\
\text { loads to the } \\
\text { San Joaquin River } \\
\text { (Synoptics I-IV) }\end{array}$ & $\begin{array}{c}\text { Estimated } \\
\text { instantaneous } \\
\text { surface-water loads } \\
\text { at Vernalis } \\
\text { (Synoptics I-IV) }\end{array}$ \\
\hline $\begin{array}{c}\text { Dissolved inorganic } \\
\text { nitrogen, in kilograms } \\
\text { of nitrogen per day }\end{array}$ & 300 & 3,500 \\
$\begin{array}{c}\text { Dissolved organic } \\
\text { carbon, in kilograms } \\
\text { of nitrogen per day }\end{array}$ & 350 & \\
\hline
\end{tabular}

The estimated groundwater loads to the SJR for DIN and DOC for the 59-mi study reach were approximately 9 and 7 percent, respectively, of the instantaneous surface-water loads calculated for the most downstream site, Vernalis, on the basis of groundwater data from the four synoptics. The synoptics were done during low-flow conditions, typically in late summer. Groundwater discharge rates to the SJR tend to be the same throughout the year except during high-flow events (fig. 37), in which flow reversals occur and surface water briefly recharges the groundwater. Figure 75 depicts the instantaneous surface-water loads of nitrate, nitrite, ammonium, and DOC in the SJR at the Vernalis site for the entire study period, with the synoptic periods highlighted.

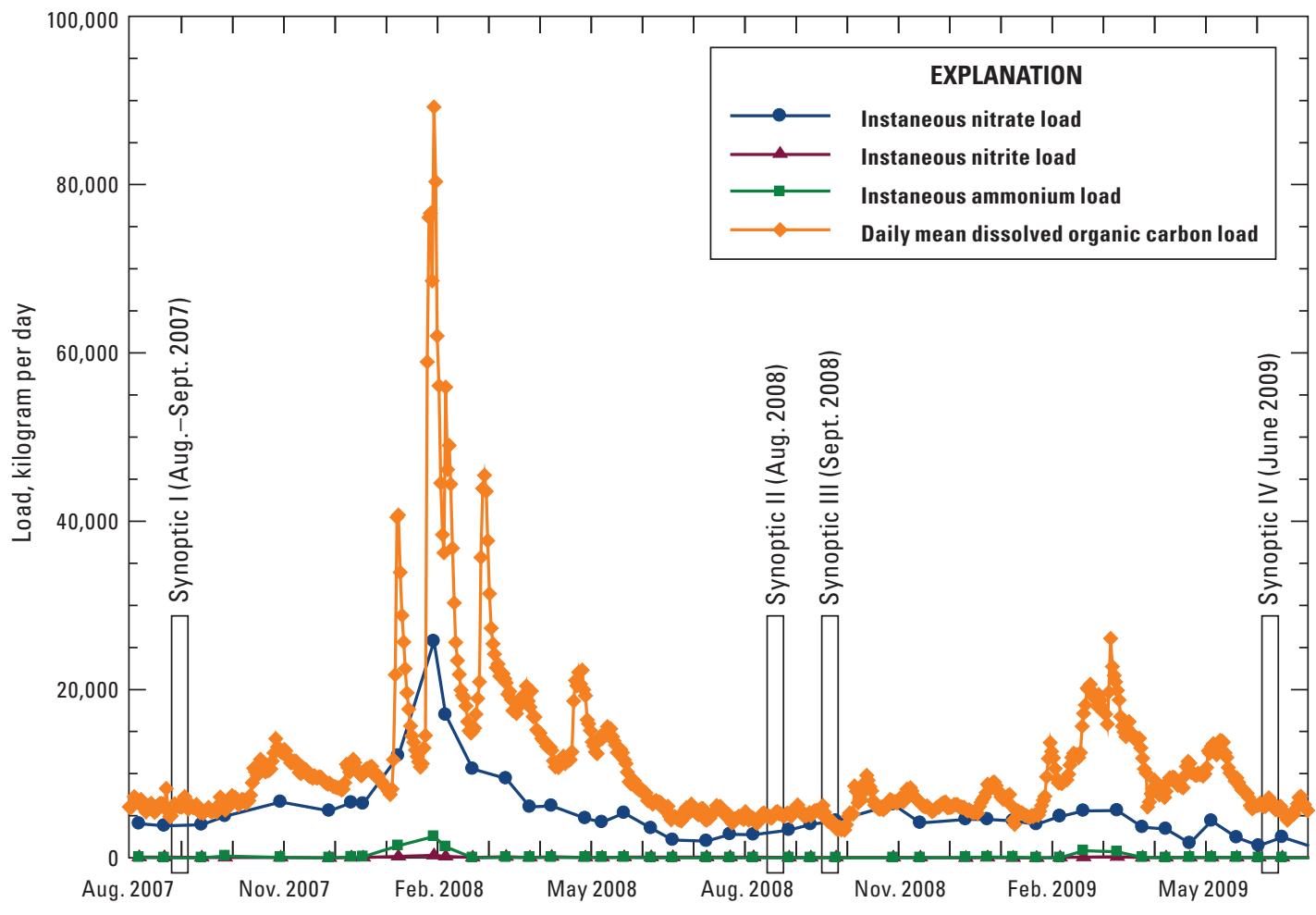

Figure 75. Instantaneous loads of nitrate, nitrite, ammonium, and dissolved organic carbon in the San Joaquin River at Vernalis that coincide with the streambed synoptic surveys (August 2007-June 2009). 


\section{Summary and Conclusions}

The primary objective of this study was to quantify the rate of groundwater discharge (in cubic feet per second per mile) to the lower SJR and its nitrate and DOC concentrations using four approaches. The four approaches-monitoring of bank wells and in-stream wells, streambed synoptic surveys, longitudinal profile surveys, and two modeling methodsprovided a combination of temporal, spatial, quantitative, qualitative evidence of groundwater contributions and their associated quality.

The SJR was found to be a gaining river in most sections of the 59-mi study reach. In addition to the upward vertical flow component, a horizontal flow component was observed predominately in the westward direction below the river. This flow direction could be the result of localized west-side pumping. When comparing the past study (Phillips and others, 1991) to the present study, the model results indicated that west-side pumping had become significant enough to create a horizontal flow reversal at the study sites. On average, the groundwater discharge rate during low flow in the SJR was found to be $1.0 \mathrm{cfs} / \mathrm{mi}$ and tended to be lower during highflow events. During high-flow events, flow-reversal can occur, when surface water briefly recharges the groundwater flow system.

Groundwater discharge was found to be a source of nutrients and DOC to the SJR, but the average concentrations in the groundwater measured during the streambed synoptic surveys (2.48 $\mathrm{mg} / \mathrm{L}$ as $\mathrm{N}$ and $2.75 \mathrm{mg} / \mathrm{L}$ as $\mathrm{C}$ ) were similar to or lower than those observed in the river itself $(2.45 \mathrm{mg} / \mathrm{L}$ as $\mathrm{N}$ and $3.90 \mathrm{mg} / \mathrm{L}$ as C). Nitrate concentration exceeded the detection limit of $0.01 \mathrm{mg} / \mathrm{L}$ as $\mathrm{N}$ in 5 percent of groundwater samples from in-stream wells analyzed as part of the synoptic surveys. In contrast, surface waters in the SJR tended to have nitrate concentrations in the $1-3 \mathrm{mg} / \mathrm{L}$ range. We conclude that a zone of lower oxygen (less than $2 \mathrm{mg} / \mathrm{L}$ ) in the streambed of the SJR could limit the amount of nitrate contributions from regional groundwater flow because nitrate can be converted within this zone to nitrogen gases. However, appreciable concentrations of ammonium (average concentration was $1.92 \mathrm{mg} / \mathrm{L}$ as $\mathrm{N}$, 95th percentile was $10.3 \mathrm{mg} / \mathrm{L}$ as $\mathrm{N}$ ), believed to originate from anoxic mineralization of streambed sediments, could contribute some nitrogen as nitrate to the overlying stream following in-stream nitrification. Dissolved organic carbon concentrations were highly variable in the shallow groundwater below the SJR, generally ranging between 1 and $5 \mathrm{mg} / \mathrm{L}$, with maximum concentrations ranging between 15 and $20 \mathrm{mg} / \mathrm{L}$. Most of the DOC concentrations tended to be slightly higher in surface waters ( $3-5 \mathrm{mg} / \mathrm{L}$ ) than in the shallow groundwater. Given that DOC concentrations in the groundwater were similar to or less than those observed in surface water, we concluded that the streambed and the riparian zone groundwater did not appreciably increase DOC concentrations in the SJR.

Water-quality samples were collected from nested monitoring wells in the streambed and on both banks along the SJR. At 17 of the 26 monitoring wells, no nitrate was detected during the monitoring period. The lack of nitrate is attributed to denitrification, which can result in the conversion of nitrate to nitrogen gases under anoxic conditions. The majority of the wells were anoxic or had very low dissolved oxygen levels (less than $2 \mathrm{mg} / \mathrm{L}$ ) throughout the study period. Ammonium concentrations were generally low (less than $1 \mathrm{mg} / \mathrm{L}$ as $\mathrm{N}$ ). DOC concentrations varied among monitoring wells, but generally ranged from 1 to $4 \mathrm{mg} / \mathrm{L}$. The 14 bank wells had been sampled once in 1988 following their original installation. With few exceptions, SC and nitrate concentrations measured in this study were virtually identical to those measured 20 years ago. The longitudinal profile surveys by boat were not particularly useful in identifying groundwater discharge areas, but proved helpful in characterizing areas influenced by surface-water inputs. We conclude that the longitudinal profile surveys described here were useful as a baseline survey, mainly for identification of tributary inflows affecting concentrations of nitrate and DOC.

Loads from groundwater to the SJR were estimated by using the average concentrations of dissolved inorganic nitrogen (DIN) and dissolved organic carbon (DOC) measured during the streambed synoptic surveys, which were done during the summer months of 2007-09, multiplied by the average groundwater discharge rate determined using MODFLOW. Groundwater discharge was found to contribute approximately 9 percent of the DIN (300 kilograms per day as $\mathrm{N}$ ) and 7 percent of the DOC load (340 kilograms per day as C) observed in the SJR at Vernalis during this study. 


\section{References Cited}

Anderson, M.P., 2005, Heat as a ground water tracer: Ground Water, v. 46, no. 6, p. 951-968.

Bird, S.M., Fram, M.S., and Crepeau, K.L., 2003, Method of analysis by the U.S. Geological Survey California District Sacramento Laboratory-Determination of dissolved organic carbon in water by high temperature catalytic oxidation, method validation, and quality-control practices: U.S. Geological Survey Open-File Report 03-366, 14 p.

Belitz, Kenneth, and Heimes, F.J., 1990, Character and evolution of the ground-water flow system in the central part of the western San Joaquin Valley, California: U.S. Geological Survey Water-Supply Paper 2348, 28 p.

Bergamaschi, B.A., Kalve, Erica, Guenther, Larry, Mendez, G.O., and Belitz, Kenneth, 2005, An assessment of optical properties of dissolved organic material as quantitative source indicators in the Santa Ana River Basin, Southern California: U.S. Geological Survey Scientific Investigations Report 2005-5152, 38 p.

Beutel, M.W., 2006, Inhibition of ammonia release from anoxic profundal sediments in lakes using hypolimnetic oxygenation: Ecological Engineering, v. 28, p. 271-279.

Brunet, R.C., and Garcia-Gil, L.J., 1996, Sulfideinduced dissimilatory nitrate reduction to ammonia in anaerobic freshwater sediments: FEMS Microbiology Ecology, v. 21, p. 131-138, available at http://dx.doi. org/10.1111/j.1574-6941.1996.tb00340.x.

Burow, K.R., Stork, S.V., and Dubrovsky, N.M., 1998, Nitrate and pesticides in ground water in the eastern San Joaquin Valley, California: occurrence and trends: U.S. Geological Survey Water-Resources Investigations Report 98-4040A, 33 p.

California Department of Water Resources, 2001, Irrigated crop area for California, 2000, accessed March 29, 2007, at http://www.water.ca.gov/landwateruse/anaglwu.cfm.

California Department of Water Resources, 2004a, Drought preparedness, hydrologic and water supply conditions: an example of water year classifications, accessed February 18, 2005, at http://www.waterplan.water.ca.gov/docs/ cwpu2009/0310final/v4c12a01_cwp2009.pdf.

California Department of Water Resources, 2004b, WSIHIST Chronological reconstructed Sacramento and San Joaquin Valley water year hydrologic classification indices, 6 p., accessed May 3, 2013, at http://www1.pacific.edu/eng/ EERP/Reports/DO\%20Task\%204_Final\%20Report_ submitted_051808.pdf.
California Department of Water Resources, 2005, The California Water Plan Update 2005: CDWR Bulletin 16005, v. 3, December 2005, Sacramento, Calif., accessed August 4, 2006, at http://www.waterplan.water.ca.gov/ previous/cwpu2005/index.cfm\#vol3.

California Regional Water Quality Control Board, Central Valley Region, 2005, Amendments to the water quality control plan for the Sacramento River and San Joaquin River Basins for the control program for factors contributing to dissolved oxygen impairment in the Stockton Deep Water Ship Channel-Final Staff Report: California Environmental Protection Agency, Rancho Cordova, Calif., 95 p., accessed June 14, 2010, at http:// www.swrcb.ca.gov/centralvalley/water_issues/tmdl/central_ valley_projects/san_joaquin_oxygen/final_staff_report/ do_tmdl_final_draft.pdf.

Chapelle, F.H., McMahon, P.B., Dubrovsky, N.M., Fuji, R.F., Oaksford, E.T., and Vroblesky, D.A., 1995, Deducing the distribution of terminal electon-accepting processes in hydrologically diverse ground-water systems: Water Resources Research, v. 31, no. 2, p. 359-371.

Chapelle, F.H., Bradley, P.M., McMahon, P.B., Kaiser, Karl, and Benner, Ron, 2012, Dissolved oxygen as an indicator of bioavailable dissolved organic carbon in groundwater: Groundwater, v. 50, no. 2, p. 230-241.

Clesceri, L.S., Greenberg, A.E., and Eaton, A.D., (eds.), 1998, Standard methods for the examination of water and wastewater, 20th ed.: American Public Health Association, American Water Works Association, and Water Environment Association, Washington, D.C.

Coble, P.G., 1996, Characterization of marine and terrestrial DOM in seawater using excitation-emission matrix spectroscopy. Marine Chemistry, v. 51, no. 4, p. 325-346.

Constantz, Jim, 2008, Heat as a tracer to determine streambed water exchanges: Water Resources Research, v. 44, W00D10, available at http://dx.doi. org/10.1029/2008WR006996.

Davis, G.H., Green, J.H., Olmstead, F.H., and Brown, D.W., 1959, Ground-water conditions and storage capacity in the San Joaquin Valley, California: U.S. Geological Survey Water-Supply Paper 1618, 125 p.

Davis, S.N., and Hall, F.R., 1959, Water quality of eastern Stanislaus and northern Merced Counties, California: Stanford University Publications, Geological Sciences, v. 6, no. 1,112 p.

Doane, T.A., and Horwath, W.R., 2003, Spectrophotometric determination of nitrate with a single reagent: Analytical Letters, v. 36, no. 12, p. 2713-2722. 
Domagalski, J.L., Phillips, S.P., Bayless, E.R., Zamora, Celia, Kendall, Carol, Wildman, R.A., and Hering, J.G., 2008, Influences of the unsaturated, saturated, and riparian zones on the transport of nitrate near the Merced River, California, USA: Hydrogeology Journal, v. 16, p. 675-690.

Downing, B.D., Boss, Emmanuel, Bergamaschi, B.A., Fleck, J.A., Lionberger, M.A., Ganju, N.K., Shoellhamer, David, and Fujii, Roger, 2009, Quantifying fluxes and characterizing compositional changes of dissolved organic matter in aquatic systems in situ using combined acoustic and optical measurements: Limnology and Oceanography: Methods, v. 7, p. 119131, available at https://profile.usgs.gov/myscience/ upload_folder/ci2011Aug0620165720370DOWNING\%20 Quantifying\%20fluxes\%20and\%20characterizing\%20 compositional\%20changes\%20of\%20\%20DOM\%20in\%20 aquatic\%20systems.pdf.

Draper, A.J., Munevar, A., Arora, S.K., Reyes, E., Parker, N.L., Chung, F.I., and Peterson, L.E., 2004, CalSim: Generalized model for reservoir system analysis: ASCE Journal of Water Resources Planning and Management, v. 130, no. 6, p. 480-489, doi:10.1061/(ASCE)07339496(2004)130:6(480), available at http://dx.doi. org/10.1061/(ASCE)0733-9496(2004)130:6(480).

Edwards, T.K., and Glysson, G.D., 1999, Field methods for measurement of fluvial sediment: U.S. Geological Survey Techniques of Water-Resources Investigations, book 3, chap. C2, 89 p.

Essaid, H.I., Zamora, Celia, McCarthy, K.A., Vogel, J.A., and Wilson, J.R., 2008, Using heat to characterize streambed water flux variability in four stream reaches: Journal of Environmental Quality, v. 37, no. 3, p. 1010-1023.

Farrar, C.D., and Bertoldi, G.L., 1988, Region 4, Central Valley and Pacific Coast Ranges, in Back, William, Rosenshein, J.S., and Seaber, P.R., eds., Hydrogeology: Boulder, Colo., Geological Society of America, Geology of North America, v. O-2, p. 59-67.

Faunt, C.C., ed., 2009, Groundwater availability of the Central Valley Aquifer, California: U.S. Geological Survey Professional Paper 1766, 225 p.

Findlay, S., Quinn, J.M., Hickey, C.W., Burrell, Greg, and Downes, Malcolm, 2001, Effects of land use and riparian flowpath on delivery of dissolved organic carbon to streams: Limnology and Oceanograhy, v. 46, no. 2, p. 345-355.

Forster, J.C., 1995, Soil nitrogen, in Alef, K., and Nannipieri, P., eds., Methods in applied soil microbiology and biochemistry: Salt Lake City, Utah, Academic Press, p. 79-87.
Grober, L.F., Kavvas, M.L., Rashmawi, E.A., Grismer, M.E., and Kratzer, C.R., 1992, Stochastic water quality modeling and numerical groundwater simulation for the lower San Joaquin River basin: Report to State Water Resources Control Board from University of California, Davis, 128 p.

Gronberg, J.M., Dubrovsky, N.M., Kratzer, C.R., Domagalski, J.L., Brown, L.R., and Burow, K.R., 1998, Environmental setting of the San Joaquin-Tulare Basins, California: U.S. Geological Survey Water-Resources Investigations Report 97-4205, 45 p.

Gu, Q., and Kenny, J.E., 2009, Improvement of inner filter effect correction based on determination of effective geometric parameters using a conventional fluorimeter: Analytical Chemistry, v. 81, no. 1, p. 420-426.

Hallock, R.J., Elwell, R.F., and Fry, D.H., Jr., 1970, Migrations of adult king salmon Oncorhynchus tshawytscha in the San Joaquin delta, as demonstrated by the use of sonic tags: State of California Department of Fish and Game, Fish Bulletin 151, 92 p.

Harbaugh, A.W., Banta, E.R., Hill, M.C., and McDonald, M.G., 2000, MODFLOW-2000, the U.S. Geological Survey modular ground-water modelUser guide to modularization concepts and the groundwater flow process: U.S. Geological Survey Open-File Report 00-92, 121 p.

Harvey, F.E., Lee, D.R., Rudolph, D.L., and Frape, S.K., 1997, Locating groundwater discharge in large lakes using bottom sediment electrical conductivity mapping: Water Resources Research, v. 33, no. 11, p. 2609-2615.

Healy, R.W., and Ronan, A.D., 1996, Documentation of computer program VS2DH for simulation of energy transport in variably saturated porous media-modification of the U.S. Geological Survey's computer program VS2DI: U.S. Geological Survey Water-Resources Investigations Report 96-4230, 36 p.

Helsel, D.R., and Hirsch, R.M., 1992, Statistical methods in water resources: Amsterdam, The Netherlands, Elsevier, 522 p.

Hsieh, P.A., Wingle, W., and Healy, R.W., 2000, VS2DI-a graphical software package for simulating fluid flow and solute or energy transport in variably saturated porous media: U.S. Geological Survey Water-Resources Investigations Report 99-4130, 16 p.

Jaffe, R., McKnight, D.M., Maie, N., Cory, R., McDowell, W.H., and Campbell, J.L., 2008, Spatial and temporal variations in DOM composition in ecosystems: The importance of long-term monitoring of optical properties: Journal of Geophysical Research, v. 113, G04032, available at http://www.agu.org/pubs/ crossref/2008/2008JG000683.shtml. 
Johnson, A.I., Moston, R.P., and Morris, D.A., 1968, Physical and hydrological properties of water-bearing deposits in subsiding areas in central California: U.S. Geological Survey Professional Paper 497-A, 71 p.

Jurgens, B.C., Burow, K.R., Dalgish, B.A., and Shelton J.L, 2008, Hydrogeology, water chemistry, and factors affecting the transport of contaminants of a public-supply well in Modesto, eastern San Joaquin Valley, California: U.S. Geological Survey Scientific Investigations Report 2008-5156, 78 p., available at http://pubs.usgs.gov/ sir/2008/5156/.

Korom, S.F., 1992, Natural denitrification in the saturated zone: A review: Water Resources Research, v. 28, no. 6, p. 1657-1668, available at http://www.agu.org/pubs/ crossref/1992/92WR00252.shtml.

Krasner, S.W., Weinberg, H.S., Richardson, S.D., Pastor, S.J., Russell Chinn, Sclimenti, M.J., Onstad, G.D., and Thruston, A.D, 2006, Occurrence of a new generation of disinfection byproducts: Environmental Science \& Technology, v. 40, no. 23, p. 7175-7185, available at http:// pubs.acs.org/doi/abs/10.1021/es060353j.

Kratzer, C.R., Dileanis, P.D., Zamora, C., Silva, S.R., Kendall, C., Bergamaschi, B.A., and Dahlgren, R.A., 2004, Sources and transport of nutrients, organic carbon, and chlorophyll- $\alpha$ in the San Joaquin River, California, during summer and fall, 2000 and 2001: U.S. Geological Survey Water-Resources Investigations Report 03-4127, 113 p.

Kratzer, C.R., and Biagtan, R.N., 1997, Determination of traveltimes in the lower San Joaquin River basin, California, from dye-tracer studies during 1994-1995: U.S. Geological Survey Water-Resources Investigations Report 97-4018, $20 \mathrm{p}$.

Kratzer, C.R., and Shelton, J.L., 1998, Water quality assessment of the San Joaquin-Tulare basins, California: Analysis of available data on nutrients and suspended sediment in surface water, 1972-1990: U.S. Geological Survey Professional Paper 1587, 92 p.

Kratzer, C.R., Pickett, P.J., Rashmawi, E.A., Cross, C.L., and Bergeron, K.D., 1987, An input-output model of the San Joaquin River from the Lander Avenue bridge to the Airport Way bridge, appendix C of San Joaquin River Basin Technical Committee Report: Regulation of agricultural drainage to the San Joaquin River: California State Water Resources Control Board Order WQ 85-1, 173 p.

Kratzer, C.R., Kent, R.H., Saleh, D.K., Knifong, D.L., Dileanis, P.D., and Orlando, J.L., 2010, Trends in nutrient concentrations, loads, and yields in streams in the Sacramento, San Joaquin, and Santa Ana basins, California, 1975-2004: U.S. Geological Survey Scientific Investigations Report 2010-5228, 112 p., available at http:// pubs.usgs.gov/sir/2010/5228/.
Lai, D.Y.F., and Lam, K.C., 2008, Phosphorus retention and release by sediments in the eutrophic Mai Po Marshes, Hong Kong: Marine Pollution Bulletin, v. 57 (6-12), p. 349-356.

Landon, M.K., Belitz, Kenneth, Jurgens, B.C., Kulongoski, J.T., and Johnson, T.D., 2010, Status and understanding of groundwater quality in the CentralEastside San Joaquin Basin, 2006: California GAMA Priority Basin project: U.S. Geological Survey Scientific Investigations Report 2009-5266, 97 p.

Landon, M.K., Green, C.T., Belitz, K., Singleton, M.J., and Esser, B.K., 2011, Relations of hydrogeologic factors, groundwater reduction-oxidation conditions, and temporal and spatial distributions of nitrate, central-eastside San Joaquin Valley, California, USA: Hydrogeology Journal, v. 19 , no. 6 , p. 1203-1224.

Lee, D.R., 1985, Method for locating sediment anomalies in lakebeds that can be caused by groundwater flow: Journal of Hydrology, v. 79, p. 187-193.

Letey, J., Williams, C.F., and Alemi, M., 2002, Salinity, drainage and selenium problems in the western San Joaquin Valley of California: Irrigation and Drainage Systems, v. 16, no.4, p. 253-259.

National Center for Atmospheric Research, 2003, DAYMET climate data, average precipitation and temperature data for 1980-97: accessed February 7, 2006, at http://www.crwr. utexas.edu/gis/gishydro05/Time/daymet.htm.

Page, R.W, 1986, Geology of the fresh ground-water basin of the Central Valley, California, with texture maps and sections: U.S. Geological Survey Professional Paper 1401C, 54 p., 5 pls. in pocket.

Page, R.W., and Bertoldi, G.L., 1983, A Pleistocene diatomaceous clay and pumiceous ash: California Geology, v. 36, no.1, p. 14-20.

Phillips, S.P., Beard, S., and Gilliom, R.J., 1991, Quantity and quality of ground-water inflow to the San Joaquin River, California: U.S. Geological Survey Water-Resources Investigations Report 91-4019, 64 p.

Phillips, S.P., and Belitz, Kenneth, 1990, Calibration of a texture-based model of ground-water flow system, western San Joaquin Valley, California: U.S. Geological Survey Open-File Report 90-573, 30 p.

Planert, Michael, and Williams, J.S., 1995, Ground water atlas of the United States: Segment 1, California, Nevada: U.S. Geological Survey Hydrologic Atlas 730-B, 1 atlas, $28 \mathrm{p}$. 
Quinn, N.W.T., and Tulloch, Alice, 2002, San Joaquin River diversion data assimilation, drainage estimation, and installation of diversion monitoring stations: Report to CALFED Bay-Delta Program on project RP-01-N61-02, September 15, 2002, Sacramento, Calif., 55 p. plus apps. A-K., available at http://www.sjrdotmdl.org/concept_ model/phys-chem_model/documents/300001039.pdf.

Rantz, S.E., 1969, Mean annual precipitation in the California region: U.S. Geological Survey Open-File Map (Reprinted 1972, 1975) by the USGS at http://water.usgs.gov/software/ NFF/manual/ca/.

Richardson, S.D., Plewa, M.J., Wagner, E.D., Shoeny, Rita, and DeMarini, D.M., 2007, Occurrence, genotoxicity, and carcinogenicity of regulated and emerging disinfection by-products in drinking water: A review and roadmap for research: Mutation Research 636, p. 178-242.

San Joaquin Valley Drainage Program, 2009, A Management Plan for Agricultural Subsurface Drainage and Related Problems on the Westside San Joaquin Valley. Final Report 1990. p.183, available at http://www.swrcb.ca.gov/ rwqcb5/water_issues/salinity/library_reports_programs/ rainbow_rpt.pdf.

Schoups, Gerrit, Hopmans, J.W., Young, C.A., Vrugt, J.A., Wallender, W.W., Tanji, K.K., and Panday, Sorab, 2005, Sustainability of irrigated agriculture in the San Joaquin Valley, California: Proceedings of National Academy of Sciences of the United States of America, v. 102, no. 43, p. 15352-15356, available at http://www.pnas.org/ content/102/43/15352.

Silliman, S.E., and Booth, D.F., 1993, Analysis of time-series measurements of sediment temperature for identification of gaining compared to losing portions of Juday Creek, Indiana: Journal of Hydrology, v. 146, p. 131-148.

Silliman, S.E., Ramirez, J., and McCabe, R.L., 1995, Quantifying downflow through creek sediments using temperature time series-one-dimensional solution incorporating measured surface temperature: Journal of Hydrology, v. 167, p. 99-119.

Stonestrom, D.A., and Constantz, Jim, eds., 2003, Heat as a tool for studying the movement of ground water near streams: U.S. Geological Survey Circular 1260, 96 p.

Stringfellow, William, Borglin, Sharon, Hanlon, Jeremy, Graham, Justin, Dahlgren, Randy, Burkes, Remie, Spier, Chelsea, Letain, Tracy, Hutchison, Kethleen, and Granadosin, Arlene, 2008, San Joaquin River upstream DO TMDL project, ERP-02D-P63, task 4: monitoring study, final task report, May 2008: San Joaquin Valley Drainage Authority, appendix F (summary of flow data), p. 437-557, accessed September 3, 2009, at http://www1.pacific.edu/ eng/EERP/Reports/DO\%20Task\%204_Final\%20Report_ submitted_051808.pdf.
U.S. Census Bureau, 2001a, Census 2000 State and County QuickFacts, California, revised January 2007, accessed March 29, 2007, at http://quickfacts.census.gov/qfd/ states/06000.html.

U.S. Census Bureau, 2001b, Census 2000 State and County QuickFacts, Mariposa County, revised June 2006, accessed October 5, 2006, at http://quickfacts.census.gov/qfd/ states/06/06043.html.

U.S. Census Bureau, 2001c, Census 2000 State and County QuickFacts, Merced County, revised June 2006, accessed October 5, 2006, at http://quickfacts.census.gov/qfd/ states/06/06047.html.

U.S. Census Bureau, 2001d, Census 2000 State and County QuickFacts, Stanislaus County, revised June 2006, accessed October 5, 2006, at http://quickfacts.census.gov/qfd/ states/06/06099.html.

U.S. Census Bureau, 2001e, Census 2000 State and County QuickFacts, Tuolumne County, revised June 2006, accessed October 5, 2006, at http://quickfacts.census.gov/qfd/ states/06/06109.html.

U.S. Environmental Protection Agency, 2000, Proceedings of the ground-water/surface-water interactions workshop: sponsored by USEPA's Office of Solid Waste and Emergency Response, January 1999 in Denver, Colo. ("sediment probes" or "drag probes" discussed as methods of qualitatively determining ground water "hot spots" in papers by David R. Lee p. 35-38; Thomas C. Winter and Joseph Dlugosz p. 46-53; and Allen Burton and Ned Black p. 54-57). Report available on-line at: http://www.clu-in. org/s.focus/c/pub/i/600/.

U.S. Geological Survey, 2006, Collection of water samples (ver. 2.0): U.S. Geological Survey Techniques of Water-Resources Investigations, book 9, chap. A4, September 2006, accessed November 30, 2009, at http:// pubs.water.usgs.gov/twri9A4/.

Vaccaro, J.J., and Maloy, K.J., 2006, A thermal profile method to identify potential ground-water discharge areas and preferred salmonid habitats for long river reaches: U.S. Geological Survey Scientific Investigations Report 2006-5136, 16 p.

Water Resources and Information Management Engineering, Inc., 2003, Integrated groundwater and surface water model (IGSM) user’s manual: May 2003, Sacramento, Calif., variously paginated.

Weishaar, J.L., Aiken, G.R., Bergamaschi, B.A., Fram, M.S., Fujii R., and Mopper, K, 2003, Evaluation of specific ultraviolet absorbance as an indicator of the chemical composition and reactivity of dissolved organic carbon: Environmental Science \& Technology, v. 37, p. 4702-4708. 
Winter, T.C., LaBaugh, J.W., and Rosenberry, D.O., 1988, The design and use of a hydraulic potentiomanometer for direct measurement of differences in hydraulic head between groundwater and surface water: Limnology and Oceanography, v. 33, no. 5, p. 1209-1214.

Zaugg, S.D., Smith, S.G., Schroeder, M.P., Barber, L.B., and Burkhardt, M.R., 2007, Methods of analysis by the U.S. Geological Survey National Water Quality Laboratory-Determination of wastewater compounds by polystyrene-divinylbenzene solid-phase extraction and capillary-column gas chromatography/mass spectrometry: U.S. Geological Survey Water-Resources Investigations Report 01-4186, 37 p.

Zhang, T., and Dahlgren, R.A., 2009, Nitrogen transformations in sediments of San Joaquin River, California, American Geophysical Union, 90(54), Fall Meeting, Suppl., [abs] B13C-0528, available at http://www.agu.org/meetings/ fm09/fm09-sessions/fm09_B13C.html. Full text is not available. 


\section{Appendix 1. Laboratory Methods}

\section{Appendix 1-1. Methods for University of California at Davis, Land, Air, and Water Research (LAWR) Laboratory}

Samples were analyzed for nutrients following filtration through a $0.2-\mu \mathrm{m}$ polycarbonate membrane (Millipore) in the Dahlgren laboratory for quantification of nitrate as nitrogen $\left(\mathrm{NO}_{3}-\mathrm{N}\right)$, nitrite- $\mathrm{N}\left(\mathrm{NO}_{2}-\mathrm{N}\right)$, and ammonium $\left(\mathrm{NH}_{4}-\mathrm{N}\right)$. The vanadium chloride method was used to spectroscopically determine $\mathrm{NO}_{3}^{-}+\mathrm{NO}_{2}^{-}-\mathrm{N}$ and $\mathrm{NO}_{2}^{-}-\mathrm{N}$; however, the $\mathrm{VCl}_{3}$ was not added for determination of $\mathrm{NO}_{2}^{-}-\mathrm{N}$ (MDL is $0.01 \mathrm{mg} / \mathrm{L}$; MDL, method detection limit; mg/L, milligrams per liter; Doane and Horwath, 2003). The $\mathrm{NO}_{3}-\mathrm{N}$ was calculated as difference as follows: $\mathrm{NO}_{3}$ plus $\mathrm{NO}_{2}-\mathrm{N}$ minus $\mathrm{NO}_{2}-\mathrm{N}$. The $\mathrm{NH}_{4}^{+}-\mathrm{N}$ concentration was determined spectroscopically with the Berthelot reaction, using a salicylate analog of indophenol blue (limit of detection, LOD, about 10 micrograms per liter; Forster, 1995). DOC was measured using a Dohrmann UV/ persulfate TOC analyzer (EPA Standard Method 5310C; Phoenix 8000; LOD about $0.1 \mathrm{mg} / \mathrm{L}$ ). Although the UC Davis LAWR laboratory analyzed samples for DOC, nutrients, major ions, soluble reactive phosphate and boron, only nitrate, ammonium, and DOC are presented in the report.

\section{Appendix 1-2. Methods for USGS Sacramento Organic Carbon Laboratory}

DOC concentration was measured using hightemperature catalytic oxidation with a Shimadzu TOC-V CSH total organic carbon analyzer capable of measuring nonpurgeable organic carbon (Bird and others, 2003). The mean of three to five injections was calculated for every sample and precision, described as a coefficient of variance (CV), was less than 2 percent for the replicate injections. The absorption spectra was measured between 200 and 750 nanometers on filtered samples at constant temperature $\left(25^{\circ} \mathrm{C}\right)$ with a Cary300 spectrophotometer using a $10-\mathrm{cm}$ quartz cell and distilled water as a blank.

Excitation Emission Matrix spectra (EEMs) were measured on filtered samples with a SPEX Fluoromax-4 spectrofluorometer (Horiba Jobin Yvon, Edison, N.J.) using a 150-watt xenon lamp. Fluorescence intensity was measured at excitation wavelengths of $240-440 \mathrm{~nm}$ at $10-\mathrm{nm}$ intervals, and emission wavelengths of 290-600 at 5-nm intervals on room temperature samples $\left(25^{\circ} \mathrm{C}\right)$ in a 1 -cm quartz cell. Lamp and water-Raman checks were performed daily per the manufacturer's specifications. EEMs were blank-corrected in MATLAB (MATLAB, 2008, The MathWorks, Natick, Massachusetts) to remove Raman scattering and normalized to the daily Raman peak area; Rayleigh scatter lines were removed after blank correction. Instrument bias was corrected by using the manufacturer's supplied excitation and emission correction factors. Inner filter corrections were applied to EEMs with absorbance at $254 \mathrm{~nm}$ greater than 0.03 (1-cm cuvette or $6.9 \mathrm{~m}^{-1}$ ) as described by Gu and Kenny (2009). 


\section{Appendix 2. Laboratory Quality-Control Results}

\section{Appendix 2-1. Laboratory replicates of environmental samples done by the Land, Air, and Water Resources Laboratory (LAWR) at the University of California at Davis.}

[Variability between laboratory replicates is expressed in relative percentage difference (RPD) between replicate analyses of the same environmental sample. Only samples with detections for both analyses are included in the statistical summary. Abbreviations: <, less than; =, equal]

$\begin{array}{ccc}\text { Nitrate } & \begin{array}{c}\text { Ammonium } \\ \text { (total count }=375)\end{array} & \begin{array}{c}\text { Dissolved } \\ \text { (total count }=439)\end{array} \\ \begin{array}{c}\text { organic carbon } \\ \text { (total count }=239)\end{array}\end{array}$

Laboratory reporting limit in $\mathrm{mg} / \mathrm{L}$

Number of pairs with non-detections for both analyses

Number of pairs with non-detection for one analysis and detection for the other analysis

Number of pairs with detections for both analyses

Minimum RPD

25th percentile

Median RPD

75th percentile

Maximum RPD

$\begin{array}{ccc}0.01 & 0.01 & 0.10 \\ 123 & 58 & 10 \\ { }^{1} 1 & 15 & 0 \\ & & \\ 251 & 376 & 229 \\ <0.1 & <0.1 & <0.1 \\ <0.1 & <0.1 & 0.96 \\ 0.5 & 0.6 & 2.4 \\ 1.42 & 1.75 & 4.87 \\ { }^{2} 15.4 & 327.5 & 418.9\end{array}$

${ }^{1}$ The sample detected in the replicate pair was at or just above the laboratory reporting limit.

${ }^{2}$ The maximum RPD for nitrate was associated with one sample collected on February 13, 2008, at in-stream well VRD.

${ }^{3}$ The maximum RPD for ammonium was associated with one sample collected on July 18, 2008, at in-stream well ORS.

${ }^{4}$ The maximum RPD for dissolved organic carbon was associated with one sample collected during Synoptic IV, river mile 125.8, middle of transect, 3-foot depth.

\section{Appendix 2-2. Laboratory spikes done by the Land, Air, and Water Resources Laboratory (LAWR) at the University of California at Davis.}

[Spike results are expressed as percentage recovery ( $\% \mathrm{R})$, with 100 percent being complete recovery]

\begin{tabular}{lccc}
\hline & Nitrate & Ammonium & $\begin{array}{c}\text { Dissolved } \\
\text { organic carbon }\end{array}$ \\
\hline Count & 127 & 141 & 31 \\
Minimum \%R & 93.2 & 87.5 & 90.2 \\
25th percentile \%R & 99.20 & 98.50 & 95.20 \\
Median \%R & 100.7 & 100.6 & 98.1 \\
75th percentile \%R & 102.8 & 103.6 & 104.2 \\
Maximum \%R & 112.3 & 111.1 & 107.8 \\
\hline
\end{tabular}




\section{Appendix 3. Data-Quality Objectives (D00s) for field measurements and laboratory analyses.}

[Abbreviations: abs, absorbance; DOC, dissolved organic carbon; UV, ultra violet; N, nitrogen; P, phosphorus; MDL, method detection limit; mg/L, milligrams per liter; mS/cm, millisiemens per centimeter; nm nanometer; ppb, parts per billion; ppm; parts per million; -, not available; ${ }^{\circ} \mathrm{C}$, degrees Celsius; \pm , plus or minus; percent, percent; USGS, U.S. Gelogical Survey; UC Davis LAWR, University of California at Davis, Land, Air, and Water Resources]

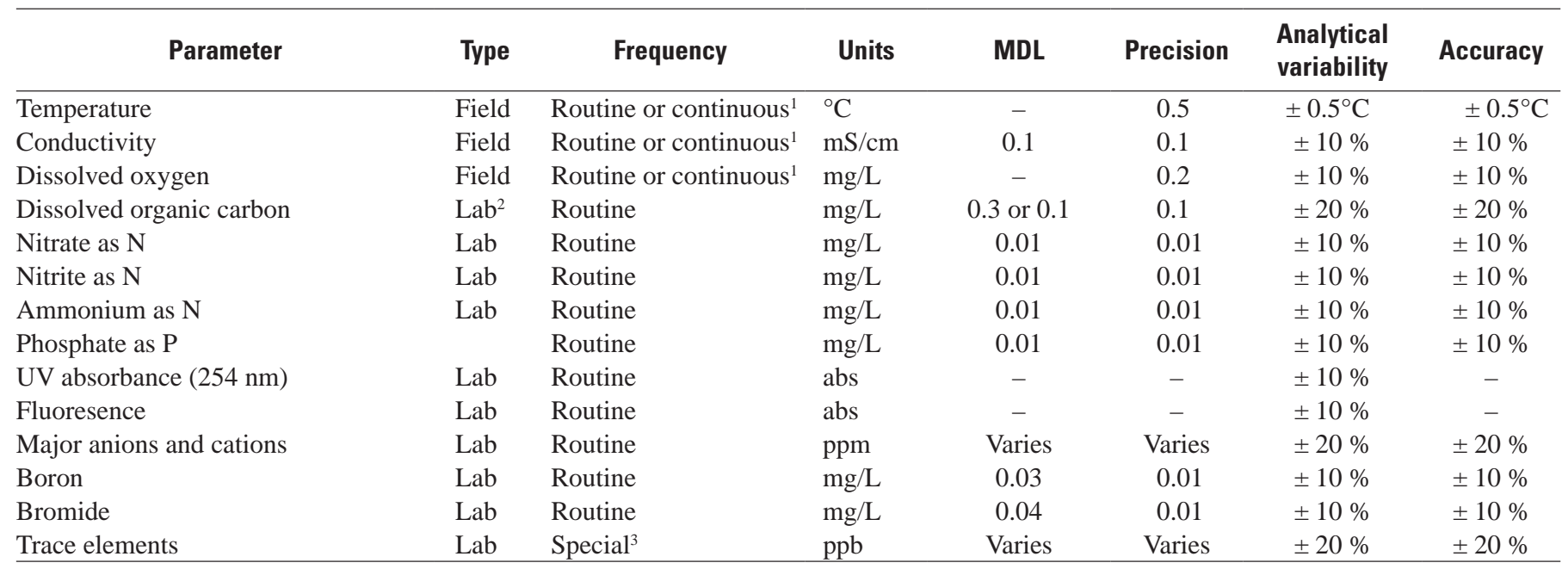

${ }^{1}$ Routine sampling frequency is defined as samples collected on an approximate monthly schedule from the monitoring wells (bank wells and in-stream wells) or from the streambed synoptic sampling events I-IV. Continuous sampling frequency is defined as measurements made during the continuous, longitudinal profile surveys.

${ }^{2}$ Dissolved organic carbon (DOC) samples were analyzed by two laboratories during the study period and, therefore, result in two MDLs. Samples analyzed by the USGS Sacramento Carbon Laboratory from September 2006 to June 2008 have an MDL of $0.3 \mathrm{mg} / \mathrm{L}$. Samples analyzed by the UC Davis LAWR Laboratory from July 2008 to January 2009 have an MDL of $0.1 \mathrm{mg} / \mathrm{L}$

${ }^{3}$ Trace Elements were analyzed by the UC Davis ICPMS Laboratory on an approximate quarterly basis. Contact information for requesting these data is provided on the project Website, http://ca.water.usgs.gov/sanj/RSgwnitrate.html, because these data are not available on the USGS National Water Information System (NWIS) or presented in appendixes 4-8. 
Appendix 4. Water-quality data results collected from bank and in-stream monitoring wells along the 59-mile study reach of the San Joaquin River, Calif. (September 2006-January 2009).

Appendix 5. Water-quality data results collected from the San Joaquin River, Calif., during Synoptic I (August-September 2007).

Appendix 6. Water-quality data results collected from the San Joaquin River, Calif., during Synoptic II (August 2008).

Appendix 7. Water-quality data results collected from the San Joaquin River, Calif., during Synoptic III (September 2008).

Appendix 8. Water-quality data results collected from the San Joaquin River, Calif., during Synoptic IV (June 2009). 
Prepared by the Sacramento Publishing Service Center.

For more information concerning this report, contact:

Director

U.S. Geological Survey

California Water Science Center

6000 J Street, Placer Hall

Sacramento, CA 95819

dc_ca@usgs.gov

or visit our Web site at:

http://ca.water.usgs.gov 


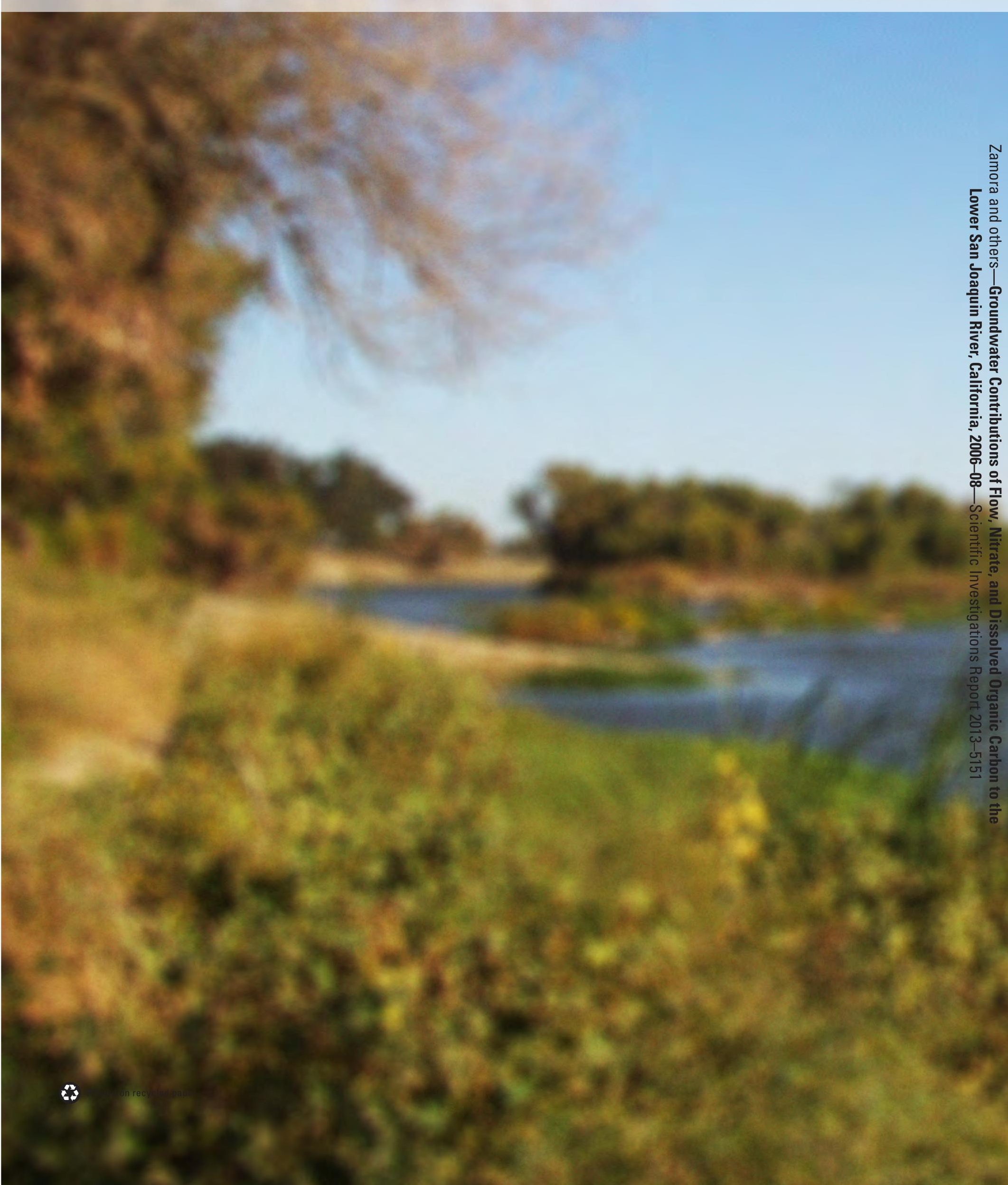

